\title{
Às margens do Elevado: a produção do espaço no Minhocão entre o virtual e o concreto
}

\section{Guido D’Elia Otero}

Orientadora:

Maria Beatriz Cruz Rufino

São Paulo 2020 


\section{Às margens do Elevado: a produção do espaço no Minhocão entre o virtual e o concreto}

versão corrigida

Dissertação apresentada para obtenção do título de Mestre no Programa de Pós-Graduação em Arquitetura e Urbanismo da Faculdade de Arquitetura e Urbanismo da Universidade de São

Paulo na área de concentração de Planejamento urbano e regional

Aluno:

Guido D’Elia Otero

Orientadora:

Maria Beatriz Cruz Rufino 
Este exemplar foi revisado e alterado em relação à versão original, sob responsabilidade única do autor e com a anuência de seu orientador. A versão original, em formato digital, ficará arquivada na Biblioteca da Faculdade de Arquitetura e Urbanismo da Universidade de São Paulo (FAU USP).

São Paulo, 23 de julho de 2020

Autorizo a reprodução e divulgação total ou parcial deste trabalho, por qualquer meio convencional ou eletrônico, para fins de estudo e pesquisa desde que citada a fonte.

email do autor: guido.otero@gmail.com

Catalogação na Publicação

Serviço Técnico de Biblioteca

Faculdade de Arquitetura e Urbanismo da Universidade de São Paulo

Otero, Guido

Às margens do Elevado: a produção do espaço no entorno do Minhocão entre o virtual e o concreto / Guido Otero; orientadora Maria Beatriz Cruz Rufino - São Paulo, 2020.

$290 p$.

Dissertação (Mestrado) - Faculdade de Arquitetura e Urbanismo da Universidade de São Paulo. Área de concentração: Planejamento Urbano e Regional.

1. Produção do espaço. 2. Renovação Urbana. 3. Capitalização. 4. Planejamento Urbano. 5. Produção imobiliária. I. Rufino, Beatriz, orient. II. Título.

Elaborada eletronicamente através do formulário disponível em: <http://www.fau.usp.br/fichacatalografica/> 
a Mariana e

Roberto 


\section{Agradecimentos}

À professora Maria Beatriz Cruz Rufino (Bia), pela orientação, dedicação e pelas inúmeras e animadoras conversas ao longo destes anos de intenso aprendizado.

Ao grupo de estudos e orientandos da Bia, pela troca e pelo apoio, em especial a Isadora Borges, Pia Carmagnani e o Victor Iacovini.

Ao Eduardo Nobre e Guilherme Petrella, pelas contribuições na banca de qualificação.

A todos os entrevistados para este trabalho: André Czitron, Francisco Gomes Machado Maxime Barkatz e Nabil Bonduki.

Ao Rafael Mielnik, pela contínua troca de material e a Maira Fernandes; a ambos pela ajuda nos gráficos, pela amizade, pelas discussões e por tudo mais.

À equipe do Lab Cidade, especialmente a Paula Santoro pela troca constante, a Aluízio Marino pelas aulas de Gis, a Debora Ungaretti e e Marina Harkot.

À gestão do IAB (2017-2019), pela oportunidade, troca e o imenso aprendizado, em especial ao Fernando Tulio e a Simone Gatti.

À equipe GOAA, pela continuação dos trabalhos na minha ausência, em especial ao Ricardo Gusmão pelo apoio fundamental e troca ao longo de toda a dissertação. 
Ao Marcio Moreto, do Monitor do Debate Político do Meio Digital, pelo material necessário para realizar o gráfico que trata do número de interações a partir de uma determinada notícia.

A Bia Falleiros, Cadu Marino e Carol Sacconi, pela diagramação, imagens e formatação deste trabalho, pelo carinho, paciência e suporte.

A Malena D’Elia Otero, pelas correções e apoio neste e em todos os trabalhos, e aos meus pais Mariana e Roberto. Aos três pelo afeto e suporte incondicional desde sempre.

A Juliana Coelho, pela correção, pela paciência, pelo incentivo, pelas discussões, pelo amor e pelas estrelas, que servem para iluminar este e outros trabalhos. 


\section{Resumo}

\section{Às margens do Elevado: a produção do espaço no Minhocão entre o virtual e o concreto}

O objetivo principal desta dissertação é analisar o imbricamento entre anúncios de projetos realizados pelo poder público e processos de transformação do espaço em áreas centrais da metrópole, com base no estudo de caso do Minhocão. São analisados como espaços antes ditos "degradados" ou "desvalorizados" são transformados em "fronteiras de expansão da lucratividade" (Smith, 2007) ou "fronteiras infernais da renovação urbana” (Petrella, 2017). A hipótese levantada é que as leis, planos e projetos públicos para o Minhocão mais do que intervir efetivamente no espaço, impulsionam a renovação urbana por meio da produção de uma imagem (virtual) que é apropriada pelos agentes privados que transformam o espaço de forma anárquica. $O$ projeto público se efetiva, portanto, na forma de um consenso a favor da transformação do espaço, que contribui para a (re)mercantilização da propriedade às margens da estrutura, alavancando a formação de capital fictício em um momento de deslocamento do regime de acumulação fordista para o de acumulação patrimonial (Lencioni, 2015).

Em síntese no trabalho discutimos por um lado os projetos anunciados pelo poder público, horizonte de desejos institucionalizados, e a formação de uma rede de agentes que pautam a transformação desta estrutura na esfera pública. Por outro lado, 
a produção concreta do espaço: o perfil dos novos negócios imobiliários, como eles gradualmente transformam o espaço e as disputas que se travam neste contexto, de modo a iluminar como as injustiças sociais são reproduzidas por meio da atividade imobiliária. A dissertação se divide em três capítulos: o primeiro que trata das determinações históricas do objeto de estudo, o segundo que trata da construção de uma imagem virtual e por último o terceiro que trata da produção concreta do espaço nesta região.

Palavras chaves:

1. Disputa pela produção do espaço; 2. renovação urbana; 3. capitalização; 4. planejamento urbano; 5. produção imobiliária.

Como citar:

OTERO, Guido D Elia. Às margens do Elevado: a produção do espaço no Minhocão entre o virtual e o concreto. Dissertação (Mestrado em Planejamento Urbano e Regional) - Faculdade de Arquitetura e Urbanismo da Universidade de São Paulo. São Paulo, 2020. 


\section{Abstract}

\section{On the margins of the Elevated: the production of space in Minhocão between the virtual and the concrete.}

The main objective of this work is to analyse the relation between public projects announcements and concrete space transformations in central areas of the metropolis, based on Minhocão's case study. We essay how spaces so called "degradated" or "undervalued" arise as "urban frontier / frontier of profitability" (Smith, 2007) or as "the infernal frontier of urban renewal" (Petrella, 2017). The hypothesis is that laws, plans and projects for Minhocão, instead of actually intervene in the space, shift the urban renewal by producing a virtual image that is appropriated by private agents that anarchically transform the space. The public projects are realized in the form of a consensus for the space transformation. This process contributes for a (re)commodification of the land in its surrounding properties and the shifting of fictional capital, in a moment of displacement from the fordist accumulation regime to a patrimony accumulation regime (Lencioni, 2015).

In synthesis, we discuss on one hand the public interventions projects, institutionalized horizons of desires, and the constitution of a pool of agents that guide the transformation of the structure in the public sphere. On the other hand, the concrete production of the space: the profile of the new real estate business, how they gradually transforms the surrounding 
space and the disputes that emerges in this context, aiming to illuminate the reproduction of social injustices. This dissertation is divided in three chapters: the first, about historical determination of the object of study; the second, about the construction of its virtual image and the last one, about the concrete space production in this region.

Keywords:

1.Dispute over space production; 2 . urban renovation; 3 . rent ground capitalization; 4. urban planning; 5.real estate. 


\section{Resumen}

\section{En las márgenes del Elevado: la producción del espacio en el Minhocão entre lo virtual y lo concreto.}

El objetivo principal de esta disertación es analizar la relación entre anuncios de proyectos realizados por el poder público y procesos de transformación del espacio en áreas centrales de la metrópolis, con base en el estudio de caso del Minhocão. Son analizados como espacios llamados "degradados" o "desvalorizados" son transformados en "fronteras de expansión del lucro" (Smith, 2007) o "fronteras infernales de la renovación urbana" (Petrella, 2017). La hipótesis trabajada es que las leyes, planes y proyectos públicos para el Minhocão más que intervenir efectivamente en el espacio, estimulan la renovación urbana por medio de la producción de una imagen (virtual) que es apropiada por los agentes privados que transforman el espacio de forma anárquica. El proyecto público se lleva a cabo, por lo tanto, en la forma de un consenso a favor de la transformación del espacio, que contribuye para la (re)mercantilización de la propiedad al margen de la estructura, catapultando la formación de capital ficticio en un momento de traspaso del régimen de acumulación fordista para el de acumulación patrimonial (Lencioni, 2015).

En síntesis, en el trabajo discutimos por un lado los proyectos anunciados por el poder público, horizonte de deseos institucionalizados, y la formación de una red de agentes que pautan la transformación de esta estructura en la esfera pública. Por otro 
lado, la producción concreta del espacio: el perfil de los nuevos negocios inmobiliarios, como ellos gradualmente transforman el espacio y las disputas que se establecen en este contexto, de modo de iluminar como las injusticias sociales son producidas por medio de la actividad inmobiliaria. La disertación se divide en tres capítulos: el primero que trata de la determinaciones históricas del objeto de estudio, el segundo que trata de la construcción de una imagen virtual y el tercero que trata de la producción concreta del espacio en esta región.

Palabras clave:

1. Disputa por la producción del espacio, 2. renovación urbana; 3. capitalización; 4. planeamiento urbano; 5. producción inmobiliaria. 


\title{
Siglas e abreviaturas
}

\author{
AEL - Área de Estruturação Local \\ AIU - Áreas de Intervenção Urbana \\ BNH - Banco Nacional de Habitação \\ BNI - Banco Nacional Imobiliário \\ BOVESPA - Bolsa de Valores de São Paulo \\ CA - Coeficiente de Aproveitamento do Terreno \\ CAe - Coeficiente de Aproveitamento do Terreno Efetivo \\ CAm - Coeficiente de Aproveitamento do Terreno Máximo \\ CEO - Chief Executive Officer (Diretor Executivo) \\ $\mathrm{CCl}$ - Cédula de Crédito Imobiliário \\ CEPAC - Certificado de Potencial Adicional de Construção \\ CMSP - Câmara Municipal de São Paulo \\ CONSEG - Conselho de Segurança \\ CRI - Certificado de Recebíveis Imobiliários \\ CTLU - Câmara Técnica de Legislação Urbanística \\ EMBRAESP - Empresa Brasileira de Estudos de Patrimônio \\ FAR - Fundo de Arrendamento Residencial \\ FGTS - Fundo de Garantia do Tempo de Serviço \\ FHC - Fernando Henrique Cardoso \\ FII - Fundos de Investimento Imobiliário \\ FIP - Fundo de Investimento em Participações \\ FUNDURB - Fundo de Desenvolvimento Urbano \\ GEIA - Grupo Executivo da Indústria Automobilística \\ HIS - Habitação de Interesse Social \\ HMP - Habitação de Mercado Popular \\ IAB - Instituto dos Arquitetos do Brasil \\ IPO - Initial Public Offering \\ IPTU - Imposto sobre a Propriedade Predial e Territorial Urbana \\ ITDP - Institute for Transportation and Development Policy \\ JUCESP - Junta Comercial do Estado de São Paulo
}




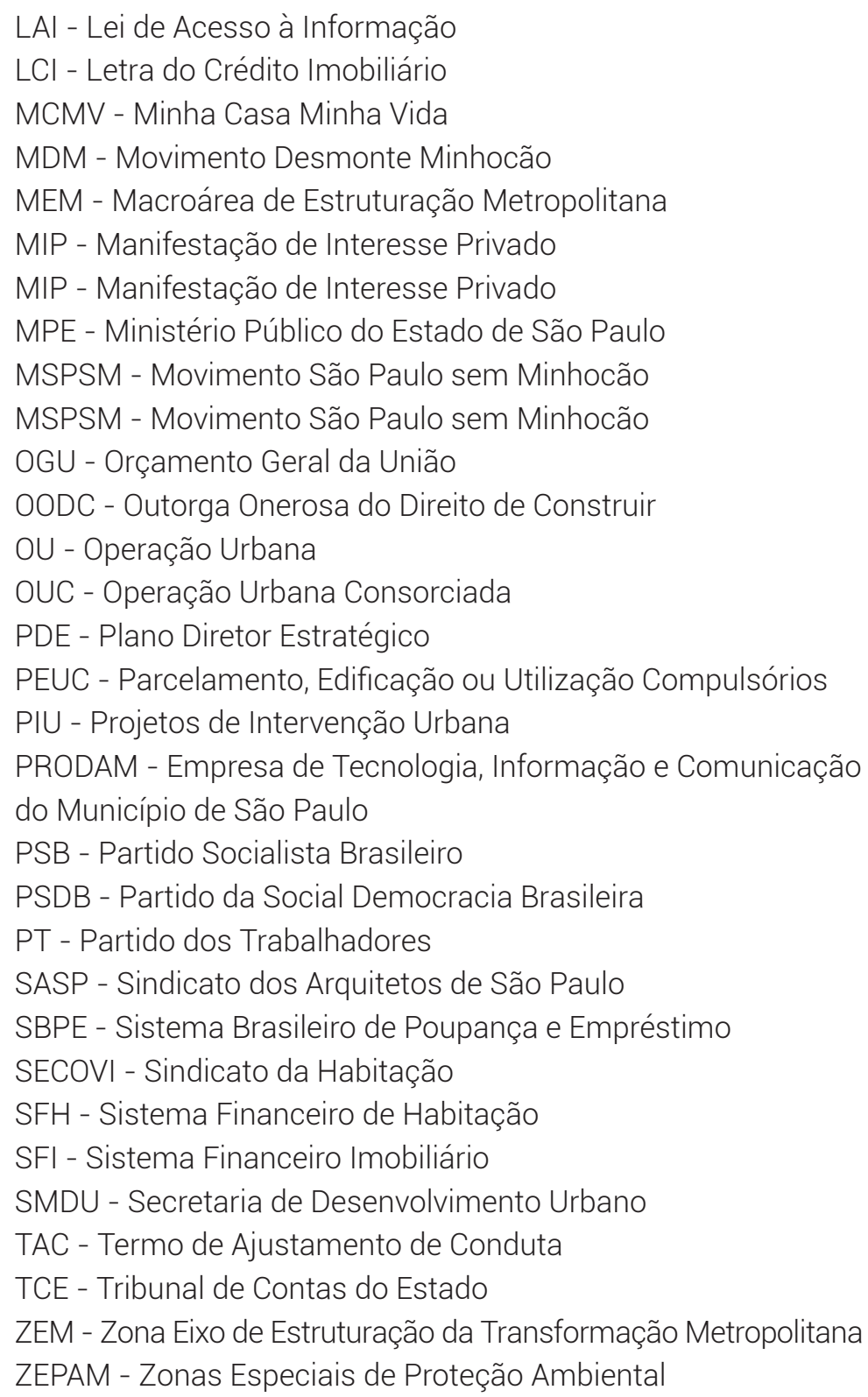




\section{Listas}

\section{Lista de tabelas}

\section{p. 14 Tabela 2.4.1}

Leis, planos e projetos para o Minhocão.

\section{Lista de gráficos}

p. 93 Gráf. 2.1.1

Arrecadação anual via OODC e CEPAC, nas Operações

Urbanas e no restante da cidade.

p. 146 Gráf. 2.4.1

Evolução das buscas dos termos "Parque Minhocão" e "Desmonte Minhocão" na plataforma Google trends.

p. 146 Gráf. 2.4.2

Interações a partir da notícia publicada na Revista Veja São Paulo.

p. 160 Gráf. 3.1.1

Evolução dos preços de locação e compra MSP em porcentagem.

p. 180 Gráf. 3.2.1

Lançamentos por ano ZEM Minhocão.

p. 180 Gráf. 3.2.2

Número de unidades lançadas por ano ZEM Minhocão.

p. 183 Gráf. 3.2.3

Evolução número de unidades lançadas RMSP, Centro e ZEM Minhocão.

p. 187 Gráf. 3.2.4

Evolução da área útil média das unidades lançadas por ano RMSP.

p. 188 Gráf. 3.2.5

Evolucão da área média dos terrenos utilizados por ano. 
p. 189 Gráf. 3.2.6

Evolucão do coeficiente de aproveitamento efetivo (CAe) RMSP.

p. 190 Gráf. 3.2.7

Evolução dos lançamentos no Centro (dist. Sé e República).

p. 191 Gráf. 3.2.8

Evolucão do número médio de vagas por unidade hab. lançada RMSP.

p. 224 Gráf. 3.2.9

Evolução do preço por m² de área útil mín. e máx. na RMSP e médio na ZEM Minhocão.

p. 225 Gráf. 3.2.10

Evolução do preço por $\mathrm{m}^{2}$ de área útil mín.e máx. nos bairros do entorno e médio na ZEM Minhocão.

p. 226 Gráf. 3.2.11

Evolução do VGV dos empreendimentos na ZEM Minhocão (valores atualizados para 2018).

p. 230 Gráf. 3.3.1

Número de novos estabelecimentos hipsters na Vila Buarque.

p. 236 Gráf. 3.3.2

Evolução área construída e lotes ocupados MSP.

p. 236 Gráf. 3.3.3

Evolução área construída e lotes ocupados por usos industriais MSP.

p. 236 Gráf. 3.3.4

Evolução lotes ocupados por terrenos vagos MSP.

p. 237 Gráf. 3.3.5

Área construída por tipos de uso na ZEM Minhocão (1995).

p. 237 Gráf. 3.3.6

Área construída por tipos de uso na ZEM Minhocão (2019).

p. 238 Gráf. 3.3.7

Evolução áreas construídas e lotes ocupados por uso residencial horizontal baixo padrão na ZEM Minhocão.

p. 239 Gráf. 3.3.8

Evolução áreas construídas e lotes ocupados por uso residencial vertical baixo padrão na ZEM Minhocão.

p. 238 Gráf. 3.3.9

Evolução áreas construídas e lotes ocupados por uso residencial horizontal médio padrão na ZEM Minhocão. 
p. 239 Gráf. 3.3.10

Evolução áreas construídas e lotes ocupados por uso residencial vertical médio padrão na ZEM Minhocão.

p. 238 Gráf. 3.3.11

Evolução áreas construídas e lotes ocupados por uso residencial horizontal alto padrão na ZEM Minhocão.

p. 239 Gráf. 3.3.12

Evolução áreas construídas e lotes ocupados por uso residencial vertical alto padrão na ZEM Minhocão.

p. 240 Gráf. 3.3.13

Evolução lotes ocupados por terrenos vagos na ZEM Minhocão.

p. 240 Gráf. 3.3.14

Evolução áreas construídas e lotes ocupados por uso de garagens na ZEM Minhocão.

\section{Lista de figuras}

p. 43 Fig. 1.1.1

Plano de Avenidas da Cidade de São Paulo.

p. 46 Fig. 1.1.2

Anúncio de terreno à venda.

p. 46 Fig. 1.1.3

Fotografia da Av. General Olímpio da Silveira.

p. 47 Fig. 1.1.4

Fotografia da Praça Marechal Deodoro.

p. 48 Fig. 1.1.5

Fotografia da Av. São João.

p. 49 Fig. 1.1.6

Fotografia aérea da Av. São João.

p. 52 Fig. 1.2.1

Ilustração da proposta Lower Manhattan Expressway.

p. 54 Fig, 1.2.2.

Fotografia interna do pavilhão Futurama: Highways and Horizons.

p. 56 Fig, 1.2.3

Fotografia da construção do Elevado Costa e Silva. 

p. 57 Fig, 1.2.4
Fotografia da construção do Elevado Costa e Silva.
p. $58 \quad$ Fig $\mathbf{1 . 2 . 5}$
Convite para inauguração do Elevado Costa e Silva.
p. 59 Fig, 1.2.6
Fotografia do Pref. Paulo Maluf na inauguração do Elevado.
p. $60 \quad$ Fig 1.2.7
Anúncio publicitário da empresa Hidroservice.
p. $62 \quad$ Fig 1.2.8

Anúncio publicitário da empresa Mangels.

p. 63 Fig 1.2.9

Anúncio publicitário da empresa Sabrico.

p. $77 \quad$ Fig. 1.3.1

Notícia "Minhocão aberto para carrinho de bebê".

p. 78 Fig. $\mathbf{1 . 3 . 2}$

Fotografia Festival Baixo Centro.

p. $91 \quad$ Fig. 2.1.1

Macroárea de Estruturação Metropolitana (MEM) do Plano Diretor de São Paulo, 2002.

p. $91 \quad$ Fig. 2.1.2

Macroárea de Estruturação Metropolitana (MEM) do Plano Diretor de São Paulo, 2014.

p. $96 \quad$ Fig. 2.1.3

Ilustração das Diretrizes para o Ordenamento da Paisagem no PDE de 2014.

p. 99 Fig. 2.1.4

Aumento de preços dos imóveis no entorno do High Line de Nova York.

p. 115 Fig. 2.2.1

Fotografia dos vereadores Nabil Bonduki, Police Neto e Ricardo Young.

p. 117 Fig. 2.2.2

Divulgação de Caio Miranda Carneiro da audiência pública do PL n. 98/2018 pelo desmonte do Minhocão.

p. 119 Fig. 2.2 .3

Material de campanha do Vereador Camilo Cristófaro.

p. $133 \quad$ Fig. 2.3.1

Eixo de Transformação Elevado Presidente João Goulart, apresentado na CTLU pelo PIU Setor Central. 
p. 135 Fig. 2.3.2

Ilustração "Portais de São Paulo" do escritório de arquitetura Jaime Lerner sobre o projeto "Centro Novo".

p. 135 Fig. 2.3.3

|lustração do projeto "Parque Minhocão" do escritório de arquitetura Jaime Lerner.

p. 137 Fig. 2.3.4

llustração de sombreamento do projeto "Parque Minhocão" do escritório de arquitetura Jaime Lerner.

p. 137 Fig. 2.3 .5

|lustração de veículo elétrico do projeto "Parque Minhocão" do escritório de arquitetura Jaime Lerner.

p. 137 Fig. 2.3.6

Ilustração de espaços publicitários do projeto "Parque Minhocão" do escritório de arquitetura Jaime Lerner.

p. 143 Fig. 2.3.7

Foto aérea do Minhocão.

p. 147 Fig. 2.4.1

Postagem no perfil da Prefeitura de São Paulo sobre a criação do Parque Minhocão.

p. 150 Fig. $\mathbf{2 . 4 . 2}$

Fotografia do Minhocão no início da década de 1970.

p. 151 Fig. 2.4.3

Campanha criada pela WMcCann para a Chevrolet, com colaboração da PBA Cinema e da Triptyque Architecture.

p. 161 Fig. 3.1.1

Gradiente de preços de terrenos vazios ofertados na RMSP.

p. 186 Fig. 3.2.1

Anúncio publicitário do empreendimento "Studio".

p. 196 Fig. 3.2.2

Capa da página web da empresa llion Partners.

p. 197 Fig. $\mathbf{3 . 2 . 3}$

Imagem de divulgação do Ed. Marajó (esquerda) e Juliana Torres (direita).

p. 198 Fig. 3.2.4

Plantas de divulgação das unidades do empreendimento Uliving 433. 
p. $199 \quad$ Fig. $\mathbf{3 . 2 . 5}$

Fotografia de ação para divulgação do Empreendimento Juliana Torres.

p. 202 Fig. 3.2.6

Imagem de divulgação do Emp. Setin Downtown São João.

p. 202 Fig. 3.2.7

Imagem de divulgação do Emp. Setin Downtown Nova República e República.

p. 206 Fig. 3.2.8

Imagem de divulgação da unidade do Emp. Cosmopolitan Santa Cecília.

p. $206 \quad$ Fig. $\mathbf{3 . 2 . 9}$

Imagem de divulgação do empreendimento Cosmopolitan Santa Cecília.

p. 207 Fig. 3.2.10

Fotografia do Empreendimento Helbor Trend Higienópolis.

p. 209 Fig. 3.2.11

Notícia "Van e horta entram na conta do condimínio" Folha de S. Paulo.

p. $210 \quad$ Fig. 3.2.12

Captura de vídeo de divulgação do empreendimento Smart Santa Cecília.

p. 212 Fig. 3.2.13

Imagem de divulgação do empreendimento VN Nova Higienópolis.

p. 212 Fig. 3.2.14

Divulgação da plataforma Housi da empresa Vitacon.

p. 213 Fig. $\mathbf{3 . 2 . 1 5}$

Imagem de divulgação do empreendimento Link Residencial Saúde.

p. 213 Fig. 3.2.16

Imagem de divulgação do empreendimento On Melo Alves.

p. $214 \quad$ Fig. 3.2.17

Postagem no perfil do Instagram da Vitacon.

p. 215 Fig. 3.2.18

Imagem de divulgação do Emp. Bem Viver Marquês de Itu.

p. 215 Fig. 3.2.19

Imagem de divulgação do Emp. Bem Viver General Jardim. 
p. 216 Fig. 3.2.20

Imagem de divulgação da unidade do Emp. Bem Viver General Jardim.

p. 217 Fig. 3.2.21

Imagem do Instagram do stand de vendas do Emp. Bem Viver Marquês de Itu.

p. 217 Fig. 3.2.22

Imagem do Instagram do stand de vendas do Emp. Bem Viver Marquês de Itu.

p. 220 Fig. 3.2.23

Fotografia placa de obras Emp. Living for Cosolação.

p. 220 Fig. 3.2.24

Imagem de divulgação do empreendimento Living for Consolação.

p. 222 Fig. 3.2.25

Imagem de divulgação de unidade do Emp. Share Student Living Consolação.

p. 222 Fig. 3.2.26

Imagem de divulgação de unidade do Emp. Share Student Living Consolação.

p. 222 Fig. 3.2.27

Imagem de divulgação de unidade do Emp. Share Student Living Consolação.

p. 231 Fig. 3.3.1

Localização dos empreendimentos hipsters.

p. 234 Fig. 3.3.2

|lustração "Mapeamento afetivo Região Central de São

Paulo".

p. 244 Fig. 3.3.3

Apartamentos à venda de frente para o Elevado.

Foto: Gyovana Freire, 2019.

p. 253 Fig. 3.3.4

Fotografia Al. Ribeiro da Silva, 797 (2010).

p. 253 Fig. 3.3.5

Fotografia Al. Ribeiro da Silva, 797 (2018).

p. 254 Fig. 3.3.6

Fotografia Alameda Glete, 1058 (2010).

p. 255 Fig. 3.3.7

Fotografia Alameda Glete, 1058 (2018). 

p. $254 \quad$ Fig. 3.3 .8
Fotografia Avenida Angélica, 41 (2010).
p. 255 Fig. 3.3.9
Fotografia Avenida Angélica, 41 (2018).
p. 254 Fig. 3.3.10
Fotografia Rua Albuquerque Lins, 350 (2010).
p. $255 \quad$ Fig. 3.3.11
Fotografia Rua Albuquerque Lins, 350 (2018).
p. $256 \quad$ Fig. 3.3.12
Fotografia Rua Barão de Campinas, 573 (2010).
p. 257 Fig. 3.3.13
Fotografia Rua Barão de Campinas, 573 (2018).
p. $256 \quad$ Fig. 3.3.14
Fotografia Rua Barão de Tatuí, 234 (2010).

p. $257 \quad$ Fig. 3.3.15

Fotografia Rua Barão de Tatuí, 234 (2017).

p. 256 Fig. 3.3.16

Fotografia Rua GeneraL Julio Marcondes Salgado, 115 (2010).

p. 257 Fig. 3.3.17

Fotografia Rua GeneraL Julio Marcondes Salgado, 115 (2017).

p. $260 \quad$ Fig. 3.3.18

Processos de desapropriação, reintegração de posse e ocupações irregulares.

p. $261 \quad$ Fig. 3.3.19

Mapa de referências culturais do Inventário Participativo Minhocão contra gentrificação.

\section{Lista de mapas}

p. 86 Mapa 2.1.1

Territorialização das notificações do não cumprimento da Função Social da Propriedade.

p. 184 Mapa 3.2.1

Lançamentos na ZEM Minhocão entre 1985 e 2018.

p. 200 Mapa 3.2.2

Lançamentos na ZEM Minhocão a partir de 2010.

p. 204 Mapa 3.2.3

Localização dos empreeendimentos da incorporadora You, Inc . 


\section{p. 246 Mapa 3.3.1}

Rendimento nominal mensal médio por domicílio permanente (em salários-mínimos).

\section{p. 247 Mapa 3.3.2}

Rendimento nominal mensal médio do responável pelo domicílio (em salários-mínimos).

p. 248 Mapa 3.3.3

Porcentagem de pessoas residentes de cor preta e parda por setor censitário.

p. 250 Mapa 3.3.4

Localização de cortiços (2006) e da população em situação de rua (2009/2015).

\section{p. 252 Mapa 3.3.5}

Localização de cortiços (2006) e abordagens Operação Baixas Temperaturas (2017). 


\section{Sumário}

p. 27 Introdução

p. 33 Capítulo 1: A construção do Elevado Costa e Silva como síntese das transformações urbano-imobiliárias da metrópole do século $X X$

p. 35 1.1. A Avenida São João: a fervilhante Cinelândia paulistana e a intensificação da construção

p. 50 1.2. A construção do Elevado Costa e Silva: a cidade para o automóvel e a "generalização" da produção imobiliária intensificada

p. 67 1.3. O Minhocão e o centro da cidade na virada do século XX: novas formas de apropriação do espaço

p. 81 Capítulo 2: Estratégias para a transformação da cidade e do Minhocão: (des)regulamentação e impulsos virtuais

p. 83 2.1. Novos marcos regulatórios das políticas urbanas no Brasil e a sucessão de Planos Diretores de São Paulo no século XXI

p. 103 2.2. A construção dos discursos em torno da transformação do Minhocão:

as organizações da sociedade civil e os vereadores

p. 122 2.3. Leis, planos e projetos para o Minhocão: entre o discurso e a intervenção efetiva

p. 144 2.4. Impulsos virtuais 
p. 153 Capítulo 3: Produção do espaço e renovação da propriedade imobiliária no entorno do Minhocão: a produção concreta da cidade

p. 156 3.1. Notas sobre a produção do espaço no Brasil do século XXI: novos marcos regulatórios para a produção imobiliária

p. 179 3.2. A produção imobiliária para mercado no entorno do Minhocão

p. 227 3.3. Impulsos e limites para a (re)capitalização da propriedade imobiliária: novas e antigas formas de uso do espaço

p. 265 Considerações finais

p. 271 Bibliografia 


\section{Introdução}

Esta dissertação trata da produção do espaço recente no entorno do Minhocão e sua relação com as leis, os planos e projetos promulgados pelo poder público ao longo do século XXI que visam a transformação desta estrutura.

Construída durante o ano de 1970 e inaugurada no dia 25 de janeiro de 1971, a via expressa exclusiva para o transporte de veículos motorizados, batizada na época de Elevado Costa e Silva, foi concebida como parte integrante de um complexo viário que interliga, até os dias de hoje, a Zona Leste à Zona Oeste de São Paulo, cruzando o centro da cidade. Caracterizada como uma via elevada de mão dupla construída em concreto armado, a via recebeu o apelido de Minhocão pela sua longa extensão (2,8 km) e seu desdobramento sinuoso sobre a malha urbana, serpenteando sobre as avenidas Francisco Matarazzo, General Olímpio da Silveira, São João e a rua Amaral Gurgel para interligar o Largo Padre Péricles, em Perdizes, à Praça Roosevelt, próximo ao cen- 
tro histórico da cidade. Ao longo do tempo, o Elevado recebeu diversos nomes e apelidos, assim como diversas leituras sobre seu impacto no entorno. Recentemente, foi renomeado Elevado João Goulart e, em certos horários, Parque Minhocão. Para nos referirmos a esta via expressa elevada, usaremos, ao longo do trabalho, as denominações Minhocão ou Elevado.

Dois meses antes da sua inauguração, em dezembro de 1970, o jornal O Estado de São Paulo denunciava o esvaziamento que sua obra tinha desencadeado nos imóveis localizados no seu entorno e as consequências trazidas por esse tipo de intervenção em outras cidades do mundo: "todo o submundo do crime e da prostituição, das populações marginalizadas reunido sob o agasalho de cimento do imenso viaduto" (O Estado de S. Paulo, 1970). O impacto foi lido imediatamente como drástico e, consequentemente, em 1975, a via passou a ser fechada para os automóveis entre as $0 \mathrm{~h}$ e $5 \mathrm{~h}$ da manhã, buscando melhorar o conforto daqueles que habitam os apartamentos contíguos à via elevada, por vezes localizados a uma distância de $5 \mathrm{~m}$ do seu leito carroçável.

Ao longo dos anos, os imóveis ali localizados, desvalorizados pelas péssimas condições ambientais e rejeitados pelo mercado de classe média e média-alta se transformaram em moradia acessível para as classes de menor renda. Processo verificado também em outros centros metropolitanos que, abandonados pelas classes dominantes e pelas administrações públicas, passam por um movimento de "popularização" (Kara José, 2010).

Recentemente, no entanto, o Minhocão passou a ser personagem de uma trama urbana diferente daquela que gestou a sua construção. Ao longo dos anos, o fechamento da via para o transporte permitiu que nesses horários, abertos apenas para o fluxo de pedestres e ciclistas, a via fosse ocupada para atividades de lazer variadas, diferentes do mero deslocamento de passageiros entre trabalho e residência para o qual foi concebido.

Nesta nova trama um crescente número de agentes tem se articulado para ressignificar o impacto desta estrutura e propor soluções 
para equacionar a sua implantação no tecido urbano. A partir do século XXI uma série de leis, planos e projetos divulgados pelo poder público contribuíram para que a transformação da via expressa se tornasse uma pauta reconhecida publicamente. Este processo culminou, em 2019, no início dos estudos do Projeto de Intervenção Urbana (PIU) Parque Minhocão, que visa a transformação da estrutura num espaço de lazer da cidade.

Ao longo de todo o período estudado, verificamos que o mercado imobiliário não cessou de realizar lançamentos no entorno do Minhocão, por isso o entendimento de que a estrutura teria acarretado um arrefecimento da produção aqui se torna um artifício cujos fins discutiremos ao longo do trabalho. O que mudou, além de toda uma reestruturação do mercado imobiliário, foi a localização e intensificação desta produção, agora ocupando as porções do Elevado mais próximas da região central. Este movimento se relaciona tanto a novos paradigmas urbanos quanto às mudanças dos axiomas que regem a acumulação capitalista, deslocamento mais amplo no qual a propriedade ganha centralidade.

Entendemos, neste sentido, que existe de um lado uma cidade construída em termos virtuais, horizontes de desejos institucionalizados por meio de projetos divulgados pelo poder público, virtualidades impulsionadas por agentes que se articulam em torno de um consenso: a transformação do espaço. De outro, a produção concreta do espaço, um produto socialmente produzido, em torno do qual se travam disputas e exacerbam-se as contradições do atual modo de produção capitalista. O objeto deste trabalho se enquadra na fricção destas duas facetas do espaço social: uma virtual e a outra concreta.

Buscamos, portanto, analisar o imbricamento entre anúncios de projetos realizados pelo poder público e processos de transformação do espaço em áreas centrais da metrópole com base no estudo de caso do Minhocão e seu entorno. São analisados como espaços antes ditos "degradados" ou "desvalorizados" são transformados em "fronteiras de expansão da lucratividade" (Smith, 2007) ou "fronteiras infernais da renovação urbana" (Petrella, 2017). 
A hipótese que levantamos é que as leis, os planos e projetos, mais do que intervir efetivamente no espaço, contribuem na construção de uma imagem (virtual) apropriável pelos agentes privados que com poderes monopolísticos transformam o espaço de forma anárquica. $O$ projeto público não realiza um programa de intervenções como em projetos urbanos anteriores, mas se realiza na forma de um consenso pela transformação do espaço.

A dissertação se divide em três capítulos: o primeiro que trata das determinações históricas do objeto de estudo, o segundo que trata da construção desta imagem virtual e por último um capítulo que trata da produção concreta do espaço.

No primeiro capítulo, fazemos uma recuperação histórica das transformações na região do Minhocão ao longo do século XX, buscando elucidar através de breves anotações mudanças na produção imobiliária associada a novos paradigmas urbanos. Dividido em três itens, discutimos inicialmente a constituição da Av. São João e sua importância na estruturação de um eixo de intensa atividade imobiliária e comercial sentido oeste da colina histórica. Em seguida, contextualizamos a construção do Elevado Costa e Silva no cerne do projeto desenvolvimentista autoritário pautado na industrialização e na consagração do automóvel. Por último, discutimos as transformações recentes no uso desta estrutura, associadas à redemocratização do País, discutindo como a década de 1990 se constituiu num período de transição com o século XXI relevante para nossos estudos. Para cada um destes momentos, levantamos os paradigmas de cidade, dos quais estes projetos ao mesmo tempo se nutrem e ajudam a construir: arquiteturas e arquitetos que desenham cidades compatíveis com os deslocamentos das formas de produção, valorização e acumulação.

No segundo capítulo, centramos os estudos na construção de um consenso que impulsiona a transformação da região que aqui chamamos de espaço da virtualidade. Analisamos por um lado os projetos de lei e planos tanto para a cidade de São Paulo quanto para o Minhocão e por outro os setores da sociedade que encabeçam o debate sobre o futuro desta estrutura. No primeiro 
item, analisamos de forma mais ampla os dois Planos Diretores para a cidade de São Paulo, promulgados no começo do século XXI, principalmente no que tange às transformações propostas para a região na qual o Elevado está inserido. Entendemos que estes Planos, enquanto pacto entre as múltiplas partes, são fundamentais na institucionalização de um horizonte de desejos que norteiam certa produção do espaço na cidade. Na sequência levantamos as organizações da sociedade civil envolvidas no debate sobre a transformação do Minhocão e como elas se articulam a vereadores para dar andamento, na instância legislativa, às suas pauta. Finalmente analisamos as leis, os planos e projetos que foram elaborados ou apenas anunciados pelo poder público para o Elevado, constituintes deste espaço virtual.

No último capítulo, nos debruçamos sobre as transformações concretas no entorno do Elevado principalmente ao longo do século XXI. Discutimos a produção imobiliária para mercado, como ela gradualmente transforma o espaço e as disputas que se travam neste contexto, de modo a compreender como as injustiças sociais são reproduzidas por esta atividade. No primeiro item, buscamos enquadrar por um lado em termos teóricos e de forma ampla a especificidade da mercadoria imobiliária, a sua precificação e, consequentemente, como se realiza a sua valorização ${ }^{1}$ e por outro os marcos que regulam esta atividade no Brasil. No segundo item, nos debruçamos sobre os lançamentos imobiliários de edifícios residenciais no entorno do Minhocão, tecendo comparações com a produção no resto da metrópole. No último item, analisamos as transformações no espaço para além destes novos lançamentos e os limites que o avanço do setor encontra aqui, elencando como se dá aqui a disputa pelo espaço. Buscamos iluminar o caráter popular desta região para discutir, na sequência, como ele está gradualmente sendo transformado.

1. Nos referimos aqui ao termo 'valorização' na sua determinação mais vulgar, que trata da elevação do preço. 


\section{A construção do Elevado Costa e Silva como síntese das transformações urbano-imobiliárias da metrópole do século $X X$}

Neste item do primeiro capítulo, traçaremos de forma sucinta um panorama das mudanças no entorno do Minhocão ao longo do século XX, buscando fazer um paralelo com pontos importantes das transformações da metrópole. $\mathrm{O}$ texto se divide em três subitens: (i) momento anterior à construção do Minhocão; (ii) a própria construção do Elevado; (iii) momento posterior à construção.

No primeiro subitem, com base na revisão bibliográfica de autores que discutem os primórdios do planejamento urbano na cidade de São Paulo, procuramos entender a configuração da Avenida São João e dos seus arredores ao longo das primeiras décadas do século XX antes da construção do Minhocão. Destacam-se três momentos considerados fundantes para a conformação da região: (1) os loteamentos para a elite a oeste do Vale do Anhangabaú; (2) os planos de embelezamento e melhoramentos do começo do século; (3) o Plano de Avenidas 
de Prestes Maia, cujo segundo mandato na prefeitura de São Paulo antecedeu imediatamente o início dos projetos para o Elevado.

No segundo item, discutimos as mudanças na política urbana associadas à industrialização e ao advento do automóvel e os novos paradigmas que sustentaram a construção do Elevado Costa e Silva. Analisamos o processo de abandono do centro histórico da cidade tanto pelas camadas médias-altas e altas quanto pela administração pública, relegando-o a um processo de deterioração ambiental e esvaziamento populacional, que se estendeu ao longo de três décadas.

No último subitem, é analisado o novo perfil "popular" do centro da cidade após o seu esvaziamento e as primeiras iniciativas de "revitalizar" a região a partir da década de 1990. Finalmente, elencamos algumas novas formas de apropriação do centro, das quais o Minhocão se tornou um dos palcos mais emblemáticos, principalmente com a extensão do horário de fechamento para circulação de automóveis. 


\section{A Avenida São João: a fervilhante Cinelândia paulistana e a intensificação da construção}

A Avenida São João foi um eixo fundante da história do desenvolvimento da cidade de São Paulo tendo suas origens no caminho de tropeiros, que se estendia sentido Sorocaba e Jundiaí a partir da colina histórica. $\mathrm{Na}$ época da sua construção, a ponte do Acu, sobre o Rio Anhangabaú, foi uma das três principais pontes construídas em pedra da capital e constituiu o início deste importante eixo de desenvolvimento urbano, que se estende do centro histórico sentido oeste até os dias de hoje.

Beneficiada pelo próspero ciclo do café, a capital agroexportadora se transformou em um entreposto não apenas físico para as mercadorias que viajavam entre o Brasil e a Europa, mas também imagético. A infraestrutura necessária para amparar a produção cafeeira, principalmente a ferroviária, assim como a industrialização decorrente do café aproximaram a cidade de São Paulo dos capitais internacionais que, com a República encontram maior facilidade para desembarcar no País. Junto a eles, a Paris das grandes avenidas do Barão Haussmann seria o ícone partilhado entre a elite a ser importado. Podemos sintetizar, a importância do ciclo do café para a constituição da cidade de São Paulo, a partir de Brandão (2012), da seguinte maneira:

\footnotetext{
O café plantará cidades. Novas funções urbanas serão impostas pela acumulação cafeeira, que possui múltiplas faces (Mello, 1975; Cano, 1975): café, ferrovias, bancos, comercio, industria, infra-estrutura etc. Todas essas faces serão sintetizadas no espaço urbano, cada vez mais diferenciado e dinâmico (Brandão, 2012, 109).
} 
De acordo com o que aponta Toledo (1983, p. 55), desses anseios surgiriam, no final do século $\mathrm{XX}$, os primeiros bairros construídos para abrigar a elite cafeicultora, que começava a passar mais tempo na cidade para administrar a expansão dos seus negócios do que na fazenda. População que paulatinamente passou a consumir espaço nos loteamentos regulamentados pelas Lei de Terras de 1850 que permitirau "que empreendedores particulares loteassem chácaras" (Campos, 2008, p. 26), que compunham a estrutura fundiária dos arrabaldes em torno da colina histórica. Especificamente, alguns mascates seriam então pioneiros na construção de bairros para essa elite. Conforme descreve Toledo:

\footnotetext{
Glette e Nothmann compreendem todas essas aspirações. Adquirem a Chácara Mauá, no antigo Campo Redondo, e a dividem com ruas largas, bem mais largas que as do triângulo e com amplos lotes, que lembram as antigas chácaras. O nome evoca Paris: Campos Elísios (Toledo, 1983, p. 67).
}

Após o relativo sucesso deste primeiro loteamento exclusivo para as elites (Marins, 2011 apud Ferreira, 2016, p. 41), realizado em parceria com Frederico Glette, o mascate Victor Nothman se juntou ao também alemão Martinho Burchard para propor o chamado Boulevard Burchard, que viria posteriormente a compor o bairro de Higienópolis próximo à recém-aberta Vila Buarque. Os terrenos elevados a sudoeste garantiam aqui isolamento pleno de eventuais casas geminadas e galpões industriais que se misturavam perto da via férrea no loteamento de Campos Elíseos, garantindo exclusividade às classes mais abastadas. Conforme aponta Ferreira (2016) os terrenos comercializados no Boulevard Burchard propagandiavam locais altos e arejados na malha urbana, atendidos pelo serviço de bondes, água, gás e esgoto, além de uma ampla arborização. Viabilizados por bastos investimento em infraestrutura, eles procuravam atrair, segundo anúncio publicitário da época, aos "srs. capitalistas de bom gosto para um emprego de capital" (Ferreira, 2016, p. 45).

A cidade que começava a crescer intensamente conheceu então uma "epidemia" de loteamentos (Toledo, 1983, p. 67), surto que se beneficiou tanto do capital excedente do ciclo do café quanto 
da oferta de crédito via novos bancos ${ }^{1}$. No loteamento e arruamento de chácaras, demandados pela esta classe social capitalizada em busca da construção de um espaço de distinção na cidade, estes capitais encontraram um local propício para a sua reprodução. "Assim, uma a uma, as antigas chácaras, tão apreciadas pelos viajantes que por aqui passaram na primeira metade do século, começam a ser loteadas, de forma empírica e desordenada" (Toledo, 1983, p. 68).

Os loteamentos realizados a oeste do centro da cidade para a crescente elite cafeeira paulistana ajudaram a consolidar a Av. São João como eixo de expansão imobiliária e futuramente de intensa atividade comercial e cultural. Locais de descanso, afastados das precárias e estreitas ruas da colina histórica, da fervilhante fricção entre corpos associada ao centro da cidade, os novos loteamentos vinham acompanhados de outra novidade: os bondes elétricos, transporte coletivo que passou a articular os arredores da cidade ao Centro. Estes arejados loteamentos garantiram a estrutura fundiária, organizada em grandes lotes de um único proprietário e arruamentos largos e arborizados, que posteriormente seria facilmente aproveitada para realizar empreendimentos verticais para a mesma classe social.

A oferta de capitais associada ao fortalecimento da administração municipal ${ }^{2}$ e ao pujante crescimento da cidade ${ }^{3}$ criaram um cenário favorável para que capitais privados, famílias proprietárias de terras, se associassem eventualmente a legisladores na disputa em torno da criação e do desenho de novas frentes de melhoramentos urbanos. O palco primordial desta disputa se

1. Governo Provisório na transição para a República "permitiu a criação de bancos emissores e companhias por ações, com o objetivo de ativar o funcionamento da economia" (Glezer, 2007, p.171 apud D'Elboux, 2015, p. 240).

2. Na década de 1890 , foram criadas algumas instâncias administrativas relevantes para o fortalecimento da gestão municipal: em 1892, é constituída "pelo Regimento Interno da Câmara (Lei n.9 de 3/12/1892)" a Intendência de Obras Municipais, que em 1896 recebeu a tarefa de elaborar uma planta cadastral da cidade e em 1899 é criado o cargo para Prefeito (Toledo, 1996, p. 64).

3. "(...) a população urbana dobrou em cinco anos: em 1890, havia 65 mil habitantes, que passaram a 130 mil em 1895! Em 1900 a cidade contava com 240 mil habitantes $-84,6 \%$ de crescimento. Uma explosão demográfica de $269 \%$ na década, quase 14\% ao ano" (Glezer, 2007, p.169 apud D'Elboux, 2015, p. 230). 
encenou principalmente na área central "visando transformá-la em núcleo comercial e institucional à altura da riqueza proporcionada pelo café (Campos, 2008, p. 28). Para ilustrar este arranjo, D'Elboux (2015) utiliza o exemplo do Conde de Prates, cafeicultor dono de importantes fazendas produtoras de café e um dos maiores proprietários de terras no Vale do Anhangabaú:

A título de exemplo, veja-se o caso de um dos protagonistas do debate acerca dos Melhoramentos de São Paulo, nos anos 1910-1912. O Conde de Prates foi, ao longo da primeira década do século XX, ampliando e diversificando sua participação em companhias ligadas à economia cafeeira, direta ou indiretamente. Em uma rápida busca no Correio Paulistano, pode-se encontrar seu nome ligado às seguintes empresas: Companhia Frigorífica Paulista e Cooperativa Agrícola Comercial, como sóciofundador de ambas; Automóvel Clube Paulista, como vice-presidente; Companhia Geral de Armazéns Gerais, como diretor, embora também fosse um dos fundadores; Companhia Paulista de Seguros, como membro do conselho consultivo; A Economisadora Paulista, como membro do conselho fiscal da caixa de pensões; Companhia Paulista de Vias Férreas e Fluviais, como vice-presidente e mais tarde, presidente; Banco de S. Paulo, como vice-presidente; e ainda a Sociedade Hípica Paulista, como sóciofundador n. 1, denotando paixão por cavalos

Muitos dos nomes que aparecem neste texto, quer negociando terras, quer participando da administração pública — ou ambos-, foram sócios das companhias por ações surgidas em decorrência do Encilhamento. Toda a infraestrutura instalada àquela época estava baseada no desempenho dessas empresas, que formavam uma trama complexa e diversamente ramificada. Não é raro observar, quando se estuda o assunto hoje em dia, que determinada personalidade participava como acionista em várias empresas simultaneamente, assumindo diversos papeis, ora no corpo diretivo, como simples acionista.

Assim, formava-se uma rede de influências mútuas e múltiplas, na qual as informações eram compartilhadas entre todos. Era difícil perceber a quais interesses determinada sociedade dire- 
cionava-se. Essa rede complexa ramificava-se em dois âmbitos distintos: as esferas pública e privada e, não raro, tais limites não ficassem suficientemente claros (D’Elboux, 2015, p.242).

Como afirma D’Elboux (2015), a transição do Império para a República, no final do século XIX "reposicionou os papéis das instâncias municipais", criando o cargo do prefeito e seu papel administrativo. Neste contexto, a primeira vez que a palavra "melhoramentos" em São Paulo foi citada oficialmente trata da criação da Comissão Técnica de Melhoramentos em 1896, sob a chefia de Augusto Gomes Cardim. Comissão que então propunha a criação de um circuito perimetral "formado pela recém-inaugurada Avenida Paulista, pelas Avenidas Circular e Itatiaia, pelas ruas São João, Vergueiro e Liberdade, já existentes" (Campos, p. 74 apud D’Elboux, 2015, p. 261) que na altura da Avenida Itatiaia atravessava o já mencionado e distintivo Boulevard Burchard. Importante destacar que o termo "melhoramentos" surgiu antes mesmo de outros termos para designar a atividade de planejar obras urbanas e de organizar o crescimento da cidade (D’Elboux, 2015).

Na virada do século XX, a cidade de São Paulo foi então objeto de uma série de planos e leis - às vezes pontuais, outras de caráter mais abrangente, algumas contendo plantas, outras apenas textos - que propunham por diversas vias melhoramentos viários e embelezamento de áreas públicas. As disputas em torno destes planos envolviam a Prefeitura, o governo do Estado e por fim diversos atores privados que, como vimos acima, na passagem de D'Elboux, misturavam a chefia de variados negócios com propriedade de terras e cargos de diretoria em diversos órgãos e instituições. De diferentes maneiras, a maioria destes planos tratavam da abertura de grandes avenidas e do melhoramento da região central da cidade.

Alguns destes planos já se constituíam enquanto contratos entre o ente privado e o público envolvendo garantias, mobilização de terras e concessão de serviços nos moldes que vemos hoje nas concessões na cidade de São Paulo. Para ilustrar o tom de umas dessas propostas, Toledo resume as solicitações feitas pelo grupo 
do arquiteto Alexandre de Albuquerque ${ }^{4}$ em troca da abertura das avenidas da seguinte forma:

1. Direito de desapropriação dos prédios e terrenos numa faixa de largura de 80 metros de cada lado do eixo de cada avenida, com direito de revenda;

2. concessão para o estabelecimento de linhas de "ônibus-automóveis";

3. construção e prolongamento por conta do governo da rede de esgotos, canalização de água e de iluminação nas avenidas e praças logo que estivessem nivelados os respectivos leitos e antes da realização do calçamento, a fim de se evitarem subsequentes desmanchos e estragos;

4. garantia de juros de $5 \%$ por 10 anos sobre $40.000: 000 \$ 000$, correspondente à quarta parte do capital de 160.000:000\$000 orçado como necessário para a realização desse empreendimento (Toledo, 1983, p. 99).

A fervilhante discussão entre os diferentes planos foi arbitrada pelo arquiteto francês Joseph-Antoine Bouvard", que "ostentava o prestigioso título de Diretor Honorário dos Serviços de Arquitetura, Passeios, Vias-públicas e Plano da cidade de Paris" (Toledo, 1996, p. 91). O parecer sobre o conjunto de planos, elencando prioridades, foi formalizado por Bouvard em um relatório apresentado à Câmara pelo prefeito Barão de Duprat (1911-1914). Deste relatório, destacamos alguns trechos que nos parecem simbólicos para entender as formas como a cidade vinha se desenvolvendo e o caráter das proposições conciliadoras realizadas pelo arquiteto:

4. Plano chamado de "As grande avenidas" de autoria do arquiteto Alexandre de Albuquerque representando "os interesses de um grupo de empreendedores paulistas" (D'ELBOUX, 2015, p. 321)

5. 0 renomado arquiteto francês J. A. Bouvard já tinha feito planos urbanos para outras cidades do globo, tendo realizado propostas para Buenos Aires (Argentina) e Montevideo (Uruguai). 
(...) É necessário, de agora para o futuro, preencher os claros, o que será fácil se tomar a firme decisão de adoptar certo número de medidas tendo como consequência um efeito bem especial, tão interessante, como pittoresco.

É preciso, para esse fim, abandonar o systema archaico do xadrez absoluto, o princípio por demais uniforme da linha recta, vias secundárias que nascem sempre perpendicularmente da artéria principal.

(...) Em todas as disposições cumpre não esquecer a conservação e criação de espaços livres, de centros de vegetação, de reservatórios de ar. Mais a população aumentará, maior será a densidade da aglomeração, mais crescerá o número de construções, mais alto subirão os edifícios, maior se imporá a urgência de espaços livres, de praças públicas, de squares, de jardins, de parques, se impõe (Bouvard, 1911 apud Toledo, 1983, p. 102).

Importante destacar a associação que o arquiteto faz neste relatório entre crescimento populacional, adensamento, verticalização e a necessária abertura de espaços livres. De forma direta, temos aqui uma proposta de cidade que será importante para as discussões que se seguirão e que ditaram o desenho de algumas avenidas importantes da cidade, entre elas a São João ${ }^{6}$.

Anos depois, os diversos planos de melhoramentos que vinham sendo intensamente discutidos na esfera pública adquirem uma feição mais abrangente nos artigos publicados no boletim do Instituto de Engenharia entre 1924 e 1926 por

\footnotetext{
6. Ainda sobre o arquiteto Bouvard, devemos destacar não só a atuação dele na esfera pública dos planos, mas também como consultor privado de empresas internacionais na procura de negócios imobiliários em terras Paulistas. Essa dupla atuação é descrita por D'Elboux da seguinte forma: "A ação de Bouvard em São Paulo dá-se em dois âmbitos. De um lado, na esfera pública, atua na resolução da questão da ocupação da área do vale do Anhangabaú, propondo solução conciliadora que contempla os diversos interesses em jogo. [...]. De outro lado, na esfera privada, presta assessoria a [o banqueiro Belga] Laveleye, através da escolha de terras e negociação com proprietários, resultando na aquisição de mais de $12.000 .000 \mathrm{~m}^{2}$ de terrenos, o que totalizava um terço da área urbanizada da cidade à época. Através da proposta de Bouvard o centro da cidade transforma-se profundamente" (D'Elboux, 2015, p. 232).
} 
Francisco Prestes Maia e João Florence de Ulhôa Cintra intitulados "Um problema atual: os grandes melhoramentos de São Paulo" (Toledo, 1996, p. 119). Boletins que culminaram, em 1930, na publicação da primeira versão do "Plano de Avenidas para a Cidade de São Paulo", a pedido do então prefeito José Pires do Rio ao Prestes Maia enquanto João Florence de Ulhôa Cintra era presidente da Comissão de obras do Tietê. Em resumo, Toledo descreve o plano:

\footnotetext{
O Plano de Avenidas sugere, como complemento da lei de arruamentos, o estabelecimento de um sistema radial-perimetral, devidamente adaptado à topografia e constituído por uma malha de vias diferenciadas, como modo de expansão da cidade. As vias principais que formam a malha fundamental são largas e direitas, com caráter comercial. As vias secundárias complementam a malha, sendo, geralmente, residenciais e destinadas ao tráfego local. (Toledo, 1996, p. 220).
}

O plano se apresentava como um conjunto de vias radioconcêntricas que partiam da colina história, arituladas por uma série de anéis sucessívos construídos para distribuir os fluxos. Destas vias radiais, a São João, já com 30 metros de largura, constituiu parte do substrato material para o plano. Importante para este trabalho o vínculo que o plano urbano estabelecia com a arquitetura a partir do arruamento. Na imagem ao lado (fig. 1.1.1), retirada do Plano, vemos a seção transversal de uma via arterial e verificamos a relação destas avenidas com o passeio público e os altos edifícios aos lados, conforme proposto também no relatório de Bouvard. Em ambos planos podemos observar como eles não só sugerem a intensificação da produção imobiliária mas no caso deste último determinavam alturas mínimas associada à abertura de avenidas que variavam entre os 22 e 39 metros (Campos, 2008, p.38).

Nesse sentido em 1928 foi regulamentada (Decreto n.

$5.481 / 1928)$ a forma condomínio para edifícios de mais de cinco andares, viabilizando a propriedade compartilhada do solo e dando segurança para a atividade imobiliária. A importância do instituto da forma condomínio é apontada por Rufino da 


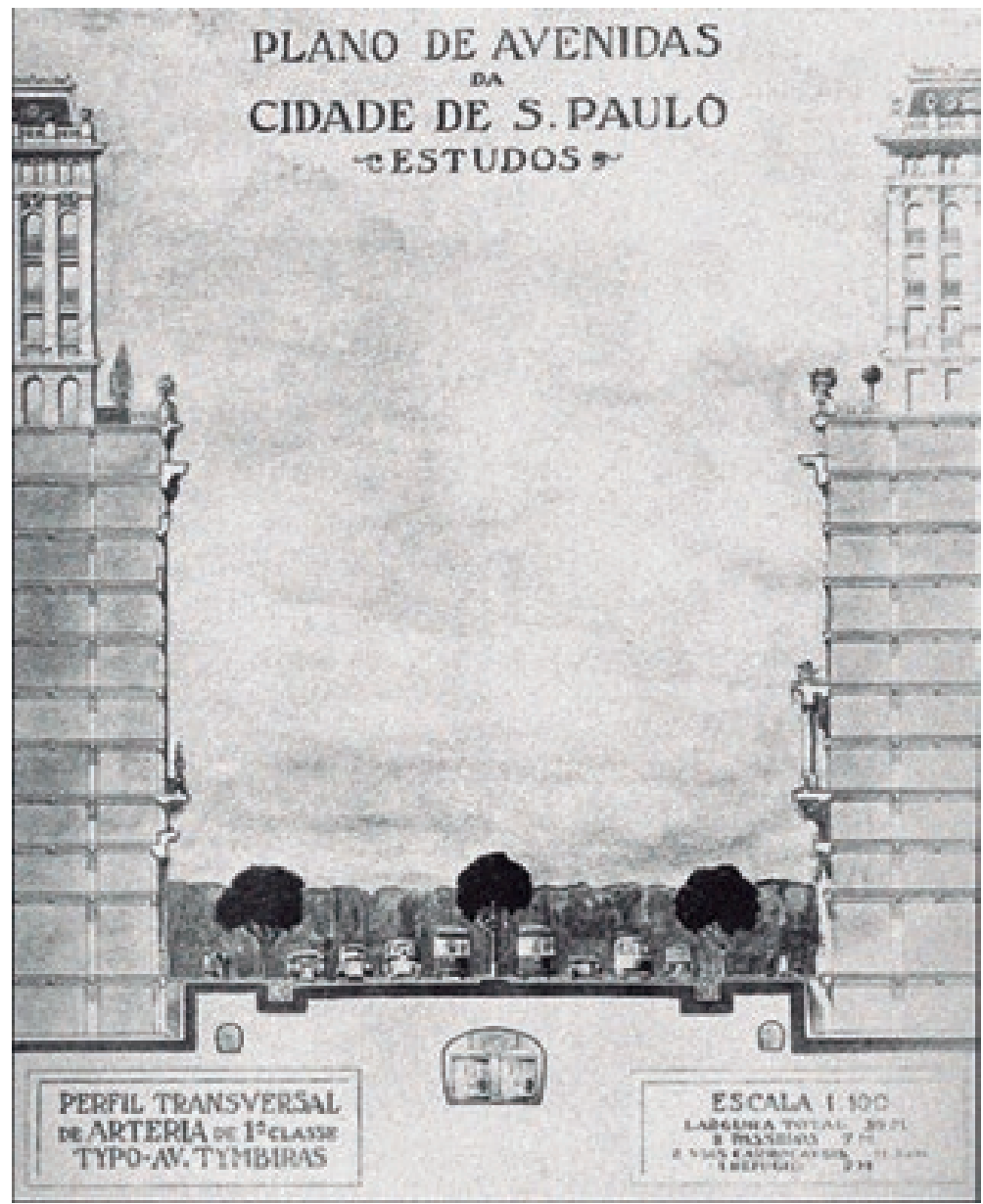

Fig. 1.1.1

Plano de Avenidas da Cidade de São Paulo. Toledo, 1996.

seguinte forma: "a fragmentação da propriedade da terra e a multiplicação dos proprietários é alcançada a partir da instituição de uma nova forma de propriedade, o condomínio, que torna-se central no avanço das relações capitalistas de produção do espaço" (Rufino, 2012, p. 208).

A inauguração de novos serviços públicos de luz e transporte, os vários melhoramentos das áreas públicas da cidade mudariam de forma significante a feição da cidade que também "passou a contar com bons hotéis, restaurantes, confeitarias, novos teatros e um comércio capaz de atender aos consumidores mais exigentes" (Toledo, 1996, p. 41). Estabelecimentos comerciais e de serviços que paulatinamente foram se implantando próximos da 
Avenida São João a partir do Vale do Anhangabaú 7 . Daqui surge o apelido Cinelândia paulistana conforme descreve Campos: “a região entre Paissandu, São João e Ipiranga ganhava cinemas luxuosos e passava a concentrar a vida noturna de bares e restaurantes do melhor padrão, logo ganhando o apelido de Cinelândia paulistana" (Campos, 2008, p. 38).

A forma como São Paulo se desenvolveu, combinando de um lado o loteamento desarticulado de chácaras e do outro o adensamento em altura, constituiu diferentes escalas de produção imobiliária e contribuíram para o crescimento desigual da metrópole. Dada a heterogeneidade deste desenvolvimento, a propriedade seria precificada também de forma diferencial, combinando estratégias de valorização e de capitalização. Sobre estas escalas, extensiva e intensiva, e as estratégias de precificação Pereira (1988) afirma:

(...) extensiva, em relação à apropriação do território para ocupação urbana; intensiva, quando a ocupação dava-se de modo adensado em relação a esse processo de apropriação. A disritmia dessas escalas de produção configurava desigualdades no crescimento da cidade, tanto pelo adensamento do espaço urbano já existente, como pela criação de um espaço novo adicional. (Pereira, 1988, p. 90).

De um lado, onde os preços finais de mercado eram elevados, construía em altura e subdividia edifício em unidades menores para serem alugados a várias famílias. De outro, agia extensivamente, com a construção deslocando-se para áreas menos centrais da cidade, onde o preço dos terrenos não havia se elevado muito e podia proporcionar lucro extraordinário ao construtor. (Pereira, 1988, p. 93).

Uma das grandes empresas que ilustram essa forma dual pela qual o desenvolvimento imobiliário se deu foi o Banco Nacional 
Imobiliário (BNI), fundado por Octavio Frias e Orozimbo Roxo Loureiro, cujo quadro de colaboradores contou com a participação do próprio Prestes $\mathrm{Maia}^{8}$. A empresa combinava ambas escalas de produção: por uma lado a produção de grandes empreendimentos, com mais de 1500 quitinetes produzidas a partir do ano de sua fundação em 1946 (Lores, 2017, p. 63), por outro o lançamento de bairros afastados do Centro como o Jardim do Morumbi, para o qual se mudaria a sede do governo do Estado anos depois.

Além de intensificar o aproveitamento do solo, a pulverização da propriedade em unidades menores e a produção de grandes empreendimentos permitiu aumentar o número de mutuários necessários para constituir o funding para o início das obras do empreendimento, em um momento prévio à constituição dos grandes programas de financiamento federais ( $\mathrm{SFH}$ e $\mathrm{BNH}$ ). O formato do negócio imobiliário chamado de "obra a preço de custo" foi a forma como edifícios residenciais passaram a ser financiados pelos próprios compradores das unidades. Por meio de uma primeira entrada e parcelas regulares, as quitinetes permitiam ao mesmo tempo aumentar o número de financiadores e diminuir o valor da parcela. Neste rol de empreendimentos, devemos destacar o papel dos arquitetos expoentes da arquitetura moderna e a pesquisa em torno do desenhos de unidades habitacionais mínimas, "máquinas de morar", dentre eles o arquiteto carioca internacionalmente reconhecido Oscar Niemeyer.

O anúncio da próxima página (fig. 1.1.2) ilustra como as transformações impactaram no entorno da Avenida São João. Nesta imagem, datada do dia 21 de julho de 1957, vemos um casarão localizado na divisa entre o atual bairro de Higienópolis e a Barra Funda à venda. Anunciado como grande oportunidade para a realização de um empreendimento de "lojas e apartamentos" o anúncio ilustra a potência desta transformação: o

8. Prestes Maia foi responsável pelo projeto do Edifício Coliseu Capitólio Palatino, inaugurado em 1951 no Largo do Arouche.

9. Batizadas assim por Le Corbusier em 1921 na publicação Esprit Nouveau (Le Corbusier, 2004, p. 94). 
Fig. 1.1.2

Anúncio de terreno à venda. Folha da Manhã, 1957.

Fig. 1.1.3

Fotografia da Av. General Olímpio da Silveira. $\mathrm{S} / \mathrm{n}, \mathrm{s} / \mathrm{d}$.
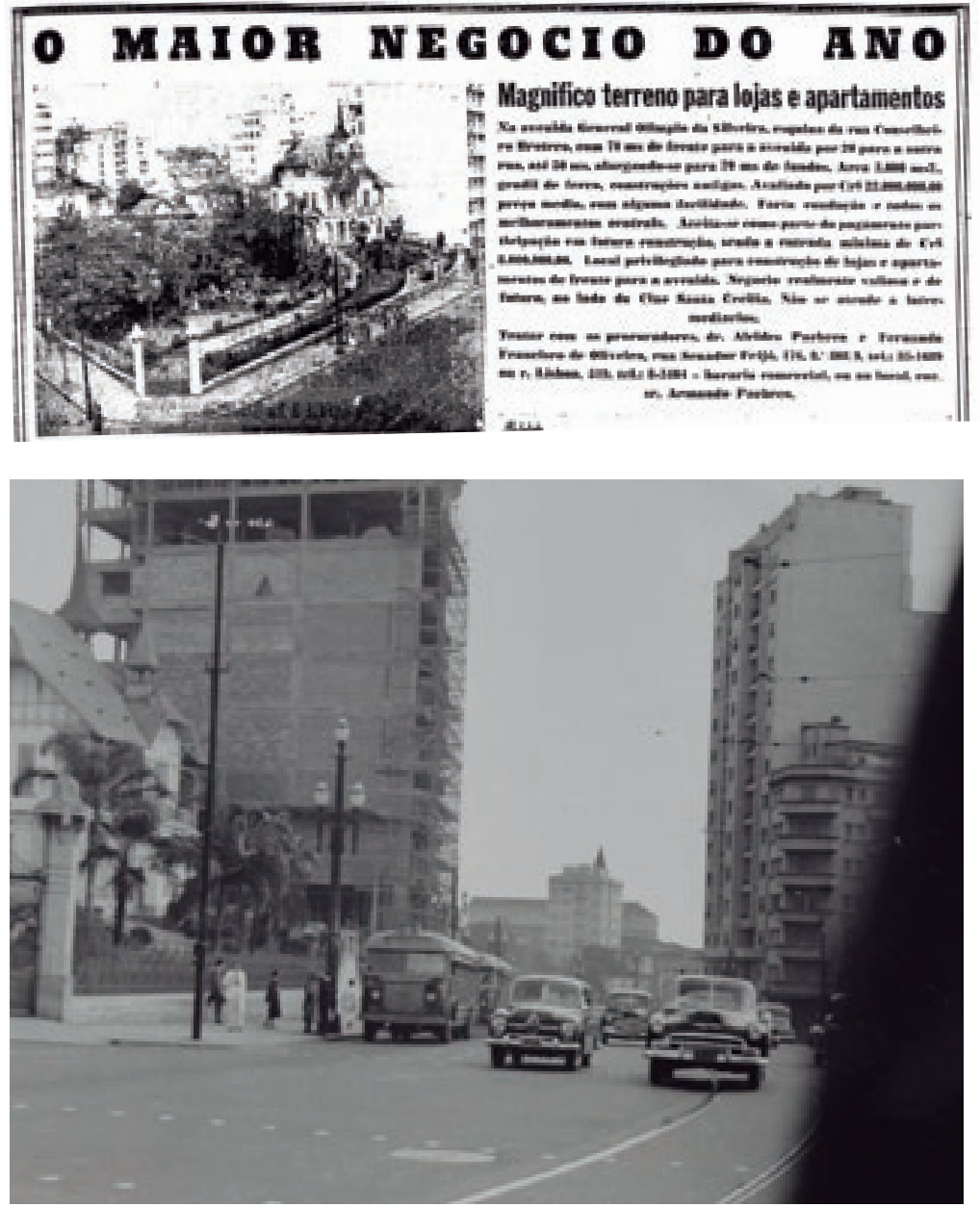

eixo tinha se transformado em uma referência comercial e cultural da cidade onde se avolumavam edifícios comerciais e habitacionais. Na imagem seguinte (fig. 1.1.3), vemos um edifício alto sendo construído logo ao lado deste terreno e outros edifícios na calçada da frente e ao fundo. No anúncio, também podemos observar o destaque dado à situação do terreno em relação ao cinema "local realmente valioso e de futuro, ao lado do Cine Santa Cecília”.

Ao longo das primeiras décadas do século XX, o alargamento da Av. São João foi acompanhado de uma série de praças (do Correio, Largo do Paissandu, da Vitória e a Marechal Deodoro (fig. 1.1.4)) até a sua finalização no largo das Per- 


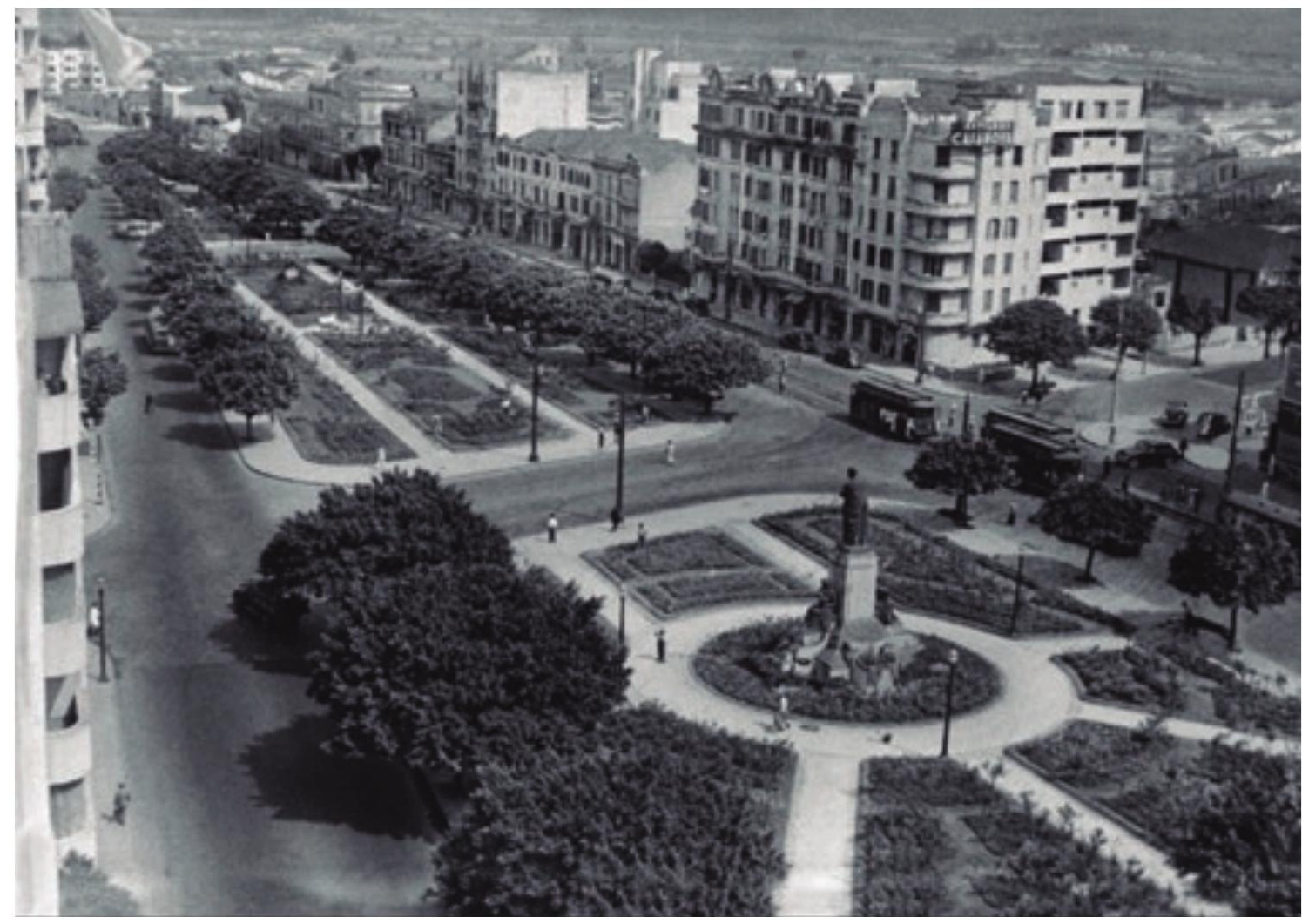

Fig. 1.1.4

Fotografia da Praça

Marechal Deodoro.

Duarte, s/d.

dizes por Prestes Maia. Desde a sua fundação, passando pela construção do Ed. Martinelli em $1929^{10}$, o traçado longo e retilíneo da Av. São João conhecera intensa atividade imobiliária; aqui instalaram-se hotéis e edifícios de quitinetes, reforçando o viés intensivo pelo qual a propriedade passou a ser explorada.

Encerramos esta primeira recuperação histórica com duas imagens da Av. São João para ilustrar a feição da avenida antes das grandes obras viárias da gestão Faria Lima (1965-

10. Primeiro arranha-céu da cidade localizado na praça Antônio Prado, em uma das extremidades deste eixo. 


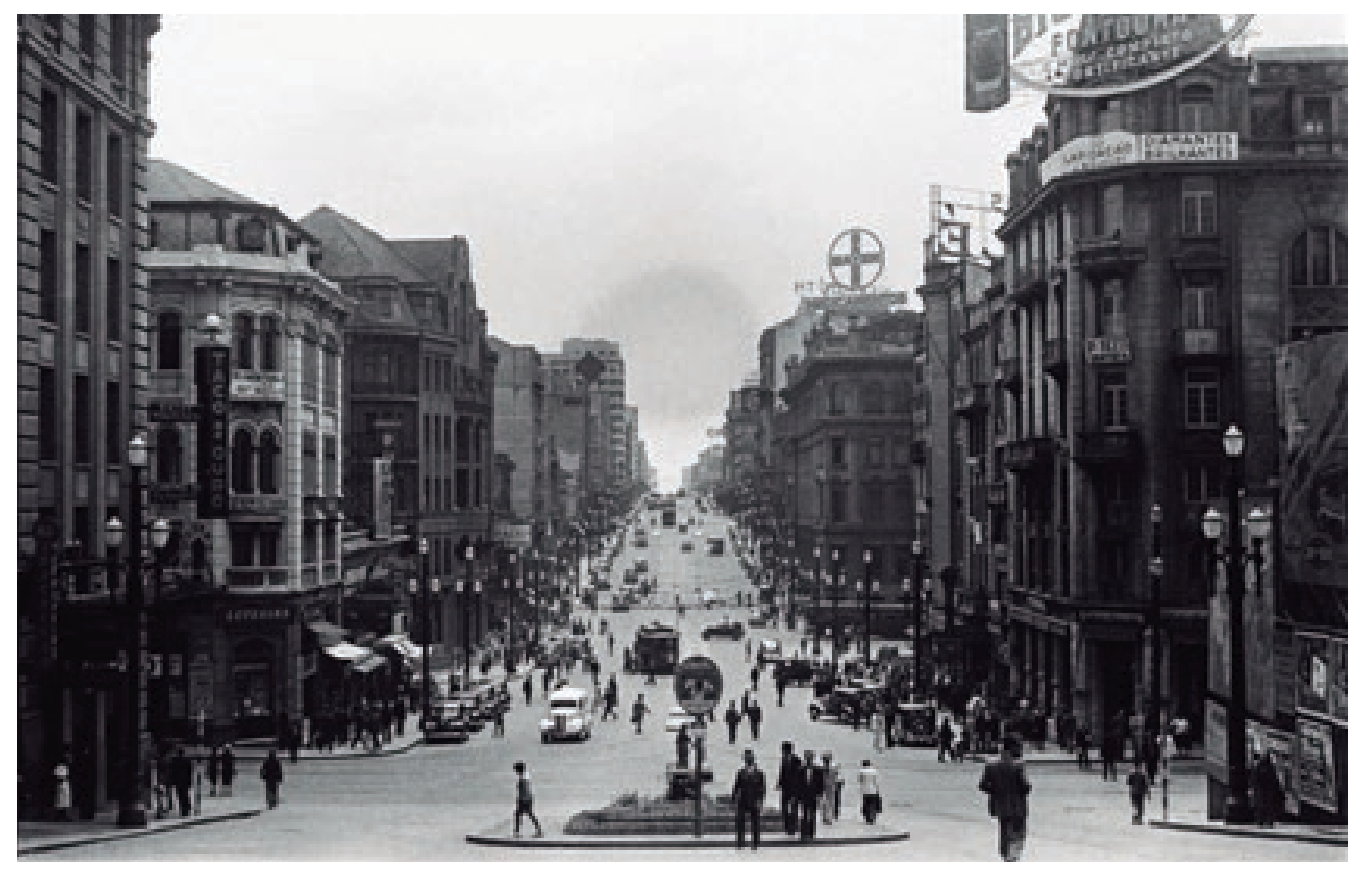

Fig. 1.1.5

Fotografia da Av. São João. Duarte, s/d.
1969) e da posterior construção do Elevado Costa e Silva (1971). Na primeira imagem (fig. 1.1.5) observamos da altura do pedestre o perfil desta da via, constituída por um ritmo contínuo de edifícios relativamente altos com térreos ocupados por comércios diversos e anunciando mercadorias da época nas coberturas. Na figura seguinte (fig. 1.1.6), vemos a mesma avenida fotografada do alto, próximo à praça Marechal Deodoro sentido Centro, evidenciando a força que constituiu esse eixo na expansão da cidade para fora do centro histórico. 


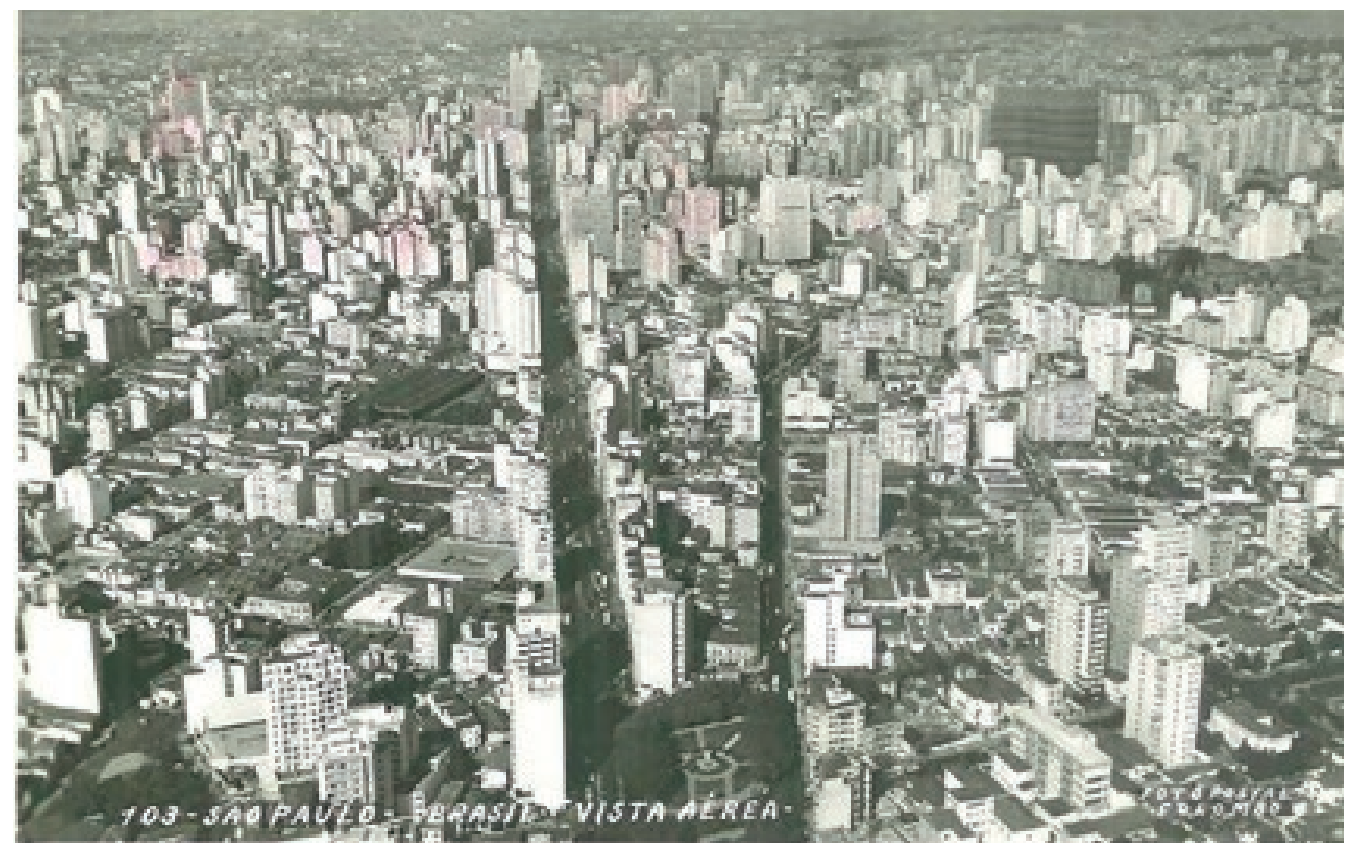

Fig. 1.1.6

Fotografia aérea da Av.

São João.S/n, s/d. 


\title{
A construção do Elevado Costa e Silva: a cidade para o automóvel e a "generalização" da produção imobiliária intensificada
}

Se por um lado, os planos de melhoramentos do começo do século estavam preocupados com a qualificação da malha viária e com a provisão de "belos" espaços livres, por outro fundaram uma forma de projetar a cidade pautada na valorização das avenidas e com elas do automóvel. Décadas depois, este meio de deslocamento sustentaria um modo de construir cidades muito diferente dos planos do começo do século XX, talvez antagônico. $\mathrm{O}$ modelo de cidade rodoviarista marcou uma nova forma de projetar o desenvolvimento da cidade ao longo das décadas seguintes e encontra seu fundamento, de acordo com Nobre nas seguintes hipóteses:

\begin{abstract}
A partir das décadas de 1940 e 1950, o urbanismo rodoviarista vai ganhar forte impulso a partir de dois fatores (Lagonegro, 2003): em primeiro lugar, a política de aproximação com o governo dos EUA, iniciada com o advento da II Guerra Mundial e intensificada pela Guerra Fria; em segundo lugar a instalação da indústria automotiva na Região Metropolitana de São Paulo. (Nobre, 2010, p. 3)
\end{abstract}

Em 1949, Robert Moses ${ }^{11}$ foi chamado pela prefeitura de São Paulo para elaborar um programa de melhoramentos que resultaria na continuidade do Plano de Avenidas do Prestes Maia.

11. Robert Moses "foi coordenador do Departamento de Obras, presidente da Comissão de Remoção de Cortiços e do Conselho de Parques de Nova Iorque. Moses dominou o cenário político nova iorquino de 1924 a 1968, sendo responsável pela reestruturação de sua região metropolitana, através de um extenso programa de construção de vias expressas, parques e equipamentos públicos" (Nobre, 2010, p. 3). 
O arquiteto tinha sido responsável pela promoção de parques, parkways e grandes obras viárias de macroacessibilidade na região metropolitana da cidade americana, iminente signo de modernidade e prosperidade na nova configuração geopolítica do pós-guerra. A contratação do arquiteto americano, conforme aponta Nobre, seria viabilizado por Nelson Rockfeller através da IBEC - International Basic Economy Corporation, empresa fundada pelo empresário com o intuito de "fomentar a criação de negócios competitivos em países em desenvolvimento" (Nobre, 2010, p. 4) e que viria a reforçar os vínculos do país com a crescente potência americana. Interessante aqui destacar o cargo que $\mathrm{o}$ arquiteto ocupara em Nova Iorque, que vinculava, ao menos no nome, obras à remoção de cortiços e à gestão de parques: Coordenador do Departamento de Obras, Presidente da Comissão de Remoção de Cortiços e do Conselho de Parques.

Dentro das propostas de Moses para Manhattan, cabe destacar aquela de 1959 chamada Lower Manhattan Expressway (fig. 1.2.1), que ilustra uma mudança importante de paradigma urbano com relação às parkways inauguradas pelo mesmo arquiteto, na mesma cidade, décadas antes. Nesta proposta, sugere-se interligar os túneis sob o Rio Hudson, a oeste da ilha, às pontes Williamsburg e Manhattan; a leste, por meio de uma via expressa elevada, cortando ao meio o centro da cidade. A proposta, emblemática para o que viria ser em São Paulo uma década depois o Elevado Costa e Silva, ficou famosa pelo intensa debate público encabeçado pela escritora Jane Jacobs que resultou no cancelamento do projeto. Em 1961, ela escreveu o livro "Morte e Vida de Grandes Cidades", no qual a escritora discute, justamente, como as grandes cidades "morriam" em projetos de grande envergadura como este.

Em 1950, Moses entregou um relatório que buscava adequar o Plano de Avenidas à nova realidade metropolitana (Nobre, 2010, p. 5). O plano propunha uma série de novas avenidas nos fundos de vale de rios até então deixados à margem da urbanização, incluindo um anel de vias expressas nas margens dos Rios Tietê 


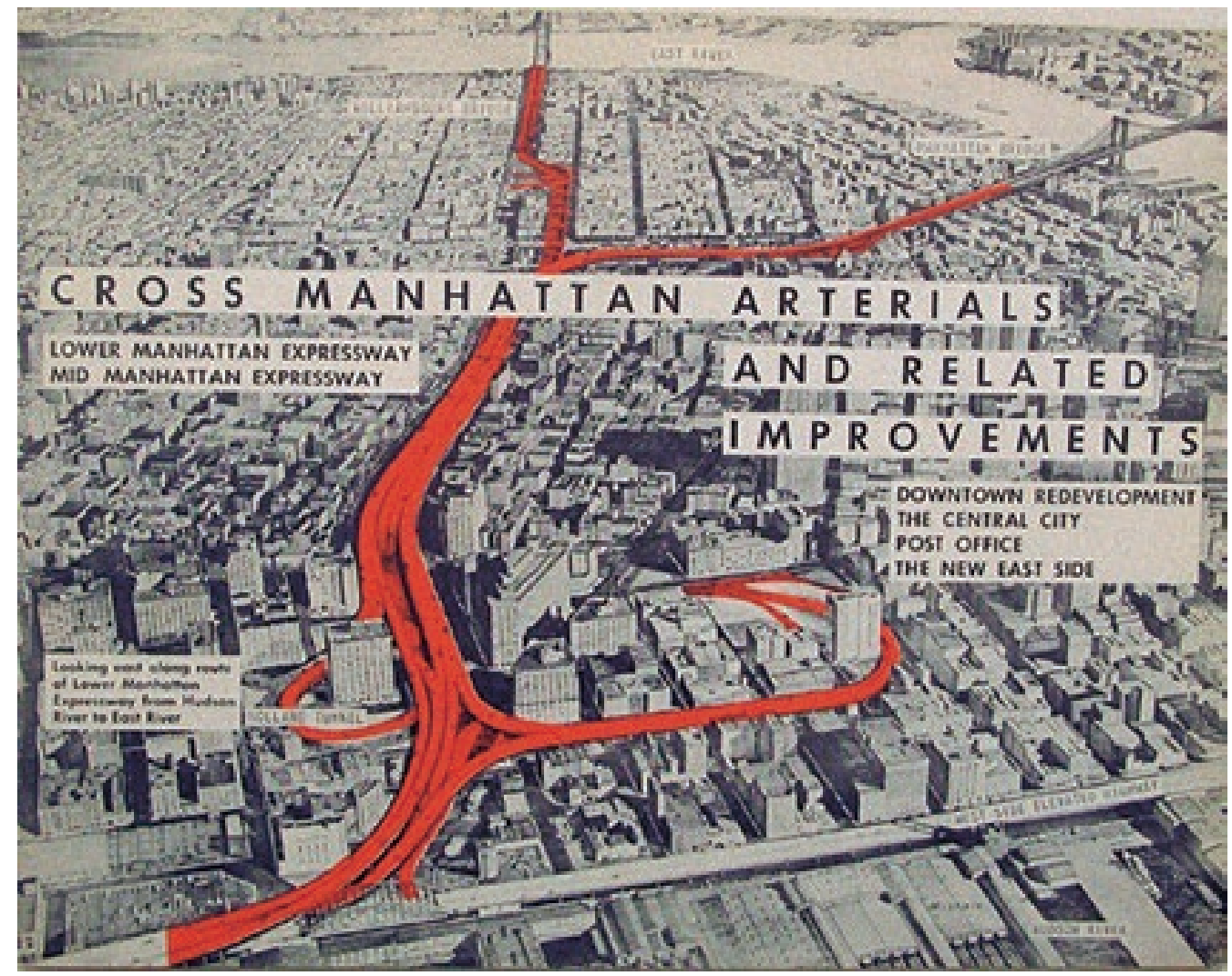

Fig. 1.2.1

Ilustração da proposta Lower Manhattan Expressway. Moses, 1959. e Pinheiros ${ }^{12}$, interligado às estradas recém-inauguradas: Anchieta, Anhanguera e Dutra. Ainda que seu antecessor já tivesse realizado avenidas em fundos de vale, a grande diferença deste plano com relação às avenidas propostas por Prestes Maia, conforme apontam os autores Anelli e Seixas (2008), seria a introdução da "via expressa com o tráfego separado das interferências da malha urbana" (Anelli, Seixas, 2008, p. 65):

Enquanto a Avenida 9 de julho, aberta em 1939, segue pelo vale do Saracura ao longo de prédios e cruzamentos em níveis, a Avenida 23 de Maio, construída em 1960, segue isolada em trincheira, com os acessos e saídas controlados por faixas de aceleração e desaceleração. De fato, há nestes intervalo de

12. A proposta de construção de avenidas juntos aos Rios Tietê e Pinheiros não se trata de uma proposta inovadora de Moses, tendo já sido proposta no Plano de Avenidas de Prestes Maia no formado de avenidas parques. 
vinte anos uma significativa alteração nos padrões do projeto viário. Enquanto a Avenida 9 de Julho pode ser alinhada entre as tributárias das parkways norte-americanas, a Avenida 23 de Maio é - assim como o Elevado Costa e Silva - expressão de uma visão que se firmou dentro da engenharia de transportes, particularmente norte-americana. (Anelli, Seixas, 2008, p. 66).

Conforme apontam Anelli e Seixas, "o Elevado já podia ser considerado uma tipologia consagrada" buscando resolver "o conflito entre trajetórias diferentes de veículos e pedestres tendo em vista o vertiginoso aumento nos volumes de tráfego urbano" (Anelli, Seixas, 2008, p. 61). Além do antecedente do S-Bhan ${ }^{13}$ do final do século XIX, os autores apontam o pavilion "Futurama: Highways and Horizons" da GM (General Motors), na Exposição Internacional de Nova Iorque de 1939 (dirigida por Roberto Moses), como uma das mais importantes propagandas desta nova cultura urbana. O pavilhão (fig. 1.2.2) projetado por Norman Bel Geddes apresentava a cidade do futuro 20 anos a frente (1959): flutuando sobre grandes maquetes, os visitantes eram guiados sobre a cidade do futuro que por meio de largas vias expressas e obras de engenharia articularia a vida moderna nas grandes metrópoles com a vida bucólica dos subúrbios, conectando a dicotômica relação campo/cidade. Os novos horizontes desenhados pela GM combinavam a liberdade de deslocamentos dada pelo automóvel com os anseios de um futuro conectado, seja pelas vias expressas, seja pela domesticação dos aparelhos de comunicação e transportes que ganhavam, gradativamente, espaços no interior das residências.

O modelo de cidade rodoviarista ganharia fôlego no governo Juscelino Kubitschek (1956-1961) pela regulamentação e incentivo à indústria de automóveis, incluindo a criação do GEIA (Grupo Executivo da Indústria Automobilística). A partir deste momento as indústrias, que além de montar os veículos passaram a produzir as peças, instalaram-se na região do $\mathrm{ABC}$ Paulista, perto da Via Anchieta, entre o porto de Santos e o centro da 
cidade. Em 1961, a rede de bondes instalada em São Paulo pela companhia canadense The São Paulo Tramway Light and Power Co. Ltda., que contava com mais de $300 \mathrm{~km}$ de trilhos, passaria a ser desativada, consolidando a supremacia das rodas sobre os trilhos, como acontecera em outras cidades do globo.

A contínua construção de avenidas e vias expressas ao longo do final da década de 1950 e da década seguinte, como a 23 de Maio, a Marginal Tietê e a Pinheiros, sustentaram o contínuo espraiamento da cidade que, em 1970, praticamente tinha englobado a maioria dos municípios vizinhos. Os problemas de trânsito se intensificavam à medida que a cidade se expandia órfã de um transporte coletivo de massa veloz, sustentando o grande volume de deslocamentos sobre a precária rede de transportes coletivo sobre rodas.

O golpe militar de 1964 determinou o início de um processo de centralização política-institucional e regulação econômica. O Banco Nacional de Habitação (BNH) foi instituído neste ano pela mesma Lei (Lei n. 4.380) que criou o Sistema Financeiro de Habitação (SFH) e fundaram as bases da principal via de financiamento imobiliário até os dias de hoje. O aparato institucional proposto pelo Governo Federal no SFH se baseou no modelo americano de savings and loans: captação de recursos via poupança compulsória (FGTS) e não compulsória (SBPE) para injetar grande volume de capitais no financiamento da produção imobiliária. Foi, portanto, apenas pela constituição do Fundo de Garantia por Tempo de Serviço (FGTS) - pela Lei n. 5.107 em 1966 - e pela regulamentação da caderneta de poupança, em 1968, que se criaram as condições necessárias para a estruturação do primeiro fundo público, de porte relevante, para o setor habitacional.

O trabalho de Royer (2006) mostra que, apesar de polêmico do ponto de vista da produção habitacional para atendimento das camadas de ingressos mais baixos (de 0 a 3 salários-mínimos), a produção de unidades habitacionais como um todo teve um aumento expressivo no período de vigência do $\mathrm{BNH}$, principalmente se comparada ao período que sucedeu a sua extinção.
Fig. 1.2.2

Fotografia interna do pavilhão Futurama:

Highways and Horizons. Geddes, 2013. 


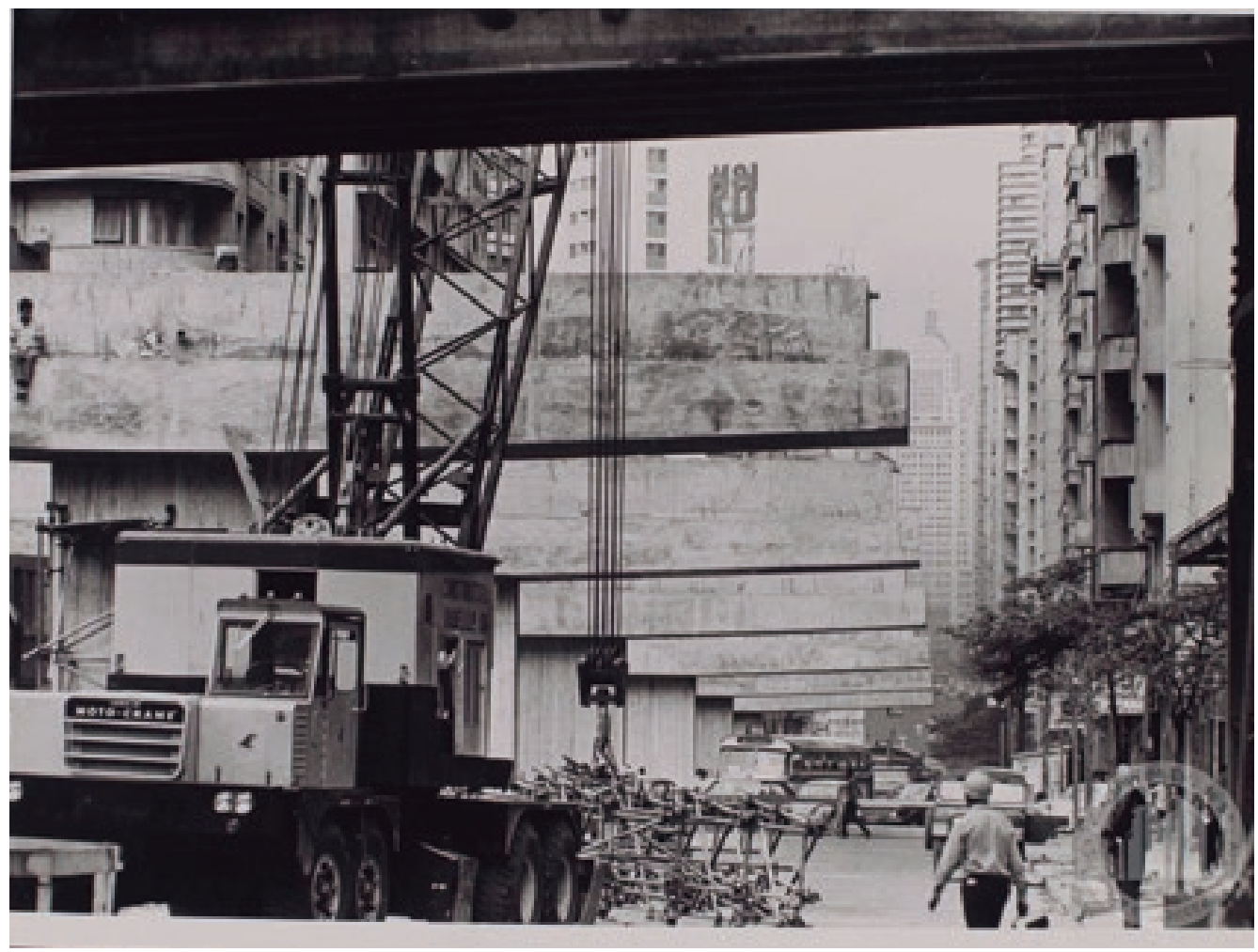

Fig. 1.2.3

Fotografia da construção do Elevado Costa e Silva. Arquivo 0 Estado de SP, 1970.
$\mathrm{O}$ volume de financiamentos concedidos via SFH passou de aproximadamente 550.000 unidades em 1980 para 60.000 em 1993.

Após a promulgação do Ato Institucional n.5, em 1968, os prefeitos passaram a ser então nomeados por eleições indiretas mediante indicação da cúpula militar (Arretche, 1997, p. 20). Paulo Maluf seria então o primeiro prefeito biônico a assumir o cargo em 1969 dessa forma, que ficaria vigente até 1986 quando Jânio Quadros assumiu como primeiro prefeito eleito no período de redemocratização do País. Esta estrutura autoritária e altamente hirarquizada do governo militar limitou a "grande parte da atividade de planejamento no plano local" ao restringí-la a "formular projetos de solicitação de recursos para o Governo Federal, nos termos previstos pela agência federal encarregada da implementação de uma dada política" (Arretche, 1997, p. 20). 


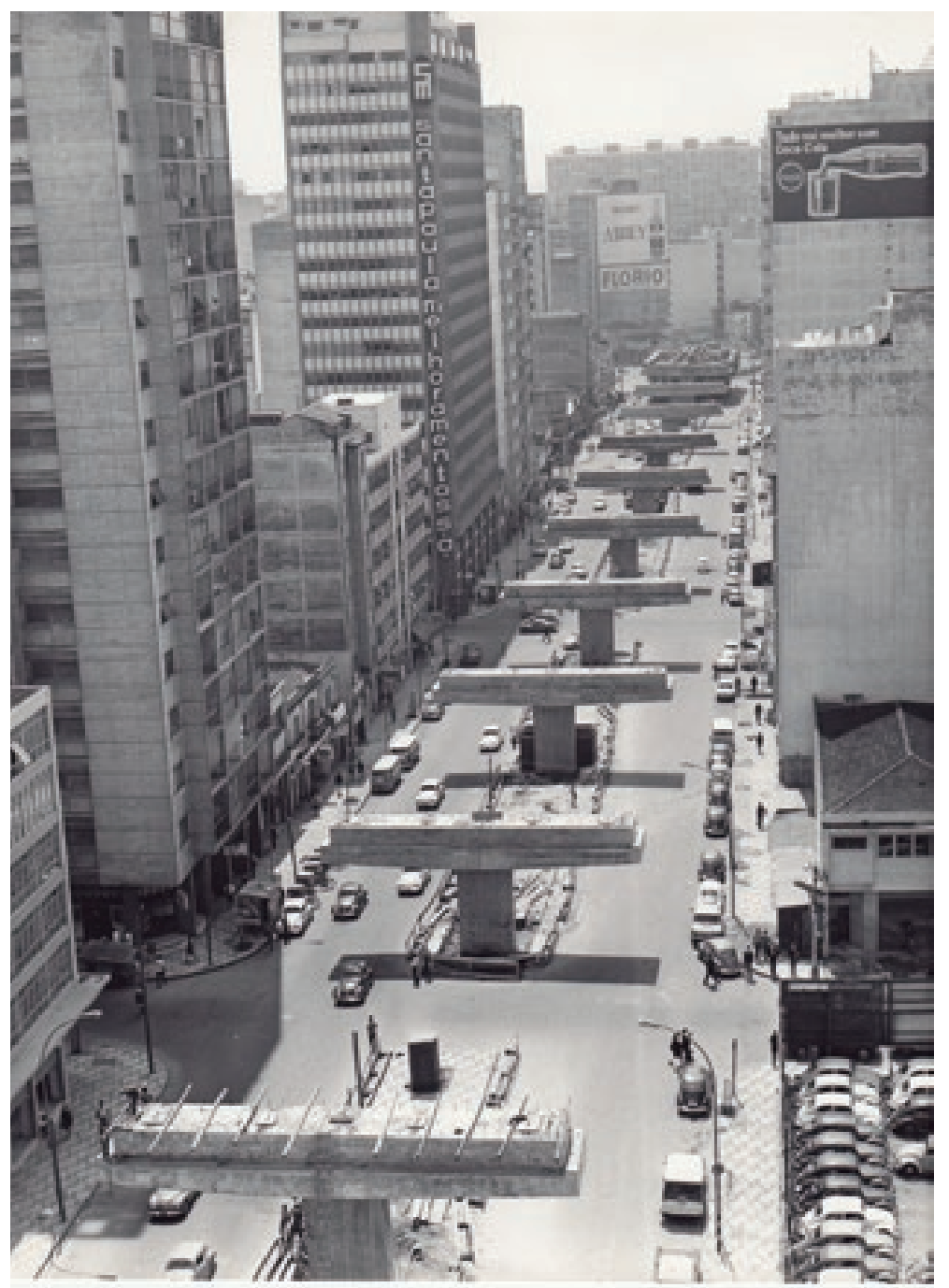

Fig. 1.2.4

Fotografia da construção do Elevado Costa e Silva. S/n, 1970.

Foi neste contexto, em 1969, que Paulo Maluf contratou a Hidroservice Engenharia de Projetos para projetar o Elevado Costa e Silva. A via expressa exclusiva para o transporte de veículos motorizados, então batizada de Elevado Costa e Silva, foi concebida como parte integrante de um complexo viário para interligar de forma expressa a Zona Leste de São Paulo à Zona Oeste, cruzando o centro da cidade. Caracterizada como uma via elevada de mão dupla, construída em concreto armado protendido, ela recebeu o apelido de Minhocão pela sua longa extensão (2,8 km) e seu desdobramento sinuoso sobre a malha urbana, serpente- 


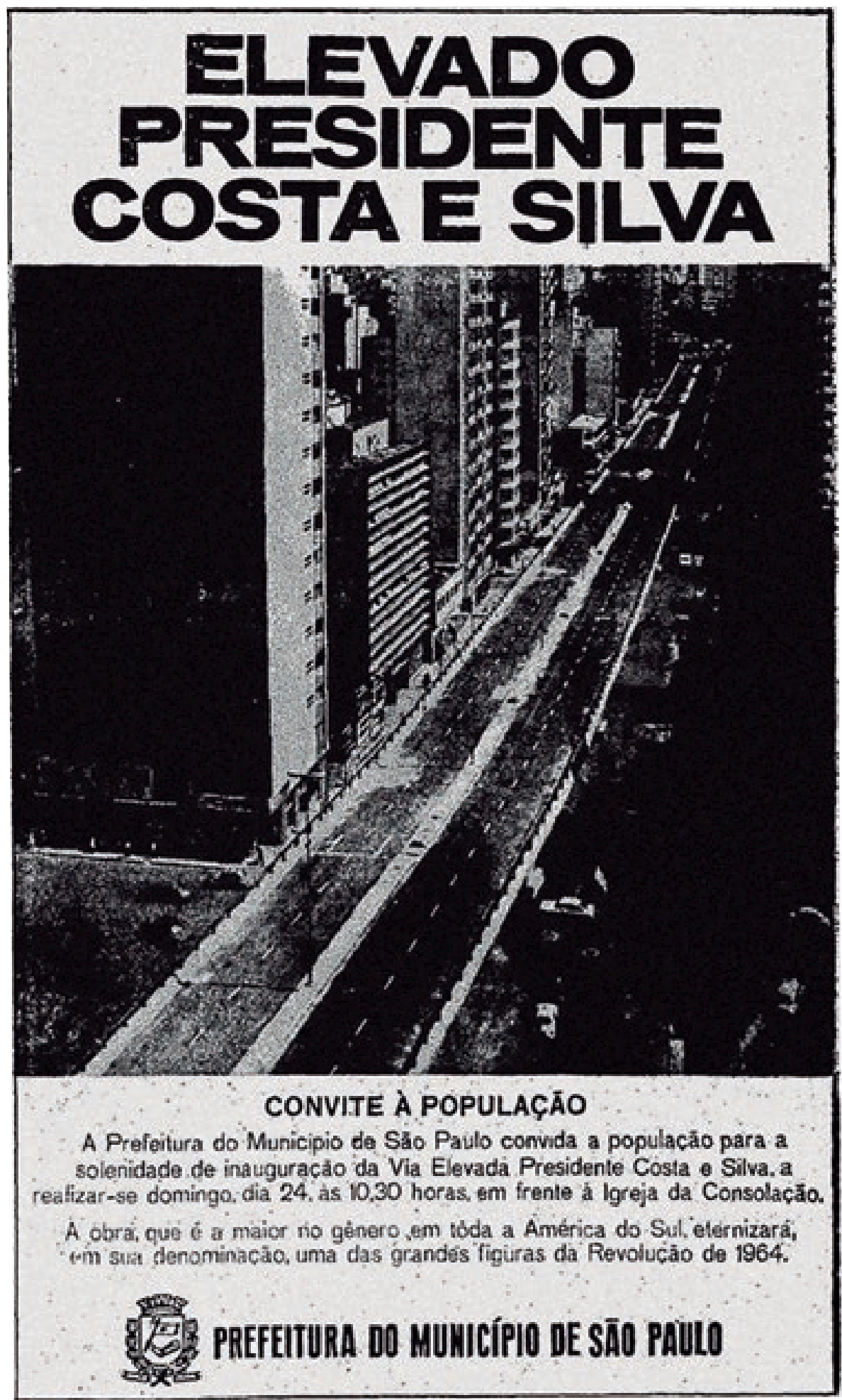




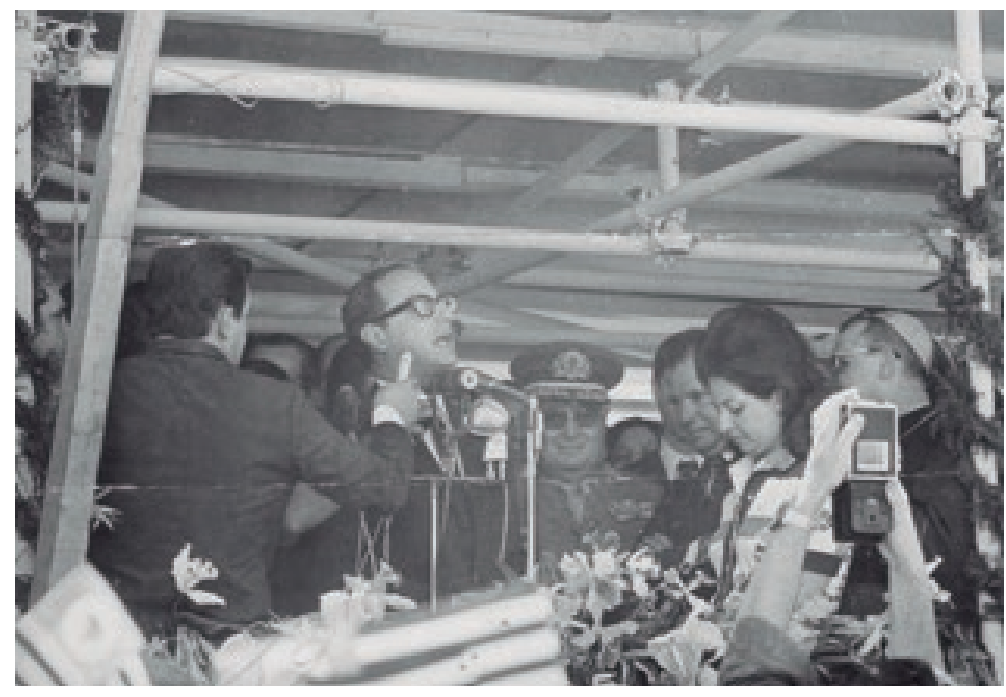

ando sobre as Avenidas Francisco Matarazzo, General Olímpio da Silveira, São João e a rua Amaral Gurgel para interligar o Largo Padre Péricles, em Perdizes, à Praça Roosevelt, no Centro. Construído em pouco mais de um ano (fig. 1.2.3 e 1.2.4) ela foi inaugurada no dia 25 de janeiro de 1971 (fig. 1.2.5) — data de aniversário da cidade de São Paulo.

As obras de engenharias em concreto armado, que já desfilavam pelo mundo principalmente após a construção de Brasília e das obras monumentais de Niemeyer, agora financiadas pelo então governo militar carregam consigo os valores do "milagre econômico" e do sucesso da engenharia nacional. Conforme aponta o anúncio de inauguração do Elevado, publicado no jornal Folha de S. Paulo no dia 24 de janeiro de 1971 (fig. 1.2.6), tratava-se da maior obra em concreto armado da América Latina e seu nome "eternizava" o recém-falecido presidente do governo militar Artur da Costa e Silva ("umas das grandes figuras da Revolução de 1964").

Nos jornais da época podemos observar anúncios de empresas que trabalharam na construção do Elevado; a própria Hidroservice em página dupla anunciava uma das obras "mais importantes do gênero em todo o mundo" (fig. 1.2.7). Podemos também ver a empresa Mangels que com orgulho publicava em
Fig. 1.2.6

Fotografia do Pref. Paulo Maluf na inauguração do Elevado. Folhapress, 1971.
Fig. 1.2.5

Convite para inauguração do Elevado Costa e Silva. Folha de S. Paulo, 1971. 
Fig. 1.2.7

Anúncio publicitário da

empresa Hidroservice.

Folha de S. Paulo, 1971.

\subsection{METROS DE IDÉIAS

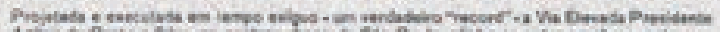

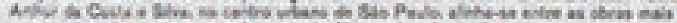

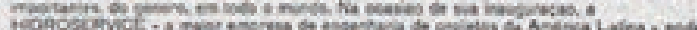

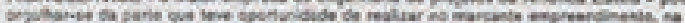

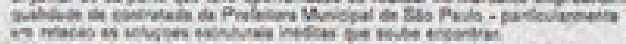

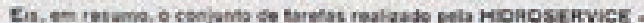 Engenkaria se Prolesos Lada:

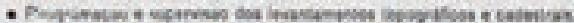

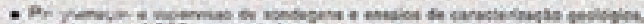

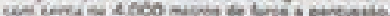

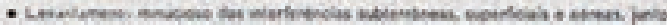

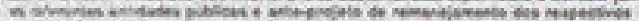

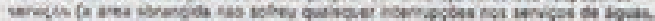

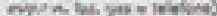

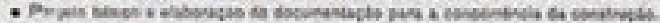

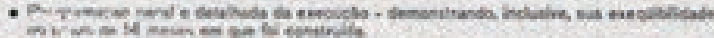

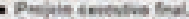

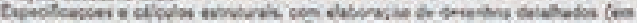

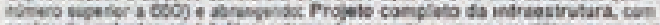

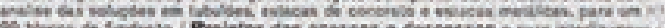

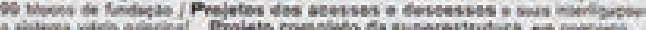

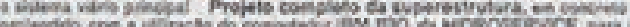

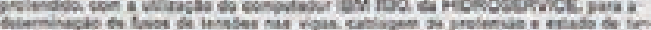

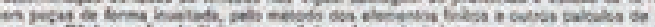

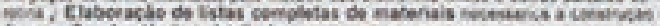

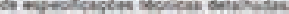

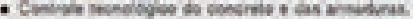

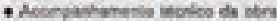

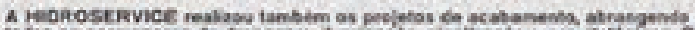

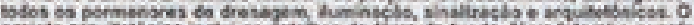

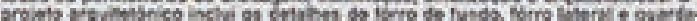

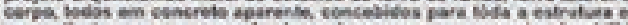

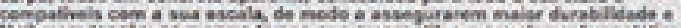

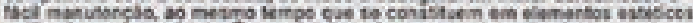

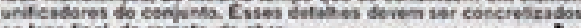

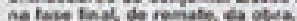

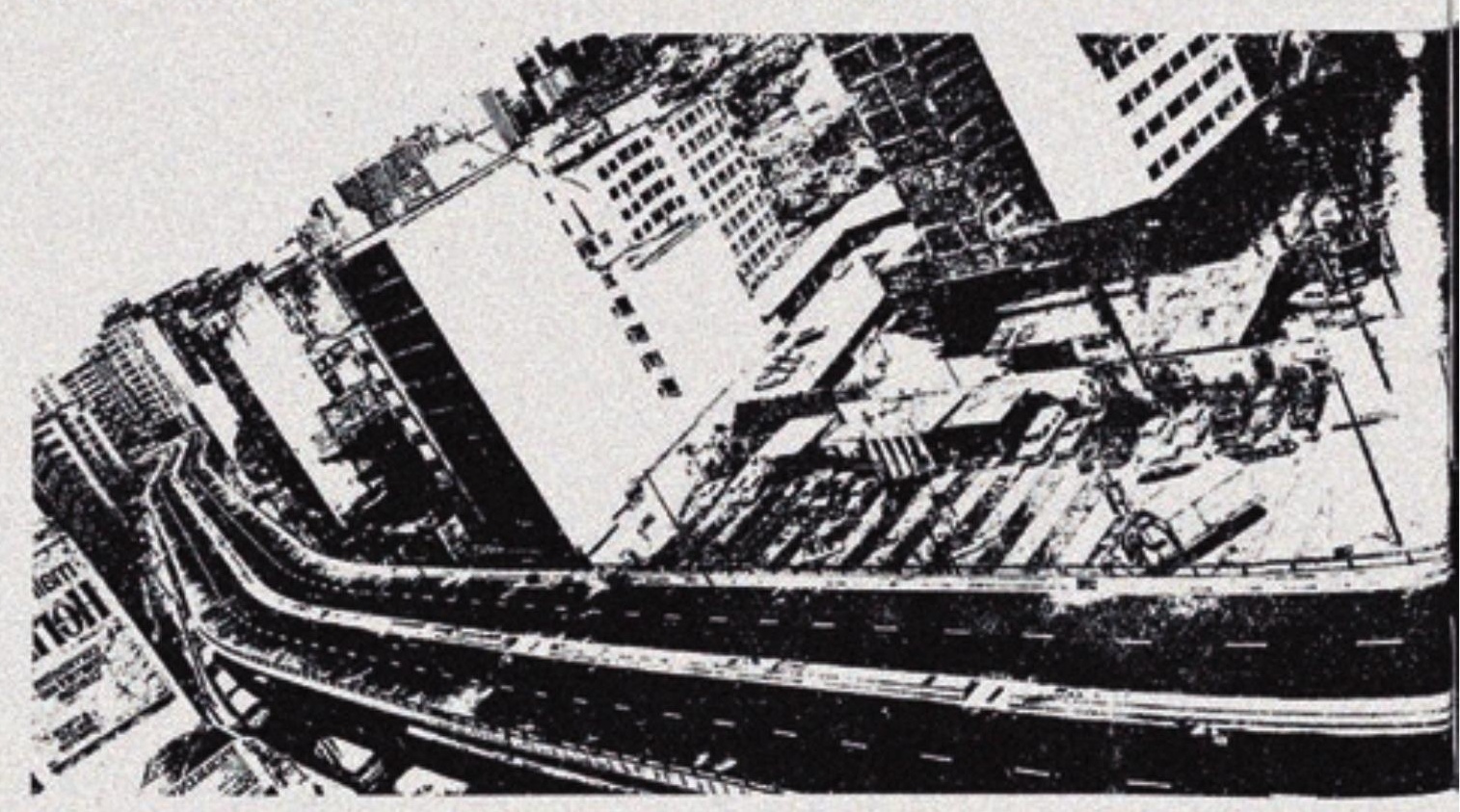


Vis Eleveda Presidente Arthar de Cesta e silea

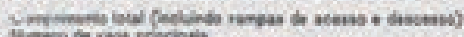
Wewo de was princigeis

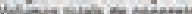

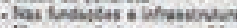

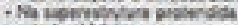

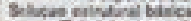

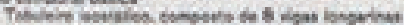

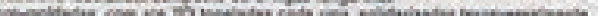

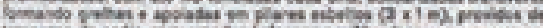

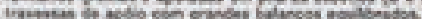

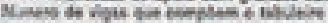

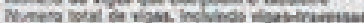

Kay das viga longludinais $\infty 00$ atro 000 ilis 20.

Alguhs autros rabalios de importincia da Mideoserivice.

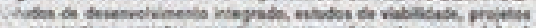

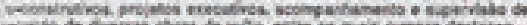

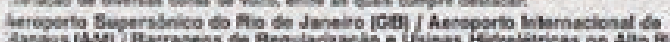

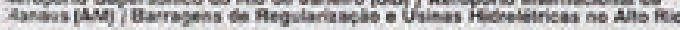

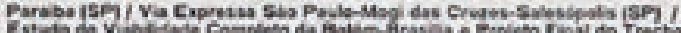

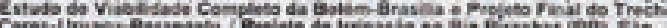

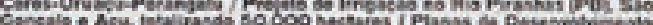

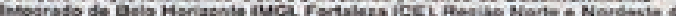

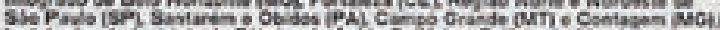

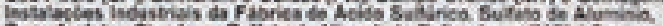

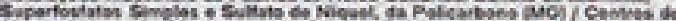

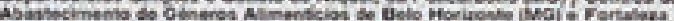

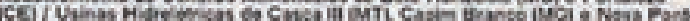

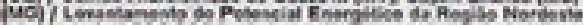

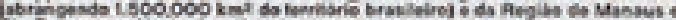
hio Bratica, no Norlio do pais.

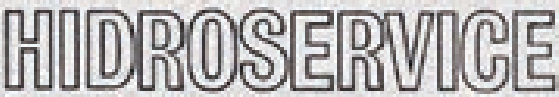

\section{Encesharia de Projetos Lode}

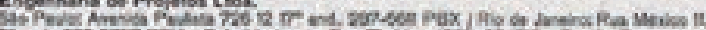

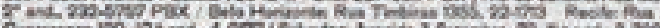

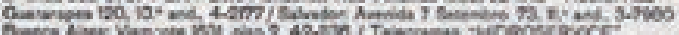

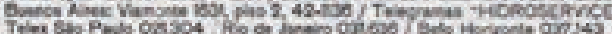

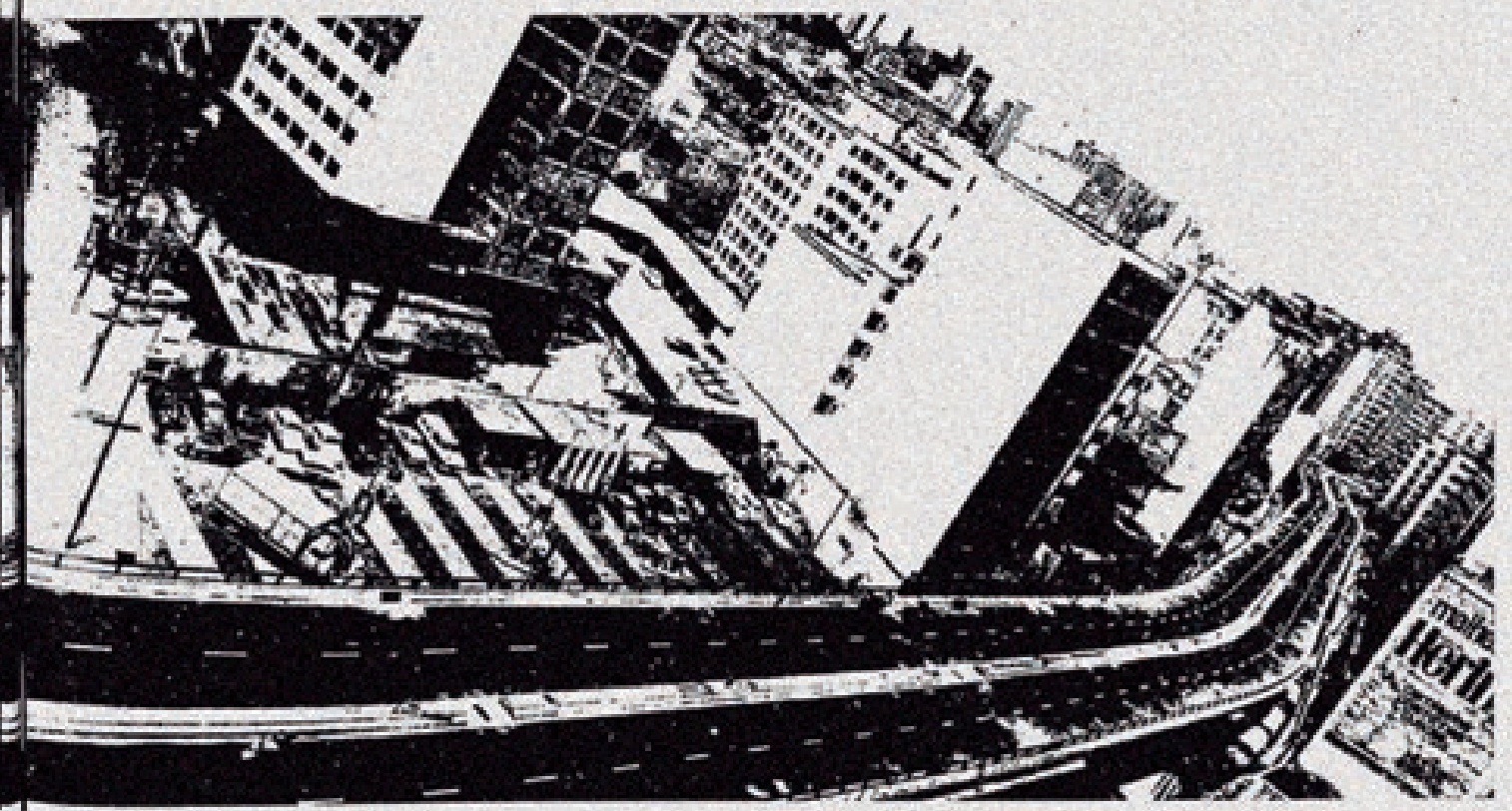


Fig. 1.2.8

Anúncio publicitário da empresa Mangels. O Estado de S. Paulo 1971.

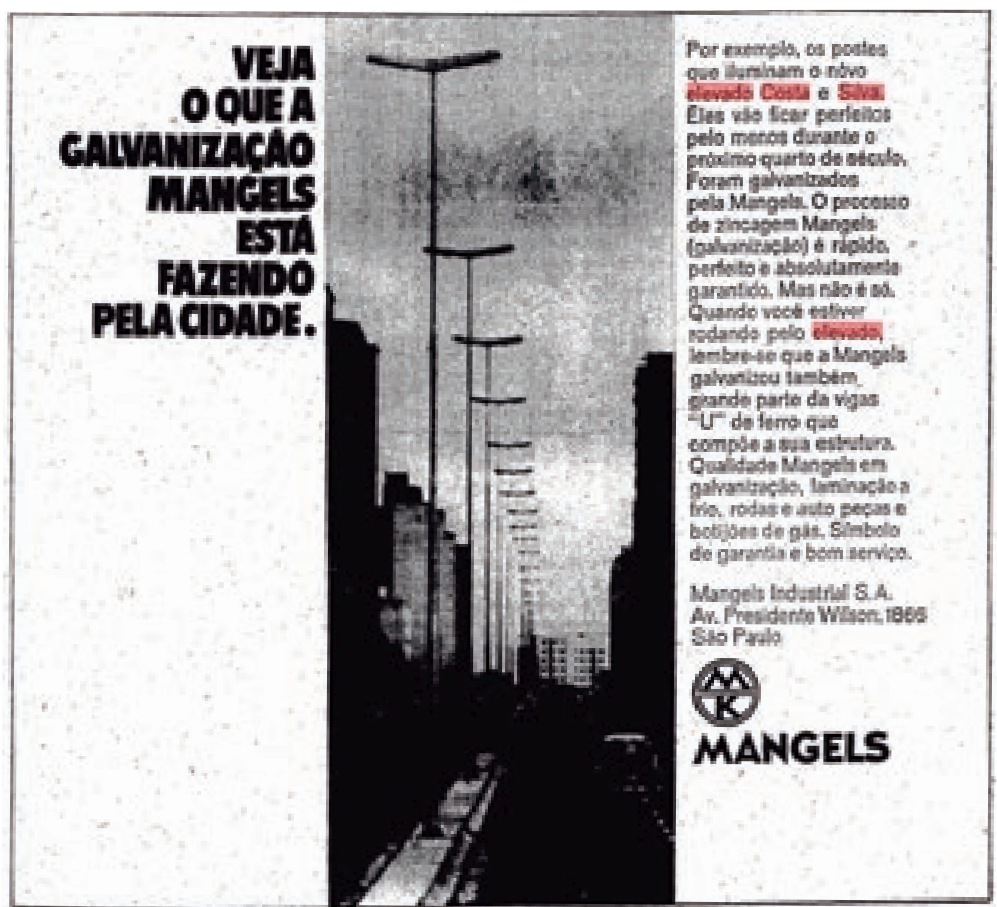

jornal o trabalho feito na galvanização dos postes de iluminação e das vigas da estrutura utilizadas ao longo da via expressa; aqui lê-se: "Quando você estiver rodando pelo elevado, lembre-se que a Mangels galvanizou também grande parte da (SIC) vigas "U" de ferro que compõe (SIC) a sua estrutura" (fig. 1.2.8). Em outro sentido a embresa Sabrico, revenderora e distribuidora da marca de automóveis Volkswagen, anunciava no jornal Estado de S. Paulo que o Minhocão tinha facilitado o acesso à empresa: "a via elevada Pres. Arthur da Costa e Silva parece ter sido feita de encomenda para levá-lo mais rápido até a porta da Sabrico (fig.1.2.9).

A construção do Elevado encontra paralelos em outras cidades do país e na própria cidade de São Paulo, conforme aponta matéria publicada no jornal Estado de S. Paulo em setembro de 1969, que enumerava uma série de projetos de vias elevadas e expressas e advertia: “a prefeitura está, agora, 


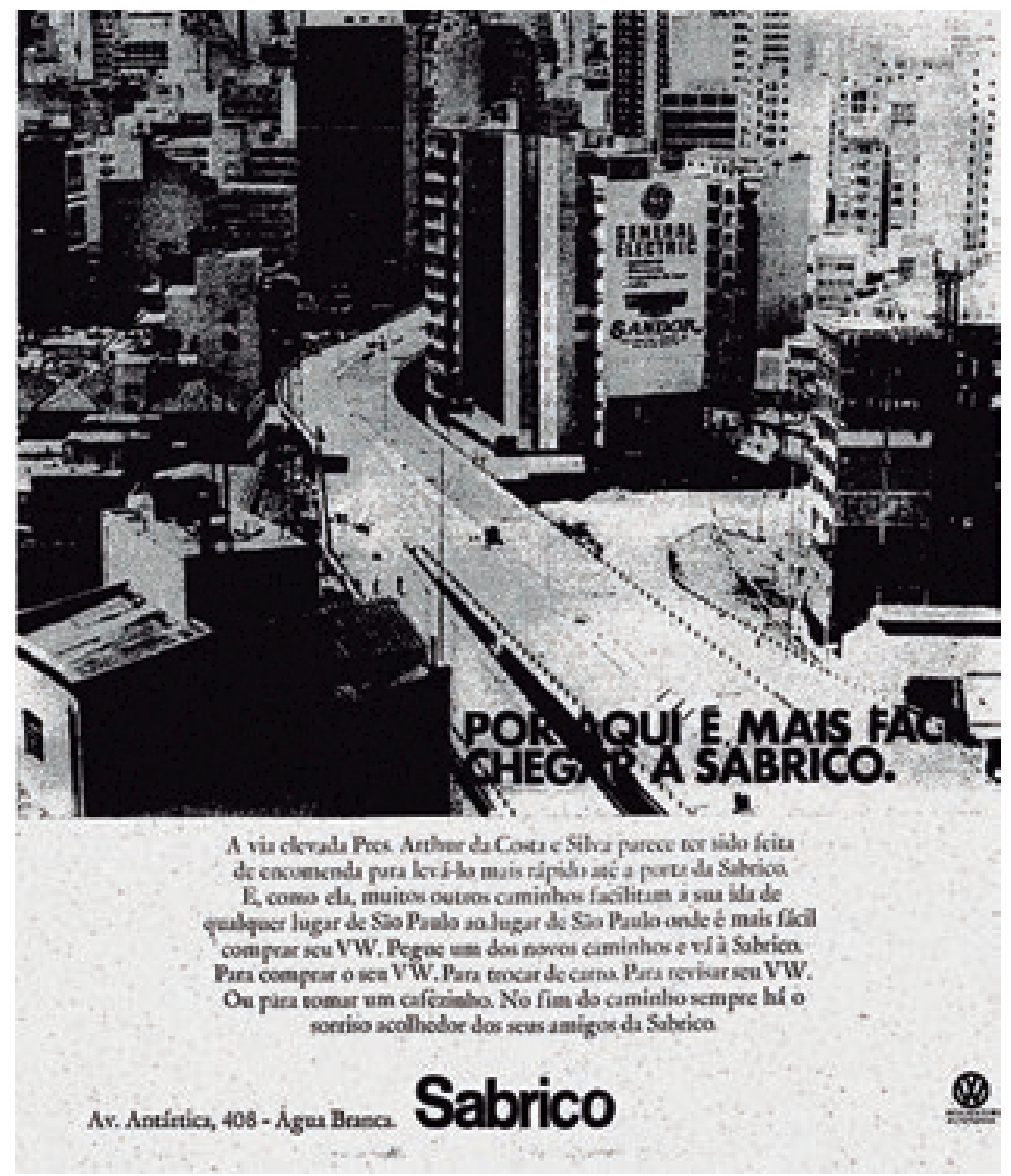

com mania de vias elevadas e expressas" ${ }^{14}$. No Rio de Janeiro verificamos a construção nos mesmos moldes da Avenida Perimetral - iniciada na primeira gestão de Francisco Negrão de Lima (1956-1958) e inaugurada em 1960 - e do Elevado da Bandeiras - construído na segunda gestão de Francisco Negrão de Lima (1965-1971) e inaugurado no mesmo ano do Elevado Costa e Silva.

O cruze no alto sobre o Centro traduz a forma como os planos, projetos e o próprio desenvolvimento urbano tratariam a região central da cidade, que passaria a partir da década de 1970 por
Fig. 1.2.9

Anúncio publicitário da empresa Sabrico. O Estado de S. Paulo, 1971.

14. O Estado de S. Paulo. Vias elevadas, a nova mania. São Paulo, 23 de setembro de 1969. 
um contínuo e intenso processo de esvaziamento populacional. $\mathrm{O}$ acesso ao automóvel pelas camadas médias-altas e altas permitiu que elas se afastassem da região central e se acomodassem em locais cada vez mais distantes, deslocando consigo a própria centralidade do Estado (Kara José, 2010, p. 19). Emblemático aqui a transferência das sedes do Governo Estadual e Municipal para fora da área central. Em 1955, a Prefeitura realocou sua sede situada na colina histórica para o recém-inaugurado Parque Ibirapuera, uma vez terminadas as comemorações do IV Centenário, e em 1964 o governo estadual saiu do Palácio dos Campos Elíseos para o Palácio dos Bandeirantes no Bairro do Morumbi. Transferências que ilustram tanto o abandono da região central pelas administrações públicas quanto a relevância dada ao transporte sobre rodas na distribuição dos usos da cidade.

Villaça (1998) associa o processo de esvaziamento do Centro ao deslocamento das atividades de comércio e serviço de alto valor agregado rumo sudoeste da cidade, principalmente o setor financeiro e os escritórios das grandes empresas nacionais e internacionais. Este processo de deslocamento, primeiro para a Avenida Paulista e na sequência para a então recém inaugurada Avenida Faria Lima (1970) é explicado pelo autor da seguinte maneira:

Foram os interesses de locomoção dessa classe que modelaram, a partir da década de 1970, uma parte dos territórios de nossas metrópoles, inclusive seus novos centros. A mobilidade territorial libertou as pessoas da prisão, do peso do espaço. [...] Essa classe, e o Estado por ela dominado, produziram então um espaço urbano em que elas podiam desfrutar ao máximo as opções que a liberdade espacial lhes oferecia. Isso ocorreu inclusive - em maior ou menor grau - com os centros principais de nossas metrópoles. Por isso, eles passaram, a partir dos anos 70, a assumir enormes dimensões e grande fragmentação; para isso precisaram de nova localização e de uma nova cidade, mais adaptada ao automóvel. Grandes estacionamentos, novas avenidas, vias expressas e rodovias. Elas permitiram que as classes de alta renda continuassem se deslocando para localizações mais afastadas. Entretanto (o controle do tempo 
de deslocamento é vital), apesar da maior mobilidade territorial, elas à medida que se afastavam procuravam minimizar o tempo de deslocamento ao centro, trazendo-o para sua direção (Villaça, 1998, p. 280).

Do ponto de vista da produção imobiliária, Kara José (2010, p. 90) também destaca algumas mudanças no quadro normativo e inovações na disponibilidade de crédito como fatores que ajudaram a transformar o tipo de lançamento e a localidade dos mesmos. Por um lado a limitação do coeficiente de aproveitamento do terreno (CA) e a fixação de cota mínima do terreno em $35 \mathrm{~m}^{2}$ prejudicaram a construção de quitinetes em detrimento de unidades maiores. Por outro a disponibilidade de linhas de crédito para construção e compra de apartamentos de classe média via $\mathrm{BNH}$ facilitaram o acesso ao capital desvalorizado para a incorporação e compra de unidades, acelerando o processo de produção imobiliária ${ }^{15}$. No mesmo sentido, também em 1964, foi instituída (Lei n. 4.59/1964) a forma condomínio "para qualquer padrão de empreendimento imobiliário, independente da quantidade de planos horizontais e do número de edificações propostas" (Rufino, 2012, p. 209). Lei (Lei n. 4.59/1964) que também regulamentou a forma de produção por incorporação, pela qual "a figura do incorporador torna-se responsável pela efetivação do registro de incorporação imobiliária, e adquire o direito de comercializar as unidades futuras antes de sua construção" (Rufino, 2012, p. 209).

Cabe ainda ressaltar aqui a inauguração do Shopping Iguatemi em 1966 na Avenida Faria Lima, considerado o primeiro shopping a ser inaugurado no Brasil. Em ressonância com o novo modelo de cidade rodoviarista, o shopping se tornou o emblema que distanciou os espaços comerciais do nível da rua, como outrora na Avenida São João. Para além de uma nova forma de conceber o espaço público eles tratariam de uma nova maneira de potencializar a comercialização do espaço por meio da locação de espaços comerciais.

15. Tendo em vista processo moroso de captação de mutuários anterior à instituição do BNH. 
O Elevado se constituiu como uma fratura na tessitura urbana: de uma lado ficou o bairro de Higienópolis (antigo Boulevard Burchard) e o de Santa Cecília e do outro a República e o Campos Elíseos, este último espremido contra a via do trem. Dois meses antes da inauguração do Minhocão, em dezembro de 1970, o jornal O Estado de São Paulo denunciava o esvaziamento que sua obra tinha desencadeado nos imóveis de seu entorno e as consequências trazidas por esse tipo de intervenção em outras cidades do mundo: "todo o submundo do crime e da prostituição, das populações marginalizadas reunido sob o agasalho de cimento do imenso viaduto"16.

O impacto sobre o entorno próximo foi lido imediatamente como drástico e, consequentemente, já em 1976, a via passou a ser fechada para os automóveis entre as $0 \mathrm{~h}$ e $5 \mathrm{~h}$ da manhã, buscando melhorar o conforto daqueles que habitam os apartamentos do seu entorno, por vezes localizados a uma distância de $5 \mathrm{~m}$ do leito carroçável da via elevada. No capítulo seguinte, veremos como esta estrutura associada ao centro "degradado" da cidade passou a receber novos usos.

16. O Estado de S. Paulo. Elevado o triste futuro da avenida. 01 de dezembro de 


\section{3}

\section{O Minhocão e o centro da cidade na virada do século XX: novas formas de apropriação do espaço}

A partir da crise da década de 1970, em contexto de desaceleração do crescimento pós-"milagre econômico", iniciaram-se os debates para a reestruturação econômica do Estado, que culminaram em uma série de alterações institucionais, responsáveis por atingir também a política habitacional. A inflação crescente descasada dos ajustes salariais, acompanhada pela elevação das taxas de desemprego e a informalização da economia, ao mesmo tempo que diminuíram a arrecadação via FGTS, aumentaram a inadimplência sobre os créditos contratados via SFH. Por fim, o choque dos juros americanos na crise do petróleo de 1979 disparou os valores das prestações e saldos devedores dos mutuários, comprometendo o equilíbrio fiscal do sistema. Os objetivos primeiros do conjunto, que regulamentou e deu segurança para o sistema de reajuste das prestações, entrou em colapso naquele período, resultando na extinção do $\mathrm{BNH}$ em 1986, no mesmo ano em que foi lançado o Plano Cruzado. Toda a regulamentação do crédito imobiliário passou então para o Banco Central e o Conselho Monetário Nacional e a Caixa Econômica Federal passou a ser o novo órgão administrador da política habitacional.

Com a economia desacreditada do final do governo militar, politicamente desgastado, e a extinção do $\mathrm{BNH}$, a política habitacional gestada e aprimorada ao longo de duas décadas passou para o limbo da desarticulação institucional na esteira da estabilização econômica. Os recursos captados via SBPE passaram a ser "instrumento da política monetária e da política de estabilização econômica, em detrimento do aporte de recursos para a produção habitacional" (Royer, 2009, p. 61). O controle da inflação se tornou a carta-programa dos governos que se sucederam ao lon- 
go do processo de democratização, tornando bandeira política a austeridade fiscal e a redução da máquina estatal, combinada com a liberalização da economia e a abertura do país para o mercado externo.

Neste contexto, a mobilização civil-popular ganhou força em diferentes frentes, que conquistaram em 1982 as eleições diretas para governador, em 1984 a massiva campanha para eleições gerais e em 1985, as eleições para prefeito nas capitais. Conforme aponta Affonso (2000) neste processo "os governos subnacionais passaram a ter um papel de destaque na Federação brasileira" (Affonso, 2000, p. 133) que resultou no que autor denomina de "descentralização pela demanda":
A luta dos estados e municípios pela descentralização tribu- tária teve início no final dos anos 1970, com a emergência da crise econômica e com o processo de redemocratização do país. Desta forma, a descentralização pode ser entendida, basicamente, como uma "descentralização pela demanda" (Affonso, 2000, p. 133).

\begin{abstract}
A Constituição de 1988 contribuiu para flexibiliar a ordem econômica independizando dela a ordem financeira, dando-lhe autonomia. Bercovici e Massoneto (2006) notam o início de uma série de reformas institucionais empreendidas para alterar o padrão de financiamento do Estado e nortear o desenvolvimento do sistema financeiro nacional a partir de então. Foi na separação entre a constituição financeira e a constituição econômica, que se traçaram estes princípios:
\end{abstract}

\footnotetext{
A constituição financeira passou a ser interpretada e aplicada como se fosse 'neutra', meramente processual, com diretrizes e lógica próprias, separada totalmente da ordem econômica e social, esterilizando, assim a capacidade de intervenção do Estado na Economia. Separada da constituição financeira, a constituição econômica de 1988 foi transformada em mera “norma programática” (Bercovici, et al, 2006, p. 67).
} 
As medidas de controle da hiperinflação do Plano Collor culminaram no confisco das cadernetas de poupança em 1990 via Banco Central, restringindo quase que totalmente a disponibilidade de recursos que antigamente alavancavam o Sistema de Crédito Imobiliário nacional. Os efeitos dessa medida, objetivamente no financiamento habitacional dos empreendimentos lançados naquela época e subjetivamente na confiança do cidadão com a economia, teriam efeitos importantes ao longo de, ao menos, uma década no setor habitacional. Deste processo surgiria o Movimento Nacional do Mutuários na defesa contra os elevados reajustes das prestações no bojo das mobilizações que derrubaram o governo militar.

Se, por um lado, durante o governo Fernando Henrique Cardoso, a estruturação de uma política nacional de habitação voltou à pauta político-institucional por meio da criação da Secretaria da Política Urbana no Ministério do Planejamento, por outro o contexto macroeconômico de ajuste fiscal e austeridade mantiveram congelados os investimentos públicos. A taxa referencial e os juros altos associados à inflação, controlada do período FHC, desencorajaram tanto as atividades do setor produtivo, preferindo investimentos com taxas elevadas de retorno nos negócios financeiros garantidos pela Selic alta, quanto a compra de imóveis cujas parcelas eram reajustadas mensalmente pelos mesmos mesmos juros.

Neste período, é importante destacar o lançamento do Programa Carta de Crédito em 1995, "carro-chefe" da concessão de créditos imobiliários via FGTS a partir daquela data, principalmente para o indivíduo pessoa física. O programa passou a incorporar o financiamento para ampliação ou reforma da unidade habitacional e até para compra de materiais de construção, injetando recursos neste setor da economia pouco explorado nos períodos anteriores.

As empresas da construção imobiliária tiveram que buscar soluções alternativas para dar continuidade aos negócios neste novo contexto de escassez de crédito público. O autofinanciamento, "que se define pela antecipação de capital pelo usuá- 
rio para a produção, eliminando a intermediação financeira" (Castro, 1999, p. 135). reapareceu como forma das empresas viabilizarem a atividade de incorporação. Com isso, também reapareceram as obras contratadas a "preço fechado" que vimos no primeiro item, a "preço de custo" ou "por administração", regimes de construção regulamentados pela Lei do Condomínio de 1964 (Lei n. 4.591), que permitiu maior envolvimento do mutuário nos gastos da obra e consequentemente uma redução importante nos preços de compra dos imóveis. Como afirma Castro:

Em 1992 incorporadoras, construtoras e corretoras procuraram garantir a continuidade dos negócios com promoções, lançando planos de financiamento facilitados e simplificados pelos agentes de vendas que eram fundados na captação de recursos de consumidores a serem aplicados diretamente na produção. Eram denominados planos de autofinanciamento por meio dos quais o promotor centralizava e integrava os recursos financeiros dos usuários antecipados à produção. Estes planos combinavam valores de entrada reduzidos e um financiamento independente do $\mathrm{SFH}$ com prestações atraentes para o perfil do consumidor de classe média-baixa e média, ou seja, aqueles na faixa de oito a quinze e de quinze a trinta s.m. respectivamente. (Castro, 1999, p. 136).

Na década de 1990, o tamanho e a distribuição dos empreendimentos tiveram que se adequar então à escassez de recursos. Em São Paulo os conjuntos de grande porte foram implantados majoritariamente em regiões pericêntricas, junto ao centro expandido tradicionalmente trabalhado pelo mercado, em grandes glebas que permitiam a implantação de bolsões de estacionamento descoberto, solução que evitava os elevados custos da escavação em subsolos. Castro (1999) destaca que as empresas passaram, neste contexto, a controlar, fiscalizar e otimizar mais intensamente os serviços realizados no canteiro criando novos padrões para os lançamentos imobiliários. Como resultado desse controle minucioso dos gastos via novas práticas gerenciais, veri- 
ficamos uma padronização e normatização de serviços nas obras e o uso maior de componentes industrializados, diminuindo os serviços realizados no canteiro. Os empreendimentos realizados via autofinanciamento neste período, em média, conseguiram encurtar o tempo de obra de 20 para 14 meses (Castro, 1999, p. 197) e reduzir os preços das unidades sobre aqueles praticados durante o período do $\mathrm{BNH}$.

Cabe aqui discutir um dos empreendimento da incorporadora e construtora Encol realizado às margens do Elevado chamado "Edifício Avant Place Downtown". Incorporadora reconhecidamente inovadora para os anos nos quais trabalhou, ousou colocar o centro no próprio nome do lançamento no momento em que o mercado buscava se associar mais aos bairros de classe média-alta do que às áreas centrais ditas "degradadas". O edifício se destaca da média dos lançamentos do começo da década de 1990 pela sua envergadura - 256 unidades lançadas em um único edifício - e local no qual foi implantado - no bairro dos Campos Elíseos. Fonseca (2000) detalha novos procedimentos que a incorporadora Encol implantou na época e que contribuíram para projetar a empresa em um crescimento vertiginoso, raro no cenário de austeridade fiscal e escassez de financiamentos: como novos "critérios de avaliação de projetos", normatização, padronização e um novo arranjo do canteiro, dividindo as obras não por empreendimento, mas por serviços (Fonseca, 2000, p. 93) para justamente reduzir os custos e otimizar os gastos em um período de escassez de crédito após a extinção do BNH em 1986. Época analisada por Castro (1999), na qual um grande número de empreendimentos buscou na fórmula do autofinanciamento a forma para financiar a sua produção, similar ao mecanismo que levou a produção de quitinetes na década de 1940 e 1950.

No sentido de contribuir com a intensificação do uso do solo e baratear o produto imobiliário, em 1992 foi lançado o Decreto Municipal n. 31.60, que regulamentou os parâmetros e índices incentivados para a produção de Habitação de Interesse Social (HIS). Com coeficiente de aproveitamento até 4 vezes da área do terreno, os empreendimentos deveriam ter no máximo um 
banheiro, uma vaga e área máxima de $72 \mathrm{~m}^{2}$, definindo um novo padrão de habitabilidade, que serviu de referência para os empreendimentos que se sucederam.

O abandono do centro da cidade pela classe média-alta e alta, associado ao processo de esvaziamento populacional deu espaço para o fortalecimento de outra identidade para o centro, que denominamos, de acordo com os trabalho de Kara José (2010) e Villaça (1998) de "popular". Em termos quantitativos, deste processo fazem parte a diminuição total do número de empregos já entre 1970 e 1975 (Villaça, 1998, p. 271) e do número de moradores a partir da década de 1980 (Silva, 2011, p. 75). Em termos qualitativos, devemos destacar a desaparição e troca das antigas butiques colina histórica pelo comércio popular (Villaça, 1998, p. 283) e o aumento da população encortiçada, que passou a representar, aproximadamente, um quarto do total dos moradores da região central (Silva, 2011, p. 75).

Se por um lado o processo de abandono e consequente esvaziamento populacional desencadeou um processo de ocupação dos imóveis vazios pela população de baixa renda, por outro desencadeou um processo de deterioração ambiental. Seja por meio de ocupações irregulares organizadas, ou não, ou por meio do encortiçamento dos imóveis, a população de baixa renda viu na ocupação desses imóveis vazios oportunidades solventes de moradia próxima a uma boa rede de serviços básicos. Podemos destacar aqui a ocupação do próprio Edifício Martinelli, localizado na extremidade da colina histórica no eixo da Avenida São João (Villaça, 1998, p. 282). Por outro lado, o processo de deterioração física do patrimônio construído se potencializou graças à implantação de pontos finais de transporte coletivo e à construção das linhas norte-sul e leste-oeste do metrô, que transformaram o centro num espaço de intenso fluxo entre modais de transporte metropolitano:

Simultaneamente, o acesso das camadas populares ao Centro foi favorecido com a ampliação dos sistemas de transporte coletivo, a partir da década de 70. Fizeram parte destas ações a implantação das linhas norte-sul (inauguradas entre 1974 e 
1978) e leste-oeste (inauguradas entre 1979 e 1988) do Metrô, que, ao se cruzarem na Sé, assumiram o núcleo histórico da cidade como foco principal da rede do transporte metropolitano; a concentração de pontos finais de diversas linhas de ônibus da cidade em praças como a da Sé, Patriarca, Ramos de Azevedo; os grandes terminais de ônibus, do Parque Dom Pedro II, Praça da Bandeira e Princesa Isabel. Segundo análise de Nakano et al., além do tráfego, a deficiência na integração entre esses diversos modos de transporte coletivo passou a gerar um fluxo intenso de pedestres que se deslocam entre terminais, estações e pontos finais; isso contribuiu para a alteração do perfil dos usuários: do comércio, serviços das ruas da região, inclusive para a atração do grande número de camelôs (Nakano; et al, 2004, p. 138 apud Kara José, 2010, p. 25).

Como afirma Villaça, "foi o abandono que fez com que os edifícios se deteriorassem, pois não compensava mais mantê-los" e não o contrário; "não foi a deterioração que provocou o abandono" (Villaça, 1998, p. 282). Este processo ocasionou aquilo que o autor coloca como uma cisão entre o centro nobre e o popular, dado que o deslocamento da centralidade em São Paulo rumo sudoeste não se deu na forma de um espraiamento da centralidade, conforme verificado em outras cidades, mas da criação atomizada de vários centros especializados voltados para a alta renda, separados do centro "original":

A partir da década de 1970 houve um salto, uma descontinuidade nesse deslocamento espacial, de maneira que as duas partes - a nobre a popular - não eram mais duas metades contíguas de um único centro, mas dois centros separados um nobre e outro popular. (Villaça, 1998, p. 282).

O centro passou, então, a ser qualificado nos meios de comunicação como um espaço "deteriorado" ou "decadente", qualificações que velam o processo de abandono que buscamos descrever, no qual paulatinamente se justificaria o surgimento de projetos de "revitalização" ou "requalificação". Como personagem atuante nesta trama, o Elevado encarnou essa cisão entre o centro nobre e o popular, uma linha concreta entre os bairros 
nobres de Higienópolis e Pacaembu e o centro antigo. Situação comumente traduzida como "fratura" ou "cicatriz" no tecido urbano.

Diversos autores (Kara José, 2010; Nobre 2009; Shimbo 2013; Silva 2007, 2011) tratam das iniciativas lançadas pelo poder público, a partir da década de 1970, para "revitalizar" o centro da cidade. $\mathrm{O}$ tom do diagnóstico que desencadearia e justificaria tais iniciativas na região mudou ao longo do tempo, oscilando entre "degradação ambiental", "desvalorização" ou "decadência", mas segundo Kara José os critérios que têm sido adotados para qualificar a área desta forma se alinham na seguinte leitura:

(ii) a reduzida dinâmica imobiliária: falta de lançamento de edifícios residenciais e de serviços; (ii) a presença de edifícios residenciais e comerciais desocupados e deteriorados; (iii) instalações industriais desativadas em grandes lotes; (iv) valores relativamente baixos dos aluguéis comerciais e residenciais; (v) a redução da população, especialmente de classe média, aliada à permanência de população de baixa renda nos cortiços. (Kara José, 2010, p. 31).

Segundo Nobre, os novos projetos oscilavam entre a "renovação" urbana e a "requalificação" e tratavam das tentativas de reversão do processo de esvaziamento populacional da área central. Apesar dos projetos começarem a ser realizados já a partir da década de 1970, com ênfase nas questões do patrimônio histórico, foi a partir de década de 1990 que eles ganharam destaque e intensidade, resultando em uma sucessão de projetos novos e diversos que vieram a ser anunciados a cada nova gestão municipal a partir da Gestão da Luiza Erundina (1989-1992) até os dias de hoje. Projetos que evidenciam uma transformação na forma como o interesse público passou a encarar esta região anteriormente por ele abandonada.

Apesar das tentativas de trazer investimentos e habitantes das camadas médias-altas para o centro, o processo de reocupação desta regisão se deu de forma pioneira pelos movimentos de moradia, sem o acompanhamento de políticas públicas. A ocupação 
de edifícios abandonados para habitação de baixa renda constituiu base material para a organização de alguns destes movimentos, responsáveis pela luta por condições mínimas de habitação no contexto das discussões da Reforma Urbana (Kara José, 2010, p. 28). Neste sentido, o movimento de moradia "Unificação das Lutas de Cortiços" foi constituído em 1990 na busca por organizar a população para pressionar o poder público por melhores condições de habitação. Também neste contexto foi aprovada da Lei Moura (Lei 10.928/91), que normatizou as condições mínimas de habitação para os cortiços, à parte das outras leis edilícias e exigiu do poder público a fiscalização, articulação e a cooperação entre as diferentes esfera de governo para a "recuperação, renovação e regularização de áreas com concentração de cortiços" (Cidade de São Paulo, 1991a).

A gestão de Luiza Erundina marcou uma mudança na forma como a administração pública encarou a região central, simbolicamente representada pela transferência da sede da Prefeitura para o Parque Dom Pedro e a reforma do Vale do Anhangabaú, ambos em 1992. Os primeiros projetos desta gestão focaram na "melhoria da paisagem urbana" e "preservação do patrimônio" (Kara José, 2010, p. 28). Desta época, devemos destacar também a Operação UrbanaAnhangabaú (Lei n. 11.090/91), precursora das Operações Urbanas Consorciadas, e o surgimento da Associação Viva o Centro (1991), apoiada pelo Bank Boston. A década de 1990 é considerada uma fase de "transição" entre a Constituição Federal recém-aprovada e o Estatuto da Cidade (2001) (Bonduki, 2017, p. 110) devido a gestões como a da Luiza Erundina que trouxeram inovações no campo da política urbana antes mesmo da sua regulamentação a nível federal, assunto que discutiremos no próximo capítulo.

A partir desta gestão, entre a década de 1990 e a primeira década dos 2000, com base nos autores citados, podemos elencar um grande número de planos que foram sendo elaborados para a região central e que não cabem neste trabalho maior aprofundamento: Procentro (1993), Programa Ações Locais (1995), Lei de Fachadas (Lei 12.350/97), Operação Urbana Centro (Lei n. 12.349/97), Programa de Atuação em Cortiços (PAC/1998), 
Programa Reconstruir o Centro (2001), Programa Morar no Centro (2001), Projeto de Revitalização do Bairro da Luz do Programa Monumenta (2002), Programa Ação Centro (2004), Procentro (2005), Lei de Incentivos Seletivos (2005), Concessão urbanística "Nova Luz" (2009). Apesar do grande número de projetos, Nobre (2009) afirma que nenhum deles foi capaz de realizar uma transformação significativa para a região central:

\begin{abstract}
Dessa forma, apesar dos 30 anos de planos e projetos para a área central, as poucas ações efetivas do poder público e do mercado não foram suficientes para alterar significativamente as características da região - nem para a erradicação das áreas ditas 'deterioradas', nem para sua reabilitação e, muito menos, para reverter o processo de produção do espaço metropolitano. (Nobre, 2009, p. 229).
\end{abstract}

Apesar do centro da cidade ter sido sempre espaço no qual os cargos na administração pública representam uma porcentagem expressiva do total de empregos (41\% em 1991 (Kara José, 2010, p. 68)), o retorno da sede do governo municipal junto de alguns setores da administração estadual para o centro da cidade significou uma peça importante na restauração e conservação do patrimônio construído. Kara José levanta que na data da pesquisa (2010) ao menos 50 prédios da região central estavam ocupados pela administração pública, dos quais 40 não o estavam antes de 2004 (Kara José, 2010, p. 171). Deste processo resultaria também a restauração do Edifício Martinelli (2002) para o qual se mudariam algumas da principais secretaria da prefeitura, simbolizando uma etapa mais na história do edifício: primeiro arranha-céu da cidade transformado em cortiço na década de 1970 e restaurado no começo do século $\mathrm{XX}$ para abrigar o retorno da gestão pública para o centro ${ }^{17}$. A este processo podemos somar a vinda de mais trabalhadores

17. Mais recente ainda podemos citar a concessão da cobertura do mesmo para a iniciativa privada para estabelecimento de um café-mirante, faceta do novo programa de "revitalização" do centro da gestão Bruno Covas chamado "Triângulo SP". Programa que pretende "qualificar o espaço, configurando-o como um produto turístico internacional" (Cidade de São Paulo. Projeto Triângulo SP vai revitalizar Centro Velho de São Paulo. 27 de dezembro de 2018 - link para site na bibliografia). 


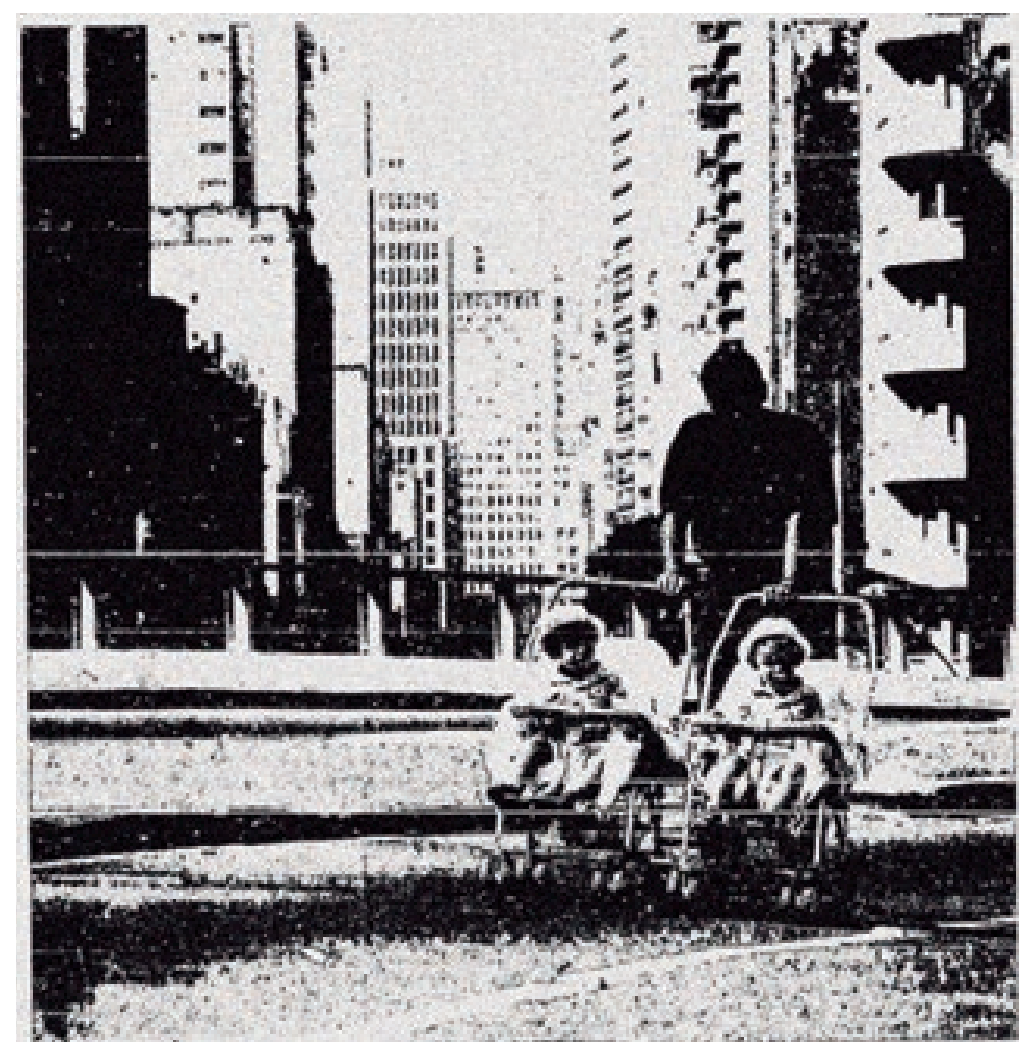

Fig. 1.3.1 Notícia

"Minhocão aberto para carrinho de bebê".

Folha de S. Paulo, 1990.

das classes médias-altas e com eles a aproximação de outros serviços de apoio e o (re)surgimento de comércios com "perfil Jardins" (Kara José, 2010, p. 84).

Também na gestão Erundina, por meio de um projeto piloto que se tornaria definitivo, o horário de fechamento para o trânsito de carros do Elevado Costa e Silva se estendeu da 0h para as $21 \mathrm{~h} 30$ e das 5 h para as 6 h $30^{18}$, completando entre as 21 h30 e às 6 h30 oito horas de espaço fechado para o trânsito de veículos, além dos domingos e feriados. Horários que permitiriam um uso de recreação novo no espaço que antes era praticamente inexistente dado o horário de fechamento para veículos restrito às madrugadas, quando poucas pessoas circulam. É emblemático deste processo a imagem veiculada na notícia do jornal Folha de S.

18. Folha de S. Paulo. Minhocão fecha às $21 \mathrm{~h} 30$ e abre às $6 \mathrm{~h} 30$. São Paulo, 24 de novembro de 1989, caderno cidades. 


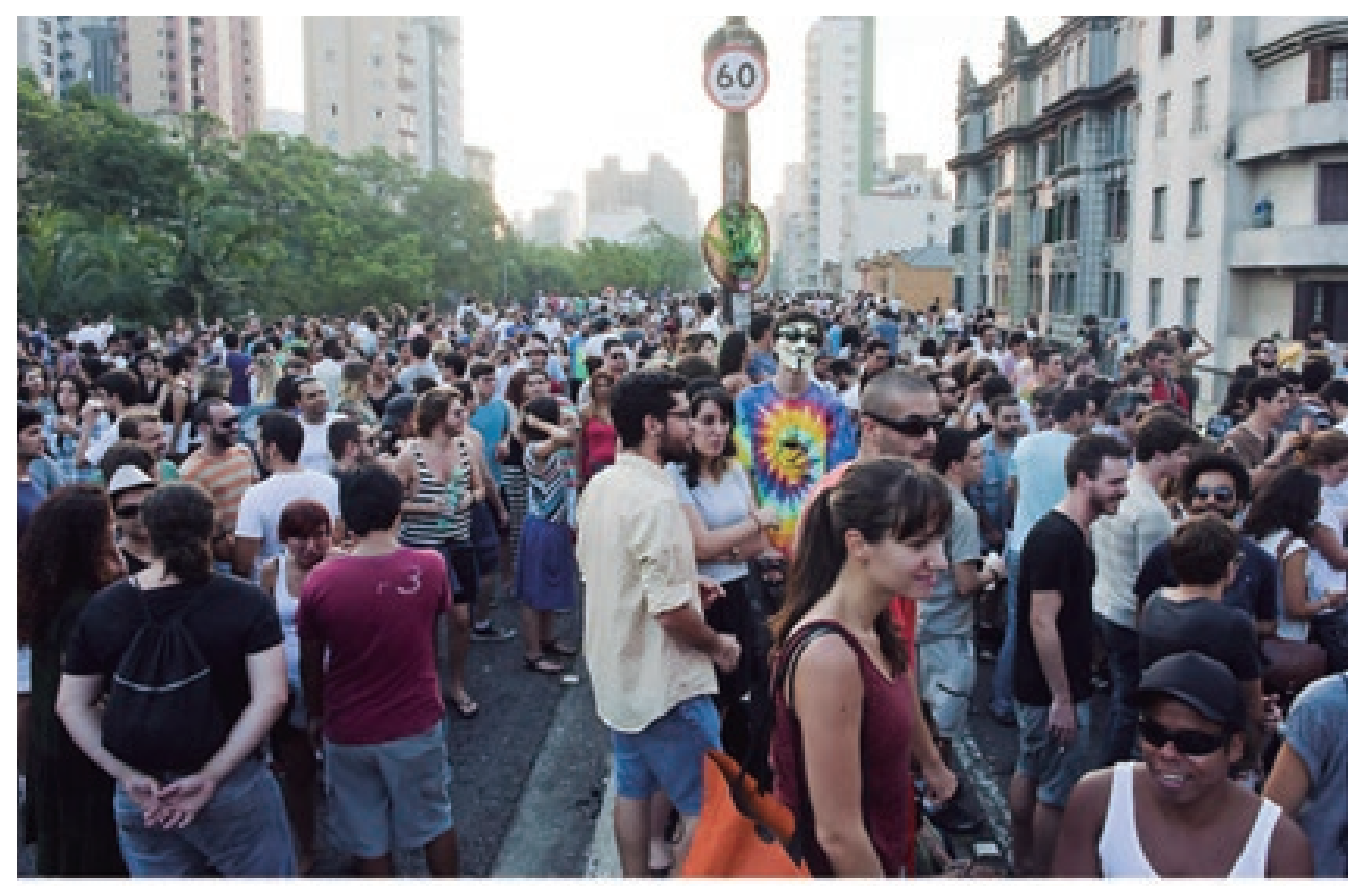

Fig. 1.3.2

Fotografia Festival

Baixo Centro.

Folha de S. Paulo, 2012.
Paulo intitulada "Minhocão aberto para carrinho de Bebê" (fig. 1.3.1), imagem outrora absurda que aproxima o Elevado a um carrinho de bebê.

No contexto dos novos usos que o Minhocão e o centro viriam a experimentar, certos episódios se destacam, principalmente a partir dos anos 2000. O primeiro é a fundação do bloco carnavalesco Agora Vai em 2004, que, apesar de não ser primeiro a bloco a desfilar por cima do Elevado, é emblemático pela envergadura do desfile que realizou aqui até 2015. Na sequência, devemos destacar a inauguração da Virada Cultural em 2005, evento cultural realizado em alguns pontos de cultura distribuídos pela cidade ao longo das 24h de um final de semana, entre eles o Minhocão.

Posterior, é o surgimento das festas de rua, como a Voodoohop, fundada em 2009, que em depoimento para o portal de entretenimento e notícias "Guia da Semana" seu fundador, Thomas Haferlach declarou: 
pessoas da noite e ajudamos a criar esse movimento de reocupar o centro. A transição lógica disso foi que a gente começou a fazer eventos de graça ao ar livre. São Paulo aproveita muito pouco do espaço público e começamos a mostrar lugares no centro pras pessoas. Fomos um dos primeiros coletivos a fazer festa no Minhocão e na praça São José Gaspar (Guia da Semana, Conheça o Coletivo Voodoohop) ${ }^{19}$.

Alguns anos mais tarde, em 2012, sugeriria o Festival Baixo Centro, que sustentava o lema "as ruas são para dançar" e cuja primeira edição foi realizada no Minhocão e seu entorno. $\mathrm{O}$ evento organizado de forma autônoma chamava iniciativas da sociedade civil para "ressignificar" o espaço público. Na imagem abaixo (fig. 1.3.2) constatamos o público jovem, de maioria branca, que viria a ocupar os espaços do centro neste processo de ocupação via eventos e festas.

Do ponto de vista da produção imobiliária no final do século $\mathrm{XX}$ devemos destacar a importância que ganham no centro da cidade os empreendimentos realizados por meio da reforma de edifícios existentes chamados no jargão do mercado imobiliário de retrofits, viáveis nesta região dada a concentração de edifícios de apenas um único dono ou família. A partir da década de 1990 até a data da publicação do trabalho, Kara José elenca 41 empreendimentos deste tipo voltados, na sua maioria, para o segmento popular (Kara José, 2010, p. 202). Sobre as empresas empreendedoras, a autora destaca:

\footnotetext{
São empresários de menor porte, que trabalham com um capital menor e atendem uma demanda de menor poder aquisitivo - um perfil de investidor diferente daquele enfocado por instrumentos como a Operação Urbana Centro, por exemplo. Eles estão ocupando um nicho de mercado que até agora estava vago, e que é típico do Centro atual: a reabilitação de edifícios ociosos para população de renda abaixo da média (Kara José, 2010, p. 227).
}

19. Andrade, Juliana. Conheça o Coletivo Voodoohop. Guia da Semana, 20 de fevereiro de 2014 (link para site na bibliografia). 
Em suma, podemos identificar que o retorno ao centro se deu por três vertentes: a primeira pela ação do Estado, principalmente pela volta de segmentos da administração pública e pela implantação de equipamentos de lazer, a segunda pelos segmentos da população de baixa renda, que encontraram oportunidades solventes de aceder à moradia bem servida de infraestrutura, e a terceira pelos eventos e a oferta de atividades de cultura, processo que aproximou o centro do público jovem, com outras demandas pelo espaço.

No entanto, foi somente no dia 11 de abril de 2011, que a Agência Estado publicou o artigo intitulado "Depois de 30 anos, aumenta a população no centro de SP", no qual se noticiou uma reversão da tendência dos 30 anos anteriores, de esvaziamento populacional das áreas vinculadas ao centro histórico da cidade. Essa nota publicou os balanços dos últimos censos do IBGE (Instituto Brasileiro de Geografia e Estatística) nos quais se identificava uma queda de $14 \%$ no número de moradores nesses locais no censo de 1991 e $23 \%$ no de 2000 , para finalmente noticiar a reversão tímida dessa tendência no censo de 2011. No próximo capítulo, analisaremos as mudanças ocorridas no século XXI. 


\section{capítulo 2}

\section{Estratégias para a transformação da cidade e do Minhocão: (des)regulamentação e impulsos virtuais}

Este capítulo procura analisar os marcos regulatórios da política urbana que regulam a nível municipal a ocupação do solo no entorno do Minhocão. A partir de dois níveis de análise diferentes discutimos primeiro, de forma ampla, os Planos Diretores da cidade de São Paulo especificamente no que tange a região em questão. Segundo, com mais profundidade, especificamente as leis, planos e projetos para o Minhocão que foram sendo anunciadas pelo poder público ao longo do século XXI. Permeando esta discussão, analisamos a articulação entre setores da sociedade que encabeçam o debate sobre o futuro do Elevado na busca por entender a complexa imbricação de agentes na construção de um consenso em torno da transformação da estrutura.

No primeiro item, analisamos os Planos Diretores de São Paulo do começo do século XXI a partir dos paradigmas os fundaram e enquanto discursos refletidos em "instru- 
mentos urbanísticos" que buscam nortear a ocupação do solo da cidade. Analisamos inicialmente o percurso que foi percorrido desde a discussões em torno da luta pela reforma urbana no contexto da constituinte de 1987, passando pelo Estatuto da Cidade, até a promulgação destes Planos. Apontamos aqui como eles se constituem de um lado como pacto social e do outro, como ideologia de crescimento. Buscamos levantar alguns pontos relevantes para entender os caminhos pelos quais eles propõem a transformação urbana, especificamente no entorno do Minhocão, discutindo algumas contradições no seu discurso. Cabe neste item discutir o contexto no qual foi institucionalizada, no Plano Diretor de 2014, a desativação gradual do Minhocão para o trânsito de veículos.

No segundo item, analisamos primeiro as organizações da sociedade civil envolvidas no debate em torno da transformação do Elevado, organizações que disputam narrativas hegemônicas sobre o seu futuro. Na sequência, analisamos a atuação dos vereadores envolvidos na elaboração de projetos de lei que também visam a transformação da região, seja pelo alinhamento com o seu programa de governo, seja com mero fim eleitoral, tendo em vista a dimensão midiática que o assunto tomou. Verificamos aqui a articulação entre sociedade civil e poder público enquanto a construção de uma rede ou coligação a favor da transformação da estrutura.

Finalmente, no último item faremos um levantamento e análise das leis, planos e projetos que foram elaborados ou apenas anunciados pelo poder público para o Elevado e seu entorno, nas instâncias legislativas e executivas. Destacamos quais foram os principais atores que deram andamento para tais projetos, quais são as justificativas que motivaram a sua elaboração e as transformações que eles promoveram no espaço. Discutimos como essas leis, planos e projetos contribuem na construção de uma imagem virtual apropriável para a construção de um consenso em torno da transformação da Estrutura. 


\section{1}

\section{Novos marcos regulatórios das políticas urbanas no Brasil e a sucessão de Planos Diretores de São Paulo no século XXI}

Para iniciarmos a análise dos Planos Diretores da cidade de São Paulo elaborados no século XXI, que na versão de 2014 incluiu a desativação gradual do Minhocão para o trânsito de veículos motorizados, faremos uma breve digressão sobre o surgimento do Estatuto da Cidade (2001) que antecede e é peça estruturante desses planos. Entendemos aqui que os Planos Diretores desta capital surgiram em um contexto mais amplo de discussões iniciadas a partir da década de $1960^{20}$ que tratam da reforma urbana e que ganharam um novo impulso na constituinte de 1987.

Conforme levantamos anteriormente, a crise econômica, que levou à desestruturação do BNH e de forma mais ampla ao desabamento dos alicerces que sustentavam até então o regime autoritário, incentivou a mobilização de segmentos da sociedade envolvidos na luta pela reforma urbana ${ }^{21}$. O intenso crescimento populacional das cidades associado ao crescimento acelerado de loteamentos populares nas periferias à margem da intervenção Estado envolveu um amplo leque de entidades da sociedade civil ${ }^{22}$ na luta por terra urbana e por condições mínimas de habitação para os segmentos de baixa renda. Como afirma Bonduki (2017):

20. Nos referimos ao Seminário de Habitação e Reforma Urbana realizado em 1963.

21. Discussões iniciadas décadas antes em torno das "reformas de base" do governo João Goulart (1961-1964) deposto pelo golpe militar.

22. Entidades associadas à Igreja Católica (Comunidades Eclesiais de Base e a Comissão Pastoral da Terra), entidades representantes de classe (sindicatos e institutos de arquitetura) e núcleos de pesquisa de várias universidades. 
[...] a luta em torno da função social da propriedade não era um debate teórico. Na prática buscava-se alternativas ao modelo de política urbana e habitacional da ditadura, questão que mobilizou e articulou entidades profissionais e acadêmicas, movimentos sociais, ONGs e sindicatos na perspectiva de uma atuação conjunta (Bonduki, 2017, p. 92).

Neste contexto, a mobilização civil-popular ganhou força em diferentes frentes, que conquistaram em 1982 as eleições diretas para governador, em 1984 a massiva campanha para eleições gerais e as eleições para prefeito nas capitais em 1985.

A Assembleia Nacional Constituinte foi formada em 1987, neste contexto de intensa mobilização civil, sob um regimento "inovador" (Bonduki, 2017, p. 93), que além de criar mecanismos de participação popular - por meio de audiências públicas, debates e apresentações - permitiu "a possibilidade de apresentação de emendas de iniciativa popular desde que fossem subscritas por no mínimo trinta mil eleitores e fossem patrocinadas por, ao menos, três associações" (Bonduki, 2017, p. 94). Deste espaço surgiu, então, o Movimento Nacional pela Reforma Urbana, formado por 63 entidades $^{23}$ com opiniões diversas (Bonduki, 2017, p. 98) para entregar ao congresso a chamada Emenda de Iniciativa Popular pela Reforma Urbana. Emenda que sintetizou décadas de discussões e crescentes mobilizações em torno da terra urbana e incluiu muitos dos instrumentos de controle fundiário que posteriormente apareceriam no Estatuto da Cidade.

Das negociações travadas com o Congresso, majoritariamente conservador, sobre o tema resultaram, entre outros, os artigos 182 e 183, aprovados na Constituição de 1989. Artigos que se por um lado delegaram a política de desenvolvimento urbano à aprovação de uma lei específica, por outro representaram um avanço por instituir a função social da propriedade, associada ao atendimento das exigências de um Plano Diretor aprovado pelas câmaras municipais. Instituiu-se, portanto, que a maioria das

23. Desde movimentos de moradia e de entidades profissionais, até segmentos do empresariado e do poder público. 
contribuições deveria passar por um outro processo de regulamentação, cujo primeiro projeto foi apresentado logo em 1989 (PL n. 181/1989), então apelidado "Estatuto da Cidade". Projeto que caminhou até ser aprovado em 2001 por um processo moroso e obstaculizado por setores conservadores e representantes de parte do setor empresarial (Bonduki, 2017, pp. 123-131). Em suma, foi na Constituição que se associou pela primeira vez em âmbito Federal a função social da propriedade ao Plano Diretor, o que o fortaleceu e deu sentido a ambos. Porém foi, também por meio desta, delegada às municipalidades a disputa pela definição daquilo que se enquadra dentro da função social da propriedade, caso a caso, o que quer dizer que a "luta pela reforma urbana passou a ser travada, de maneira descentralizada, em cada município" (Bonduki; Rosella, 2017, p. 181).

O instituto da função social da propriedade é, portanto, estruturante dos objetivos mais amplos e abstratos do Plano Diretor, conquista de uma longa história de demandas sociais associadas ao combate da especulação imobiliária. A sua aplicação está associada no Estatuto da Cidade (2001) ao Parcelamento, Edificação ou Utilização Compulsórios (PEUC), que por meio da notificação de imóveis que não cumprem as condições de ocupação determinadas no Plano podem ser notificados, multados e posteriormente desapropriados. Porém, a sua definição caso a caso perturba seus nobres fundamentos. No caso de São Paulo, podemos obter uma imagem dos imóveis que não cumprem essa função visualizando o mapa na página seguinte (mapa 2.1.1) que mostra os imóveis notificados pelo descumprimento à função social da propriedade. Constatamos que a maioria absoluta destas notificação está localizada dentro da Rede de Estruturação da Transformação Urbana, mais especificamente em entre a região central e o Rio Tietê, região na qual se deseja atualmente canalizar parte do desenvolvimento urbano da cidade.

A sua territorialização associa espaços de crescente atividade imobiliária, colocando em disputa seu caráter social. Podemos questionar em que medida esse instrumento permite ampliar o acesso à terra aos mais pobres e em que medida a ferramenta é usada para disponibilizar terras para o mercado que por motivos 


\section{Mapa 2.1.1}

Territorialização das notificações do não cumprimento da Função Social da Propriedade Geosampa, 2020.

- Imóvel notificado

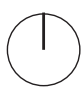

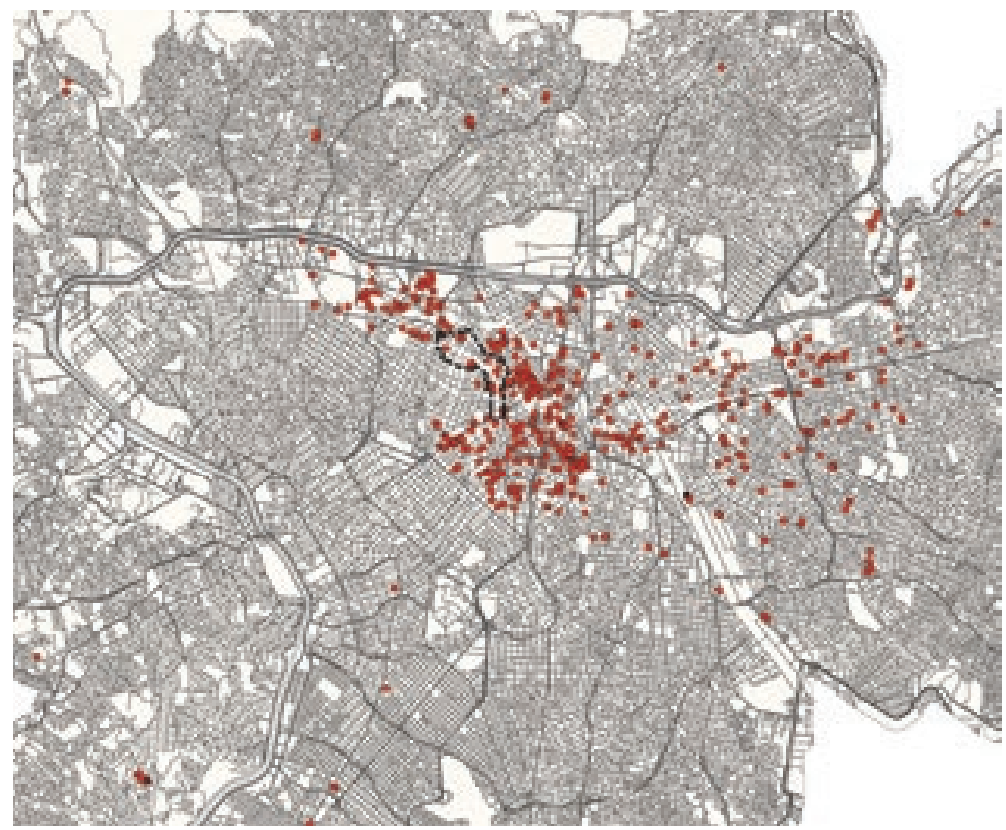

variados, entre eles a própria retenção especulativa, encontram-se imobilizadas. Conforme aponta Rufino (2018):
A função social da propriedade, que num plano difuso se coloca como potencialidade para reprimir a retenção especu- lativa da terra e ampliar seu acesso aos mais pobres, ao mesmo tempo, impulsiona o movimento para que a propriedade exerça uma função econômica. (Rufino, 2018, pp. 97-98)

Conforme aponta Bonduki (2017), entre a Constituição (1989) e a aprovação do Estatuto da Cidade (2001), que regulamentou "o uso da propriedade urbana em prol do bem coletivo, da segurança e do bem-estar dos cidadãos, bem como do equilíbrio ambiental" (Brasil, 2001), surgiram no Brasil uma série de Planos Diretores ou iniciativas de gestões municipais que buscaram aplicar instrumentos discutidos desde o Seminário de Habitação e Reforma Urbana (1963) em um momento prévio à sua regulamentação federal. Neste contexto, cabe mencionar novamente a gestão da prefeita Luiza Erundina (1989-1992), "que se destacou como um laboratório de experiências alternativas, colocando em prática e qualificando o ideário da reforma urbana" (Bonduki, 2017, p. 
113). Em 1991 a prefeitura tentou então, aprovar um plano diretor municipal, mas teve sua iniciativa frustrada na câmara municipal, onde o projeto nem chegou a ser apresentado, dada a forte oposição do setor imobiliário (Bonduki, 2017, p. 119).

A gestão Luiza Erundina foi pioneira na estruturação de uma série de institutos da política urbana que se prolongam até os dias de hoje, instituindo mecanismos de desentralização administrativa via subprefeituras e participação da sociedade civil via conselhos e testando alguns instrumentos urbanísticos esboçados nas discussões pela reforma urbana. Entre estes aprovou a Operação Urbana Anhangabaú, que apesar de judicializada pelo Ministério Público dada a falta de regulamentação, chegou a captar recursos e deu um passo no sentido de construir o conceito de solo criado acessível por meio da "cessão onerosa do espaço público aéreo ou subterrâneo" (Cidade de São Paulo, 1991b). Reforçamos que esse conceito é vital no Planos Diretores do século XXI não só por orientar o desenvolvimento urbano, ao incentivar ou coibir o adensamento em certas regiões, mas também por se constituir como um importante instrumento de arrecadação para a realização de obras públicas. A cessão onerosa do espaço público seria viável neste momento graças a uma instituição criada em um momento anterior à Operação Urbana: a separação do direito de propriedade do direito de construção introduzida na constituição de 1989.

O Estatuto da Cidade (Lei n. 10.257/2001) foi aprovado apenas em 2001 e regulamentou a maioria dos instrumentos que depois viriam a ser incorporados nos Planos Diretores da cidade de São Paulo (PDE de 2002 e na sua versão revisada de 2014). Cabe ainda reforçar aqui a ênfase dada nesta lei federal à "gestão democrática da cidade" incluindo na lei a necessidade de incorporar instrumentos como órgãos colegiados, audiências e consultas públicas, gestão orçamentária participativa, e a "obrigatória e significativa participação da população e de associações representativas dos vários segmentos da comunidade, de modo a garantir o controle direto de suas atividades e o pleno exercício da cidadania" (Brasil, 2001). Questões estas que na gestão pública da cidade de São Paulo seriam fortemente exploradas pelas administrações ditas progressistas. Nesse sentido 
e em contraste com os planos do século XX, Rolnik escreve sobre o Estatuto da Cidade e os planos que dele derivaram:
O Estatuto da Cidade não só estabelece uma nova ordem urbanística, como também define que os principais nortea- dores dessa nova ordem estejam relacionados com aqueles defendidos pelo Movimento Nacional da Reforma Urbana. (...) O Plano Diretor deixa de ter uma concepção tecnocrática baseada na ideia de um modelo ideal de cidade e passa a ser pensado como uma espécie de pacto entre setores da sociedade e cidadão. (Rolnik, 2003 apud Bonduki, 2017, p. 133).

No sentido da regulamentação da cessão onerosa do espaço público, o Estatuto regulamentou a Outorga Onerosa do Direito de Construir (OODC) no seu artigo 28, como vemos abaixo. Verificamos ainda aqui a aproximação entre infraestrutura existente e densidades desejáveis:
Art. 28. O Plano Diretor poderá fixar áreas nas quais o direito de construir poderá ser exercido acima do coeficiente de aproveitamento básico adotado, mediante contrapartida a ser prestada pelo beneficiário.
$\$ 1$ o Para os efeitos desta Lei, coeficiente de aproveitamento é a relação entre a área edificável e a área do terreno.
$\$ 2$ o O Plano Diretor poderá fixar coeficiente de aproveitamen- to básico único para toda a zona urbana ou diferenciado para áreas específicas dentro da zona urbana.
$\$ 30$ O Plano Diretor definirá os limites máximos a serem atingidos pelos coeficientes de aproveitamento, considerando a proporcionalidade entre a infraestrutura existente e o aumento de densidade esperado em cada área (Brasil, 2001, art. 28).

Antes de dar andamento, devemos destacar duas questões importantes para este trabalho, a primeira é a ideia de que tanto o Estatuto da Cidade quanto os Planos Diretores dele derivados partem do entendimento e se constituem como um compromisso com o desenvolvimento urbano associado ao desenvolvimento do sistema de produção capitalista. Não só por criar regras para regular a ação do mercado, mas também dela financiar os 
investimentos públicos, através do pagamento de contrapartidas pela compra de potencial construtivo. Em outras palavras, eles se constituem como via de organização das formas mercantis de produção do espaço e, conforme aponta Rufino (2018), no crédito do "avanço das relações capitalistas como resolução dos problemas urbanos" (Rufino, 2018, p. 86). Ao vincular receitas provenientes da OODC à constituição do Fundo de Desenvolvimento Urbano (FUNDURB) cria-se uma dependência dos planos do século XXI à produção imobiliária continuada e desejavelmente ampliada, especificamente àquela que excede o Coeficiente de Aproveitamento Básico.

Em outras palavras, constata-se que "na metrópole do século XXI, o Planejamento Urbano torna-se cada vez mais refém de um crescimento contínuo da produção imobiliária e de sua valorização, potencializados em tempos de dominância financeira" (Rufino, 2018, p. 86). Nesse sentido, eles se constituem enquanto ideologia de crescimento: "os interesses pró-crescimento geralmente envolvem tanto os segmentos monopolistas e altamente concentrados da classe capitalista quanto o governo local, pois ambos necessitam do crescimento para sobreviver" (Gottdiener, 2016, p. 223). Este pacto entre poder público e os segmentos monopolistas constitui o que Gottdiener chama de "redes ou coalizões de crescimento", cujos interesses "usam os conceitos de desenvolvimentismo e o mito do crescimento para legitimar suas atividades"(Gottdiener, 2016, p. 221). Especificamente sobre a evolução destes planos de encontro com os interesses monopolistas, Rufino (2018) afirma:

\footnotetext{
Embora a renovação do Planejamento Urbano a partir dos anos 1980 parta da crítica do caráter elitista do Zoneamento e da necessidade de maior atenção do Estado às áreas precárias, a crença na expansão do mercado como estratégia de resolução dos problemas permanece subjacente. (Rufino, 2018, p. 97)
}

A segunda importante constatação à qual Rolnik faz citação, e que deriva da anterior, é a ideia de plano na qualidade de pacto, resultado de um processo mais ou menos amplo de negociação entre representadas nas câmaras municipais. Se por um lado esta 
última questão diferencia radicalmente o planos do século XXI daqueles do século $\mathrm{XX}$, ao incoporar os cidadãos na esfera do planejamento urbano, por outro torna esta esfera um contínuo espaço de debate: negociação morosa e suscetível à judicialização por aqueles que têm capacidade de organização ou recursos para tal e que sentem que seus direitos não estão sendo atendidos. A necessidade de construção de consensos para pactuar o desenvolvimento da cidade emerge então desta dificuldade e os instrumentos utilizados para esta tarefa não cabem numa dimensão imaginável.

Especificamente sobre os Planos Diretores, conforme aponta Bonduki e Rosella (2017) devemos reforçar que existe uma continuidade entre o PDE de 2002 (Lei n. 13.430/02) e o de 2014 (Lei n. 16.050/14), sendo o segundo uma revisão do primeiro. Eles diferem, principalmente, pela clareza com que alguns objetivos são colocados e pelo aprimoramento e regulamentação dos instrumentos - alguns deles passaram a ser autoaplicados na promulgação do Plano Diretor de 2014, se esquivando do processo da elaboração de uma lei específica para sua regulamentação.

Iniciamos essa discussão pelo aspecto territorial destes Planos que interessa a este trabalho: a macroárea no qual o Minhocão se insere. Para efeito de comparação, trazemos os mapas que ilustram as macroáreas nos PDE de 2002 (fig. 2.1.1) e 2014 (fig. 2.2.2): de forma geral, podemos observar grande semelhança nesses termos - lembrando que ambos Planos foram elaborados por gestões petistas. A macroárea no qual o Minhocão se insere é Macroárea de Estruturação Metropolitana (MEM), associada de forma mais ampla às várzeas dos rios Tietê, Pinheiros e Tamanduateí, que delimitam o chamado "centro expandido". Regiões conhecidas pela "presença de infraestruturas de grande capacidade (transporte rodo e ferroviário, energia, do sistema hídrico, etc.) e pela presença de terras públicas derivadas do processo histórico de implementação dessas infraestruturas" (D’Almeida, 2019, p. 4) , além de uma estrutura fundiária marcada por grandes lotes, herdada da época industrial. 

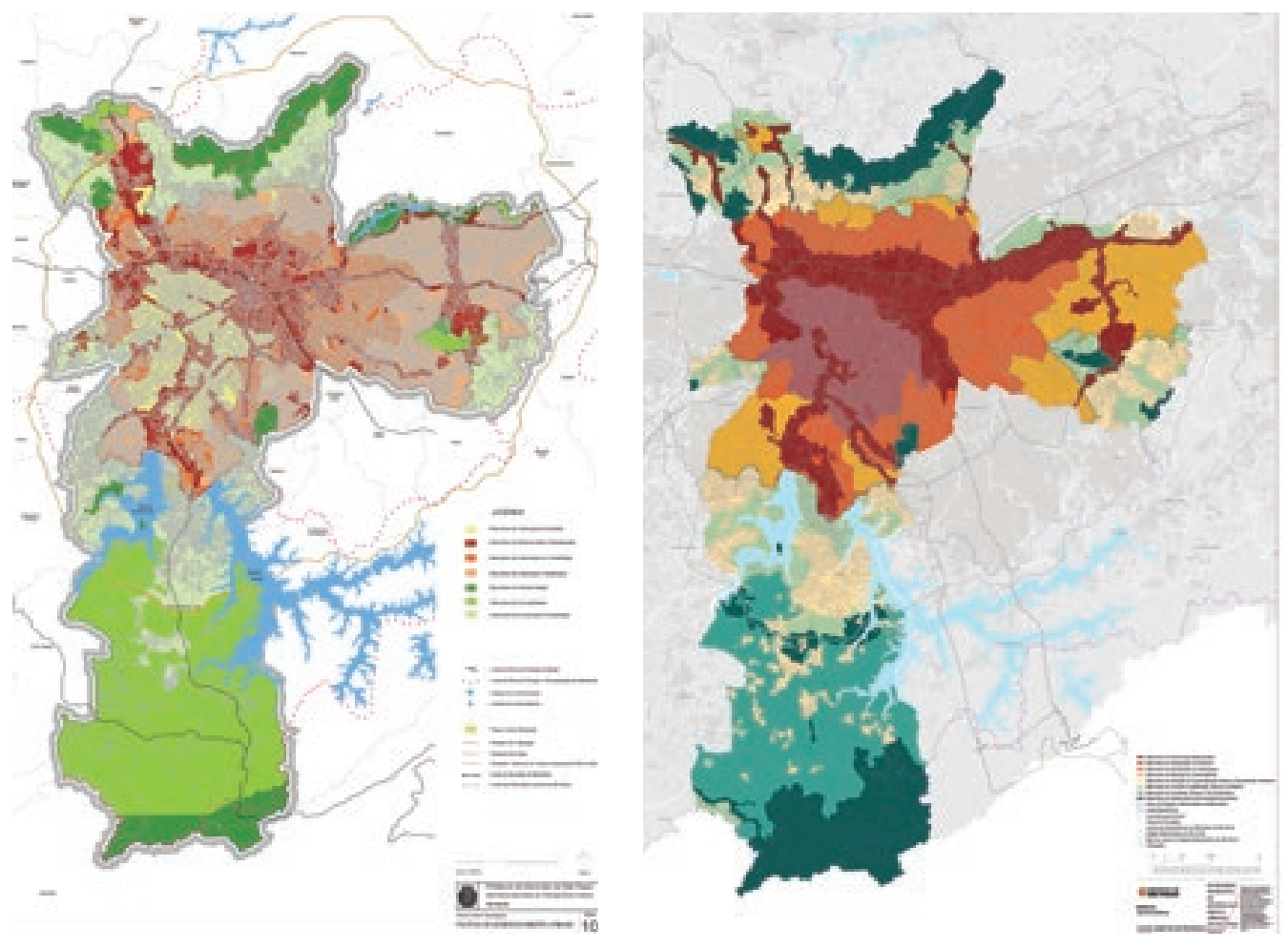

Nestas Macroáreas, em ambos Planos, concentram-se os declarados esforços para canalizar o desenvolvimento da cidade, na busca por "obter melhor aproveitamento das privilegiadas condições locacionais e de acessibilidade” (São Paulo, 2002). Na MEM, o PDE prevê a aplicação de uma série de instrumentos para a transformação urbana: Operações Urbanas Consorciadas (OUC), Áreas de Intervenção Urbana (AIU), Áreas de Estruturação Local (AEL) e concessões urbanísticas. Aqui, portanto, está localizada a totalidade das Operações Urbanas ${ }^{24}$, aprovadas ou não, locais que concentraram ao longo da década de 2000 grande parte da atividade imobiliária. A incorporação da região central na MEM, apta para receber a transformação urbana, parece destoar do resto aqui englobado na medida em que se trata de uma área de "ocupação consolidada" já densamente construída: ela parece se justificar na medida que a Ope-
Fig. 2.1.1

Macroárea de Estruturação Metropolitana (MEM) do Plano Diretor de São Paulo, 2002. Cidade de São Paulo, Lei $\mathrm{n}$. 13.430/02.

\section{Fig. 2.1.2}

Macroárea de Estruturação Metropolitana (MEM) do Plano Diretor de São Paulo, 2014. Cidade de São Paulo, Lei $n$. $16.050 / 14$.

24. Instrumento que se desenvolveu a partir das Operações Interligadas, com base na compra de Certificados de Potencial Adicional de Construção (CEPACs) para financiar investimentos públicos na própria região. 
ração Urbana Centro (1997) foi promulgada antes da definição das macroáreas. Aqui devemos destacar a inclusão da região do entorno do Minhocão.

A potência da atividade imobiliária em determinadas Operações Urbanas da MEM pode ser compreendida pela arrecadação que realizaram por meio da venda de potencial construtivo ${ }^{25}$ em contraste com a arrecadação realizada por meio da OODC. Conforme apontam Rufino (2018) e Nobre (2016), se entre 2004 e 2014 o valor arrecadado de OODC chegou a 1,7 bilhões de reais, as operações urbanas consorciadas somaram, entre 1997 e 2016, 6,3 bilhões de reais (3,7 vezes mais). Desses 6,3 bilhões, $89 \%$ se concentraram na Operação Urbanas Consorciadas Água Espraiada (2001) e Faria Lima (2004), localizadas no vetor sudoeste. O gráfico (gráf. 2.1.1) nos mostra a relação entre a arrecadação nas Operações Urbanas ${ }^{26}$ (vermelho escuro) e no resto da cidade $^{27}$ (vermelho claro). Apesar da relação entre valor arrecadado e metro quadrado construído resultante da compra deste potencial adicional não ser direta, variando por localização na qual foram consumidos, o gráfico atesta a força aqui do mercado com relação ao resto da cidade. A arrecadação nas operações urbanas ao longo de todo o período estudado (2004-2019) representa aproximadamente $170 \%$ sobre o arrecadado no resto da cidade por meio da OODC. Se levarmos em consideração que as Operações Urbanas ocupam apenas um pequena parcela do território, e que a arrecadação é reinvestida apenas nos territórios onde foi captada, a relação entre ambas torna-se ainda mais discrepante. Nesse sentido revelamos uma outra faceta de como o mercado, organizado pelo planejamento urbano, exacerba, em termos de investimentos as desigualdades territoriais.

Do ponto de vista da distribuição dos coeficientes de aproveitamento, Bonduki e Rosella (2017) apontam que o plano de 2002, apesar de representar um importante avanço no senti-

25. No caso das operações urbanas realizada pela venda via leilão público de Certificado de Potencial Adicional de Construção (CEPAC).

26. Por meio de CEPAC e OODC.

27. Por meio de OODC. 


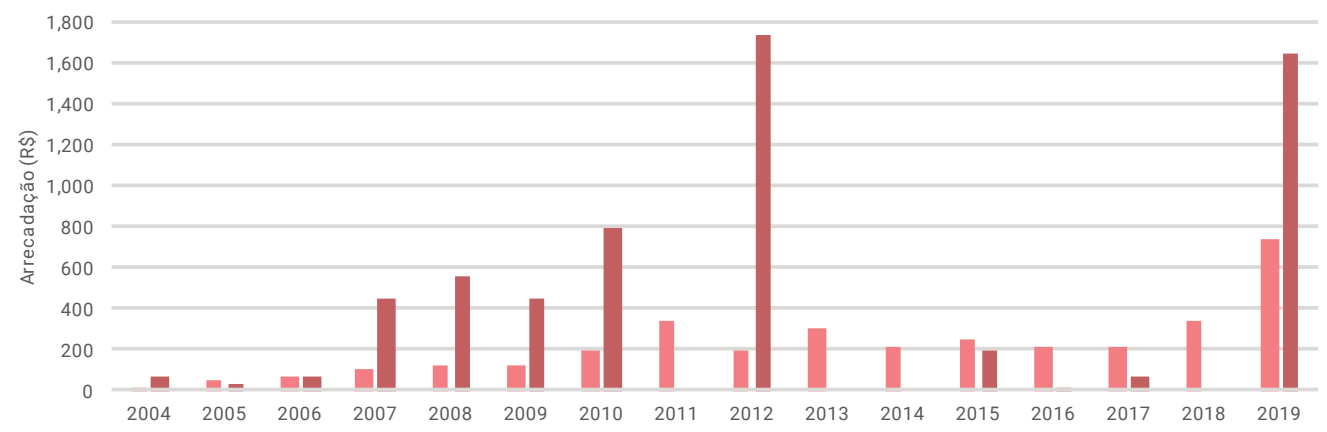

do da incorporação dos instrumentos previstos no Estatuto da Cidade, "guardou muito do modelo definido pela Lei de Zoneamento de 1972" (Bonduki; Rossella, 2017, p. 233). Dada a negociação e forte resistência dos setores relacionados ao mercado imobiliário, principalmente à cobrança de Outorga Onerosa do Direito de Construção, as zonas de adensamento acabaram emulando as antigas zonas nas quais já era possível se adensar mais.

A proposta que garantiu o acordo estabeleceu uma redução gradual do Coeficiente de Aproveitamento Básico (CAB), que passou a ser 1 ou 2, conforme as zonas de uso onde o terreno estava situado. Assim, as antigas zonas, onde o coeficiente de aproveitamento máximo era 4 (Z3, Z4, Z10 e Z12), passaram a ter um $\mathrm{CAB}$ igual a 2 , estabelecendo-se um dispositivo de transição, com a queda gradativa do índice durante dois anos, garantindo um processo mais suave de acomodação dos empreendedores à nova regra.

Nas demais zonas, o CAB passou a ser 1 , mas se acordou que nas antigas Z2, que eram a zona predominante na cidade, haveria uma regra de transição que permitiria aos promotores utilizar o coeficiente igual a 2 , sem o pagamento de outorga onerosa, em edifícios residenciais que reduzissem a taxa de ocupação a 25\% (a chamada fórmula de Adiron) (Bonduki; Rossella, 2017, p. 200).
Gráf. 2.1.1

Arrecadação anual via OODC e CEPAC, nas Operações Urbanas e no restante da cidade. "Sistema de Orçamento e Finanças (SOF). Secretaria Municipal da Fazenda. Prefeitura do Município de São Paulo Diretoria de Gestão das Operações Urbanas. SP Urbanismo. Prefeitura do Município de São Paulo".

Arrecadação Operações Urbanas

Arrecadação resto da cidade

Foi apenas em 2014 que o Plano conseguiu finalmente revogar a 
fórmula de Adiron acima citada, que se perpetuou ao longo de quatro décadas, e instituir logo na aprovação da lei o Coeficiente de Aproveitamento Básico 1 para toda a cidade, pauta já bastante difundida dentro dos movimentos da reforma urbana, mas que sua aplicação tinha sido postergada nas negociações do PDE de 2002.

Este último plano foi, portanto, mais enfático no que tange aos mecanismos para atingir seus objetivos: apesar de já existir no PDE de 2002 a vontade escrita de ordenar os "usos e intensidades de ocupação do solo de forma equilibrada em relação à infraestrutura disponível, aos transportes e ao meio ambiente, de modo a evitar ociosidade e sobrecarga dos investimentos coletivos"(Cidade de São Paulo, 2002). É apenas no PDE de 2014 que ela se manifesta claramente no território ao associar as áreas de adensamento ao transporte coletivo (em torno das estações de metrô e trem e ao longo de eixos de transporte coletivo) por meio da constituição dos Eixos de Estruturação da Transformação Urbana ${ }^{28}$, novidade incorporada neste Plano. Este último Plano, portanto, é mais efetivo no sentido de atingir o objetivo geral de "conter o processo de expansão horizontal da aglomeração urbana” (Cidade de São Paulo, 2014). Junto à MEM estes Eixos definem o que se chama de Rede de Estruturação da Transformação Urbana, que é a mais próxima territorialização deste objetivo.

Podemos identificar, ainda neste segundo Plano, a ampliação de uma agenda relacionada ao desenvolvimento sustentável: a palavra sustentável e suas correlatas aparecem 22 vezes na versão de 2002 e 117 na versão de 2014. Apesar dessa contagem não dizer muito sobre a efetividade do plano no enfrentamento do tema, podemos dizer que ele foi vestido por esta nova pauta, que foi ganhando força nas políticas de desenvolvimento urbano

28. "Os eixos de estruturação da transformação urbana são porções do território onde é necessário um processo de transformação do uso do solo, com o adensamento populacional e construtivo articulado a uma qualificação urbanística dos espaços públicos, mudança dos padrões construtivos e ampliação da oferta de serviços e equipamentos públicos" (São Paulo, 2014). 
mundiais principalmente a partir da década de $1990^{29}$.

No bojo destas discussões que relacionam a sustentabilidade ao desenvolvimento urbano surge também a ideia da "cidade compacta" associada ao conceito de Desenvolvimento Orientado para o Transporte Sustentável (DOTS) ${ }^{30}$. O DOTS, fortemente difundido por entidades norte-americanas com braços no Brasil ligadas à mobilidade e ao desenho do espaço público ${ }^{31}$, associa o desenvolvimento urbano à ideia de cidade compacta por meio do desenvolvimento orientado pela rede de transporte coletivo. Associação inexistente nos primeiros documentos internacionalmente consagrados que visam ao "desenvolvimento sustentável", como a agenda 21 ou a agenda $2030^{32}$. Conforme aponta o "Guia de Implementação de Políticas e Projetos de DOTS" do ITDP, o PDE 2014 deu importantes passos no avanço desta proposta,
O Plano Diretor Estratégico do Município de São Paulo-SP1 (Lei Municipal no 16.050, de 31 de julho de 2014), premiado em 2016 pela ONU-Habitat como exemplo de boas práticas no planejamento urbano, evidencia a importância da integra- ção de estratégias setoriais no ordenamento territorial para uma política urbana que contribua com a promoção de uma mobilidade mais sustentável. Das dez principais estratégias de desenvolvimento estabelecidas pelo plano, sete têm relação direta com os princípios de DOTS. (ITDP, 2017)

Os Eixos de Estruturação da Transformação Urbana são portanto peças fundamentais nessa vontade de unir desenvolvimento urbano ao transporte coletivo. São neles determinados os

\footnotetext{
29. Podemos citar aqui a Conferência das Nações Unidas sobre o Meio Ambiente e o Desenvolvimento, conhecida como Eco-92 ou Rio-92, realizada na cidade do Rio de Janeiro, que pactuou os objetivos para o desenvolvimento do século XXI entre os chefes de estado presentes e resultou na chamada "agenda 21".

30. Em inglês Transit-oriented Development (TOD).

31. Estamos falando das instituições Institute for Transportation and Development Policy (ITDP), fundada em 1985, United State Environmental Protection Agency (EPA), fundada em 1970 e World Resources Institute (WRI), fundada em 1982.
}

32. Por outro lado, a ideia de cidade compacta e os DOTS aparecem em publicações da ONU em 2013. Ver UN-Habitat, 2013. 
Fig. 2.1.3

Ilustração das Diretrizes para o Ordenamento da Paisagem no PDE de 2014. Cidade de São Paulo, Lei n. 16.050/14.

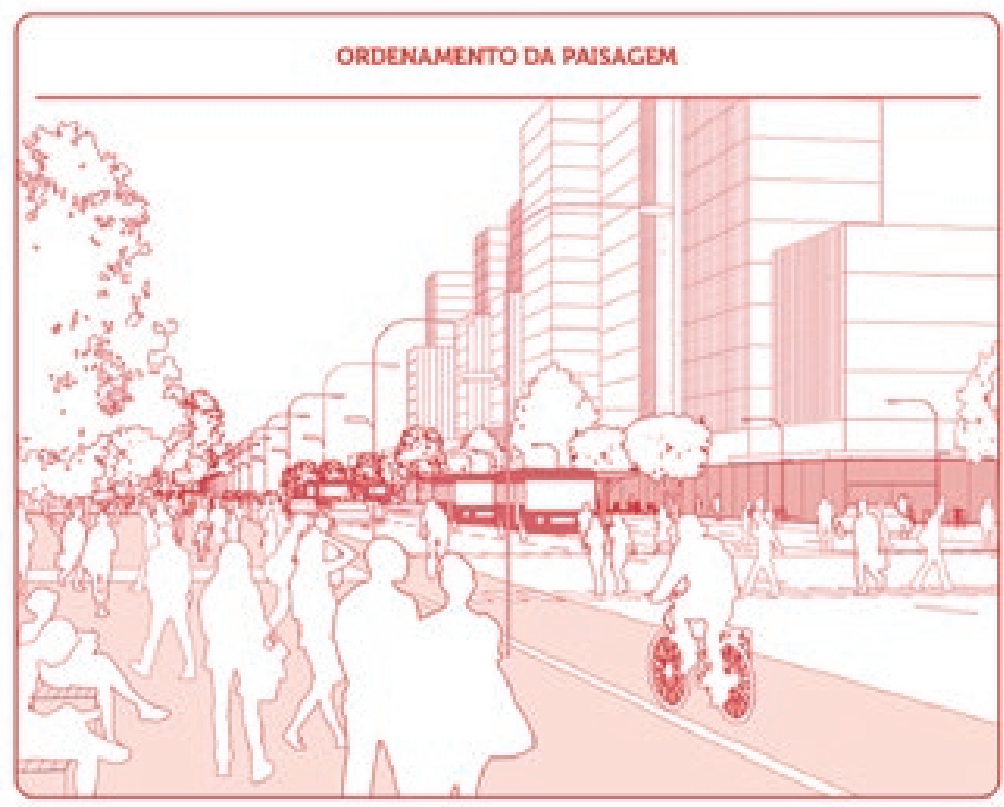

maiores coeficientes de aproveitamento $(\mathrm{CA}=4)$, incentivados por meio da fachada ativa (uso misto no térreo) e desobrigando a construção de vagas de estacionamento, consequentemente desonerando o empreendedor imobiliário de uma grande área destinada às garagens dos edifícios. Na imagem (fig. 2.1.3) verificamos uma simulação do que se espera desses espaços, edifícios altos, térreo comercial, transporte coletivo no meio da avenida, ciclovia e parque ao lado. Como veremos no capítulo 3, esta última novidade do Plano Diretor - que desde 1972 obrigava aos empreendimentos a incorporação de um número mínimo de vagas, produto de uma política urbana voltada para o incentivo ao uso de automóveis - pode ter incentivado a construção de novos empreendimentos em terrenos exíguos, como aqueles localizados nas áreas centrais.

No sentido de desincentivar o uso do automóvel, a gestão de Fernando Haddad (2013-2016) implementou um programa de "ativação dos espaços públicos" via "colocação do pedestre, do transporte público e das bicicletas como protagonistas em detrimento do automóvel” (Kwak, 2018, p. 17). Alguns elementos-chave formam parte deste programa: (1) a implantação de uma extensa malha cicloviária, até então praticamente inexisten- 
te na cidade de São Paulo; (2) os programas Ruas Abertas, que propunham abrir para o pedestre o viário de uma rua de cada subprefeitura aos domingos, e Paulista Aberta, que passou a fechar a emblemática Av. Paulista todos os domingos e feriados; (3) o programa Centro Aberto, que contou com a consultoria do arquiteto Jan Gehl, e a regulamentação dos chamados Parklets ${ }^{33}$, ambos buscando requalificar o espaço da calçada; (4) o "resgate de ativos públicos" reabrindo ao público o Clube Tietê (Zona Norte) e o Parque do Jockey ${ }^{34}$. Estas ideias - de qualificar e ampliar a oferta de espaços de lazer público, em alguns casos, diminuindo o espaço para o automóvel - contribuíram para que no campo progressista a gestão Haddad fosse elogiada pela construção de uma "cidade mais inclusiva e democrática" (Kwak, 2018, p. 12).

A raiz desta pluralidade de projetos e programas que foram implantados na gestão Haddad — somados à própria revisão do Plano Diretor, do Zoneamento e da realização dos Planos Regionais, todos eles acompanhados das suas respectivas audiências públicas - a cidade de São Paulo se transformou num intenso palco de debates entre múltiplos agentes, alavancando pautas urbanas antes pouco públicas. Conforme aponta Kwak:
(...) a sociedade civil organizada mostrou intensa mobilização neste quadriênio. Com as mudanças em ritmo acelerado em di- versas áreas, as políticas públicas entraram no debate cotidiano da população. Isso foi um aspecto bastante relevante, propi- ciando maior dinamismo e engajamento social de diversos grupos sociais, ampliando o nível de deliberação democrática. Desde as inúmeras consultas e audiências públicas nas revisões do marco regulatório urbanístico como o Plano Diretor Estra- tégico (PDE) e o Zoneamento, até as implantações das ciclovias e discussões do Plano de Mobilidade (PlanMob) (São Paulo, 2016), passando pelo acalorado debate da Paulista Aberta e

\footnotetext{
33. Pequenas praças construídas, tanto pelo poder público quanto pelo poder privado, no espaço destinado para estacionamento dos automóveis, no leito carroçável das vias.

34. Recebido em troca de uma dívida do Jockey Clube de São Paulo com a prefeitura (Kwak, 2018, p. 19).
} 
do confronto dos aplicativos de mobilidade individual versus taxistas, a cidade teve um período efervescente de mobilização, ora apoiando as medidas, ora sendo radicalmente contra, num contexto de quase polarização e antagonismo (Kwak, 2018, p. 26).

Devemos destacar aqui duas referências internacionais importantes na divulgação deste novo modelo de cidade, bem recebidas nas faculdades de arquitetura do país e por entidades associadas à mobilidade ativa. A primeira é o consagrado arquiteto dinamarquês Jan Gehl, seguidor de Jane Jacobs, escritor do livro Cidade para pessoas (Gehl, 2015.) e forte militante do desenho de espaços públicos voltado para o pedestre em contraposição daquele voltado para o automóvel. Conforme mencionado, durante a gestão Haddad, ele prestou consultoria no projeto Centro $\mathrm{Aberto}^{35}$ e realizou workshop com técnicos da prefeitura, que resultaram em um novo projeto para o Vale do Anhangabaú, pautado na requalificação das calçadas, ativação do térreo dos edifícios e na implantação de um grande chafariz no centro da praça.

A segunda referência é o ex-prefeito de Nova Iorque Michael Bloomberg (2002-2013), associado à secretária do Departamento de Transportes da Cidade de Nova Iorque, Janette Sadik-Khan (2007-2013), escritora do livro Streetfight: Handbook for an Urban Revolution; juntos. implementaram um programa de redesenho de ruas da cidade, visando o aumento do nível de segurança viária, aumentando o espaço para o pedestre em detrimento daquele do automóvel. A gestão deles foi marcada pela implantação de projetos de baixo custo e alto impacto midiático, como a transformação da emblemática Times Square em um espaço de descanso - com grama sintética e cadeiras de praia - aumento radical da malha cicloviária, usando na maior parte apenas tinta no piso para demarcar a mudança de uso na via, e implantação programas tipo Summer Streets - que abriam ruas para usos recreativos, fechando-as para o automóvel. Na gestão Haddad, a

35. Cidade de São Paulo. Espaços no centro da cidade ganham intervenções urbanas temporárias. 26 de setembro de 2014. 


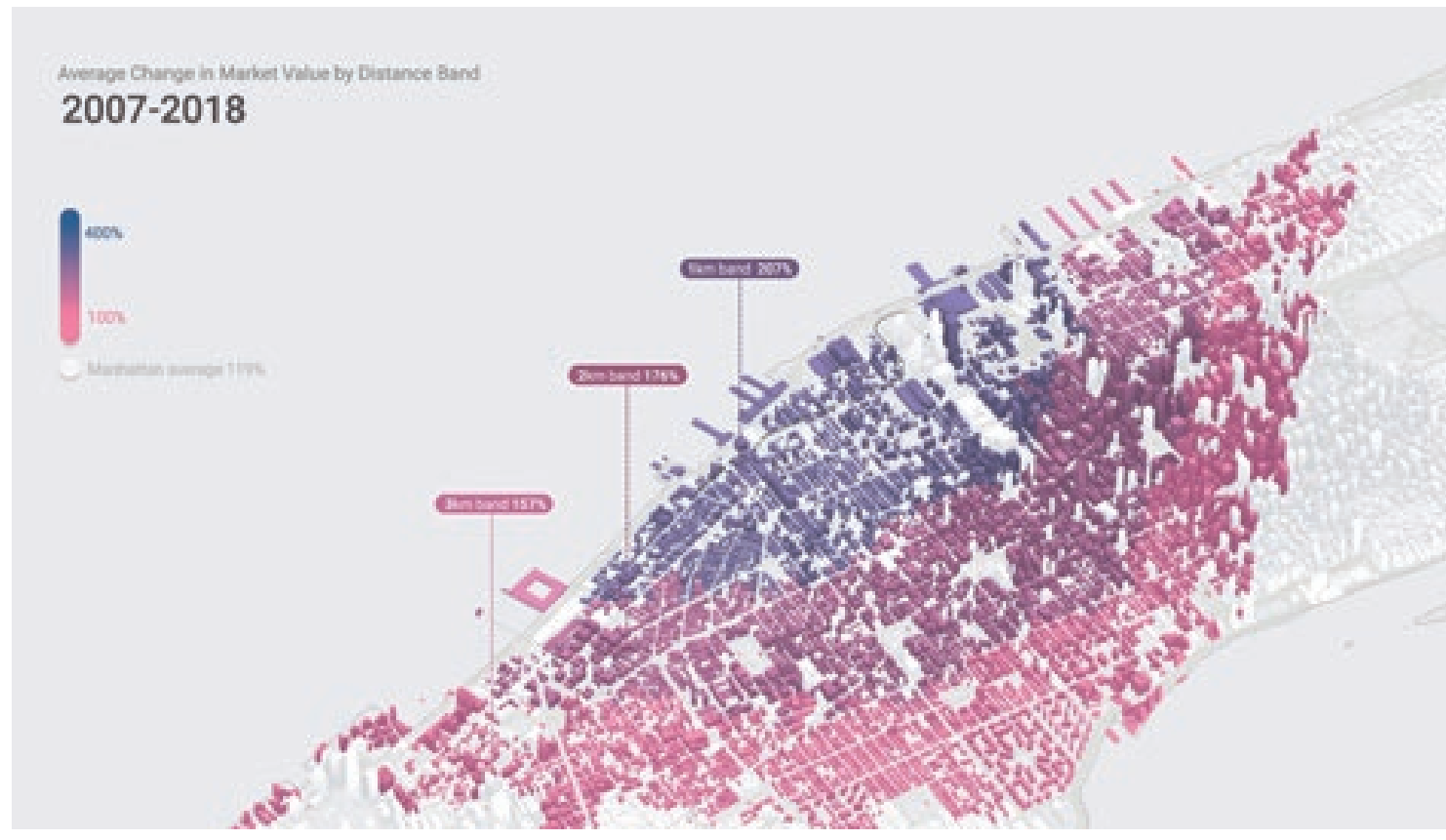

prefeitura passou a integrar a Iniciativa para a Segurança Viária da Bloomberg Philanthropies, ${ }^{36}$, organização que conta com a colaboração de Janette Sadik-Khan. Em 2016, a mesma gestão ganhou prêmio de US\$ 5 milhões da mesma instituição pelo projeto Ligue Pontos, que busca fortalecer a cadeia produtiva dos pequenos agricultores localizado na zona rural da cidade de São Paulo como forma de resistir à expansão urbana.

Devemos destacar ainda sobre a gestão Michael Bloomberg a inauguração do parque High Line em Nova Iorque, referência recorrente daqueles que visam a transformação do Minhocão em tal. O parque em questão foi Implantado sobre uma antiga via férrea elevada que servia antigamente de apoio às atividades industriais da cidade, $c 0 m 2.2 \mathrm{~km}$ de extensão atravessando o bairro industrial Chelsea. Conforme aponta o relatório da Prefeitura de São Paulo intitulado "Parque Minhocão", que discutiremos adiante, "a construção do Parque (Highline) é resultado de um intenso trabalho da sociedade civil e esferas públicas,
Fig. 2.1.4

Aumento de preços dos imóveis no entorno do High Line de Nova York. Dark Matter Laboratories, 2019.

36. Entidade sem fins lucrativos fundada pelo magnata ex-prefeito de Nova Iorque Michael Bloomberg. 
envolvendo a doação da área ao município, concurso de projetos e alterações no zoneamento, entre outros" (Cidade de São Paulo, 2019, p. 136). Além do design arrojado e dos elevados investimentos para sua implantação, que o colocam entre os parque mais custosos do mundo (US\$220 milhões), o High Line é famoso por ter desencadeado um vertiginoso processo de valorização imobiliária. Segundo o próprio relatório da prefeitura "desde seu lançamento, os valores das quadras ao redor da seção 1 do parque cresceram em cerca de 50,6\% e o da seção 2 em cerca de 48,2\%" (São Paulo, 2019, p.140). Em pesquisa publicada em $2019^{37}$ essa valorização se mostra ainda mais dramática (fig. 2.1.4): nas cores mais escuras verificamos as áreas que mais valorizaram na região dos entorno do High Line. Verificamos que, entre 2007 e 2018 estas propriedades se valorizaram em média $207 \%$, valor que aumenta na medida que nos aproximamos do parque, sendo que algumas chegam aos $400 \%$.

Finalmente, outra novidade do PDE de 2014 são os Projetos de Intervenção Urbana (PIUs). Conforme aponta D’Almeida (2019), a gestão pública apresenta esta nova instituição não como um novo instrumento mas como um procedimento "com objetivo de reunir e articular os estudos técnicos necessários a promover o ordenamento e a reestruturação urbana em áreas subutilizadas da cidade e com potencial de transformação"(D’Almeida, 2019, p. 8). Se transformados em leis, eles possibilitam a mudança de parâmetros urbanísticos e coeficientes de aproveitamento ao incorporar, após estudos comprobatórios da sua utilidade pública, instrumentos de estruturação urbana como OUC, AIU e AEL. Diferentemente das Operações Urbanas, o perímetro de novos PIUs podem ser definidos depois de promulgado o PDE (dentro da Rede de Estruturação e Transformação Urbana) e até mesmo podem ser sugeridos por meio de Manifestação de Interesse Privado (MIP). Somado ao fato de que a "definição sobre a característica e finalidade dessa intervenção urbana" é "delegada caso a caso" (D’Almeida, 2019, p. 9), eles se constituem como um procedimento que outorga maior flexibilidade à mudança das leis de uso, ocupação e parcelamento 
do solo. O PIU permite ainda a destinação de terras públicas ou desapropriações para realização certo projeto urbano, se constituindo aqui também como uma ferramenta de disponibilização de terras para o mercado. O conteúdo final dos PIU, segundo decreto que regulamenta a sua aplicação (Decreto n. 56.901/2016), deverá incluir:

I - proposta de ordenamento ou reestruturação urbanística para o perímetro delimitado, com a definição de programa de intervenção, fases de implantação, parâmetros urbanísticos e instrumentos de gestão ambiental necessários;

II - modelagem econômica da intervenção proposta, considerando especialmente os mecanismos de financiamento e fonte de recursos necessários;

III - definição do modelo de gestão democrática de sua implantação, privilegiando o controle social e os instrumentos para monitoramento e avaliação dos impactos da transformação urbanística pretendida sobre o desenvolvimento econômico e social da área objeto de estudo; IV - elementos complementares necessários, nos termos do artigo 136 da Lei no 16.050, de 2014 (Cidade de São Paulo, 2016b).

A partir da promulgação do último PDE (2014), vimos um aumento gradativo na quantidade de PIUs abertos pela SP Urbanismo, empresa pública responsável pela sua coordenação, constituindo-se como um procedimento que gradativamente se generaliza e normaliza (D’Almeida, 2019). Analisando os PIUs em andamento, no sentido que levantamos acima, a autora defende que a sua aplicação tende a priorizar a concessão de espaço urbano:

É neste caso que se desenvolvem os processos mais críticos da relação público-privada instituída por meio do PIU: apesar de sua elaboração ser de responsabilidade do poder público (Cidade de São Paulo, 2014, art.136), o PIU pode ser formulado e proposto pela iniciativa privada interessada na concessão de ativos públicos naquele território, que são identificados na proposta, por meio da parceria com a empresa pública São Paulo Urbanismo. Torna-se assim 
um dispositivo que indica quais imóveis da cidade devem ser desapropriados para a implantação do programa de intervenções e modelagem financeira do projeto urbano de interesse público apresentado pelo interessado privado. (D’Almeida, 2019, p. 9)

Devemos destacar aqui a ponderação de Rufino (2018) sobre essa associação de um instituto do planejamento urbano à ideia de flexibilização, coerente no atual cenário macroeconômico: "a regulação que é inicialmente lida como mecanismo de controle será progressivamente associada à ideia de flexibilização, sempre se moldando e sendo moldada por interesses dominantes" (Rufino, 2018, p. 87).

$\mathrm{Na}$ linha do desencorajamento ao transporte individual e do desenvolvimento urbano associado à rede de transporte coletivo, devemos destacar que no PDE o Minhocão foi objeto de um artigo específico que trata da sua gradual desativação para o tráfego de veículos motorizados. No capítulo que trata das "disposições finais e transitórias" do Plano Diretor de 2014, foi acrescentado no artigo 375, que aprova o enquadramento de determinadas áreas da cidade nas Zonas Especiais de Proteção Ambiental (ZEPAM), o seguinte parágrafo:

Lei específica deverá ser elaborada determinando a gradual restrição ao transporte individual motorizado no Elevado Costa e Silva, definindo prazos até sua completa desativação como via de tráfego, sua demolição ou transformação, parcial ou integral, em parque. (São Paulo, 2014, art. 375).

Conforme vimos, o Elevado se insere dentro da Macroárea de Estruturação Metropolitana (MEM) e no Zoneamento, o seu entorno se enquadra dentro da Zona Eixo de Estruturação da Transformação Metropolitana (ZEM), na qual o coeficiente de aproveitamento máximo é igual a 4 (quatro) e dispensa gabarito máximo de altura. Na lei específica promulgada em 2018 (Lei n. $16.833 / 2018$ ) a sua transformação foi delegada à realização de um PIU, atualmente em andamento. Ainda devemos destacar que o Minhocão se insere dentro do PIU Setor Central, atualmente em discussão, que veremos mais adiante. 


\section{A construção dos discursos em torno da transformação do Minhocão: as organizações da sociedade civil e os vereadores}

Dentro do movimento global de desregulamentação das economias nacionais na busca pela captação de capitais que circulam pelo globo e associado à descentralização federativa a partir da constituição de 1988, as escalas local e regional têm ganhado protagonismo como plataforma de embarque e desembarque desses capitais (Brandão, 2012, p. 31), com suposto "poder ilimitado" (Brandão, 2012, p. 38) para o desenvolvimento territorial. Deste processo, Brandão (2012) aponta o surgimento de um "pensamento único localista" que "crê piamente na capacidade das vontades e iniciativas dos atores de uma comunidade empreendedora e solidária, que tem controle sobre seu destino e procura promover a governança virtuosa lugareira" (Brandão, 2012, p. 38).

Neste sentido, organizações da sociedade civil, "comunidades solidárias", "microiniciativas" têm ganhado destaque na disputa pelo desenvolvimento urbano e se valem ou dos espaços institucionalizados de participação pós-estatuto da Cidade ou do poder político para promover as suas vontades. Se por um lado a ação dessas organizações pode ser entendida como uma disputa pelos rumos da cidade no sentido da construção do "melhor" espaço comum, por outro, cabe analisar "processos assimétricos em que um agente privilegiado (os centros de decisão) detém o poder de ditar, (re)desenhar, delimitar e negar domínio de ação e rádio de manobra de outrem"(Brandão, 2012, p. 50).

Analisaremos, então, as três organizações da sociedade civil (Associação Parque Minhocão, Movimento Desmonte Minho- 
cão e São Paulo sem Minhocão), o contexto na qual elas surgem, seu corpo dirigente, que narrativas elas promovem, quais são os principais agentes que veiculam suas ideias e como elas atuam no espaço. Na sequência buscamos articular às mesmas a atuação de vereadores que propuseram projetos de Lei que tratam da transformação desta Estrutura. Sobre os vereadores, analisaremos quatro mandatos (Nabil Bonduki, Police Neto, Caio Miranda e Camilo Cristófaro), verificando como a pauta do Minhocão se associa ao seu programa e à sua plataforma de governo em relação a outros projetos de leis e emendas.

\section{Organizações da Sociedade Civil}

\section{Associação Parque Minhocão}

Fundada no dia 14 de agosto de 2013 e cadastrada como Associação Privada no dia 5 de junho de 2014, a Associação Parque Minhocão foi criada logo no início das discussões envolvidas na revisão do Plano Diretor Estratégico, especificamente um mês após a entrega do projeto de lei do PDE (PL 688/2013) pelo poder executivo à Câmara. A história da organização está intimamente associada à "militância" do seu presidente, o empresário Athos Comolatti. Já em 2005, antes mesmo da existência da associação, após ter conhecimento do projeto para o High Line, Comolatti procurou o então vereador Aurélio Nomura (PV) para criar um parque sobre o Minhocão, inspirado ainda pelo projeto do arquiteto Pitanga de Amparo que ocupou a capa do Jornal da Tarde em 1987. A ideia resultou no Projeto de Lei n. 664/2005, engavetado após tramitar por algumas comissões ${ }^{38}$. Na justificativa do projeto de lei o vereador cita:

A solução proposta, e que irá transformar a área das Avenidas São João e General Olímpio da Silveira em um jardim, surgiu de duas vertentes. A primeira foi o aproveitamento de experiências

38. Comolatti, Athos. Como o Minhocão me transformou em um ativista acidental. Esquina, 22 de dezembro de 2017 (link para site na bibliografia). 
de outras cidades, como Nova York, com o seu High Line, que foi uma inovação arquitetônica, projetando um parque em um elevado que continha linhas férreas, e que corre por 22 quarteirões; e como Paris com seu Promenade Plantée, próximo da Ópera da Bastilha, que é um parque que vai em uma via elevada da Praça da Bastilha até o Bois de Vincennes, com cerca de $5 \mathrm{~km}$. $\mathrm{E}$ a segunda vertente é a possibilidade de se aproveitar o Elevado que se queria demolir. (São Paulo, JPL 664/2005).

A associação busca, como seu nome diz, a construção de um parque elevado sobre o Minhocão ao longo da totalidade de sua extensão e se opõe enfaticamente à ideia de sua demolição (parcial ou total). Entre as justificativas que embasam tal projeto, os organizadores defendem a abertura de espaços públicos para a socialização, pautados por uma carência que se tornou evidente nas mobilizações de junho de 2013 e que "trouxeram para o centro dos debates públicos as mazelas da vida nas cidades, enfeixadas em torno do tema da mobilidade urbana" ${ }^{39}$. Em artigo publicado no portal Vitruvius em fevereiro de 2014, data entre a fundação da associação e sua formalização enquanto figura jurídica, Comolatti, Levy e Von Poser escreveram sobre a necessidade de "refundar a democracia" mobilizando as seguintes referências e vantagens que um projeto como esse poderia trazer:

Muitos outros aspectos convergem para a urgência do assunto. Desde a obra seminal de Jane Jacobs, sabe-se que a cidade é o espaço privilegiado de (re)produção de elementos intangíveis. Uma área de acesso público como o Parque Minhocão favorece uma série de dimensões esquecidas da cidade: os espaços de contemplação da paisagem, os espaços de redescoberta do afeto, através da relação e do encontro com o outro desconhecido (alteridade), os espaços em que o tempo é significado não pelas demandas do exterior, como o mundo do trabalho, mas sim pela perspectiva do flâneur de Walter Benjamin. Tudo isso somado à recuperação urbanística dos bairros hoje degradados pelo Minhocão. 
Esses elementos intangíveis são fundamentais para a vida em sociedade, por reduzir a ênfase no uso do espaço urbano como área de circulação (de preferência, do carro), ênfase essa que prejudica a noção de pertença e de agregação social. ${ }^{40}$

Após a primeira frustração, em fevereiro de 2014, a associação se mobilizou para articular uma nova frente de legisladores para dar seguimento às suas vontades. Temos conhecimento que no evento de fundação da associação estavam presentes os vereadores Police Neto e Nabil Bonduki. Após o recebimento de um abaixo-assinado com 600 assinaturas ${ }^{41}$ a favor da transformação do Elevado em parque, esses vereadores, somados a Toninho Vespoli, Ricardo Young, Antônio Goulart, Gilberto Natalini e Floriano Pesaro, propuseram o Projeto de Lei n. 10/2014, que sugeria a criação do Parque Minhocão e previa sua gradual desativação enquanto via elevada para o tráfego de veículos. Este projeto de lei seria promulgado apenas em fevereiro de 2018, pelo então prefeito João Dória.

Com forte atividade nas mídias, boa representação na Câmara Municipal - principalmente representada pelo vereador Police Neto - e articulação com outras entidades e organizações culturais, a associação além de organizar ativamente uma diversidade de eventos culturais sobre o Elevado, apoiou diversos concursos de projetos e workshops para estudantes e conquistou uma série de capas de revista e matérias de jornal. Ela administra uma conta na rede social online Instagram com mais de 26 mil seguidores e outra no Facebook com mais de 10 mil, continuamente alimentadas com fotos de apropriações diversas do espaço público fechado para o automóvel. Em setembro de 2013 a associação abrigou na sua sede, localizada em apartamento de frente ao Elevado, a parte da exposição da X Bienal de Arquitetura de São Paulo chamada Modos de Negociar, que tratou sobre a história do Highline.

40. Idem.

41. Comolatti, Athos; et al. O Parque Minhocão e a alma da cidade. Vitruvius, maio de 2014 (link para site na bibliografia). 
Em artigo também para o portal Vitruvius, em 2014, o advogado Wilson Levy Braga da Silva Neto ${ }^{42}$, membro da organização, declarou sobre a necessária construção de consensos para viabilizar as transformações na cidade, escrevendo em palavras a forma pela qual a associação busca atingir seus objetivos:
O desafio é reconstruir (...) a teia de relações sociais que permi- ta que essa posição assuma o papel de um fluxo comunicativo que, no debate livre de ideias, produza um consenso em torno do assunto e pressione o Poder Executivo municipal a tomar uma decisão favorável a essa posição. Em resumo, o desafio é abrir uma clareira que estimule a consolidação de uma esfera pública que legitime uma resposta, qualquer que seja (prefe- rencialmente a nossa!). ${ }^{43}$

Destacamos ainda algumas particularidades sobre a composição da diretoria da Associação Parque Minhocão cujos integrantes, como o próprio presidente afirma, na sua maioria não residem no entorno do Elevado. A diretoria é composta por pessoas, na sua maioria, com relativo reconhecimento no universo da arquitetura, do urbanismo e das artes: o empresário Eduardo Marcelo Strumpf, o fotógrafo formado em Direito e morador do entorno Felipe Morozini, o crítico de arquitetura e urbanismo Fernando Castelo Serapião, o arquiteto de projetos de alto padrão Marcio Kogan, o arquiteto e artista plástico Paulo Fernando Von Poser e a ativista da mobilidade ativa e jornalista do canal Bike Legal Tatiana Falzoni Leite. Finalmente, o seu presidente Athos Comolatti é sócio da empresa Samaúma Locação de Imóveis ltda., cujo objeto social é a locação de imóveis próprios que somam um capital declarado de mais de $\mathrm{R} \$ 25$ milhões de reais ${ }^{44}$. O apartamento em que a sede da associação está endereçada foi comprado por Comolatti em novembro de 2012 de frente ao elevado

42. Wilson Levy Braga da Silva Neto foi chefe de gabinete da Secretaria de Estado da Educação de São Paulo (2017-2018), membro efetivo da Comissão de Direito Urbanístico da Ordem dos Advogados do Brasil - Seção de São Paulo (OABSP 2016-2019) e diretor do programa de pós-graduação em Cidades Inteligentes e Sustentáveis na Universidade Nove de Julho desde 2018.

43. Levy, Wilson. Esfera pública, interesse público e o Parque Minhocão.

Vitruvius, fevereiro de 2014 (link para site na bibliografia).

44. Dados obtidos na Junta Comercial do Estado de São Paulo (JUCESP). 
(imediatamente vizinho ao mesmo), objetivando um endereço próximo ao futuro parque, tendo em vista que nenhuma das pessoas que tinham sido mobilizadas na fundação da organização morava no entorno.

\section{Movimento Desmonte Minhocão}

O Movimento Desmonte Minhocão (MDM) foi fundado no dia 15 de agosto de 2015 em resposta ao andamento do projeto do Parque Minhocão dentro do recém-promulgado Plano Diretor Estratégico e está composto por moradores do entorno do Elevado, principalmente moradores dos bairros de Santa Cecília e Higienópolis. Sem figura jurídica formalizada, o movimento exerce pressão dentro da Prefeitura por meio da vinculação de seus diretores com associações de bairro e outras instâncias de participação institucionalizados dentro de órgãos colegiados do poder público. Como seu nome diz, o movimento visa a demolição completa do Elevado; a imagem que representa a entidade em sua página no Facebook é a Praça Marechal Deodoro antes da construção do Minhocão (fig.1.1.4) reivindicando simbolicamente a antiga "cinelândia" paulista ao trazer para o presente a São João da década de 1950. Nos meios de comunicação, o MDM denuncia continuamente problemas relacionados à segurança pública e de incomodidade ambiental relacionadas à poluição e ao ruído gerados pelos automóveis que trafegam sobre e sob a via.

Alguns dos diretores que representam a sociedade civil em espaços de participação são: Artur Monteiro Roçado, membro do conselho participativo da Sé; David Brandão, paisagista, presidente da Associação dos Paisagistas, Agrônomos, Jardineiros, Floristas, Ecologistas e Empresas do Segmento; Dinah Darcy, presidente da Associação de Moradores e Comerciantes de Campos Elísios; Francisco Gomes Machado, presidente do Conselho de Segurança (CONSEG) de Santa Cecília, Higienópolis, Barra Funda e Campos Elíseos; José Geraldo Oliveira, vice-presidente do mesmo conselho e finalmente a presidenta do movimento Yara Goes, presidenta também da Ação Local Amaral Gurgel. 
A maior parte das discussões nesses espaços de representação gira em torno de problemas sobre zeladoria, segurança e saúde pública do centro da cidade, denunciando "degradação ambiental" e "decadência" no bojo das discussões sobre a "revitalização" do Elevado.

Dentro da pluralidade de conselhos acima citados cabe aqui discutir dois deles: os Conselhos de Segurança (CONSEG) e as Ações Locais. Os CONSEGs foram criados nos municípios do estado de São Paulo e bairros da capital por Decreto Estadual em 1985 (n. 23.455/1985), buscando aproximar a Polícia Civil e Militar da sociedade civil para prevenção e combate à criminalidade. Cada conselho é uma entidade de apoio à Polícia Estadual, conformado pelo comandante da Polícia Militar da área, o delegado da Polícia Titular do correspondente distrito policial e pessoas da comunidade. Os objetivos destes conselhos giram, portanto em torno da segurança pública e formas de controle social.

As Ações Locais foram criadas no programa de mesmo nome em 1995 sob pressão da Associação Viva o Centro, na segunda gestão de Paulo Maluf (1993-1997). Neste programa, o centro da cidade de São Paulo foi dividido em 50 microrregiões e com base nessa divisão foram organizados os núcleos de participação de moradores e proprietários, chamados de Ações Locais. O objetivo desses núcleos é "exercer intensa vigilância sobre as condições urbanas de sua área específica, registrando os problemas, denunciando-os aos órgãos públicos competentes e deles cobrar soluções" ${ }^{35}$ visando "recuperar" o centro da cidade. Cada um dos núcleos é dirigido por um Conselho de Participação Local. Especificamente, a Ação Local Amaral Gurgel, presidida por Yara Goes, foi fundada em 2009, visando melhorias e zeladoria na Av. Amaral Gurgel. Sobre a constituição da Associação Viva o Centro, Kara José (2010) escreve:

Preenchendo uma lacuna deixada pelo poder municipal, cresceu nesta época o papel de um ator do setor privado, a Associação Viva o Centro (AVC), criada em 1991 pelo Banco

45. Viva o Centro: Programa Ações Locais (link para site na bibliografia). 
de Boston. O grupo congregava representantes de diversas instituições, a maioria proprietária de imóveis no Centro, entre elas as duas bolsas (de Valores e de Mercadorias \& Futuros), bancos nacionais, internacionais e públicos, Federação do Comércio, Associação Comercial, Federação das Indústrias, Rotary Club, Associação das Empresas de Crédito, Financiamento e Investimento, Associação das Empresas Distribuidoras de Valores, Federação Brasileira das Associações de Bancos (FEBRABAN), Associação Brasileira de Bancos Internacionais, Sindicato dos Bancários. Segundo Henrique Meirelles, então presidente do Banco de Boston, a ideia de criação da AVC teria surgido após conhecer a experiência ocorrida no Quincy Market, no centro de Boston, nos Estados Unidos. A região era completamente degradada, conhecida como combat zone (zona de combate) devido ao domínio de traficantes e agentes do crime organizado. No início da década de 60 , obras de renovação realizadas com a participação do poder público e de empresários transformaram o local perigoso em área de lazer e turismo, ao remover a população de baixa renda aí residente; ou seja, um modelo de gentrificação (Kara José, 2010, pp. 29-30).

Para além da contínua oposição à Associação Parque Minhocão nos meios de comunicação e nas audiências públicas, o movimento avançou objetivamente na realização de dois inquéritos civis que limitaram as atividades sobre o Minhocão. O primeiro deles (Inquérito Civil n. 14.279.295/15), obtido por meio de representação do MDM junto a quatro CONSEGs e endossado pelo Comando do Policiamento da Capital e Comando do Corpo de Bombeiros, cancelou as atrações marcadas para a Virada Cultural sobre o Elevado no ano de 2015 por falta de segurança. Deste inquérito, resultou um Termo de Ajustamento de Conduta (TAC) do Ministério Público do Estado de São Paulo (MPE) Promotoria de Justiça de Habitação e Urbanismo - que suspendeu eventos pela falta de atendimento às condições mínimas de segurança (guarda-corpos com altura mínima de 1,30m e saídas de emergência). O segundo (Inquérito Civil n. 14.279.153/2016), instaurado também a partir de representação dos membros dos CONSEGs, proibiu à municipalidade a realização de qualquer atividade para fim diverso daquele de tráfego de veículos devi- 
do à falta de segurança à população usuária e à perturbação do sossego dos moradores vizinhos. Portanto, desde 2016, graças à ação coordenada do MDM eventos oficiais ou com o apoio da prefeitura, principalmente eventos de grande porte, foram proibidos sobre o elevado, entre eles os desfiles de Carnaval. Apesar de fraca mobilização nas mídias sociais, sem perfil no Instagram e página no Facebook com cerca de 700 "curtidas", o MDM conseguiu em 2018 junto aos vereadores Caio Miranda (PSB) e Camilo Cristófaro (PSB) a elaboração de dois projetos de lei (PL n. 98/2018 e PL n. 336/2019), que visam a realização do desmonte do Elevado João Goulart e revogam a lei do Parque Minhocão. No próximo item, analisaremos estas leis e projetos.

\section{Movimento São Paulo sem Minhocão}

Finalmente, devemos destacar um terceiro grupo chamado Movimento São Paulo sem Minhocão (MSPSM), também não formalizado e a favor do desmonte do Minhocão. O MSPSM busca divergir do MDM enquanto grupo progressista desvinculado do passado e preocupado desde o princípio com a possibilidade de "gentrificação" que a região poderia sofrer sendo o Elevado transformado em parque. Organizaram dois debates na Câmara dos Vereadores em torno do chamado Fórum de Diálogo Sobre o Futuro do Minhocão e, também em 2014, ajudaram a elaborar um manifesto contra a gentrificação com participação da jornalista Sabrina Duran ${ }^{46}$, no qual denunciaram a apropriação do espaço público pelo privado, principalmente associada à ação do mercado imobiliário ${ }^{47}$.

Sem um perfil próprio nas mídias sociais, o grupo gerencia um espaço de discussão "público" com cerca de 1800 participantes no Facebook, criado no dia 11 agosto de 2014, data que inaugura a sua atuação. Neste espaço e nas audiências públicas, as pessoas

\footnotetext{
46. Sabrina Duran é jornalista e fundadora do projeto "Arquitetura da Gentrificação", em parceria com a Reporter Brasil, que visa denunciar medidas de higienização social adotadas pelas administrações municipais, investigando relações entre poder público e empresas privadas.

47. Disponível nos arquivos do grupo de discussão do Facebook.
} 
que se destacam são: o arquiteto Alexandre A. Moreira; a gestora Elisa Freire Moreau; o engenheiro, ativista e um dos fundadores da Associação pela Mobilidade a Pé em São Paulo (Cidade a pé) Gilberto de Carvalho; o psicólogo e fotógrafo João Batista Lago; o jornalista e curador Thiago Carrapatosom e a filósofa Valéria Farhat. Com pouca presença nos canais de comunicação, o grupo não tem atuação próxima de nenhum vereador, mas milita por um futuro progressista para a região.

\section{Vereadores}

Diversos vereadores, representantes da sociedade civil na Câmara Legislativa, se envolveram ao longo das décadas com a transformação do Minhocão. O primeiro deles a propor a transformação da área em parque foi o vereador Aurélio Nomura (PSDB) em 2005, cujo mandato não analisaremos neste item, tendo em vista que ele se retirou dos debates posteriores sobre o destino da estrutura. Após este primeiro projeto, o próximo seria aquele que instituiu o Parque Municipal do Minhocão (PL n. 10/2014), proposto pelos vereadores José Police Neto, Nabil Bonduki, Toninho Vespoli, Ricardo Young, Goulart, Natalini, promulgado por lei em 2018. Conforme afirma matéria da revista Veja São Paulo de dezembro de $2016^{48}$, e confirmado nas nossas entrevistas, a via da transformação do Elevado em parque seria encabeçada majoritariamente pelos vereadores Nabil Bonduki e Police Neto. O primeiro também responsável pela relatoria do PDE, que institui a desativação gradual do Elevado e o segundo, autor de uma série de outros projetos de lei que envolvem a estrutura.

No campo oposto, explorando a via da demolição, devemos destacar a atuação recente dos vereadores Caio Miranda e Camilo Cristófaro, envolvidos na elaboração de dois projetos de lei que buscam avançar neste caminho.

48. Veja SP. Comissão da Câmara Municipal aprova fim do Minhocão. 5 de dezembro de 2016 (link para site na bibliografia). 
Devemos ressaltar também que existem outros vereadores quebuscaram se aproximar da pauta, já que o tema gerou ao longo do tempo grande atenção dos veículos de comunicação. Contudo, cabe a este trabalho focar naqueles que polarizaram o debate. A seguir ,analisaremos brevemente os mandatos dos vereadores Nabil Bonduki, Police Neto, Caio Mirando e Camilo Cristófaro como agentes públicos, representantes de setores da sociedade civil, envolvidos ativamente na elaboração de leis que envolvem a transformação do Elevado a partir do PDE de 2014.

\section{Vereador Police Neto}

José Police Neto assumiu o seu primeiro mandato na Câmara dos Vereadores da cidade de São Paulo em 2005, na época pelo Partido da Social Democracia Brasileira (PSDB). Antes disso, Police Neto presidiu o diretório municipal do PSDB e coordenou as campanhas de governador de Mário Covas. Em 2011, filiou-se ao recém-criado Partido Social Democrático (PSD).

Segundo seu perfil no portal da Câmara Municipal, o vereador "atua intensamente nos assuntos que dizem respeito à qualidade urbanística na cidade", "ligados às áreas de mobilidade, habitação, revitalização dos espaços públicos e planejamento urbano"49. A sua participação ativa na Comissão de Política Urbana, Metropolitana e Meio Ambiente atesta esses interesses. As leis e os projetos por ele propostos se pautam principalmente em dois temas: mobilidade urbana e projetos que dizem respeito à função social da propriedade e destinação de propriedade para empreendimentos para baixa renda. No primeiro caso, podemos enquadrar: o Estatuto do Pedestre (Lei n. 16.673/2017), o Programa Bike SP (Lei n. 16.547/2016), além do projeto de lei que regulamenta o compartilhamento de automóveis na cidade de São Paulo (PL n. 421/2015). Sobre as leis que tratam da função social da propriedade, destacam-se: a Lei da Função Social da Propriedade Urbana (Lei n. 15.234/2010), a Lei de Regularização

49. Perfil na página web da Câmara Municipal de São Paulo: José Pólice Neto (link para site na bibliografia). 
Fundiária (Lei n. 15.720/2013), Lei do Retrofit Social (Lei n ${ }^{\circ}$ 16.056/2014), Lei do Consórcio Imobiliário de Interesse Social (Lei no $16.377 / 2016$ ) e projeto de lei para locação social (PL 258/2016) ainda em tramitação.

Neste contexto, o vereador atuou ativamente pela implantação do Parque Minhocão, tendo participado da reunião inaugural da Associação Parque Minhocão e elaborado as seguintes leis e projetos de lei: a lei que altera o nome do Elevado para Parque Minhocão (Lei n. 16.397/2016), a lei que cria o próprio Parque Municipal Minhocão (Lei n. 16.833/2018) e os projetos de lei que alteram o horário de funcionamento do elevado (PL $\mathrm{n}$. 22/2015) e que instituem o "Museu de Arte Urbana Minhocão' (PL n. 259/2016). Dentro dos canais de comunicação, o vereador tem bom trânsito na revista Veja, tendo sido eleito por ela como o 'Melhor Vereador em 2008'. Atualmente, Police Neto se encontra no 4 a mandato consecutivo, tendo presidido a Câmara Municipal nos anos 2011 e 2012.

\section{Vereador Nabil Bonduki}

Arquiteto e Urbanista, professor na Faculdade de Arquitetura e Urbanismo da Universidade de São Paulo (FAU USP), Nabil Bonduki assumiu o primeiro mandato em 2001 pelo Partido dos Trabalhadores (PT) e o segundo em 2013 pelo mesmo partido. Durante seus dois mandatos como vereador (2001-2004 / 20132016) coordenou na posição de relator o processo de aprovação dos Planos Diretores de 2002 e de 2014 respectivamente. Antes disso, participou ativamente dos debates em torno da reforma urbana, que discutimos no item anterior, tendo participado da elaboração da Emenda de Iniciativa Popular pela Reforma Urbana como presidente do Sindicato dos Arquitetos de São Paulo (SASP). Durante a gestão de Luiza Erundina, chefiou a Superintendência de Habitação Popular do município, em 2011 exerceu a função de secretário de Recursos Hídricos e Ambiente Urbano do Ministério do Meio Ambiente e em 2015 foi nomeado pelo então prefeito Fernando Haddad Secretário Municipal de Cultura de São Paulo. 


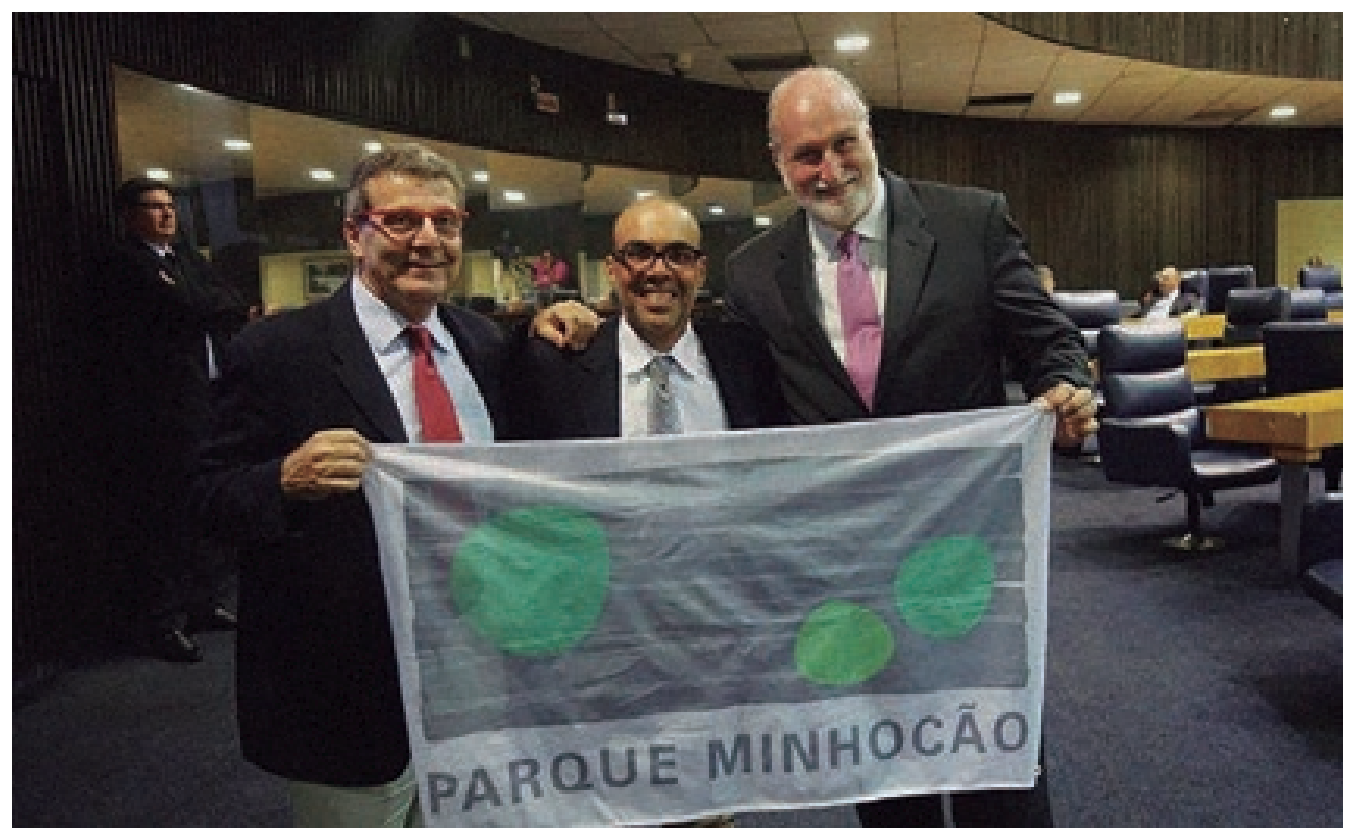

Na publicação síntese do segundo mandato, intitulada Por uma Cidade Aberta, Bonduki divide os projetos de lei, apresentados em três eixos: Política Urbana (incluindo urbanismo, mobilidade e habitação), Meio Ambiente e Cultura. No primeiro eixo, podemos destacar o Programa Ruas Abertas que discutimos no item anterior (Lei n. 16.607/2016), diversos projetos de lei de apoio à mobilidade ativa - principalmente para a expansão do sistema cicloviário (PL n. 7/2013, PL n. 561/2010, PL n. 655/2009) e projetos de lei que tratam da produção de habitação autogestionada, como a Lei da Autogestão na Moradia (Lei n.16.587/2016) e a Lei de Assessoria Técnica (Lei n.13.433/2002), além de ser coautor junto a Police Neto da Lei do Consórcio Imobiliário de Interesse Social (Lei no 16.377/2016). No eixo meio-ambiente, os projetos de lei estão ligados ao incentivo à produção e consumo de alimentos orgânicos, como a lei que institui a inclusão de produtos orgânicos na alimentação escolar (Lei n. 16.140/2015), ao consumo "racional" dos recursos naturais, aprimoramento da gestão dos resíduos sólidos e diminuição dos agentes prejudiciais ao meio ambiente (Lei n. 16.172/2015, Lei n. 13.782/2004, PL 591/2013, PL 125/2004), além de implementar a gestão participativa das Praças (Lei n. 16.2012/2015). Nos projetos de 
lei ligados à cultura, Bonduki propôs leis de incentivo à cultura de forma ampla, entre elas o Programa de Valorização de Iniciativas Culturais (Lei 13.540/2003), Programa Municipal de Fomento à Dança (Lei n. 14.071/2005), incentivos ao cinema (Lei n. 13.712/2013, PL n. 359/2004) e música (PL n. 376/2016, PL n. 399/2016).

Ao lado de Police Neto, foi também autor da lei que criou o Parque Municipal do Minhocão (Lei n. 16.833/2018), e também prestigiou o ato da fundação da Associação Parque Minhocão. Em entrevista, Bonduki afirma ser ele quem levou, enquanto relator do Plano Diretor de 2014 , a pauta da desativação do Elevado ao então prefeito Fernando Haddad durante as discussões do PDE. Bonduki também foi membro da Comissão de Política Urbana, Metropolitana e Meio Ambiente. Amplo defensor de modelos de gestão participativa e dos planos enquanto pacto com a sociedade civil, na síntese do seu segundo mandato, Nabil destaca a sua "capacidade de ouvir os diferentes segmentos da sociedade, traduzindo suas reivindicações em soluções técnicas, mediando conflitos e pactuando uma proposta final coerente e que dá rumo para a cidade".

\section{Vereador Caio Miranda}

Advogado, Caio Miranda assumiu seu primeiro mandato em 2017 com 34 anos de idade pelo Partido Socialista Brasileiro (PSB) tendo anteriormente apenas presidido o centro acadêmico da Faculdade de Direito da Universidade de São Paulo e trabalhado como assessor jurídico no Tribunal de Contas do Estado (TCE $\mathrm{SP})$ no combate à corrupção. No seu website $\mathrm{e}^{50}$, ele se autodeclara blogueiro, tendo sido eleito por meio de "campanha digital".

Em suas linhas de atuação, declara-se atuante em projetos de mobilidade, sustentabilidade, desburocratização e eficiência da máquina pública. Dentro dessas linhas podemos destacar, por um lado, projetos de lei que tratam da sustentabilidade - lei que institui a inspe-

50. Página web de Caio Miranda Carneiro (link para site na bibliografia). 


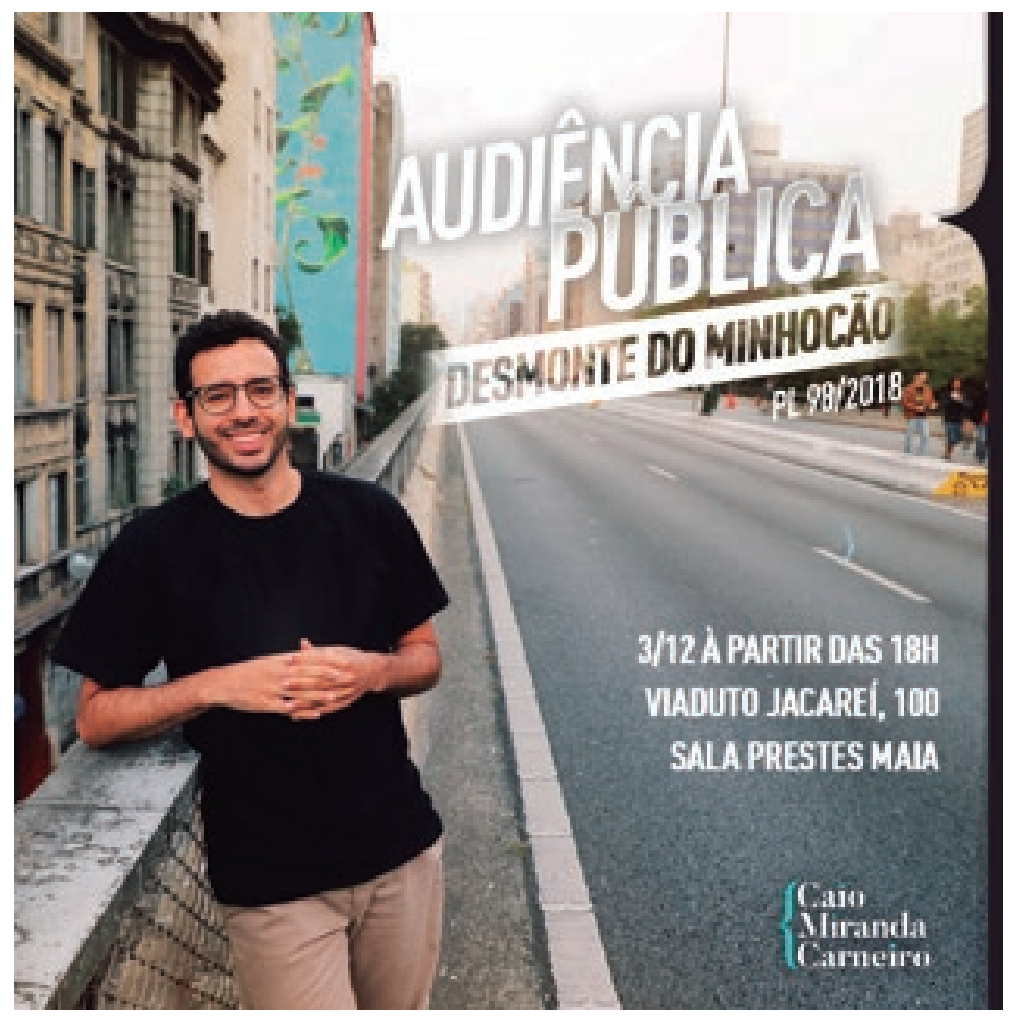

ção veicular no transporte público e de carga do município (Lei n. 16.912/2018), lei que institui o programa municipal de Implementação da Agenda 2030 (Lei n. 16.817/2018), projeto de lei que cria critérios de sustentabilidade nas licitações (PL 724/2017) — e por outro lado, aqueles que tratam de mecanismos de transparência e combate à corrupção - projeto de lei que cria o "selo anticorrupção" para empresas (PL 722/2017), projeto de lei que prevê a adoção de critérios ligados ao combate à corrupção nas licitações públicas (PL 723/2017).

Em 2018, Miranda apresentou projeto de lei que dispõe sobre o desmonte do Elevado e a requalificação do seu entorno (PL n. 98/2018) em resposta à aprovação da lei que instaurou o Parque Minhocão, aprovada em fevereiro do mesmo ano. Sobre projetos de lei que tratam de espaços públicos, não constam muitos projetos da sua autoria; podemos citar: a lei que aplica sanções à pessoa que urina em locais públicos (Lei n. 16.647/2017), a lei que permite que praças sejam geridas com a participação de
Fig. 2.2.2

Divulgação de Caio Miranda Carneiro da audiência pública do PL n. 98/2018 pelo desmonte do Minhocão. S/n, 2018. 
empresas e associações privadas (Lei n. 16.868/2018) e o projeto que regulamenta as feiras de arte, artesanato e antiguidades em áreas públicas (PL n. 599/2017).

Podemos entender a atuação de Miranda como um novo ator que representa, dentro do Legislativo, setores da sociedade que preferem a demolição do Minhocão em resposta à lei que instituiu o Parque Municipal do Minhocão. Diferentemente de Nabil Bonduki, Police Neto e Camilo Cristófaro, Caio Miranda não é membro da Comissão de Política Urbana, Metropolitana e Meio Ambiente da Câmara Municipal.

\section{Vereador Camilo Cristófaro}

Camilo Cristófaro assumiu pela primeira vez como vereador em 2017 junto ao também advogado Caio Miranda, colega de bancada no PSB. Antes disso, foi Procurador do Estado (1991-1992), presidente da Companhia de Engenharia de Tráfego (CET), chefe de gabinete da Mesa Diretora da Câmara Municipal de São Paulo (CMSP) e diretor da Empresa de Tecnologia, Informação e Comunicação do Município de São Paulo (PRODAM). O programa eleitoral para o mandato de vereador se baseou na denúncia à chamada "Indústria da Multa", principalmente por meio de vídeos divulgados nas mídias sociais.

Na Câmara, Cristófaro é membro da Comissão Permanente do Idoso e de Assistência Social e da Comissão de Política Urbana, Metropolitana e Meio Ambiente. Seus projetos de lei tratam de questões diversas sem eixos claros declarados, como: projeto de lei que proíbe o fornecimento de canudos plásticos (PL n. 99/2018), projeto que obriga a previsão de pontos de tomada elétrica em vagas de veículos em condomínios (PL n.387/2018), projeto que cria o Plano Municipal da Primeira Infância (PL n. 27/2017), projeto que prolonga por dois anos o prazo para solicitação de regularização e reformas em edificação (PL n. 543/2017) e projeto que dispõe sobre a instalação obrigatória de rastreadores de veículos de transporte escolar (PL. n. 143/2017). 


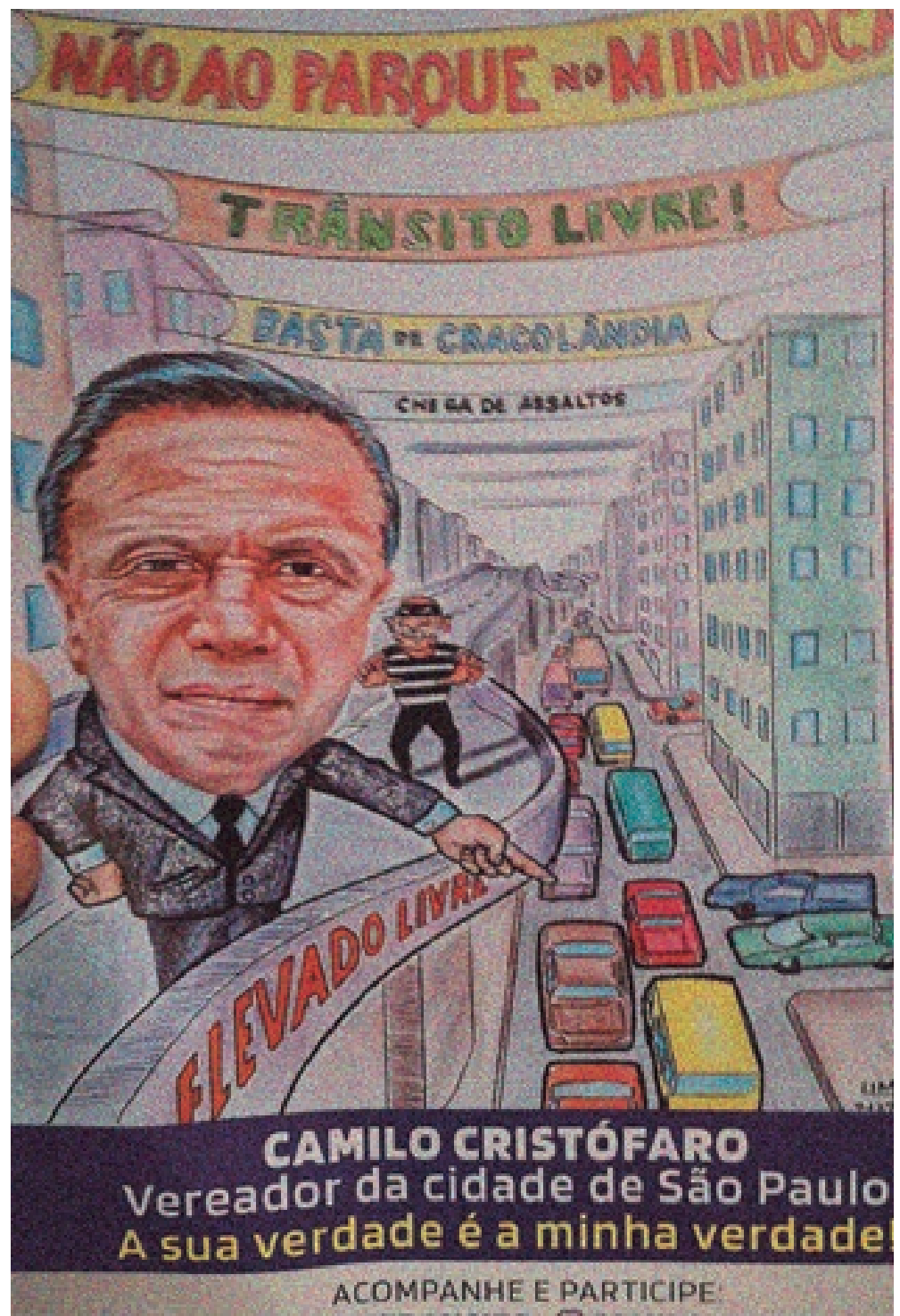

Ele é coautor do projeto de lei que dispõe sobre o desmonte do Elevado junto a Caio Miranda e, em 2019, apresentou projeto de lei que propõe a revogação da Lei n. 16.883/2018, que instituiu o Parque Municipal do Minhocão. Ao lado de Miranda, pautam o desmonte do Elevado na Câmara Municipal.
Fig. 2.2.3

Material de campanha do Vereador Camilo Cristófaro. Fotografia do autor, 2016. 
Em suma buscamos neste item mapear as diferentes organizações da sociedade civil que se organizaram em torno da transformação do Elevado durante as discussões do PDE de 2014 e após a sua promulgação. Verificamos como uma série de vereadores se articula e toma partido desta pauta não ficando claro até que ponto eles veiculam interesses legítimos públicos ou apenas aquilo que o "cidadão quer ouvir", na busca por angariar votos de um certo contingente populacional. Os grupos se organizam principalmente entre aqueles que querem a construção de um parque e aqueles que querem a sua demolição. $\mathrm{O}$ dissenso se estrutura aqui em torno da forma, que na essência se realiza enquanto um consenso: a transformação do espaço. Vimos um terceiro grupo que aparentemente foge desta dualidade-consenso, o São Paulo sem Minhocão, que parece estar mais preocupado em promover a discussão do que realizar uma articulação ampla em prol de seus interesses.

O texto escrito pelo membro da Associação Parque Minhocão nos parece sintetizar este movimento: "O desafio é reconstruir (...) a teia de relações sociais que (..) produza um consenso em torno do assunto (...). Em resumo, o desafio é abrir uma clareira que estimule a consolidação de uma esfera pública que legitime uma resposta, qualquer que seja (preferencialmente a nossa!)" ${ }^{1}$. Nesse sentido cabe aqui relacionar a ideia de consenso à de hegemonia nos moldes que aponta Brandão:

\footnotetext{
A hegemonia forja um bloco histórico, que pode compreender variados blocos políticos. Assim , bloco histórico é conformado por um "aliança de classes de longa duração" com capacitação política de dar coesão e unidade a forças heterogêneas, mitigando/contornando suas contradições. Esse conjunto de forças sociopolíticas assimétricas luta por ter capacidade de ser portador, de traçar um projeto, de dar universalidade a seus interesses específicos, coesionando os "subprojetos" das diversas frações de classe. Essa coalizão precisa construir sentido, legitimar seu poder e estender seus elos por todas as instituições e pelo tecido social (Brandão, 2012, p.85).
}

51. Levy, Wilson. Esfera pública, interesse público e o Parque Minhocão Vitruvius, fevereiro de 2014 (link para site na bibliografia). 
Mais adiante, no capítulo 3, buscaremos vincular a produção deste consenso em torno da transformação do espaço às redes de crescimento, ao vincular este movimento com o setor da propriedade. 


\section{Leis, planos e projetos para o Minhocão: entre o discurso e a intervenção efetiva}

Neste item, faremos um levantamento e análise das leis, planos e projetos que foram elaborados ou apenas anunciados pelo poder público, nas instâncias legislativas e executivas, destacando quais foram os principais atores que deram andamento para tais, as justificativas que motivaram a sua elaboração e as transformações diretas que eles realizaram no espaço. O levantamento foca, principalmente, naquelas leis e planos que se realizaram depois da promulgação do Plano Diretor de 2014 (Lei n. 16.050/2014) até o ano de 2019.

Sobre o PDE, devemos lembrar como nele se inseriu a necessidade de elaboração de uma lei específica para detalhar a forma pela qual se realizaria a "gradual restrição ao transporte individual motorizado" no Elevado. Dentro do capítulo do PDE que trata das Disposições Transitórias, por meio de uma emenda acrescida na câmara dos vereadores, foi escrito o seguinte artigo:

Art. 375. Ficam desde já enquadradas como ZEPAM: I - os parques urbanos municipais existentes;

II - os parques urbanos em implantação e planejados integrantes do Quadro 7 e Mapa 5 desta lei; III - os parques naturais planejados.

Parágrafo Único. Lei específica deverá ser elaborada determinando a gradual restrição ao transporte individual motorizado no Elevado Costa e Silva, definindo prazos até sua completa desativação como via de tráfego, sua demolição ou transformação, parcial ou integral, em parque. (Município de São Paulo, 2014, art. 375). 
Neste artigo, devemos destacar que as possibilidades contempladas eram tanto a demolição quanto a sua transformação em parque, delegando a uma lei específica o seu detalhamento. Porém a possibilidade de demolição viria a ser vetada pelo então prefeito João Dória na época da promulgação desta lei específica (2018).

Antes do PDE, devemos destacar as seguintes iniciativas do poder público, que impulsionaram a inserção desta pauta na esteira do ordenamento do desenvolvimento urbano:

\section{Lei n. 12.152/1996}

Promulgada no dia 24 de julho de 1996. Dispõe sobre o horário de funcionamento do Elevado Costa e Silva.

Proposta pelo vereador José Eduardo Cardozo (PT) por meio de um projeto de lei de 1995 (PL 1.560/1995), esta lei consolidou os horários de fechamento do Elevado para o trânsito de veículos motorizados que já vinham sendo praticados pela prefeitura desde a gestão de Luiza Erundina (1989-1992). Formalizou, portanto, o horário de segunda a sexta-feira das $21 \mathrm{~h} 30$ às $6 \mathrm{~h} 30$ e fechamento $24 \mathrm{~h}$ nos domingo e feriados.

\section{Projeto de Lei n. 664/2005}

Apresentado no dia 18 de outubro de 2005. Dispõe sobre a criação de um parque linear no Elevado.

Conforme mencionado no item anterior, este projeto de lei, apresentado por Aurélio Nomura (PV), dispunha sobre a criação de um parque linear sobre o então denominado Elevado Costa e Silva nos trechos entre a rua Traipu e a rua Ana Cintra, excluindo deste parque o trecho do Elevado sobre a Av. Amaral Gurgel. Como o próprio Comolatti afirma em entrevista, a ideia foi apresentada a Noemura tendo conhecimento de um projeto 
proposto pelo arquiteto Pitanga do Amparo ${ }^{52}$, divulgado na capa do Jornal da Tarde (1987) e o conhecimento do projeto para o High Line em Nova Iorque ${ }^{53}$. Este projeto de lei, diferentemente de outros, avançava em detalhes como a necessária implantação de escadas rolantes para acesso ao tabuleiro, a inclusão de pista de cooper e ciclovias e a realização de projetos específicos junto a comunidades de imigrantes que integram os "países e estados de origens dos habitantes da cidade”. No parecer de 2007 da Comissão de Constituição, Justiça e Legislação votou-se pela ilegalidade do projeto tendo em vista que "não pode o legislativo determinar a criação de determinado empreendimento".

\section{$2^{\circ}$ Prêmio Prestes Maia de Urbanismo Maio de 2006.}

O prêmio Prestes Maia foi instituído em 1997 (Lei n.

12.443/1997) na gestão Celso Pitta (1997-2001) por meio de um projeto de lei proposto na gestão de Paulo Maluf (1993-1996), tendo a sua primeira edição sido realizada em 1998. Nesta data, o projeto em questão tratava da realização de um plano de construção de piscinões na Bacia do rio Aricanduva. O prêmio deveria ser "outorgado quadrienalmente a propostas no campo do planejamento e da engenharia urbana" e o tema do prêmio seria determinado pela extinta Secretaria Municipal do Planejamento (SEMPLA). Na segunda ocasião do prêmio, gestão Gilberto Kassab (2006-2008), foram premiadas as "melhores propostas de solução para os graves transtornos ambientais e urbanísticos provocados pela construção do, então denominado, Elevado Costa e Silva, conhecido como Minhocão". Sucintamente, o projeto ganhador mantinha a ligação leste-oeste da cidade e acrescentava um segundo nível para a implantação do

52. O projeto do arquiteto Pitanga de Ampara previa a implantação de um parque nas laterais do tabuleiro e uma via dupla de transporte coletivo (bondes ou ônibus) no centro. Previa ainda a conexão com edifícios adjacentes para alimentar o parque elevado com programas comerciais implantados nos andares próximos ao Minhocão. Por não se tratar de um projeto de iniciativa do poder público, não cabe neste trabalho maiores detalhamentos.

53. Comolatti, Athos. Como o Minhocão me transformou em um ativista acidental. Esquina, 22 de dezembro de 2017 (link para site na bibliografia). 
parque, confinando a via expressa dentro de um túnel elevado. Previa ainda a construção de novos edifícios em lotes adjacentes à estrutura para realizar a transposição entre o solo da cidade e o parque. Neste projeto os ganhadores propunham a realização de uma "Operação Urbana Minhocão". Não cabe aqui uma análise aprofundada das outras propostas ganhadoras, nem dos motivos que levaram a tal decisão, mas apenas elencar os impulsos que o próprio poder público deu no sentido da transformação da área.

\section{Termo de referência para a formulação do projeto de lei da Operação Urbana Lapa-Brás}

Maio de 2010.

Em 2010, no termo de referência para contratação de empresa para subsidiar a formulação do projeto de lei da Operação Urbana Lapa-Brás foi inserido como um dos objetivos pretendidos para a transformação urbanística da região a "recuperação urbanística e paisagística das áreas próximas ao Elevado Costa e Silva” (São Paulo, 2010, p. 17). Nesta Operação Urbana, formulada durante a segunda gestão de Gilberto Kassab (2009-2012) mas que não chegou a ser apresentada à câmara municipal, pretendia-se, de forma geral, reunir em uma única operação três Operações Urbanas previstas no PDE de 2002: Água Branca, Diagonal Norte e parte da Diagonal Sul. As justificativas movidas para tal se baseavam principalmente na superação dos obstáculos à mobilidade que a ferrovia, ao sul do rio Tietê, trazia para o desenvolvimento urbano, além de buscar resolver os problemas de drenagem da região. O projeto propunha o rebaixamento da linha de trem e a abertura de uma avenida com "qualidades urbanísticas" no leito aberto de tal forma a oferecer uma alternativa ao deslocamento leste-oeste que permitiria a demolição do Elevado. Nas propostas preliminares para o "Subperímetro Centro", dentro deste termo, declarava-se que a demolição do Minhocão propiciaria o "espraiamento das qualidades do bairro de Higienópolis" (São Paulo, 2010, p. 38) para a região central e a "reinserção de conjunto de quadras que se estende ao longo de seu percurso" (São Paulo, 2010, p. 38). 


\section{Leis e projetos de leis pós PDE 2014}

A partir daqui, analisamos as leis, planos e projetos que se sucederam após a promulgação do PDE em 2014.

\section{Projeto de Lei n. 10/2014}

Apresentado no dia 05 de fevereiro de 2014. Cria o

Parque Municipal do Minhocão e prevê a desativação gradativa do Elevado Costa e Silva.

Apesar deste projeto ter sido promulgado lei em 2018 (Lei n. $16.883 / 2018$ ) procuramos aqui avaliá-lo ao início de nossa cronologia, tendo em vista ele se constitui como o primeiro de uma série de iniciativas concordantes ou discordantes envolvendo novos agentes do poder público. O projeto de lei em questão foi apresentado alguns meses antes da promulgação do PDE, quando o mesmo já se encontrava em discussão na CMSP. Cabe lembrar que em 2014 já havia surgido a Associação Parque Minhocão.

Este projeto de lei foi proposto pelos vereadores José Police Neto (PSD), Nabil Bonduki (PT), Toninho Vespoli (PSOL), Ricardo Young (PPS), Goulart (PSD), Natalini (PV) e Floriano Pesaro (PSDB), conformando uma frente realmente plural de partidos em prol da transformação do Elevado em parque. O projeto inicial previa a criação imediata do Parque Minhocão, mas de forma gradativa em termos de obras, além de instituir o incentivo a atividades culturais, esportivas e de lazer.

Nas justificativas mobilizadas para esse projeto, estão os "transtornos severos causados pela poluição sonora e atmosférica" 54 , o "caminho natural e salutar" 55 apontado pelos moradores ao "organizar diversas atividades nos períodos em que o Elevado permanece fechado ao tráfego motorizado" 56

54. Cidade de São Paulo, JPL 10/2014.

55. Idem.

56. Cidade de São Paulo, JPL 10/2014. 
e a "intensificação dos investimentos em transporte coletivo" ${ }^{17}$ (metrô e corredores de ônibus), que viabilizaram sua progressiva desativação.

Tendo em vista as dificuldades em cumprir o cronograma proposto e o parecer negativo da Comissão de Justiça sobre a não observância das competências legislativas no que diz respeito à impossibilidade deste poder criar parques, o vereador José Police Neto (PSD) em 2017 propôs um substitutivo (SPL 10/2014). A este projeto, por um lado se somaram os vereadores Eduardo Matarazzo Suplicy (PT), George Hato (PMDB) e Sâmia Bomfim (PSOL) e por outro se retiraram Gilberto Natalini (PV) e Floriano Pesaro (PSDB). Como vemos a seguir, neste substitutivo, além de se alterar o cronograma inicialmente sugerido para a desativação do Elevado, foi inserido um artigo que citou o Poder Executivo à elaboração de um Projeto de Intervenção Urbanístico (PIU). Com um caráter conciliatório entre as partes, este projeto deveria analisar tanto a hipótese da demolição do Elevado quanto a sua transformação em parque, além da necessária "adoção de instrumentos de controle da captura valorização imobiliária”, conforme:

Art. 4o - Compete ao Poder Executivo apresentar Projeto de Intervenção Urbanístico - PIU, por decreto ou por lei específica, considerando as particularidades locais, e também: I - a gestão democrática e participativa, nos termos da legislação em vigor, das etapas de elaboração, implantação, execução e avaliação do PIU, escutado o Conselho Municipal de Política Urbana - CMPU;

II - as seguintes hipóteses de destinação da área previstas no parágrafo único do art. 375 do Plano Diretor Estratégico do Município: a) a transformação parcial em parque; b) a transformação integral em parque; c) o desmonte da estrutura física; III - a adoção de instrumentos urbanísticos de controle e captura da valorização imobiliária decorrente das intervenções promovidas; pelo Poder Público na área de impacto desta lei (Muncípio de São Paulo, SPL 10, 2004). 
No andamento deste projeto de lei, foram realizadas duas audiências públicas: uma no dia 9 de setembro de 2014 e outra no dia 22 de outubro de 2017, ambas organizadas pela Comissão de Constituição, Justiça e Legislação Participativa da CMSP.

\section{Emenda 2712/2014 ao projeto de lei n. 467/2014 Apresentado dia 18 de dezembro de 2014.}

A emenda apresentada pelo vereador Police Neto para o orçamento do Município solicitava a transferência de $\mathrm{R} \$ 200.000,00$ para a "realização do evento Projeto Arte e Cultura nas Alturas com o objetivo de transformar no último domingo de cada mês o Elevado Costa e Silva - o Minhocão, em uma passarela de arte e cultura”.

\section{Projeto de Lei n. 22/2015}

Apresentado no dia 04 de fevereiro de 2015. Dispõe sobre o horário de funcionamento do Elevado Costa e Silva.

Enquanto o PL 10/2014 tramitava na câmara, o vereador Police Neto apresentou uma série de outros projetos de lei, buscando atender às demandas pela transformação do Elevado em parque. Este projeto de autoria do vereador Police Neto (PSD) solicitava a alteração da Lei n. 12.152/1996, anteriormente descrita, para estender os horários de fechamento do Elevado para o trânsito de veículos motorizados, acrescentando as $24 \mathrm{~h}$ dos sábados. O projeto de lei resultaria em audiência pública a ser realizada no dia 20 de setembro do mesmo ano mas foi cancelada pelo inquérito civil instaurado pelo Ministério Público que proibiu a realização do evento sobre o Elevado.

No andamento deste projeto de lei foram realizadas duas audiências públicas: uma no dia 28 de maio de 2015, organizada pela Comissão de Trânsito, Transporte, Atividade Econômica, Turismo, Lazer e Gastronomia e outra no dia 2 de abril de 2017, organizada pela Comissão de Constituição, Justiça e Legislação Participativa. 


\section{Projeto de Lei n. 259/2016}

Apresentado no dia 25 de maio de 2015. Institui o

"Museu de Arte Urbana Minhocão".

Este projeto de lei, também de autoria do vereador Police Neto (PSD), institui o "Museu de Arte Urbana Minhocão", a ser constituído por trabalhos nos 50 pilares que sustentam o Elevado. O projeto buscava "ampliar a abrangência dos princípios do direito à cidade", "valorizar a memória e identidade da cidade", destinando um valor "nunca inferior" a R \$ 5.000.000,00 para sua realização (por meio de fundos municipais, doações, parcerias e convênios).

\section{Lei n. 16.397/2016}

Promulgada no dia 9 de março de 2016. Altera o nome do Elevado para Parque Minhocão quando o mesmo permanece fechado para tráfego de veículos motorizados.

Também de autoria do vereador Police Neto (PSD), por meio de um projeto de lei apresentado em 2015 (PL 439/2015), esta lei alterou o nome do Elevado para Parque Minhocão quando fechado à circulação de veículos e no cabeçalho do projeto de lei anuncia: "nós, crianças, decidimos, e os vereadores decretaram". O projeto de lei de caráter altamente discursivo alegou "assegurar a todas as crianças moradoras da região o direito ao ar puro, a tranquilidade e ao espaço de lazer e cultura nos momentos em que vigorar a denominação referida no caput deste artigo" assegurando "a todas as crianças o pleno direito de sonhar e lutar pelo dia em que os direitos mencionados no parágrafo anterior tomem-se permanentes e inalienáveis". 
Lei n. 16.525/2016

Promulgada no dia 25 de julho de 2016. Altera o nome do Elevado Costa e Silva para Elevado João Goulart.

Proposta pelo vereador Eliseu Gabriel (PSB) por meio de um projeto de lei em 2014 (PL 288/2014) esta lei alterou o nome de Elevado Presidente Costa e Silva para Elevado Presidente João Goulart, repondo simbolicamente a democracia deposta no golpe militar de 1964. Na justificativa, o autor denunciou o ex-presidente Artur da Costa e Silva como responsável pelo "ordenamento de inúmeros crimes contra a nação", enquadrando o PL no artigo 5o da Lei 14.454/2007, que veda a denominação de vias com nome de "autoridade que tenha cometido crime de lesa-humanidade ou graves violações de Direitos Humanos".

\section{Lei $\mathbf{n} . \mathbf{1 6 . 8 3 3 / 2 0 1 8}$}

Promulgada no dia 7 de fevereiro de 2018. Cria o Parque Municipal do Minhocão e prevê a desativação gradativa do Elevado João Goulart.

A lei de 2018 finalmente promulgou a criação do Parque Municipal Minhocão na área do recém-chamado Elevado João Goulart. O projeto de lei que discutimos anteriormente (Projeto de Lei n. 10/2014) recebeu nesta lei alguns vetos que devem ser destacados: em primeiro lugar, declarando clara preferência do prefeito, foi retirado do leque de hipóteses a serem consideradas na elaboração de um futuro PIU o desmonte do Elevado. Além desse veto estratégico, o prefeito vetou a extensão do fechamento para o trânsito no período de férias escolares, o prazo para eleição para o conselho gestor do parque e a multa no caso do descumprimento da Lei. A promulgação desta lei gerou novamente grande repercussão nos diferentes meios de comunicação.

Desta lei resultou a gradativa ampliação dos horários de fechamento para o tráfego de veículos motorizados, obedecendo o cronograma constante no artigo 2: 
Art. 2 A implantação do Parque Minhocão será gradativa, com o progressivo aumento da restrição de tráfego, conforme o seguinte cronograma:

I - em até 30 dias a partir da sanção da lei: estender o fechamento para o trânsito aos sábados, domingos e feriados;

II - em até 90 dias a partir da sanção da lei: restringir o horário de funcionamento para tráfego de veículos motorizados nos dias úteis para o horário das $7 \mathrm{~h}$ às $20 \mathrm{~h}$.

III - (VETADO)

Parágrafo único. Fica o Executivo autorizado a realizar projetos pilotos para avaliação dos impactos, em períodos inferiores aos previstos no cronograma. (Cidade de São Paulo, 2018, art. 2)

Portanto o horário de fechamento para o automóvel ficou estabelecido da seguinte forma, até a data desta pesquisa: das $20 \mathrm{~h}$ às $7 \mathrm{~h}$ nos dias úteis e as $24 \mathrm{~h}$ nos sábados, domingos e feriados.

\section{Projeto de Lei n. 98/2018 Apresentado no dia 03 de maio de 2018. Dispõe sobre o desmonte do Elevado João Goulart ("Minhocão").}

Projeto de lei apresentado pelo vereador Caio Miranda (PSB) com apoio posterior de Mário Covas Neto (PODE) e Camilo Cristófaro (PSB) dispõe sobre o desmonte do Elevado João Goulart. Conforme vimos, na lei que instituiu o Parque Minhocão (Lei n. 16.883/2018), o então prefeito João Dória tirou do leque de hipóteses a serem consideradas no PIU o desmonte do Elevado. Situação que causou revolta de diversos setores que incentivavam a elaboração do PIU mas considerando todas as hipóteses. Neste PL, o vereador Caio Miranda procura se contrapor ao veto do prefeito, reinserindo na pauta a possibilidade do desmonte do Elevado por meio da elaboração de uma nova lei. A justificativa por ele mobilizada neste PL é que a criação do parque agravaria os problemas de poluição sob o Elevado, "gerando uma degradação ainda maior da região e seu entorno" 58 . 
Resultado deste projeto de lei, no dia 12 de agosoto de 2019 foi realizada uma audiência pública organizada pela Comissão de Constituição, Justiça e Legislação Participativa.

\section{Projeto de Lei n. 336/2019 \\ Apresentado no dia 28 de maio de 2019. Revoga a Lei n. $16.833 / 2018$.}

Neste projeto de lei, o vereador Camilo Cristófaro (PSB) propõe a revogação da lei que criou o Parque Municipal do Minhocão na mesma linha do projeto de lei anterior. O projeto argumenta sobre as dificuldades da administração pública manter o grande número de parques municipais e sobre a incapacidade do parque resolver os problemas urbanístico trazidos pelo Elevado: não propõe soluções nem para a população em situação de rua e nem para o controle da valorização imobiliária.

\section{Planos e projetos urbanos para o Minhocão e seu entorno}

Conforme vimos no primeiro item deste capítulo, a região que engloba o Minhocão está inserida, nos últimos dois Planos Diretores, dentro da Macroárea de Estruturação Metropolitana, na qual buscam-se concentrar as grandes transformações urbanas da cidade. No último Plano Diretor, esta macroárea foi dividida em três setores: (1) setor orla ferroviária e fluvial; (2) setor eixos de desenvolvimento e (3) setor central. No caso do Minhocão, este ficou atravessado parte dentro da Operação Urbana Centro, portanto dentro do setor central, e parte dentro do Setor Orla Ferroviária e Fluvial, especificamente dentro do subsetor chamado Arco Tietê. Após a gestão de Fernando Haddad, que chamou o Arco Tietê de "Arco do Futuro" com claras intenções associadas ao marketing político, o subsetor Arco Tietê não recebeu mais atenções, passando para o limbo da administração pública. A atual gestão João Dória / Bruno Covas (PSDB) concentrou então esforços para dar andamento a uma miríade de PIUs esparsos pela cidade e à revisão da Operação Urbana Centro, já 


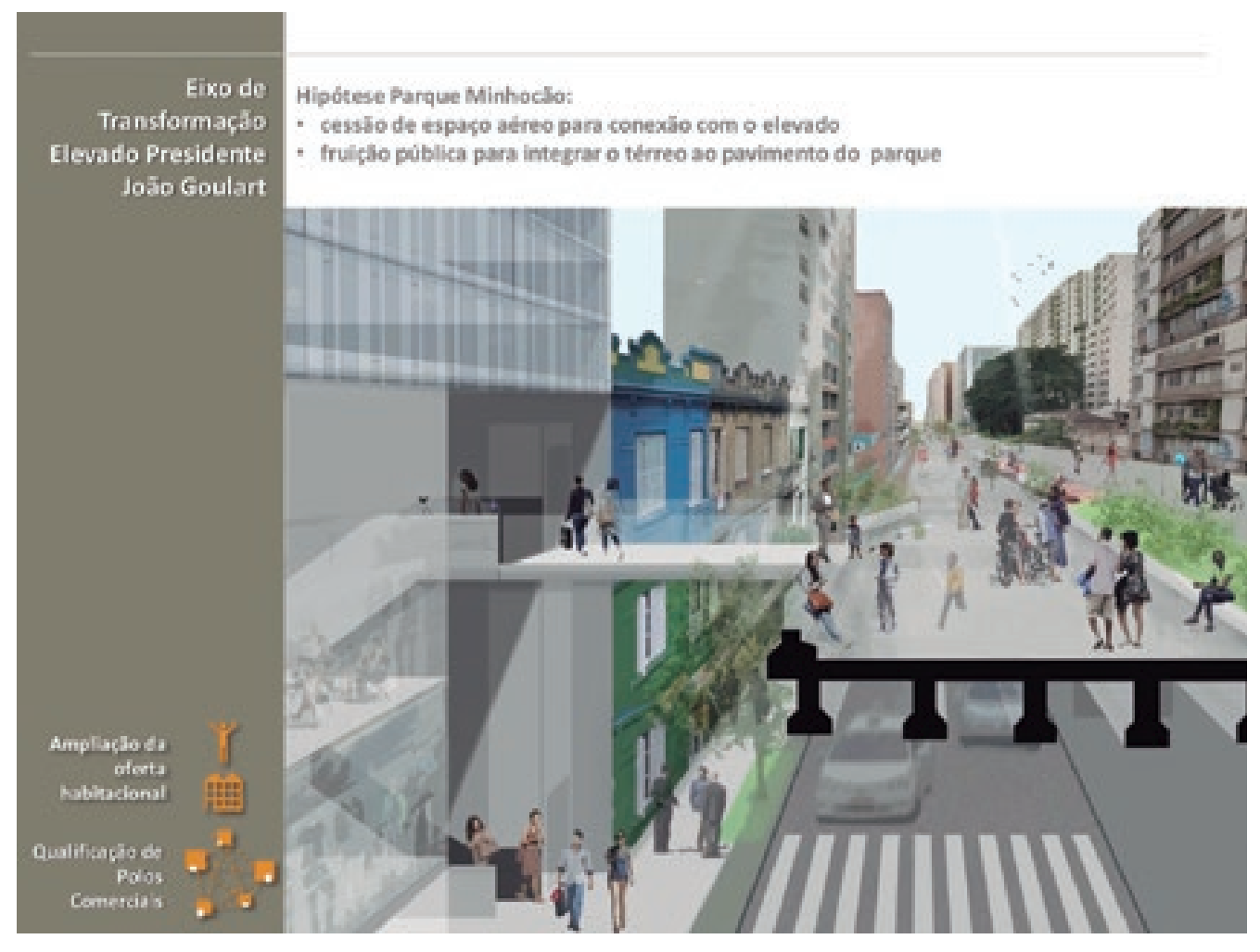

prevista no PDE (2014); Operação esta que foi englobada em um novo PIU chamado de PIU Setor Central. Seja no Arco Tietê, seja no PIU Setor Central, o Minhocão aparece como um projeto estratégico a ser desenvolvido em detalhes por um projeto específico.

Não cabe a este trabalho uma análise em profundidade do PIU Setor Central, mesmo porque ele se encontra em fase de discussões que ainda demandarão uma série de revisões. Contudo, cabe destacar que este PIU triplicou a área de abrangência da antiga Operação Urbana Centro ao incorporar parte do Arco Tietê - a margem sul deste rio associada ao centro da cidade - constituindo-se na segunda maior área em estudos para a transformação da cidade. Até a presente data, este PIU apresenta uma série de novos instrumentos não testados em outros marcos regulatórios da cidade. Especificamente sugere-se bônus em área computável adicional associados à produção de Habitação de Interesse Social (HIS) e ao restauro de edificações antigas pelo
Fig. 2.3.1

Eixo de Transformação Elevado Presidente João Goulart, apresentado na CTLU pelo PIU Setor Central. Gestão Urbana, 2020. 
privado, no lugar do pagamento de contrapartidas em dinheiro pela exploração do coeficiente de construção adicional. Bônus estes que deslocam para a esfera privada a provisão de habitação social em consonância com outros projetos de concessão urbanística. No sentido da concessão de terras, cabe reforçar a disponibilização de terras públicas por meio de chamamento de interessados.

Na imagem ao lado (fig. 2.3.1), que trata sobre o Eixo de Transformação Elevado Presidente João Goulart, verificamos parte da apresentação realizada na Câmara Técnica de Legislação Urbanística (CTLU) na última fase do PIU Setor Central. Apesar de não ser a primeira vez que se sugere a incorporação de edifícios às margens do Elevado para realizar a transposição entre as cotas verticais, a imagem aponta a incorporação de áreas de edifícios privados para o parque por meio da cessão de espaço aéreo. Por se tratar ainda de uma idéia abstrata não sabemos exatamente quais serão os reais impactos no espaço urbano nem os imóveis que serão selecionados para tal proposta. Relevante aqui é analisar como um projeto com esta área de abrangência, como o PIU Setor Central se detém a divulgar uma imagem que trata de uma escala tão próxima como a do edifício vizinho ao Elevado em questão.

Antes de avançarmos na análise do PIU Parque Minhocão devemos ainda citar que a transformação da região do Minhocão apareceu também dentro do Caderno de Propostas do Plano Regional da subprefeitura da Sé, dentro das diretrizes do perímetro de ação Santa Cecília. Nele sugere-se, sem mais detalhes, a apresentação necessária de propostas para o Elevado.

Neste subitem analisaremos dois projetos anunciados pelo poder público: o primeiro é o projeto do escritório de arquitetura do Jaime Lerner, publicado em matéria da revista Veja São Paulo (com direito à capa da edição) e divulgado no perfil do Facebook da Prefeitura de São Paulo com o seguinte título: "Prefeitura anuncia a criação do Parque Minhocão”. O Segundo plano trata dos estudos para a realização do PIU Parque Minhocão previstos na lei de 2018 (Lei n. 16.833/2018). 


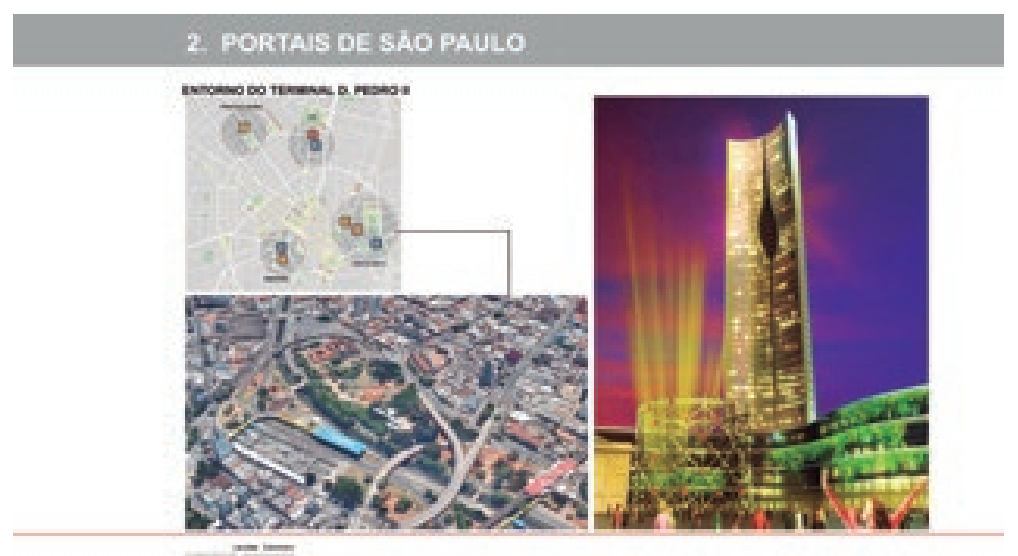

Fig. 2.3.2 llustração "Portais de São Paulo" do escritório de arquitetura Jaime Lerner sobre o projeto "Centro Novo".

Jaime Lerner, 2017

\section{PARQUE MINHOC $\bar{A} O$}

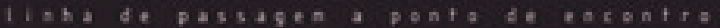

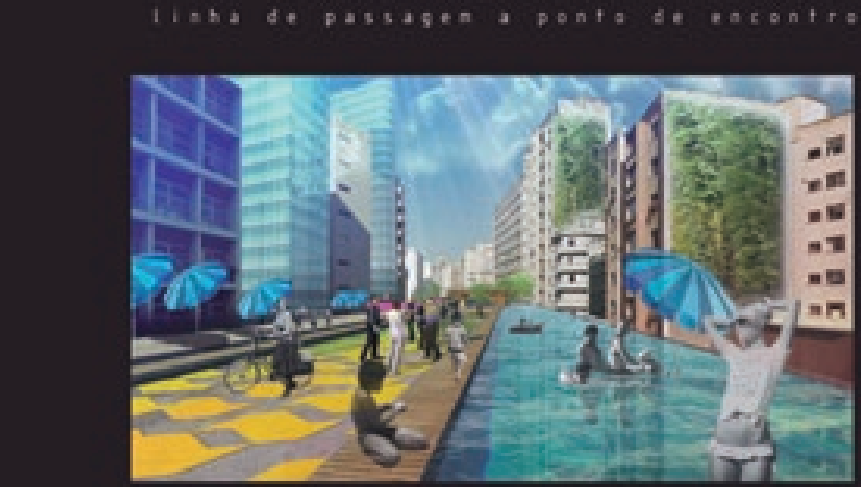

Fig. 2.3.3 Ilustração do projeto "Parque Minhocão" do escritório de arquitetura Jaime Lerner. Jaime Lerner, 2017.

\section{Parque Minhocão: linha de passagem a ponto de encontro - projeto do escritório Jaime Lerner Arquitetos Associados}

Obtido mediante lei de acesso à informação (LAI), o projeto chamado de "Parque Minhocão: linha de passagem a ponto de encontro" data do mês de maio de 2017, conforme capa de apresentação, e foi divulgado pela prefeitura no dia 21 de fevereiro de 2019, quase dois anos depois. Devemos contextualizar que, em agosto de 2017, a prefeitura assinou termo de cooperação (Termo n. 01/2017/SMUL) junto ao escritório de arquitetura acima citado e ao Sindicato de Empresas de Compra, Venda, Locação 
e Administração de Imóveis Residenciais e Comerciais de São Paulo (SECOVI-SP), prevendo a "elaboração de propostas para revitalização/requalificação da área central da cidade" (Processo SEI n.6068.2017/273-0). Aqui o setor público e os interesses monopolísticos, representados pelo SECOVI, assinam contrato, publicado em diário oficial, em torno da transformação do centro, cabendo ao escritório Jaime Lerner apenas a criação de uma imagem que comunique a comunhão a favor de ambos.

Um dos produtos deste termo de cooperação foi o projeto do escritório de arquitetura para o centro da cidade chamado "Centro Novo: uma visão para o centro de São Paulo", que data de setembro de 2017. O centro é neste projeto apresentado como "cosmopolita, multicultural e vibrante" e se vale de imagens, como: "uma metrópole superlativa" com "tesouros", infraestrutura de transportes, "cenários privilegiados do encontro" para estabelecer as seguintes "premissas estruturantes": prioridade à moradia, uso misto, diversidade, coexistência, primazia do pedestre, primazia da mobilidade coletiva e da mobilidade leve, rede de espaços públicos qualificados e memória, cultura e identidade. O projeto propõe sinteticamente: (1) uma rede de boulevards centrais (eixos de vida, trabalho e sociodiversidade); (2) "portais de São Paulo”(fig. 2.3.2) (grandes projetos urbanos icônicos em pontos referenciais da cidade); (3) dois circulares, construindo um anel em torno do centro antigo incluindo até mesmo o design do veículo; (4) acupunturas urbanas (requalificação de ruas, pocket-parks, "grafites de luz" e ativações do espaço público por meio de eventos diversos.

Levantamos aqui esse grande número de ideias com nomes apelativos por nos ajudarem a entender em qual contexto se insere o projeto para o Minhocão elaborado pelo mesmo escritório e entendendo que aqui a arquitetura aparece mais como um fluxo de figuras de linguagens carregadas de signos difusos, que apontam para todos os lados, do que como uma síntese moderna.

Neste contexto, a proposta para o Parque Minhocão apresenta o Elevado como figura cuja "presença deprime a qualidade ambiental e de paisagem, o comércio, as relações de vizinhança e o 

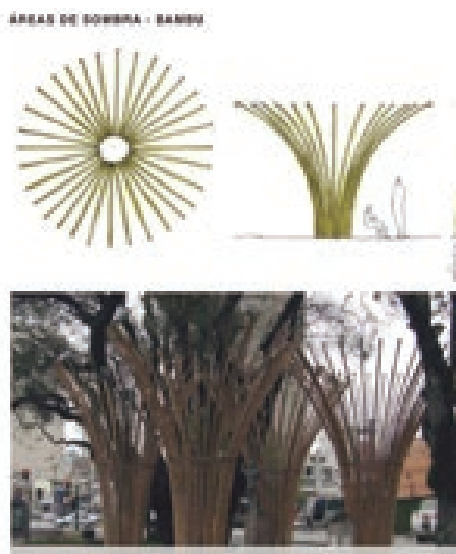

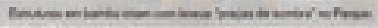

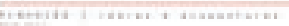

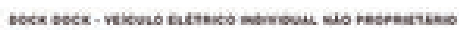
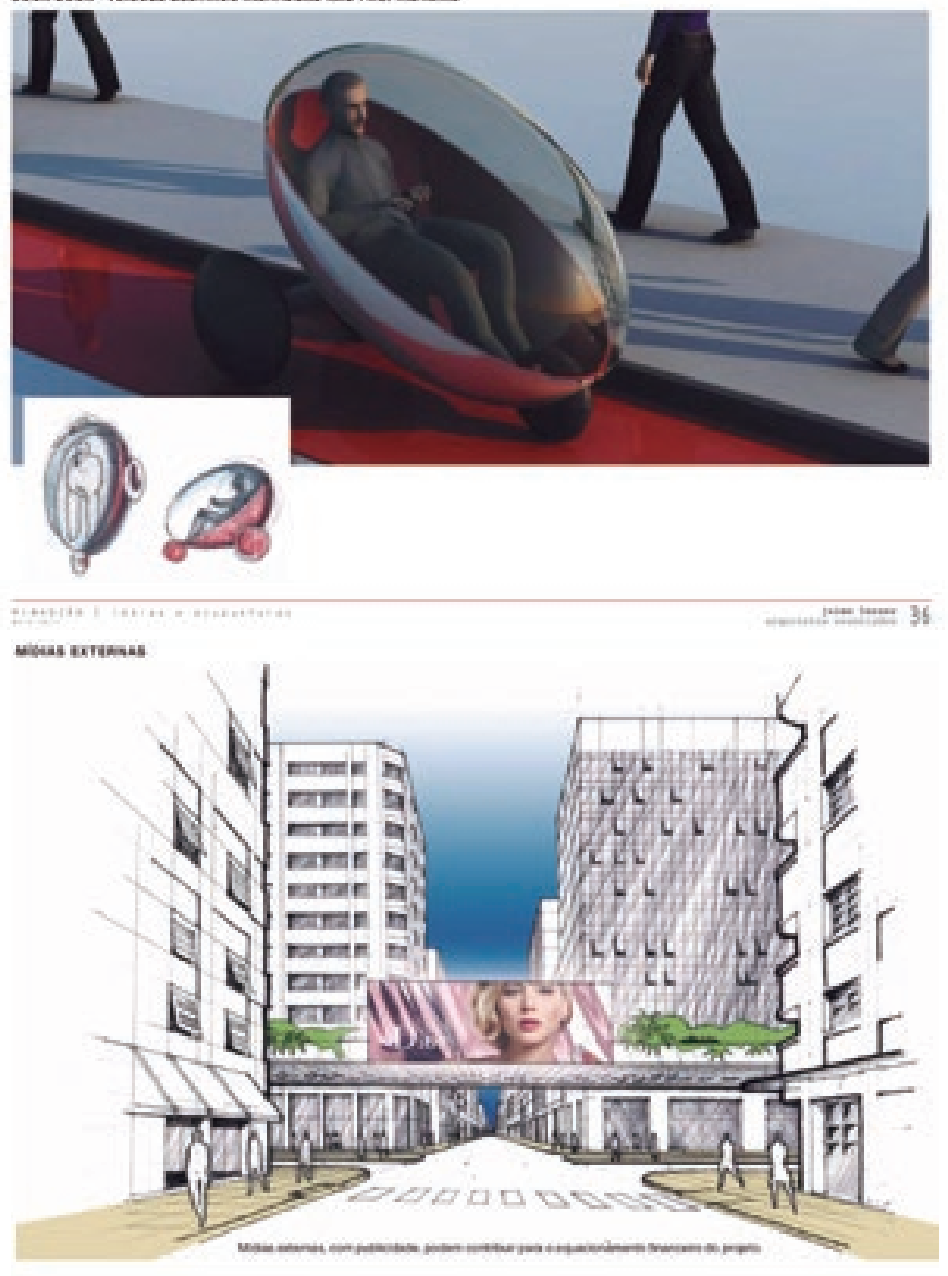

wain
Fig. 2.3.4

|llustração de sombreamento do projeto "Parque Minhocão" do escritório de arquitetura Jaime Lerner. Jaime Lerner, 2017.

Fig. 2.3.5

Ilustração de veículo elétrico do projeto "Parque Minhocão" do escritório de arquitetura Jaime Lerner. Jaime Lerner, 2017.

Fig. 2.3.6

Ilustração de espaços publicitários do projeto "Parque Minhocão" do escritório de arquitetura Jaime Lerner. Jaime Lerner, 2017. 
mercado imobiliário da região" que na atualidade se transformou em um "grande palco para expressões artísticas e culturais" sinalizando "a mudança de um lugar de passagem para um lugar de permanência": "uma praia urbana". O projeto (fig. 2.3.3) conta um um número expressivo de elementos que dificultam a sua síntese. Aqui elencamos uma seleção que acreditamos ser expressão do todo: vasos de plantas em elementos industrializados, implantação de passeio público de pedestres e ciclovia, mobiliário urbano diverso (sombreamentos em varas de bambu (fig. 2.3.4), módulos para comércio ambulante com design sofisticado, "veículo elétrico individual não proprietário" (fig. 2.3.5), sanitários públicos), praças culturais em containers, espaços publicitários (fig. 2.3.6), grafites de artistas consagrados no piso e um teatro na Praça Marechal Deodoro. Nas laterais se vale de terrenos subutilizados e edificações "degradadas" para a realização de novos empreendimentos associados ao Elevado por meio de passarelas na perspectiva de "recuperar o valor imobiliário": "o público e o privado formam uma parceria de benefício mútuo". Sob o tabuleiro, sugere-se além da instalação de placas acústicas e um novo sistema de iluminação a implantação de equipamentos de lazer e cultura (ateliês de artes plásticas, horta, teatro, música, dança e fablabs).

\section{Relatório do grupo de trabalho intersecretarial para estudos do PIU Parque Minhocão}

Divulgado em abril de 2019.

O processo para elaboração do PIU teve início em 2018 obedecendo a lei anteriormente discutida (Lei n. 16.833/2018), aprovada em fevereiro. O grupo de trabalho intersecretarial com o objetivo de "adoção de medidas prévias necessárias à elaboração de estudos e à apresentação de propostas tendentes à implantação do Parque Minhocão" foi instituído neste processo por meio de decreto promulgado no dia 15 de janeiro de 2019 (Decreto n. 58.601/2019). Tendo em vista que este PIU encontra-se ainda em fase de desenvolvimento, limitaremo-nos a discutir o relatório publicado por dito grupo de trabalho com a intenção de subsidiar os estudos do chamado "Parque Minhocão", divulgado em abril de 2019. Conforme declarado neste relatório, "o PIU 
tem por finalidade reunir e articular os estudos técnicos objetivando promover o ordenamento e a reestruturação urbana em áreas subutilizadas com potencial de transformação" (São Paulo, 2019, p. 56).

O relatório, com 158 páginas, divide-se em duas partes: a primeira de "contextualização e diagnóstico", e a segunda com "elementos de projeto para a implantação gradual do Parque Minhocão" além de dois anexos - um que busca contextualizar o objeto em termos históricos e outro que analisa referências de projetos urbanos semelhantes realizadas em outros lugares do mundo.

Na primeira parte do relatório, deixam-se claros os princípios orientadores, que podemos sintetizar como a qualificação dos espaços públicos, a promoção da inclusão, o atendimento a populações vulneráveis e a implantação do projeto de forma gradual. Na sequência declaram-se as premissas básicas; dentre elas cabe reforçar o estímulo a parcerias com o setor privado e a sociedade civil na implantação e gestão do parque.

Por último, busca-se caracterizar e realizar um diagnóstico do perímetro em termos de mobilidade e incomodidade urbana (poluição sonora e ambiental), perfil socioeconômico, ambiental, uso do solo e diagnóstico institucional, além de citar projetos já realizados para a região ${ }^{59}$. Cabe destacar aqui que: (1) sobre a qualidade do ar, os estudos revelam que a média do material particulado analisado na região é de 3 a 4 vezes superior ao limite definido pela CETESB e pela Organização Mundial da Saúde (OMS) e que mesmo quando o Elevado está fechado para veículos os índices continuam altos e bem acima da média da capital paulista; (2) o relatório aponta, por meio de índice da fundação SEADE, que a vulnerabilidade social na região pode ser caracterizada como baixa; (3) levanta que a região central vem "crescendo em atratividade" com a retomada de lançamentos residenciais de unidades de menor área; (4) reconhece a presença de habita-

59. Nos referimos aos Ganhadores do $2^{\circ}$ Prêmio Prestes Maia, ao projeto Marquise Minhocão do escritório TripTyque e ao projeto do escritório Jaime Lerner. 
ções precárias por meio de levantamento de cortiços obtido do portal Habitasampa da SEHAB ${ }^{60}$, sem aprofundar demasiadamente nem em termos quantitativos nem qualitativos.

Na segunda parte, o relatório procede para definir os elementos de projeto para implantação do Parque Minhocão, divididos em três "eixos estratégicos": (1) eixo institucional; (2) eixo segurança e mobilidade; (3) eixo ativação dos espaços públicos. Aqui, é assumida sem maiores justificativas uma implantação gradual do parque, que seria iniciada nos $900 \mathrm{~m}$ situados no trecho entre a Praça Roosevelt e o Largo do Arouche, sobre a Av. Amaral Gurgel.

No eixo 1, o relatório divide estrategicamente o projeto para o Parque Minhocão em dois caminhos a serem tramitados de forma paralela e possivelmente independentes: o primeiro, vinculado ao PIU Parque Minhocão, trata especificamente do projeto do parque enquanto espaço público, que requer de um projeto. O segundo,vinculado ao PIU Setor Central, trata "dos instrumentos e dos institutos regulatórios próprios ao planejamento urbanístico municipal" (CIdade de São Paulo, 2019, p. 55). Essa estratégia, de dissociar o parque dos instrumentos de planejamento, facilitaria a aprovação da primeira parte mediante declarado decreto municipal, esquivando-se de uma tramitação morosa dentro da Câmara Municipal e permitindo uma implantação do parque mais acelerada. Se a lei do Parque Minhocão (Lei n. 16.833/2018) previa a "adoção de instrumentos urbanísticos de controle e captura da valorização imobiliária”, esse relatório aponta um caminho oposto: a implantação do parque dissociado destes instrumentos.

No eixo 2 (eixo segurança e mobilidade), trata-se de uma breve análise da situação estrutural do Elevado, do impacto no trânsito, das medidas mitigatórias em caso de fechamento de parte do Elevado ao tráfego de veículos motorizados e da implantação de

60. Portal Habita Sampa (link para site na bibliografia). 
dispositivos de segurança e acessibilidade ${ }^{61}$. Cabe reforçar que nas análises sobre o tráfego de veículos é apontado que o trecho onde pretende-se iniciar a implantação do parque concentra o maior número de viagens.

Por último, no eixo 3 (eixo ativação dos espaços públicos), tratam-se dos elementos para implantação do parque no trecho proposto. Sugere-se a implantação de mobiliário pré-moldado de baixo custo, conforme aquele sugerido pelo escritório de Jaime Lerner e já utilizado pela prefeitura em outras ativações de espaço público, como no programa Centro Aberto. Neste eixo, é assumida a necessidade das intervenções urbanísticas serem acompanhadas de projeto e ações setoriais - plano de abordagem socioassistencial, plano de habitação de interesse social, plano de segurança urbana, plano de programação cultural e de patrimônio, plano de monitoramento ambiental - porém por se tratar de um relatório inicial não se avança em profundidade em nenhum deles. É peculiar neste documento, pela sua especificidade com relação ao resto, o compromisso assumido pela prefeitura, quando trata da adoção de medidas para a segurança pública, sobre a instalação de câmeras de segurança doadas pela empresa de telecomunicações TIM chamadas de biosites.

Sobre o anexo que trata de demais referências para a elaboração do projeto, analisam-se os seguintes projetos: Parque High Line (Nova York/EUA), Coullée Verte René-Dumont (Paris/França) sobre extinta linha de trem elevada, renaturalização do Riacho Cheong Gye Cheon (Seul/Coreia do Sul), The Bentway, (Toronto/Canadá) de frente ao lago Ontário, The 606 (Chicago/EUA) sobre extinta linha de trem elevada e Seoullo 7017 (Seul/Coreia) do Sul sobre um elevado para automóveis. Todos esses projetos dizem respeito a parques em espaços que tinham anteriormente funções metropolitanas associadas a períodos industriais, nos quais o deslocamento era privilegiado sobre a permanência. Projetos que assumem funções associadas ao lazer e ao turismo em áreas em que se pretende muitas vezes adensar a cidade.

61. Em parte solicitados pelo MPE no TAC anteriormente referido - gradil de proteção e estruturas de acesso (escadas e elevadores). 


\section{Intervenções concretas no Elevado}

A seguir para concluir o nosso levantamento, destacamos três intervenções concretas que se realizaram no entorno do Minhocão, relevantes para o nosso trabalho: a implantação do corredor de ônibus na Av. São João, a implantação da ciclovia sob toda a extensão do Elevado e o edital de chamamento para implantação de jardins verticais nas empenas dos edifícios do entorno.

O corredor de ônibus na Av. São João foi uma obra da gestão Marta Suplicy (2000-2004), fruto de um amplo investimento em vias exclusivas ou segregadas de ônibus, que junto à implantação de bilhete único atestam o interesse da gestão em aprimorar os serviços de transporte público. O plano incluiu a implantação de quase $71 \mathrm{~km}$ de corredores, dentre eles o corredor São João/Lapa/Pirituba.

No caso da implantação da ciclovia embaixo do Minhocão, esta foi inaugurada em 2015, obra da gestão Fernando Haddad (2012-2016), responsável pela implantação de $262 \mathrm{~km}$ de ciclovias por toda a cidade. Ambas obras fazem parte portanto de planos mais abrangentes de redes de transporte que se instalaram em parte embaixo do Minhocão.

Finalmente, também na gestão Haddad foi realizado um chamamento público (Chamamento Público n. 01/SVMA/2015) para que condomínios no entorno do Minhocão se oferecessem para receber jardins verticais nas suas empenas voltadas para o Elevado. O chamamento foi regulamentado por decreto publicado em março de 2015 que permitia o uso de compensações ambientais para implantação de jardins verticais e telhados verdes. Neste caso, usaram-se recursos de compensação ambiental da incorporadora americana Tishman Speyer pelo desmatamento de 856 árvores na construção de três torres de apartamentos de alto padrão no Morumbi. A compensação foi utilizada para a instalação e manutenção, até 2018, de oito jardins verticais (fig. 2.3.7): o verde nas alturas pode ser, até a data de hoje, o mais próximo que se chegou até aqui de um parque elevado, impulso concreto para a efetiva- 


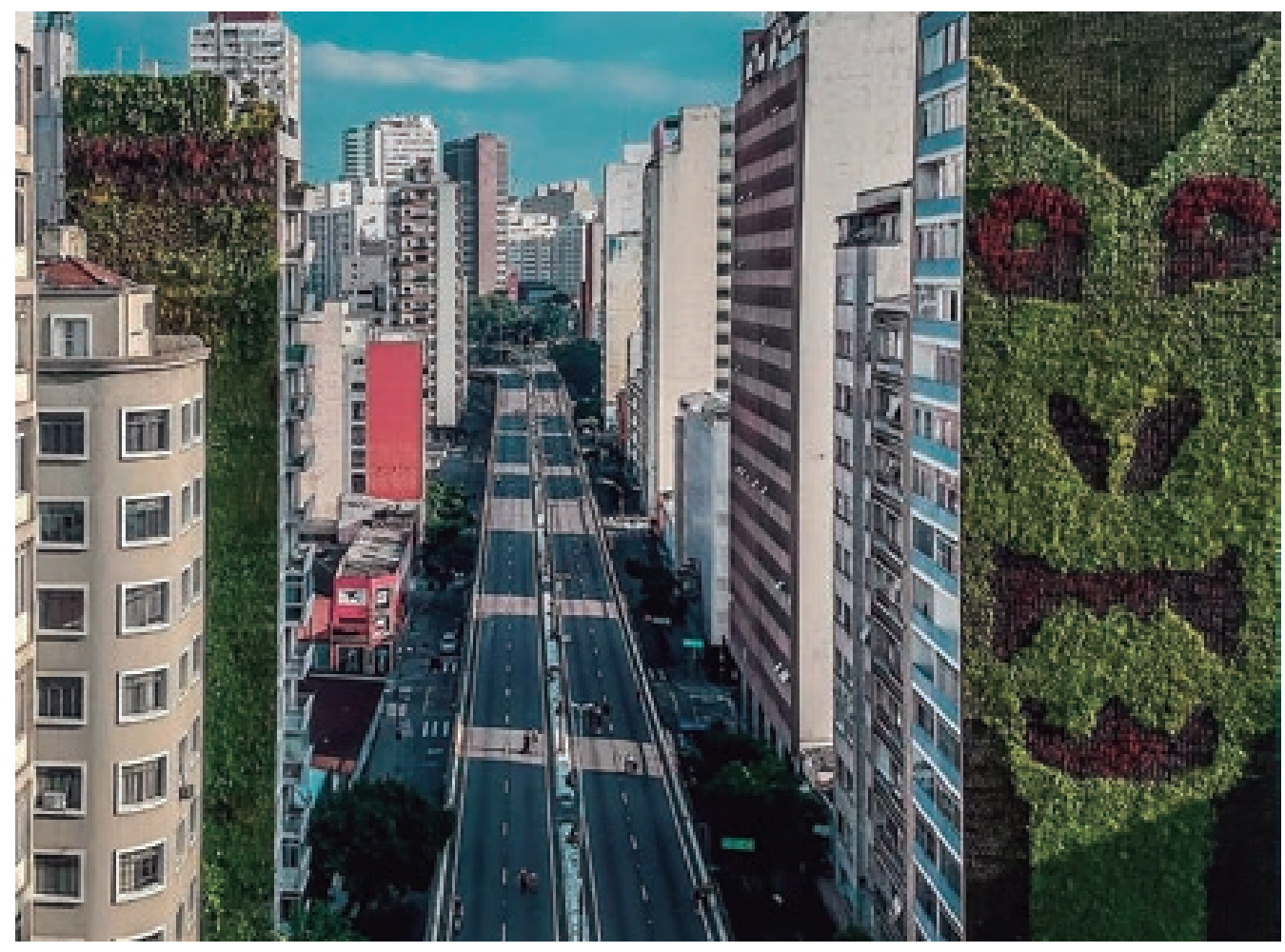

ção do Minhocão enquanto tal. Quando termo que previa a manutenção das empenas expirou a manutenção se tornou um custo difícil de arcar para os condomínios e na sequência alguns jardins verticais passaram a ser desmontados.

Fig. 2.3.7

Foto aérea do Minhocão. Rostey, 2019. 


\section{4}

\section{Impulsos virtuais}

A partir da década de 1990, quando o Minhocão passou a ser fechado para o tráfego de veículos motorizados aos domingos, novas formas de ocupação do espaço passaram a se efetivar sobre o seu tabuleiro de forma mais espontânea. Formas que em parte e gradualmente ocuparam a esfera institucional, como os eventos oficiais que passaram a ocupar este espaço a partir da Virada Cultural em 2005 (este assunto é abordado no no capítulo 1 desta pesquisa). A partir do século XXI, o que buscamos mostrar é que essas formas, mais ou menos institucionalizadas de ocupação do espaço, passaram para a esfera do planejamento urbano e para a tecnocracia estatal.

Ao longo do século XXI, foram apresentados 9 (tab. 2.4.1) projetos de lei, que dispõem sobre o Minhocão, sendo 8 propostos pela Câmara Municipal e 1 pelo Poder Executivo (PDE de 2014). Dos 8, 4 foram de autoria do vereador Police Neto (em alguns casos compartilhado com outros vereadores) e 2 foram de Camilo Cristófaro. Além destes projetos de lei, em duas ocasiões foram veiculadas imagens de projetos para a região pelo poder público: os ganhadores do 2 Prêmio Prestes Maia em 2006 e o projeto do escritório do Arq. Jaime Lerner em 2019. Atualmente se encontram em tramitação tanto o PIU Setor Central, que envolve a área do entorno do Minhocão quanto o PIU Parque Minhocão, que dispõe sobre o desenho do parque sobre o tabuleiro.

Concretamente, de todos os projetos de lei e planos realizados ao longo de 20 anos, os únicos que alteraram efetivamente a ocupação do espaço foram aqueles que trataram dos horários de fechamento para o tráfego de veículos motorizados, estendendo o horário nos dias úteis e incluindo às $24 \mathrm{~h}$ dos sábados (Lei $\mathrm{n}$. 16.833/2018), alterando os horários praticados desde a década de 1990. Sobre os planos, nenhum deles foi implementado de 


\begin{tabular}{|c|c|c|c|c|c|c|c|c|}
\hline \multicolumn{9}{|c|}{ NÃO PROPÕEM MUDANÇA DE USO } \\
\hline $\begin{array}{l}\text { PL 288/2014 | Lei } \\
16.525 / 2016\end{array}$ & 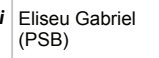 & $6 / 06 / 2014$ & & & & & & \\
\hline \multicolumn{9}{|c|}{ PRO-TRANSFORMAÇÃO } \\
\hline \multicolumn{3}{|c|}{ PRO-PARQUE } & \multicolumn{3}{|c|}{ NEUTRO } & \multicolumn{3}{|c|}{ PRO-DEMOLIÇÃO } \\
\hline PL 664/2005 & $\begin{array}{l}\text { Aurélio Nomura } \\
\text { (PV) }\end{array}$ & $18 / 10 / 2005$ & $\begin{array}{l}\text { 2o Prêmio } \\
\text { Prestes Maia }\end{array}$ & $\begin{array}{l}\text { Gilberto Kassab } \\
\text { (DEM) }\end{array}$ & $1 / 05 / 2006$ & $\begin{array}{l}\text { Operação Urbana } \\
\text { Lapa-Brás }\end{array}$ & $\begin{array}{l}\text { Gilberto Kassab } \\
\text { (DEM) }\end{array}$ & $15 / 05 / 2010$ \\
\hline $\begin{array}{l}\text { PL 10/2014 - Lei } \\
16.833 / 2018\end{array}$ & $\begin{array}{l}\text { Police Neto } \\
\text { (PSDB) + Nabil } \\
\text { Bonduki (PT) + } \\
\text { Outros }\end{array}$ & $5 / 02 / 2014$ & $\begin{array}{l}\text { Lei 16.050/2014 - } \\
\text { PDE }\end{array}$ & $\begin{array}{l}\text { Fernando Haddad } \\
\text { (PT) }\end{array}$ & $31 / 07 / 2014$ & PL 98/2018 & $\begin{array}{l}\text { Mlranda (PSB) + } \\
\text { Cristófaro (PSB) } \\
+ \text { Outros }\end{array}$ & $3 / 05 / 2018$ \\
\hline $\begin{array}{l}\text { Emenda } \\
2712 / 2014\end{array}$ & $\begin{array}{l}\text { Police Neto } \\
\text { (PSD) }\end{array}$ & $18 / 12 / 2014$ & PL 22/2015 & $\begin{array}{l}\text { Police Neto } \\
\text { (PSD) }\end{array}$ & $4 / 02 / 2015$ & PL 336/2019 & Cristófaro (PSB) & $28 / 05 / 2019$ \\
\hline PL 259/2016 & $\begin{array}{l}\text { Police Neto } \\
\text { (PSD) }\end{array}$ & $25 / 05 / 2015$ & & & & & & \\
\hline $\begin{array}{l}\text { PL 439/2015 - Lei } \\
\text { 16.397/2016 }\end{array}$ & $\begin{array}{l}\text { Police Neto } \\
\text { (PSD) }\end{array}$ & $28 / 08 / 2015$ & & & & & & \\
\hline $\begin{array}{l}\text { Projeto de Jaime } \\
\text { Lerner }\end{array}$ & $\begin{array}{l}\text { Bruno Covas } \\
\text { (PSDB) }\end{array}$ & $21 / 02 / 2019$ & & & & & & \\
\hline Relatório PIU & $\begin{array}{l}\text { Bruno Covas } \\
\text { (PSDB) }\end{array}$ & $15 / 01 / 2019$ & & & & & & \\
\hline
\end{tabular}

forma ampla e as transformações no espaço se deram por duas vias, pelas quais não podemos dizer que nem o parque nem a sua demolição estejam sendo realizados: a primeira foi a implementação da ciclovia sob o tabuleiro, que se realizou em contexto de implantação de uma extensa malha viária, e a segunda foi a instalação de jardins verticais, que tiveram que ser recentemente retirados pelo custo de manutenção.

Buscando ainda fazer um balanço da força destes projetos apresenta-se um gráfico (gráf. 2.4.1) da plataforma Google Trends que mostra o número de vezes (em porcentagem) que um certo termo foi procurado no buscador online Google. No eixo y, o valor máximo (100\%), se refere à data que apresentou o maior número de interações; o restante dos valores é apresentado em porcentagem em relação a este valor máximo. No gráfico mapeamos os termos "parque minhocão" (em vermelho) e "desmonte minhocão" (em azul). De início percebemos que a capilarização do termo "parque" é infinitamente maior sobre o "desmonte", tornando a última desprezível.
Tabela. 2.4.1

Leis, planos e projetos para o Minhocão. 


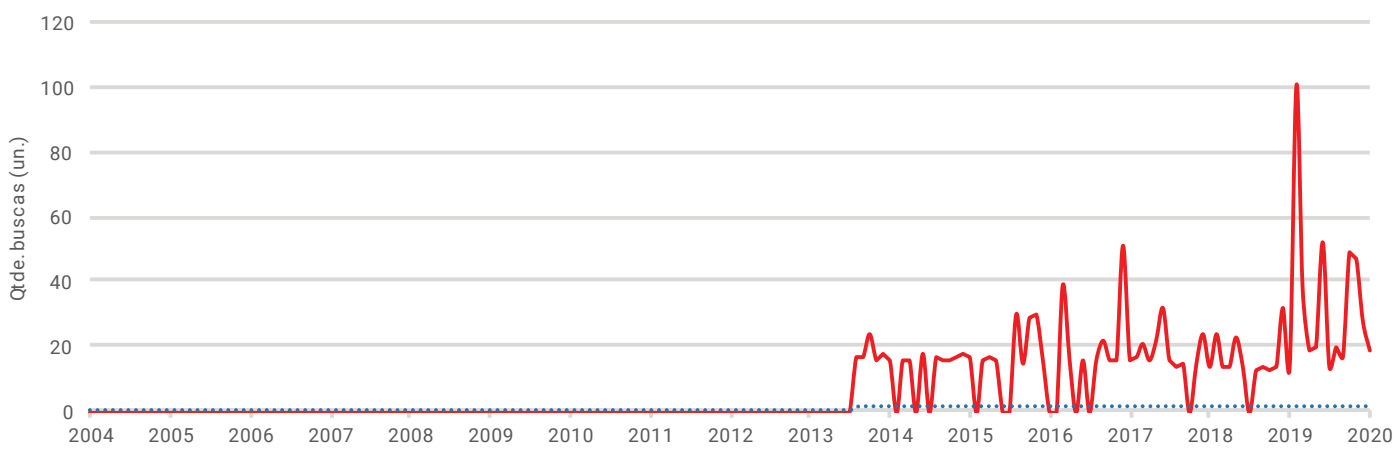

Gráf. 2.4.1

Evolução das buscas dos termos "Parque Minhocão" e "Desmonte Minhocão" na plataforma Google Trends. Google Trends, 2020.

\section{- "Parque Minhocão" \\ ... "Desmonte Minhocão"}

\section{Gráf. 2.4.2}

Interações a partir da notícia publicada na Revista Veja São Paulo. Monitor do Debate Político do Meio Digital, 2020.

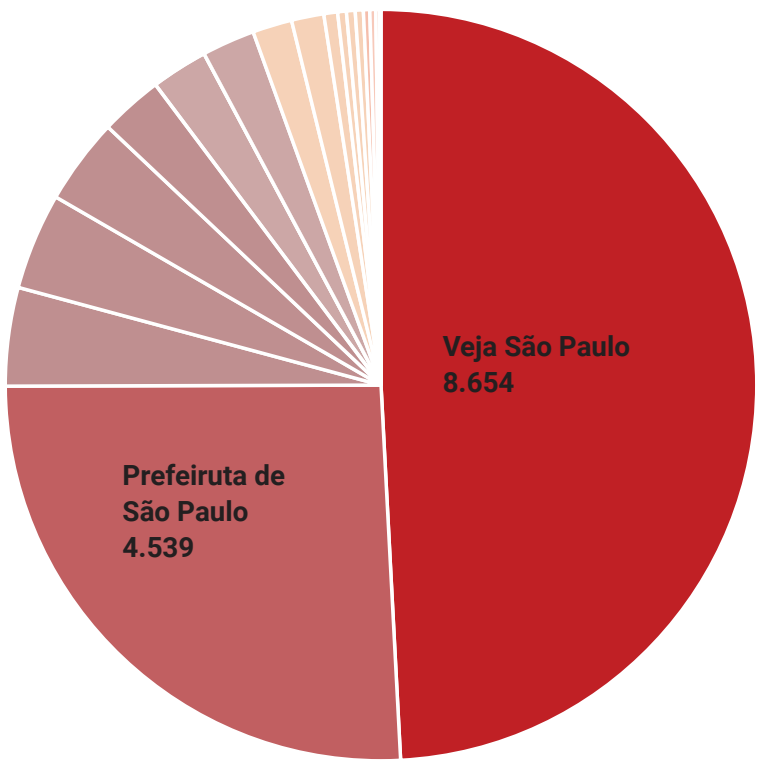

Verificamos aqui que o termo "Parque Minhocão" ganha relevância a partir de 2014, justamente associado às discussões do PDE e ao consequente surgimento das organizações da sociedade civil. Porém vemos que o ápice da linha azul não se encontra em 2014 e nem mesmo em 2018, quando foi promulgada a lei que criou o Parque Minhocão (Lei n. 16.833/2018), mas em 2019 quando a prefeitura veiculou a capa da Veja com o projeto 


\section{Prefeitura de Săo Paulo \\ $1 \mathrm{~h} \cdot \mathrm{O}$}

Prefeitura anuncia a criaçăo do Parque Minhocło. Confira a matéria da Veja Săo Paulo: https://abr.ai/2TOLQ5t - com Secretaria Municipal de Urbanismo e Licenciamento - SMUL

Descriçāo da imagem \#PraCegoVer: a foto mostra uma ilustração de como ficará o Parque Minhocăo.

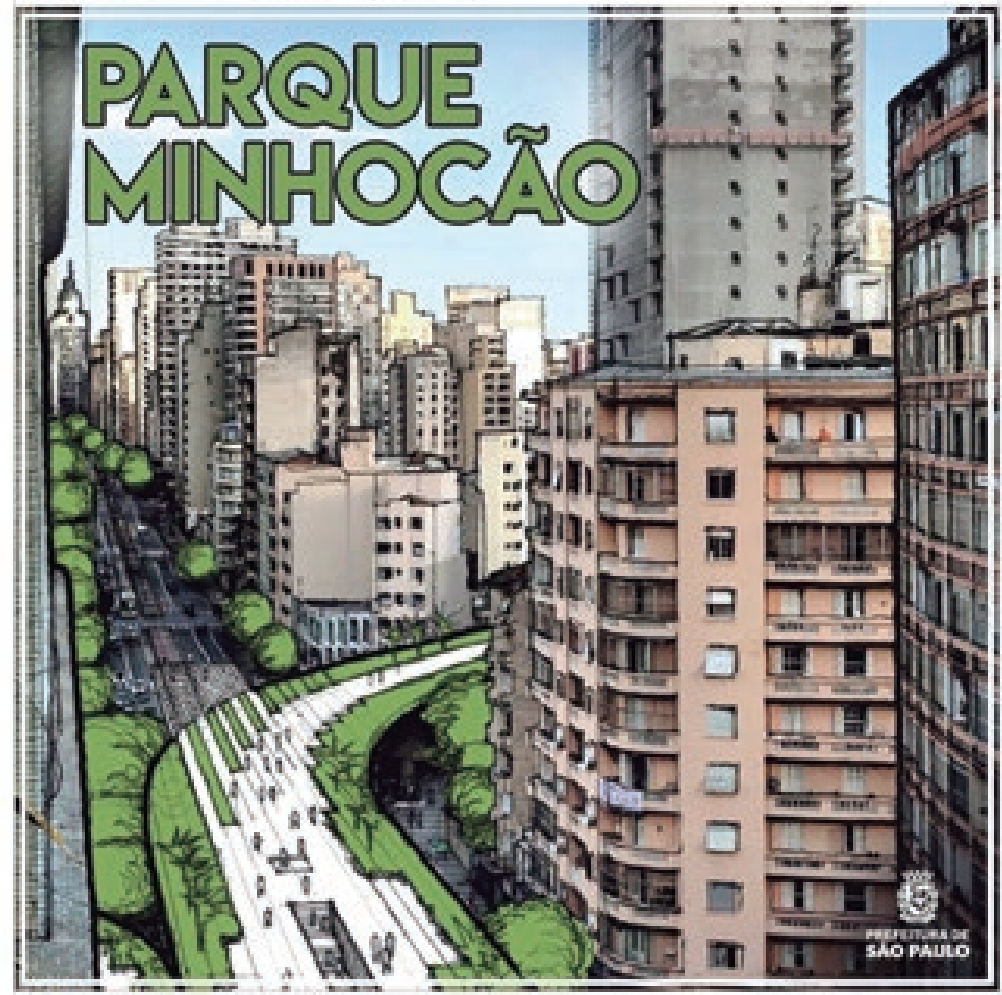

$09 \% 650$

140 comentários 167 compartilhamentos

Curtir

Comentar

A Compartilhar

do Arq. Jaime Lerner. Conforme dissemos antes, o projeto do escritório Jaime Lerner foi publicado na página do Facebook da Prefeitura de São Paulo (fig. 2.4.1) dois anos depois da apresentação realizada sobre o mesmo à prefeitura, à qual tivemos acesso por meio da LAI. 
O gráfico atesta o poder das imagens tendo em vista que a data com maior interação se refere, praticamente, ao único momento que se veiculou uma imagem sobre a transformação do Elevado. Para avançarmos nesta discussão mapeamos o número de repostagens geradas em torno desta notícia publicada inicialmente na revista Veja São Paulo (gráf. 2.4.2). Verificamos que o maior número de interações foi promovido pela somatória de 3 postagens, publicadas em dois dias seguido, no Facebook da própria Veja (8.654 interações). A segunda maior postagem em número de interações foi gerada pela prefeitura de São Paulo (4.539). E na sequência aparecem outros agentes menores entre os quais podemos citar em ordem decrescente de interações: Diogo da Luz - NOVO (745); agenda cultural SP (732); Parque Ibirapuera Conservação (652); Secretaria Municipal de Desenvolvimento Urbano - SMDU (475); Viva Mooca (430); Exame (401); Police Neto (299); etc.

Se claramente, dois grupos se enfrentam nesta disputa: de um lado aqueles que querem a construção de um Parque Elevado, representados pela Associação Parque Minhocão, de outro aqueles que querem a sua demolição, representados pelo Movimento Desmonte Minhocão, o gráfico mostra que a ideia de parque canaliza maior interesse que o desmonte. Ambos grupos representados na Câmara por um pool de vereadores diversos. Os gráficos mostram como um debate nesta esfera, aparentemente polarizada e circunscrita, ganha capilaridade em outros âmbitos, em grupos não vinculados exatamente com a pauta do Minhocão mas em temas tangenciais à mesma. $\mathrm{O}$ debate se afunila rumo à produção de um consenso, ambos grupos acabam reforçando a necessária transformação do espaço, que implica pelo seu avesso na capitalização da transformação do espaço pela sua (re)comercialização.

As imagens resultantes deste debate, que foram ganhando capas de jornais e revistas, modificaram lentamente os signos que impregnaram historicamente essa emblemática estrutura. Signos que se vinculam tanto a ideias presentes nos novos Planos Diretores, quanto os paradigmas contemporâneos de urbanidade. Símbolos por um lado da recuperação do espaço público, escu- 
recido na construção do Elevado, por outro de novas formas de acumulação capitalista, associadas aos processos de valorização imobiliária por meio da capitalização das transformações futuras pela da propriedade.

Para elucidar o que estamos querendo dizer, trazemos aqui duas imagens que nos ajudam a discutir aspectos dessa nova urbanidade. A primeira imagem (fig. 2.4.2) se trata de um registro fotográfico que mostra o Minhocão - naquele momento intitulado Elevado Costa e Silva - produto de um governo autoritário: vemos carros e empenas de edifícios cobertas de propagandas, a maioria delas anunciam peças de carros. Estas propagandas se posicionam ao longo do percurso e anunciam, por um lado produtos - o automóvel e suas peças - que se realizam na fábrica distante daquele lugar por onde eles circulam, e por outro lado um paradigma urbano, um modo de viver e de construir cidades, pautado no desenho urbano de matriz rodoviarista voltado para o fluxo rápido dos automóveis. O fluxo é privilegiado sobre a permanência, nas margens os imóveis perderam valor devido à degradação ambiental que o descaso com o espaço urbano trouxe, quiçá se encontram vazios, quiçá ocupados irregularmente. As propagandas também falam sobre um momento da acumulação capitalista pautado na valorização na esfera da produção, fruto do trabalho na fábrica e o lucro dele extraído.

A segunda imagem retrata (fig. 2.4.3) um anúncio de carros da marca Chevrolet, por meio de uma imagem produzida pelo escritório de arquitetura franco-brasileiro Triptyque. Nesta propaganda de carros, não vemos carros, e sim o Minhocão convertido em parque. Agora ele se chama "Parque MInhocão", as empenas dos edifícios vizinhos exibem jardins verticais e nas coberturas foram instaladas turbinas eólicas para a produção de energia limpa. Aqui a propaganda é o retrato do próprio urbano, do local do consumo onde a sociedade se reproduz. Ela também diz sobre um novo modo de viver e produzir cidades, em aparente maior harmonia com o meio ambiente: no produto que a propaganda anuncia não aparece o degradante chão de fábrica inimigo da natureza, mas retrata pessoas aproveitando o tempo livre no parque ou se deslocando de bicicleta. Esta imagem 


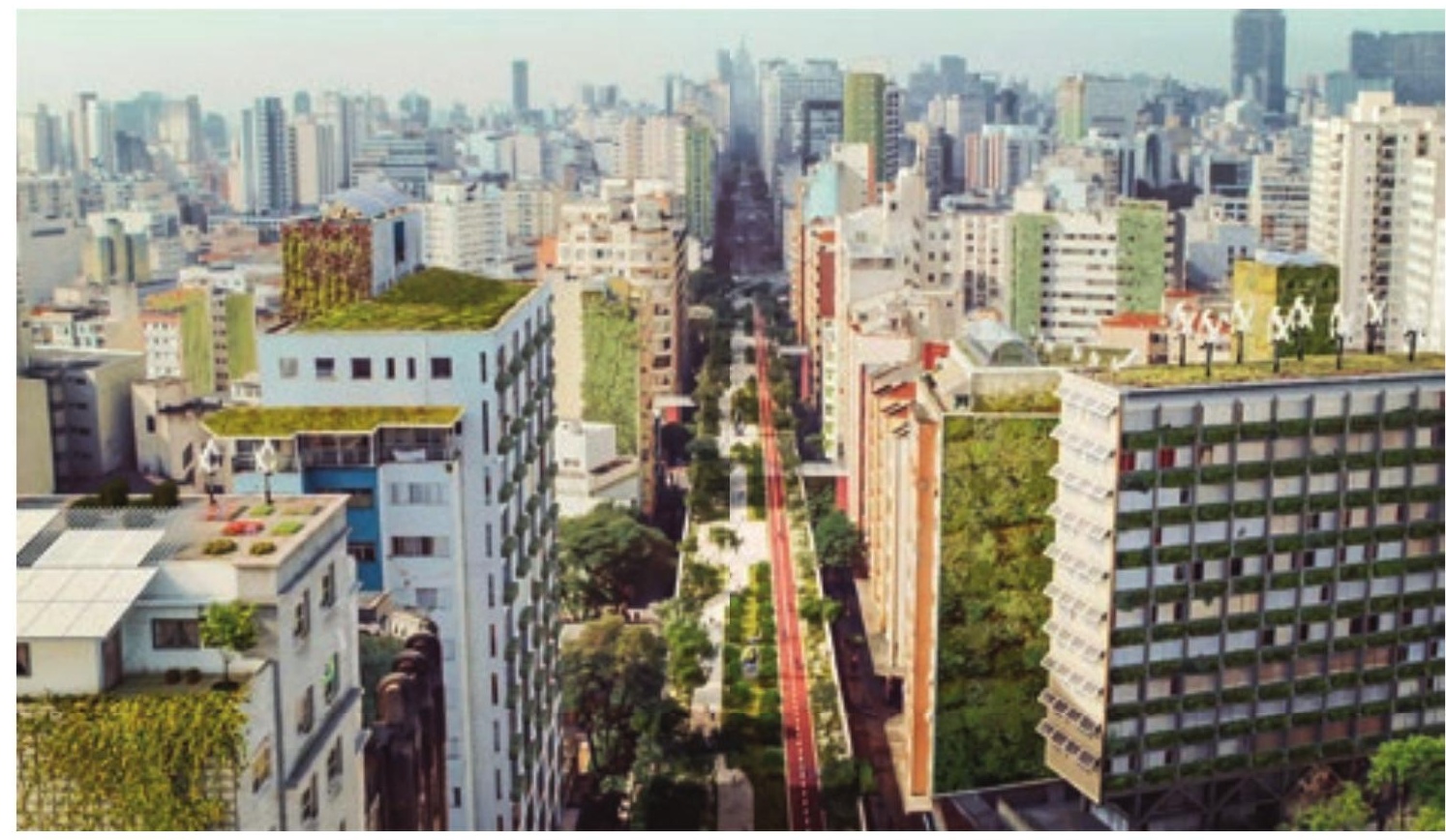

uma reorganização completa da produção subordinada aos centros de informação e decisão.

O urbanismo encobre essa gigantesca operação. Ele dissimula seus traços fundamentais, seu sentido e finalidade. Ele oculta, sob uma aparência positiva, humanista, tecnológica, a estratégia capitalista: o domínio do espaço, a luta Fig. 2.4.3 Campanha criada pela WMcCann para a Chevrolet, com colaboração da PBA Cinema e da Triptyque Architecture. Veja SP, 2019. contra a queda tendencial do lucro médio etc. (Lefebvre, 1999, pp. 140-141).

Apesar de que pouco tenha se alterado concretamente na estrutura do Elevado, nas suas margens o espaço é apropriado, comprado e vendido. Cabe no próximo capítulo analisar as transformações concretas nas suas margens. Talvez indique uma nova forma de planejar cidades, na qual cabe ao urbanismo a veiculação de imagens carregadas de signos, o poder público pouco realiza, mas o capitalismo ganha um novo fôlego na apropriação do espaço capitalizado mediado pelas imagens que o ente público anuncia. Imagens que produzem um outro espaço social virtual e que contribuem na construção deste consenso cívico, conforme aponta Lefebvre (1999): 
O pensamento dos tecnocratas oscila entre a representação de um espaço vazio, quase geométrico, tão somente ocupado pelos conceitos, pelas lógicas e estratégias no nível racional mais elevado, e a representação de um espaço finalmente pleno, ocupado pelos resultados dessas lógicas e estratégias. Eles não percebem, em primeiro lugar, que todo espaço é produto, e, em seguida, que esse produto não resulta do pensamento conceitual, o qual não é, imediatamente, força produtiva. $\mathrm{O}$ espaço, considerado como produto, resulta das relações de produção a cargo do grupo atuante. Os urbanistas parecem ignorar ou desconhecer que eles próprios figuram nas relações de produção, que cumprem ordens. Executam quando acreditam comandar o espaço. (Lefebvre, 1999, p. 139).

As imagens, construídas por meio destas leis, planos e projetos, mesmo que difusas se constituem como impulsos virtuais apropriáveis por interesses ávidos por capitalizar as transformações em suas propriedades. A construção de um consenso cívico, obedecendo os espaços democráticos de construção coletiva e os pactos urbanos, deve ser entendido nos termos que Harvey aponta: "a produção orquestrada de uma imagem urbana também pode, se bem-sucedida, ajudar a criar solidariedade social, orgulho cívico e lealdade ao lugar" (Harvey, 2005, p. 185). Porém associado aos interesses monopolistas, esta imagem virtual poderá se transformar em ideologia e/ou hegemonia. Hegemonia concebida "como direção e domínio e, portanto, como conquista, através da persuasão, do consenso, mas também como força para reprimir as classes adversárias" (Gruppi, 1978, apud Brandão, 2012, p. 85). Ideologia enquanto discurso institucional que justifica ou legitima as instituições existentes (Lefebvre, 1999, p. 99), aqui em prol da transformação do espaço que é, conforme vimos, crescimento. Ou "positivismo urbanístico que aceita, que ratifica os fatos consumados, que constata isto ou aquilo sem questionar, interditando, inclusive, o questionamento" (Lefebvre,1999, p. 63). 


\title{
capítulo 3
}

\section{Produção do espaço e renovação da propriedade imobiliária no entorno do Minhocão: a produção concreta da cidade}

\begin{abstract}
As desigualdades urbanas não são um dado e nem a construção da cidade um mero subproduto ou reflexo da maneira com que ocorre a industrialização e a distribuição da riqueza. Embora seja certo que a industrialização faça crescer o urbano, é a urbanização que leva ao aprofundamento das desigualdades na cidade. Isso significa que a nossa hipótese é que essas desigualdades urbanas têm mais a ver com o processo social de construção imobiliária da cidade (o setor) do que com a industrialização em geral. Por isso, a compreensão das formas de produção do espaço urbano, num determinado lugar e num determinado momento, é decisiva para se compreender as desigualdades urbanas (Pereira, 2005, p. 6).
\end{abstract}

Neste terceiro e último capítulo, nos debruçamos sobres as transformações concretas do espaço nas margens do Elevado. Discutimos a produção imobiliária para mercado, como este espaço está sendo gradualmente transformado e as disputas que 
se travam neste contexto. Elencamos como formas de ocupação popular encontram novos agentes nesse processo de modo a compreender como as injustiças sociais são reproduzidas na produção do espaço.

No primeiro item, buscamos enquadrar por um lado em termos teóricos e de forma ampla a especificidade da mercadoria imobiliária, a sua precificação e, consequentemente, como se realiza a sua valorização ${ }^{62}$. Por outro, analisamos as transformações nos marcos que regulam a atividade imobiliária no Brasil e de que forma eles impactaram nas transformações do espaço nas metrópoles do País, tratamos especificamente de algumas mudanças na produção de São Paulo. Discutimos brevemente como a própria produção do espaço no sistema capitalista exacerba as contradições e os conflitos deste modo de produção.

No segundo item, nos debruçamos nos lançamentos imobiliários de edifícios residenciais no entorno do Minhocão ao mesmo tempo em que buscamos continuamente relacionar essa produção às transformações do desenvolvimento urbano no resto da cidade com foco nos bairros que o Elevado atravessa. Como recorte territorial para esta análise, nos valemos da região demarcada no zoneamento da cidade (Lei ${ }^{0} 16.402 / 2016$ ) como Zona Eixo de Estruturação da Transformação Metropolitana (ZEM) em torno do Minhocão.

Finalmente, no último item, analisamos as transformações do espaço para além dos novos lançamentos imobiliários residenciais e os limites que a valorização do setor encontra aqui, buscando complexificar a análise de como se dá a disputa pelo espaço. Discutimos em primeiro lugar em termos quantitativos as mudanças na forma como a propriedade está sendo consumida. Na sequência, discutimos o perfil das pessoas que moram no entorno, buscando elucidar no nível imediato qual é a população que mais sofre com as transformações e quais são os limites para a ampliação dos ganhos do setor. Esclarecemos em termos qua-

62. Nos referimos aqui ao termo 'valorização' na sua determinação mais vulgar, que trata da elevação do preço. 
litativos como este espaço de reprodução das camadas populares está sendo gradualmente transformado e por fim nos debruçamos sobre uma nova tipologia de estabelecimentos comerciais que têm se reproduzido com intensidade, sobretudo na região da Vila Buarque, e passa a constituir um importante agente a disputar o espaço. 


\section{Notas sobre a produção do espaço no Brasil do século XXI: novos marcos regulatórios para a produção imobiliária}

No intuito de nos aproximarmos da produção concreta do espaço, neste primeiro item do último capítulo, analisamos a especificidade da mercadoria imobiliária e sua precificação e o movimento amplo de mudanças nos axiomas da acumulação capitalista. Destacamos a centralidade que a renda imobiliária assume nos centros urbanos na determinação do preço do imobiliário, a valorização por meio da capitalização e sua consequente articulação com os novos negócios financeiros.

$\mathrm{Na}$ complexidade que envolve este ramo da produção capitalista, discutimos o processo (paradoxal) de homogeneização (das relações mercantis) e de diferenciação espacial pelo qual a produção imobiliária movimenta o espaço urbano continuamente. Analisamos de forma ampla como isto acontece em áreas tidas como desvalorizadas das cidades, nos aproximando de processos de "renovação urbana". Aqui nos valemos do conceito de rent gap para articular, ainda de forma abstrata, as questões acima enunciados a processos de espoliação urbana.

Posteriormente, analisamos as transformações nos marcos regulatórios da atividade imobiliária no Brasil e nas novas estruturas de financiamento imobiliário associadas à criação do Sistema Financeiro Imobiliário (SFI). Detemo-nos especificamente sobre os novos incentivos à produção voltada para o mercado popular e como este quadro tem influenciado a produção imobiliária nos centros urbanos desvalorizados. Rapidamente, analisaremos alguns grandes movimentos do mercado imobiliário na cidade de São Paulo para contextualizar certas questões particulares no entorno do Minhocão. 


\section{A especificidade na mercadoria imobiliária: uma aproximação da propriedade aos negócios financeiros}

O espaço é, de início, um sustentáculo para qualquer atividade humana que, privatizado e comercializado, assume um preço. Como sustentáculo para qualquer atividade, seja ela mercantil ou não, ele possui um valor de uso, fundamental para a produção capitalista e a reprodução da sociedade. Como mercadoria (comercializável), assume um valor de troca. Entendemos que o preço da terra é um elemento abstrato, determinado socialmente e em constante movimento, e isso se deve em parte ao fato da terra (em estado bruto) não ser fruto do trabalho humano, mas possuir um preço. Seu valor não repousa sobre a quantidade de trabalho necessário para sua produção como na maioria das outras mercadorias. Esse fato distancia de início o preço no imobiliário do seu custo de produção.

A mercadoria, resultado da produção imobiliária, difere das outras mercadorias pela conjugação de outras características. A primeira, e principal delas, como seu nome diz, é a mercadoria ser imóvel, ou seja, estar fixa a uma localização. O ramo da produção imobiliária se ocupa, de forma ampla, da construção e comercialização de espaços (bens imóveis), das mais variadas escalas e qualidades, que necessariamente devem ocupar uma localização, um endereço, e a ela estão eternamente associados. Como consequência dessa condição primeira, temos que este ramo da produção capitalista não consegue produzir duas mercadorias iguais, uma edificação existe associada a um determinado lugar e por ela monopolizar o direito de uso desse lugar, pelo instituto da propriedade privada, nenhuma outra edificação pode ser idêntica a ela. Paralelamente, estas mercadorias constituem um conjunto, o meio ambiente espacial, que define uma localização pela sua relatividade, sua posição em relação a todas as outras. O pagamento de um preço pelo acesso ao espaço determina o acesso dos agentes econômicos às vantagens desta localização e excluem os outros do acesso a esse mesmo espaço por meio do caráter privado da propriedade. Estes fatos (por sua 
singularidade e relatividade) dificultam a criação de um mercado de imóveis capaz de regular os preços desse ramo da atividade econômica, de tal forma que a determinação dos valores de troca é assunto de grandes controvérsias e disputas:

\footnotetext{
Por causa dessa heterogeneidade, não há um 'preço da terra' ou 'preço de moradia' perceptível; esses termos têm significado apenas como números-índice, e não existe um consenso sobre o modo de calcular esses números-índice (...) 'Quem obtém o quể no mercado da terra urbana é mais uma coisa prática com que devemos nos preocupar do que o que é o preço da moradia ou da terra, embora a distribuição da terra e de edifícios seja feita essencialmente por meio do preço. (Smith, 1970, p. 164 apud Gottdiener, 2016, p. 180).
}

O preço pago pelos bens imóveis, sejam eles terra desenvolvida ou não desenvolvida, é antes de mais nada um preço pago pelo acesso a esta propriedade que define o pagamento de rendas. Devemos destacar aqui, porém, que existem duas formas pelas quais a terra é explorada na produção capitalista: "por um lado, a exploração da terra para fins de reprodução ou de extração; por outro, o espaço necessário como um elemento de toda produção e de toda atividade humana" (Marx, 1986, p. 238). Estes dois papéis definem dois tipos de renda que se imbricam na determinação do preço dos bens imóveis, mas que analiticamente diferenciamos: a renda fundiária e a renda imobiliária. Pereira detalha essa diferenciação da seguinte maneira:

A renda absoluta, como renda fundiária, origina-se da mais-valia extraída no processo de trabalho da construção, não importando aí o tipo do edifício ou o uso a que se destina, porém sendo fundamental a forma de produção do edifício. Por outro lado, a renda imobiliária provém do caráter de monopólio de privatização do espaço, que, pela necessidade de se pagar o acesso à localização, torna possível a formação de um preço no mercado imobiliário que sobe até os limites permitidos pelas condições de pagamento na disputa pela utilização do espaço, independentemente da forma de produção do edifício (Pereira, 1988 , p. 121). 
Em ambas formas de explorar a terra, a apropriação das rendas é um processo externo ao processo de produção, seja do próprio espaço seja das outras atividades que se realizam no espaço construído, que cobra parte da mais-valia gerada nele pela concessão de uso de uma propriedade. Na metrópole de São Paulo, assim como em outras metrópoles do mundo, a escassez de terra a ser explorada e a disputa pelas localizações, dada a intensa atividade econômica sobreelevam, a cada momento, o preço da terra. Pela centralidade das rendas e o caráter monopolístico da produção imobiliária, a intensa atividade imobiliária não se traduz em um rebaixamento no preço dos bens imóveis, ao contrário, o preço "sobe até os limites permitidos pelas condições de pagamento" (Pereira, 1988, p. 21).

No gráfico a seguir (gráf. 3.1.1.), verificamos a evolução de preços na cidade de São Paulo. Por um lado podemos ver em momentos de intensa atividade imobiliária (2008-2014) a elevação vertiginosa dos preços dos bens imóveis (seja para a compra, seja para a locação). Por outo, em momentos de recessão verificamos o sentido inverso não se realiza (2014-2016), pelo contrário: os preços se mantêm constantes em patamar elevado mesmo quando há baixa demanda. Ainda nele podemos constatar como o preço de compra se sobre eleva de forma exponencial sobre o preço de locação, o que ilumina a forma como o preço no imobiliário se constitui enquanto uma capitalização das rendas futuras (uma antecipação). Podemos verificar neste gráfico uma elevação primeira dos preços de locação (rendas) que na sequência se reflete na elevação de preços de compra. Em uma metrópole como São Paulo o preço da terra incorpora a elevação das rendas que se multiplicam pela intensificação da produção, ou em outras palavras, do adensamento construtivo. Na medida que numa mesma propriedade são produzidos um número elevado de unidades, a elevação do valor de locação de cada uma delas eleva de forma exponencial o preço da terra.

Por esta ótica observamos o lado perverso do projeto de cidade compacta: a construção em densidade não se rebate em um rebaixamento dos preços da terra, pelo contrário seu preço se eleva de forma vertiginosa. Levando em consideração que este 


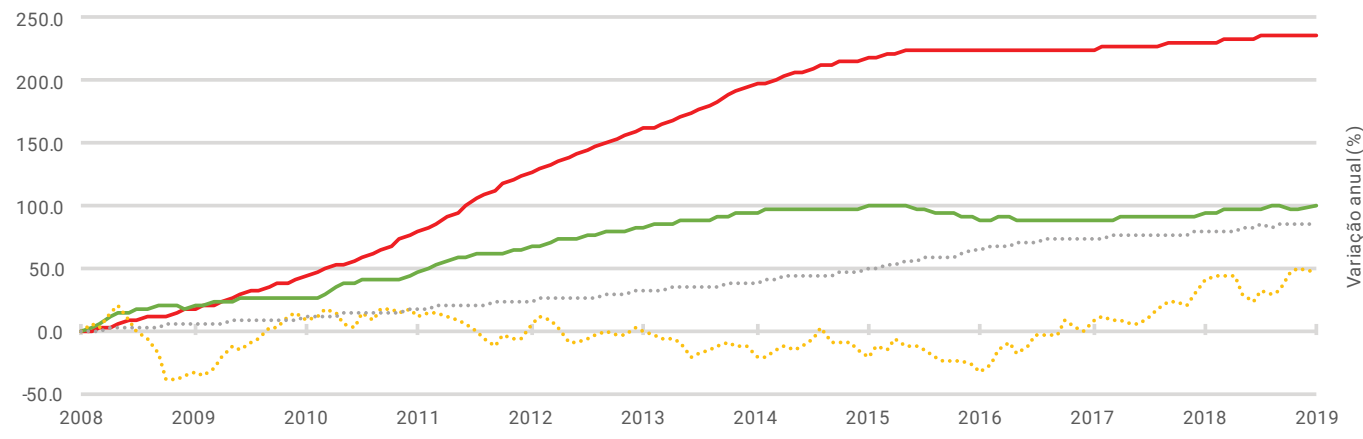

Gráf. 3.1.1

Evolução dos preços de locação e compra MSP em porcentagem. Fipezap, 2020.

- Índice FIPEZAP venda

- Índice FIPEZAP locação

... IBOVESPA

... IPCA gradiente de preços da terra determina "essencialmente" a distribuição dos usos da cidade, determinando quem acessa ela pelo poder de compra, este modelo de cidade reforça por meio da própria urbanização formas de espoliação urbana. Constitui-se assim o processo pelo qual os trabalhadores insolventes, população em situação de maior vulnerabilidade, é obrigada a viver em situações precárias e/ou irregulares. A partir de um levantamento realizado por Otero (2012) (fig. 3.1.1) sobre o preço de venda de terrenos vagos verificamos como na metrópole de São Paulo os lugares no quais se produziu de maneira mais intensa são aqueles que apresentam preços da terra mais elevados ou vice versa. A proeminente diferença entre o preço no centro expandido, principalmente no vetor sudoeste, e na maior parte do resto da metrópole, determina por esta via o caráter desigual da disputa pelo acesso à terra.

O manual básico de Real Estate, "Real Estate Development: principles and process", esclarece que a prática mais comum de precificação de uma propriedade nos Estados Unidos é a capitalização do fluxo de rendas ${ }^{63}$. De acordo com o que enunciamos acima, o preço no imobiliário é um valor pago para se ter acesso ao bem imóvel e a sua quantificação está relacionada à previsão do fluxo de rendas (fundiárias ou imobiliárias) que por direito adquirido

63. "The most common form of property valuation in the united states is capitalization of a property's income stream" (Miles; Netherton; Schmitz, 2015, p. 190). 


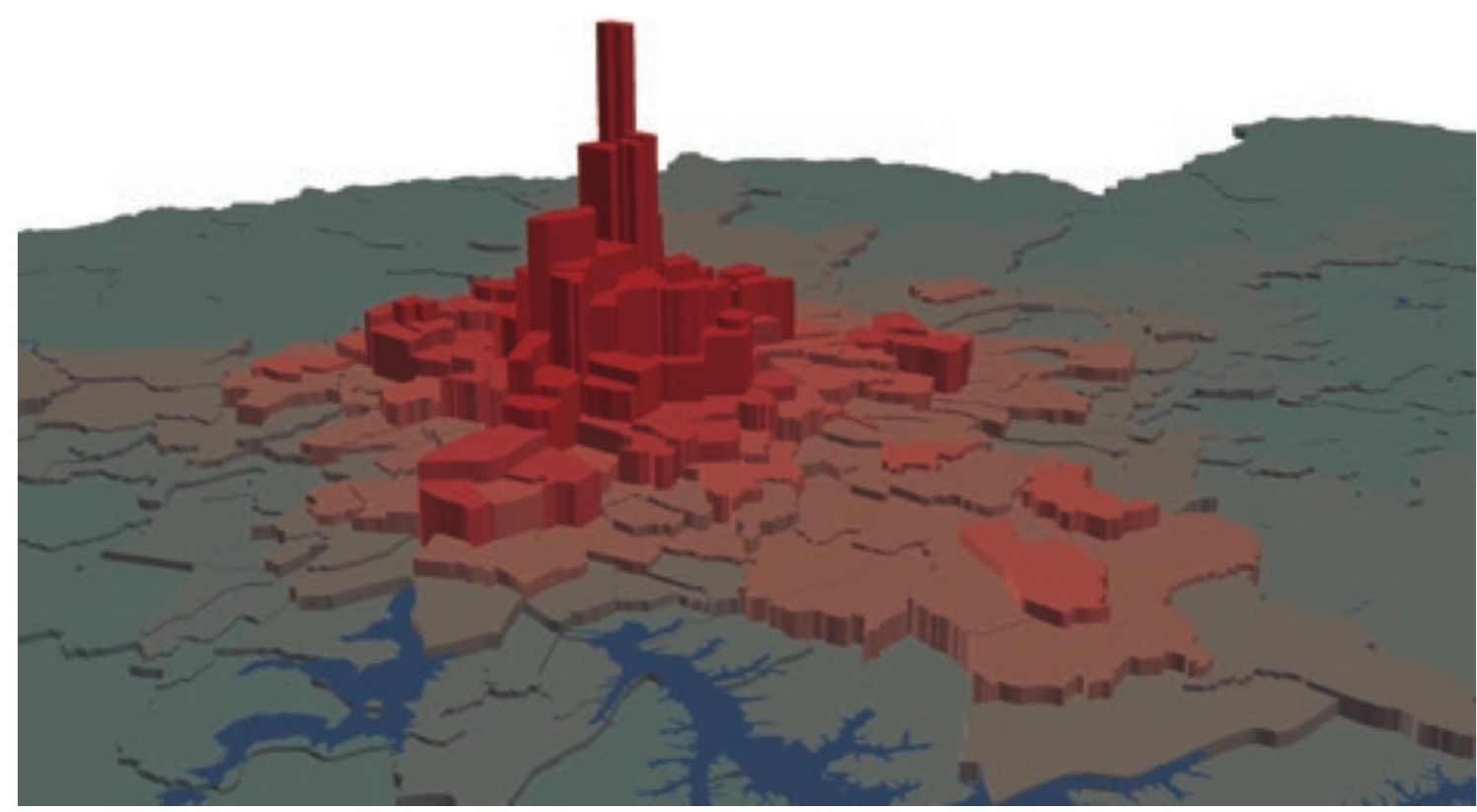

poderão ser percebidas, uma vez concedida a propriedade. Disso decorre que o preço no imobiliário se trata de uma quantidade de dinheiro adiantada a fim de se apropriar um fluxo de rendas futuro, em outras palavras o preço no imobiliário é uma capitalização. Para nosso trabalho, o conceito de capitalização é central para entendermos tanto a centralidade que as rendas assumem na precificação dos bens imóveis quanto os axiomas que regem a sua valorização. Conforme Harvey aponta:

A teoria da renda fundiária resolve o problema de como a terra, que não é um produto do trabalho humano, pode ter um preço e ser trocada como uma mercadoria. A renda fundiária, capitalizada como o juro sobre algum capital imaginário, constitui o 'valor' da terra. O que é comprado e vendido não é a terra, mas o direito à renda fundiária produzido por ela. (...) O comprador adquire um direito sobre as receitas futuras antecipadas, um direito sobre os frutos futuro do trabalho. $\mathrm{O}$ direito à terra se torna, em resumo, uma forma de capital fictício (Harvey, 2013, p. 471).

Fig. 3.1.1 Gradiente de preços de terrenos vazios ofertados na RMSP. Otero, 2012. 
Nos aprofundando na ideia de capital fictício, Chesnais aponta que ele "designa todos os ativos financeiros cujo valor repousa sobre a capitalização de um fluxo de rendas futuras, que não têm nenhuma contrapartida no capital industrial efetivo" (Chesnais, 2006, p. 41 apud Marques; Nakatani, 2008, pp. 13-14). Por se tratar de uma reivindicação sobre uma renda futura, hipotética e incerta, a sua constituição foge da materialidade do capital produtivo e se conforma como um capital fictício, justamente porque sua constituição se afasta do trabalho (Lencioni, 2015, p. 151). Deste ponto de vista, a propriedade imobiliária se aproxima do capital portador de juros como um instrumento que reivindica (por lei) um valor gerado na produção, mas que se localiza fora dela.

A partir da crise internacional da década de $1970^{64}$, a relativa estagnação do setor produtivo impulsionou globalmente o crescimento do capital financeiro na procura de uma contínua valorização, possível num contexto de mercados globalizados e desregulamentação das economias nacionais. Neste sentido, Lencioni (2015) recuperando Aglietta (1998) argumenta que estaríamos migrando de um regime de acumulação fordista (realizado na esfera da produção) para um regime de acumulação patrimonial (realizado na esfera da circulação), em que a propriedade opera um papel fundamental.

Neste novo regime de acumulação, os proprietários de títulos, agentes situados em posição de exterioridade à produção, detêm o direito de uma parte dos rendimentos e consequentemente impõem uma lógica de valorização imediata e continuada com base na definição de metas e projeções. A propriedade de imóveis, de títulos financeiros ou mesmo intelectual ganha centralidade justamente por ser ela (a propriedade) que encerra o direito à percepção de rendas:

Foi Aglietta (1998) quem chamou atenção para a formação de um novo regime, que se impôs ao fordismo. A essa nova fase ele denominou de regime de acumulação patrimonial. Essa

64. Data relacionada à saída dos Estados Unidos do tratado de Bretton Woods. 
denominação é muito pertinente, uma vez que a propriedade patrimonial encerra (inclui) o direito à renda, quer seja essa renda relativa a imóveis, quer seja em relação às aplicações do capital-dinheiro em atividades financeiras. (...) Chesnais, falando da atual lógica da propriedade patrimonial, diz que a “finalidade dela não é nem o consumo nem a criação de riqueza que aumentem a capacidade de produção, mas o 'rendimento'. (Chesnais, 2005, p. 50). Torna-se compreensível, então, que nesse novo regime - regime de acumulação patrimonial - em que à valorização (ao aumento de valor do capital pelo trabalho) se agrega de maneira pródiga a capitalização. E, com ela a especulação se amplia. A especulação, vale lembrar, se projeta no futuro antevendo o quanto pode render a propriedade de um imóvel, de uma ação ou de um título da dívida pública, dentre a propriedade de tantos papéis e expedientes, apostando nas oscilações do mercado e na maximizaçãoo dos rendimentos. (Lencioni, 2015, p. 151)

Nesse sentido, Paulani (2016) entende que o capitalismo contemporâneo contêm um "fortíssimo traço rentista", no qual o poder das classes burguesas estaria crescentemente articulado em torno da apropriação de rendas. Ou seja, aquilo que em um primeiro momento se colocaria como uma competição intersetorial pela apropriação de mais valor gerado na produção e, que constitui um entrave para o avanço da produção, passa a funcionar cada vez mais como um único movimento de acumulação e concentração de capital. Este traço fictício ganha, então, relevância na determinação do preço da mercadoria imobiliária, que se distancia do custo de produção, conforme aponta Petrella:

\footnotetext{
O preço do produto imobiliário é, portanto, uma construção social, cada vez mais em função de incorporar sua diferenciação e menos em função da atividade produtiva em particular. Deste modo, o 'preço da construção' emerge como a 'construção do preço', que incorpora a arbitrariedade (o capital fictício como árbitro) do descolamento entre valor de construção e preço do construído. O preço decorre da capitalização de rendas que são pressupostas e de valores de uso que respondem (ou não) a necessidades e desejos socialmente reconhecidos. (Petrella, 2017, p. 252).
} 
Outras características desta mercadoria, além das já citadas, merecem ainda destaque e se conjugam no espaço de tal forma que reforçam a sua especificidade: o longo período de produção e o longo período de circulação (Topalov, 1974 apud Pereira e Rufino, 2011). A produção de bens imóveis é uma atividade cujo ciclo de produção dura, entre aquisição de terreno e entrega do produto acabado, um longo período, muitas vezes mais de um ano. Assim como o longo ciclo de produção, a sua circulação no mercado, a sua depreciação, também têm duração bem acima da média. A necessidade de um grande montante de capital para aceder à terra, assim como a capacidade de parcelar o alto valor deste produto pelo seu longo período de circulação, já faziam da produção imobiliária um local historicamente propício de aproximação da produção ao capital de empréstimo (financeiro). Contudo, o desenho deste novo arranjo de negócios rentistas aproxima a mercadoria imobiliária de um próprio ativo financeiro.

A produção do espaço é pautada, então, pelo movimento espiralar de valorização de capital localizado fora da produção, privilegiando os negócios que garantem as maiores rendas e, consequentemente, resultando em um escalonamento vertiginoso dos preços da terra. "A projeção de ganhos financeiros (capital fictício) impulsiona a elevação da renda imobiliária e amplia a histórica relevância do setor" (Rufino, 2012, p. 216). "Esta sobrevida ao imobiliário, imediato, corporifica a sobrevida ao financeiro, global, cuja acumulação real combinada com a fictícia encontra na produção do espaço um meio de absorção e capitalização do excedente" (Petrella, 2017, p. 21). A aproximação entre o setor imobiliário e o setor financeiro se intensifica à luz de um cenário de estagnação dos setores produtivos e consequente rebaixamento das taxas de lucro. Nesse sentido, Lefebvre afirma:

Na medida em que o circuito principal, o da produção industrial corrente dos bens 'mobiliários', arrefece seu impulso, os capitais serão investidos no segundo setor, o imobiliário. Pode até acontecer que a especulação fundiária se transforme na fonte principal, o lugar quase exclusivo de 'formação de capital', isto é, de realização da mais-valia. Enquanto a parte da 
mais-valia global formada e realizada na indústria decresce, aumenta a parte de mais-valia formada e realizada na especulação e pela construção imobiliária. O segundo circuito suplanta o principal. De contingente, torna-se essencial. (Lefebvre, 1999, p. 144).

O que estamos querendo destacar é que os ganhos de produtividade do trabalho têm seus efeitos alterados face ao significado da propriedade na produção imobiliária. Conforme vimos, diferentemente de outros ramos da produção capitalista, o valor de troca (preço) dos bens imóveis, principalmente os urbanos, não guardam aqui relação direta com o seu custo de produção. A concorrência imobiliária transita, por isso, muito mais na figura do proprietário que na de produtor, quem procura obter vantagens na venda do produto em detrimento dos ganhos de produtividade do trabalho na construção (Pereira, 1988, p. 106). Consequentemente, a diferenciação em detrimento da padronização é central para entender a produção do espaço; a heterogeneidade está no cerne na produção imobiliária de tal forma que a produção imobiliária é diferenciação na busca por retornos extraordinários (rent gap).

Devemos reforçar, por outro lado, apoiados em Brandão (2012), que a expansão das relações de produção capitalistas necessárias para a reprodução do sistema e para a generalização da forma mercadoria forçam o espaço a um processo contínuo de homogeneização. O movimento do capital pressupõe a "busca de construção de um espaço uno de acumulação e à destruição de quaisquer barreiras espaciais e temporais que possa gerar atritos e fricções a seu movimento geral" (Brandão, 2012, p. 73). O que não quer dizer, como o próprio autor levanta na sequência, que este processo resulte em uma estrutura "niveladora de desigualdades", pelo contrário "na verdade, esse processo homogeneizador (de relações mercantis) cria e recria estruturas heterogêneas e desigualdades no seu movimento" (Brandão, 2012, p. 73). Processo associado, também, ao que Marx chama de "tendência à equalização da taxa de lucro", que no atual estágio de desregulamentação das economias nacionais e "fluxo livre de capital que rende juros (aumentado pela existência das formas fictícias 
do capital)" (Harvey, 2013, p. 357) dá novo impulso à destruição das inúmeras barreiras espaciais.

Este movimento paradoxal de homogeneização e diferenciação é fundamental para entender a produção do espaço no sistema capitalista, como um movimento que ao mesmo tempo que se diferencia destrói as barreiras que entravam a sua reprodução em um processo de homogeneização. Em outras palavras, Rufino coloca:

A contínua necessidade de ampliação da valorização do capital através da produção imobiliária, imposta pelo capital centralizado e seus vínculos com o capital financeiro, determina transformações nas relações espaciais, seja na escala do empreendimento, através de mudanças em suas características físicas e simbólicas, seja na escala da cidade, através da diversificação de estratégias de apropriação do espaço, que de uma maneira geral implica no reforço da valorização imobiliária em diferentes intensidades pelos diversos espaços da metrópole. (Rufino, 2012, p. 205).

Ao longo do tempo, os termos "renovação urbana", "reabilitação urbana" e "requalificação urbana" têm sido mobilizados para falar dos projetos urbanos para as áreas centrais "degradadas" da cidade, empreendidos pelo poder público. Por vezes, tem se formalizado a distinção entre eles para explicitar peculiaridades de diferentes processos e por outras tem se deixado de lado as especificidades, escolhendo apenas um dos termos para designar de forma ampla projetos de transformação urbana em áreas de urbanização consolidada.

Nobre (2009) trata da distinção entre "renovação urbana" e "reabilitação urbana"; descreve o primeiro como um processo de renovação do ambiente construído, implicando na substituição de uma forma antiga por uma nova, e o segundo implicando apenas em projetos pontuais de melhorias sem alterar significativamente a forma anterior. Por outro lado, Petrella (2017) conceitua "renovação urbana" como um processo mais abrangente de diferenciação espacial: 
O fenômeno da Renovação Urbana é uma reestruturação espacial que se realiza em determinadas situações, pontuais ou especiais da metrópole. Opera por uma finalidade ou estratégia específica. Implica em um processo de produção, um produto e um uso também específicos. Nesta especialização, a espacialização se diferencia. A Renovação se realiza ao imbricar incorporação imobiliária, predominantemente de caráter privado, e infraestrutura, predominantemente de caráter público. (...) Estas operações se utilizam de estratégias políticas, econômicas, jurídicas não usuais ao conjunto da metrópole e nesta configuração espacial-especial inclui o uso e abuso de 'arquiteturas e urbanismos' também especiais, objetos únicos que aguçam o caráter espetacular de tais intervenções. (Petrella, 2017, p. 18).

\begin{abstract}
Abramo (2012), por sua vez, conceitua estas inovações no espaço como um reordenamento espacial que articula uma nova espacialidade urbana a um novo produto. Ele entende que a mobilização da demanda para uma nova região precisa necessariamente de uma transformação da "convenção urbana" ou "externalidade de vizinhança", de tal forma que só existiria inovação espacial se existir essa combinação entre mobilização da demanda e um rearranjo da "convenção urbana". O autor defende que a forma de realizar essa associação é a mesma que utilizam os setores de bens de consumo duradouros: promover continuamente a diferenciação dos produtos, que envolve a oferta de um produto diferente numa nova espacialidade. Em um sentido semelhante, Harvey atrela a ideia de inovação à valorização de regiões urbanas degradadas:
\end{abstract}

\footnotetext{
A valorização de regiões urbanas degradadas, a inovação cultural e a melhoria física do ambiente urbano, atrações para consumo e entretenimento se tornaram facetas de parecer um lugar inovador, estimulante, criativo e seguro para se viver e visitar, para divertir-se e consumir. Os festivais e os eventos culturais também se tornaram foco das atividades de investimento: 'as artes criam um clima de otimismo'. O espetáculo e a exibição se transformam em símbolos de uma comunidade dinâmica. (Harvey, 2005, p. 176).
} 
Smith (2007) associa os processos de renovação urbana e desenvolvimento comercial a novas fronteiras de lucratividade, processos motivados por uma pluralidade de agentes econômicos, mais ou menos organizados, que desencadeiam mudanças na estrutura dos preços da terra. Smith desenvolve aqui o conceito de rent gap para explicar o processo de elevação de preços em lugares onde o mercado tira proveito de áreas desvalorizadas, nas quais o baixo preço pago pelo acesso à terra é multiplicado na extração de lucros extraordinários, associados a um novo "maior e melhor uso", que capitaliza uma transformação futura do espaço (Smith, 2007). É, portanto, na antecipação de uma condição futura favorável para a comercialização de espaço em locais desvalorizados e na capacidade dos agentes de prever ou motivar esta transformação, que emergem vantagens comerciais extraordinárias. Neste sentido, a construção simbólica de áreas "degradadas" torna-se "lucrativa", conforme aponta Petrella:

\footnotetext{
Neste sentido, a construção da (des)valorização imobiliária, apreciação e depreciação, se configura como uma fronteira de expansão da lucratividade e rentabilidade garantidas pela renovação urbana: fronteira infernal de acumulação de capital realizada sobre 'espaços críticos', degradados ou inadequados aos padrões contemporâneos de produção e de consumo. Uma 'crise urbana' identificada a um determinado limite espacial, a um perímetro determinado, e a acumulação se expande a partir da reconversão destes espaços através de demolições de edifícios, remembramento de lotes, construção de novas infraestruturas e edificações, associada à proposição de novos usos e usuários (limites de pagamento) (Petrella, 2017, p. 264).
}

Espaços estes geralmente destinados em certa quantidade à reprodução das camadas populares que tendem a ser substituídos por novos usos em prol da rentabilidade. A síntese desse movimento, conforme aponta Smith, é a gentrification como "uma fronteira na qual fortunas são criadas" (Smith, 2007, p. 29). Para entendermos esse processo, devemos recuperar aqui a centralidade que o capital fictício, associado à capitalização de um fluxo rendas futuro, assume na precificação do imobiliário. Sobre a relação entre gentrification, renovação urbana e diferenciação Smith (2007) escreve: 
A gentrificação, a renovação urbana e o mais amplo e complexo processo de reestruturação urbana são todos parte da diferenciação do espaço geográfico na escala urbana; e, embora estes processos tenham sua origem em um período anterior à atual crise econômica mundial, sua função hoje é reservar uma pequena parte do substrato geográfico para um futuro período de expansão. (Smith, 2007, p. 18).

A atividade imobiliária, ao mesmo tempo que se manifesta no espaço materialmente, alavanca processos sociais (complexos) que carregam as contradições do desenvolvimento capitalista. Como explica Pereira:

As desigualdades urbanas não são um dado e nem a construção da cidade um mero subproduto ou reflexo da maneira com que ocorre a industrialização e a distribuição da riqueza. Embora seja certo que a industrialização faça crescer o urbano, é a urbanização que leva ao aprofundamento das desigualdades na cidade. Isso significa que a nossa hipótese é que essas desigualdades urbanas têm mais a ver com o processo social de construção imobiliária da cidade (o setor) do que com a industrialização em geral. Por isso, a compreensão das formas de produção do espaço urbano, num determinado lugar e num determinado momento, é decisiva para se compreender as desigualdades urbanas (Pereira, 2005, p. 6).

Para este trabalho, analisamos, portanto, a centralidade que a rendas imobiliárias assumem tanto na precificação da mercadoria imobiliária quanto na reestruturação do sistema capitalista e na constituição de um nova plataforma de valorização do capital. Ainda discutimos como a diferenciação é fundante para entendermos este ramo de atividades, associada ao instituto da propriedade privada e como ele transforma o espaço por meio da diferenciação. Finalmente, entendemos processos de renovação urbana mais associados à própria atividade imobiliária "especialização onde a espacialização se diferencia" (Petrella, 2017, p. 18) do que aos planos, independizando o conceito da necessidade de um projeto urbano. 
Na sequência, discutimos como este movimento, colocado aqui de forma ampla, ganha contornos institucionais nos novos marcos regulatórios da atividade imobiliária no Brasil.

\section{Crédito e novos marcos regulatórios para a produção imobiliária no Brasil}

A estruturação de um novo sistema financeiro não é uma invenção do governo Fernando Henrique Cardoso ${ }^{65}$, contudo é especificamente neste governo que tal política começa a assumir contornos mais claros ${ }^{66}$. O mandato FHC (1995-2002) consolidou as bases do que se entende como um novo momento do financiamento imobiliário no Brasil dentro do contexto de desregulação da economia, inflação controlada e taxa de juros decrescente do final da década de 1990. A paulatina construção de um novo marco regulatório para o financiamento e a produção imobiliária visou a criação de um ambiente seguro para a penetração das finanças e culminou na instituição do Sistema Financeiro Imobiliário (SFI) em 1997 (Lei no 9.514/1997) ${ }^{67}$.

O SFI foi o início de uma série de leis e normas que buscam articular negócios imobiliários ávidos de crédito ao capital financeiro na procura por rentabilidade. Ele vem de encontro à gradual transição mundial das formas de acumulação que discutimos anteriormente: a relativa estagnação do setor produtivo

65. Conforme visto no primeiro capítulo, trata-se de um processo que tem suas raízes na década de 1970.

66. "A emergência com Collor e a consolidação com FHC das reformas liberalizantes possuem, grosso modo, as seguintes características: a abertura externa da economia; a desregulação (acentuada no mercado financeiro); privatização de empresas estatais federais e, mais recentemente, de empresas e bancos estaduais; e as sucessivas tentativas de reduzir as 'Redes de Proteção Social', notadamente na área trabalhista e da Previdência" (Affonso, 2000, p. 127).

67. Antes dele, devemos destacar a instituição dos Fundo de Investimento Imobiliário (FII's) em 1993 (Lei n 8.668/1993), que permitiram "reunir recursos para investimentos, sem fragmentar a propriedade do imóvel" e portanto "atrair investidores que não tinham necessariamente interesse em utilizar o imóvel (Fix, 2011, p. 126). 
impulsionou o crescimento do capital financeiro na procura de uma contínua valorização, viável em um contexto de mercados globalizados e liberalizados por meio da desregulamentação das economias nacionais.

Ao longo da década de 1980 e, principalmente, nos anos 1990, as políticas de austeridade fiscal pautadas na redução da máquina estatal, disseminadas pelo mundo ocidental - sobretudo no continente americano - e sustentadas ideologicamente pelo controle da inflação, diminuíram o papel do Estado como agente garantidor de direitos e de amparo às necessidades básicas de reprodução do trabalhador. Associadas a elas, ganhou crédito a liberalização da economia como solução para captação de recursos e retomada dos investimentos, o que permitiu uma crescente penetração das finanças nas atividades econômicas e sociais. Neste sentido, conforme aponta Lapavitsas (2009), "os trabalhadores foram crescentemente arrastados para a esfera das finanças privadas a fim de satisfazer necessidades básicas, incluindo moradia, consumo, educação, saúde e provisões para a terceira idade" (Lapavitsas, 2009, p. 146 apud Sanfelici, 2013, p. 31).

Apesar de se tratar de um marco regulador, o SFI busca dar condições e segurança para atrair o capital pulverizado que circula livremente pelo globo em busca de taxas de rentabilidade extraordinárias em regiões justamente flexibilizadas. Consequentemente, aproximam-se os negócios imobiliários a outros negócios financeiros no globo como plataformas de reprodução do capital. Como explica Royer (2009):

O modelo contido no SFI não tem dependência de funding direto ou de direcionamento obrigatório, como o $\mathrm{SFH}$, e procura captar fundos junto ao mercado de capitais. O SFI prevê, em seu modelo teórico, que o coração do sistema seja a captação de recursos em um mercado secundário de títulos de créditos e recebíveis imobiliários. Por isso conta com instrumentos financeiros destinados a fazer essa ponte entre o mercado de capitas e o mercado imobiliário (Royer, 2009, p. 100). 
O desenho básico deste novo arranjo de negócios rentista se dá pela aquisição e, consequentemente, propriedade de títulos que "possuem como lastro os ativos que foram securitizados, tendo suas receitas baseadas no fluxo de caixa proveniente, seja de juros sobre o empréstimo, seja de outros recebíveis" (Vedrossi, 2002, p. 21 apud Royer, 2009, p. 108). Arranjo que permite decompor grandes ativos imobiliários fixos à terra em um enxame de títulos mobiliários de grande liquidez, barateando os custos do financiamento, multiplicando os agentes financiadores e, em teoria, independizando o financiamento da ação estatal (em um contexto de diminuição ideológica da máquina pública ${ }^{68}$. Neste sentido, foram instituídos no Brasil, o Certificado de Recebíveis Imobiliários (CRI); a Letra do Crédito Imobiliário (LCI); a Cédula de Crédito Imobiliário (CCI); no caso dos CRIs, instituído na mesma que lei que o SFI.

O domínio das finanças associado à renda tende a transformar atividades com fluxo de retorno contínuo em uma atividade-alvo para sua transformação em "título passível de ser negociado em mercados secundários e de ser, portanto, objeto de especulação" (Sanfelici, 2013, p. 34). Os detentores desses títulos, por sua vez, tornam-se os proprietários de uma parcela do negócio, situados em posição de exterioridade à produção, que impõem uma lógica de valorização imediata e continuada a partir da definição de metas e projeções. Consequentemente, as rendas imobiliárias, principalmente aquelas que movimentam um grande volume de capital, como os aluguéis corporativos e comerciais, assim como os próprios créditos imobiliários que resultam no pagamento mensal de prestações se tornam alvo potencial dos agentes financeiros, cabendo ao Estado dar segurança para essas transações.

Conforme analisa Royer (2009), ao longo do começo da década de 2000 e para além do SFI, novas leis, normas e medidas provisórias foram promulgadas buscando tornar o ambiente dos negócios imobiliários um ambiente mais seguro para os investimentos. Medidas que além de criar uma alíquota única de

68. No caso do Brasil isso não se verificou de início tendo em vista o direcionamento de recursos do SBPE e FGTS para a aquisição de CRI's para impulsionar a disseminação do instrumento (Royer, 2009, pp .123-124). 
7\% para a incorporação, instaurar a previdência privada como garantia nos financiamentos e isentar dos impostos de renda as pessoas físicas adquirentes de cotas de fundos imobiliários (Royer, 2009, p. 120), instauraram certos instrumentos que aqui damos atenção especial: a Alienação Fiduciária, o Patrimônio de Afetação e do Valor do Incontroverso.

O Patrimônio de Afetação e o Valor do Incontroverso foram instituidos junto com as LCI e CCI na Lei de Patrimônio e Afetação (Lei n.10.931/2004). O primeiro contribuiu ao segregar as contas dos empreendimentos das contas da empresa promotora, "evitando que o comprador de um determinado empreendimento venha a ser prejudicado pela falência total da empresa ${ }^{69}$. Já o Valor de Incontroverso ajudou por garantir o pagamento das prestações de um comprador que esteja questionando em juízo o valor do contrato assinado com o promotor, suspendendo o pagamento apenas daquilo que "está sendo questionado judicialmente e não em relação a todo o contrato" (Royer, 2009, p. 118).

Dadas as condições básicas de segurança jurídica, estabilidade econômica e com a economia retomando seu ritmo de crescimento, algumas incorporadoras e empresas da construção em geral focaram na estratégia internacionalmente difundida, mas nacionalmente nova para este segmento, de abertura de capital na bolsa de valores. Estratégia esta que se tornou uma promessa de rápida captura de grande volume de recursos a baixos custos financeiros para financiar seu crescimento. Sanfelici (2012) descreve este novo momento da produção imobiliária no Brasil da seguinte forma:

Em primeiro lugar, é preciso frisar que a integração das
incorporadoras imobiliárias à dinâmica da bolsa de valores
no Brasil é um fenômeno novo e, especialmente para esse
setor, produziu um ambiente de negócios inteiramente dife-
renciado. Primeiramente, porque esse setor se caracterizou,

69. Foi o caso da empresa Encol, que quebrou nos anos 1990 e deixou muitos empreendimentos sem finalização mesmo com apartamentos já vendidos (Royer, 2009, p. 118) 
historicamente, por um predomínio da empresa familiar, que administrava um número de canteiros compatível com um quadro gerencial reduzido. A maior parte das empresas familiares, mesmo de grande porte, raramente investia em mercados para além de sua região de origem, o que muda substancialmente com a entrada de grandes players capitalizados pela bolsa de valores. Em segundo lugar, esse momento é diferenciado porque, para além de um crescimento do volume de investimentos e do raio de operação das empresas, induziu a mudanças qualitativas na forma de conduzir os negócios imobiliários, decorrentes, primordialmente, da presença do investidor financeiro (Sanfelici, 2012, p. 36).

Esta nova forma de capitalização via capital excedente, que circulava livremente pelo globo resultou, a partir dos anos 2000 , no crescimento acelerado de algumas empresas do setor da construção que, para garantir o retorno dos acionistas e dos detentores de títulos, reorientaram seus planos de negócios e horizontes de atuação. A captação de grandes volumes de capital no cenário globalizado permitiu que a barreira colocada pelo acesso à propriedade fundiária fosse superada. A dificuldade de aceder à terra, um empecilho histórico determinante à expansão do mercado imobiliário, foi superada por empresas capitalizadas que, como primeira ação pós-abertura de capitais, ampliaram seu estoque de terras, processo que culminou na elevação de preços da terra, que vimos no gráfico anterior (gráf. 3.1.1.).

No mesmo sentido, novas estratégias foram desenhadas para intensificar e multiplicar o resultado dos investimentos: por um lado, diversificar as regiões de atuação, por outro focar em negócios que envolvessem um grande volume de capitais, tanto no investimento quanto no retorno, o que resultou na construção de empreendimentos de grande porte em áreas pouco exploradas do mercado imobiliário. Conforme aponta Rufino: 


\begin{abstract}
O recente aumento dos fluxos de capitais para a produção imobiliária nos grandes centros urbanos favoreceu a ampliação do porte dos empreendimentos imobiliários e a diversificação de sua localização por diversos espaços da metrópole, desencadeando processos de fragmentação e iluminando os limites e insuficiência da interpretação com base na dicotomia centro-periferia (Rufino, 2013, p. 14).
\end{abstract}

A diversificação do pool de investimentos em diferentes áreas do território nacional foi uma das estratégias adotadas pelas empresas da construção para expandir seu mercado e ocupar novos nichos. A cartela de investimentos destas empresas combinou lançamentos de mais e menos riscos em múltiplos mercados, aproximando a forma de atuação daquela adotada por acionistas e pelos fundos de investimento: englobar uma diversidade de ativos para garantir um retorno médio de acordo às expectativas dos credores. Se as estratégias empresariais empurraram os novos lançamentos para lugares pouco explorados anteriormente, o marketing imobiliário teve que transformar essas áreas desvalorizados do ponto de vista do preço da terra em novas localidades valorizadas.

No sentido da expansão dos nichos de mercado, mais recentemente (2009) devemos destacar o lançamento do programa federal de financiamento habitacional Minha Casa Minha Vida (MCMV). Se este programa, inicialmente, surgiu como medida anticíclica para conter a crise mundial, desencadeada pelos subprimes americanos em $2008^{70}$, logo se constituiu de forma perene como um importante instrumento de financiamento do setor. Com recursos do Orçamento Geral da União (OGU) e do FGTS, que já vinham sendo novamente mobilizados para o financiamento habitacional ${ }^{71}$, o Fundo de Arrendamento

70. Crise que abalou a confiança do mercado justamente naquilo que constituía a própria base do novo funding imobiliário pós SFI.

71. "O vertiginoso aumento da produção imobiliária alcançado no início de 2008 só pode ser entendido à luz do forte movimento de recuperação dos financiamentos no âmbito do SFH. (...) Aqui, mais uma vez, o capital desvalorizado, direcionado pelo Estado à produção imobiliária, assume um papel decisivo na ampliação dos ganhos do setor, viabilizando a aliança entre o capital financeiro e o setor imobiliário" (Rufino, 2012, p. 58). 
Residencial (FAR) foi, então, mobilizado para a liberação de crédito subsidiado voltado à construção privada de unidades habitacionais para o mercado popular. Como explica Fix (2011), "o volume de subsídios que o pacote oferece na sua primeira edição, 34 bilhões de reais, era de fato inédito na história do país: nem mesmo o BNH dirigiu tantos recursos para baixa renda numa mesma operação" (Fix, 2011, p. 140). O resultado foi uma produção espraiada por todo o território nacional cuja importância e magnitude "alçou a habitação a problema nacional" (Fix, 2011, p. 141), e que respondeu "a um só tempo, a problemas de acumulação, por meio da injeção de recursos no circuito imobiliário, a construção de edificações e construção pesada, indústria de materiais e componentes, mercado de terras e legitimação, ao responder à pressão das lutas sociais do ponto de vista da demanda por habitação e por emprego" (Fix, 2011, p. 141).

Neste contexto, o "segmento econômico", que já vinha conquistando a atenção das empresas da construção dentro do quadro de diversificação de mercados, é elevado a outro patamar. Com o aumento da capacidade de compra das camadas populares no governo Lula (2003-2010), associado a políticas de valorização do salário-mínimo, muitas empresas da construção, algumas delas com capital aberto, expandiram a sua atuação em direção a este "novo" segmento. Essas empresas passaram a adquirir outras menores, já com experiência no ramo, ou criaram novas empresas, voltadas especificamente a esse segmento, garantindo parte da mais-valia gerada nas operações subsidiadas com o capital desvalorizado proveniente deste programa. Vale reforçar que a viabilização desses empreendimentos para as camadas às quais pretende atender resultou numa corrida por terras baratas e consequente construção de unidades habitacionais distantes dos centro de emprego das metrópoles.

Os institutos aqui discutidos recaem de forma particular nas áreas centrais das cidades: por um lado, como local abandonado pela atividade imobiliária (portanto "desvalorizado"), nicho de mercado a ser potencialmente explorado em um contexto de expansão do setor. Por outro, locais de intensa circulação de pes- 
soas e bens, providos de infraestrutura e portanto "valorizados ${ }^{72}$ à espera de um bom marketing imobiliário para a realização do rent gap. Sobre a área central de São Paulo e os novos programas de incentivo à produção de habitação social, Shimbo escreve:

\footnotetext{
$\mathrm{Na}$ área central da cidade de São Paulo, além de apresentar políticas e programas específicos para a sua requalificação, repercutiu também o processo nacional de aquecimento do mercado imobiliário, em especial, os lançamentos residenciais pertencentes ao 'segmento econômico' que compreende os imóveis residenciais com valores de até $\mathrm{R} \$ 200.000,00$ (em reais de dezembro 2010, ou aproximadamente, cem mil dólares), destinados às famílias com renda mensal entre três e dez salários-mínimos, ou seja, aos setores de renda média e média baixa. No Brasil, esse segmento ganhou expressividade, sobretudo, a partir de 2006, quando uma injeção de recursos públicos e privados alavancou a produção de moradias pelo mercado (Shimbo, 2013, p. 217).
}

Conforme comentamos no capítulo anterior, nestes processos há uma reiterada construção de significados que buscam descrever uma certa área como "degradada" para justificar a necessidade de uma renovação urbana. Entende-se que a renovação urbana envolve a procura por lucros extraordinários na produção imobiliária e para tal mobilizam imagens internacionais "bem-sucedidas", além de novos edifícios culturais e espaços públicos de lazer.

Buscamos até aqui descrever como o novo marco regulatório dos negócios imobiliários, associados ao SFI e a programas de incentivo à construção regulam novas formas de produzir o espaço na metrópole, até atingir as áreas ditas "degradadas" da cidade. A transformação do Minhocão em parque urbano mobiliza intensamente a opinião pública: de um lado, carrega símbolos de recuperação do espaço público, praças e largos perdidos na construção da via expressa, por outro simboliza a nova

72. Aqui no sentido da quantidade de trabalho social plasmado na produção desta localidade. 
acumulação capitalista, associada aos processos de (re)valorização imobiliária por meio da capitalização das transformações futuras. Cabe, nos próximos itens, tentar elucidar as formas concretas como o espaço vem sendo transformado, consumido e apropriado. 


\section{2}

\section{A produção imobiliária para mercado no entorno do Minhocão}

Analisaremos aqui os lançamentos residenciais no entorno do Minhocão com base nos dados da Empresa Brasileira de Estudos de Patrimônio (Embraesp), que inclui os lançamentos realizados entre 1985 e 2018. Selecionamos aqueles empreendimentos lançados dentro da Zona Eixo de Estruturação da Transformação Metropolitana (ZEM) no entorno imediato do Minhocão, zona destinada no Zoneamento "a promover usos residenciais e não residenciais com densidades demográficas e construtivas altas" com "coeficiente de aproveitamento máximo igual a 4 e sem limite de gabarito". Importante esclarecer que na bases de dados da Embraesp a divisão territorial se dá por "Zonas de Valor"73, divisão que usaremos aqui quando analisamos os dados desta empresa.

Observamos nesta região (gráf. 3.2.1) um total de 44 lançamentos residenciais realizados com relativa regularidade ao longo do período analisado (1985-2018). Empreendimentos pertencentes a três Zonas de Valor que logo usaremos para realizar algumas comparações: Barra Funda, Santa Cecília e Centro ${ }^{74}$. Se dividirmos este período (1985-2018) em 2 partes iguais de 17 anos cada, um prévio ao PDE de 2002 (1985-2001) e outro posterior

73. "Zonas de Valor" é uma divisão territorial adotada pela Embraesp e divulgada nas suas planilhas que supostamente visa a ajustar o desenho dos bairros à dinâmica imobiliária. Não tivemos acesso para este trabalho aos critérios utilizados pela empresa para tais redesenhos, porém podemos afirmar que se aproximam muito dos distritos.

74. A Zona de Valor Centro engloba aqui, aproximadamente, os distritos de Sé e República. 

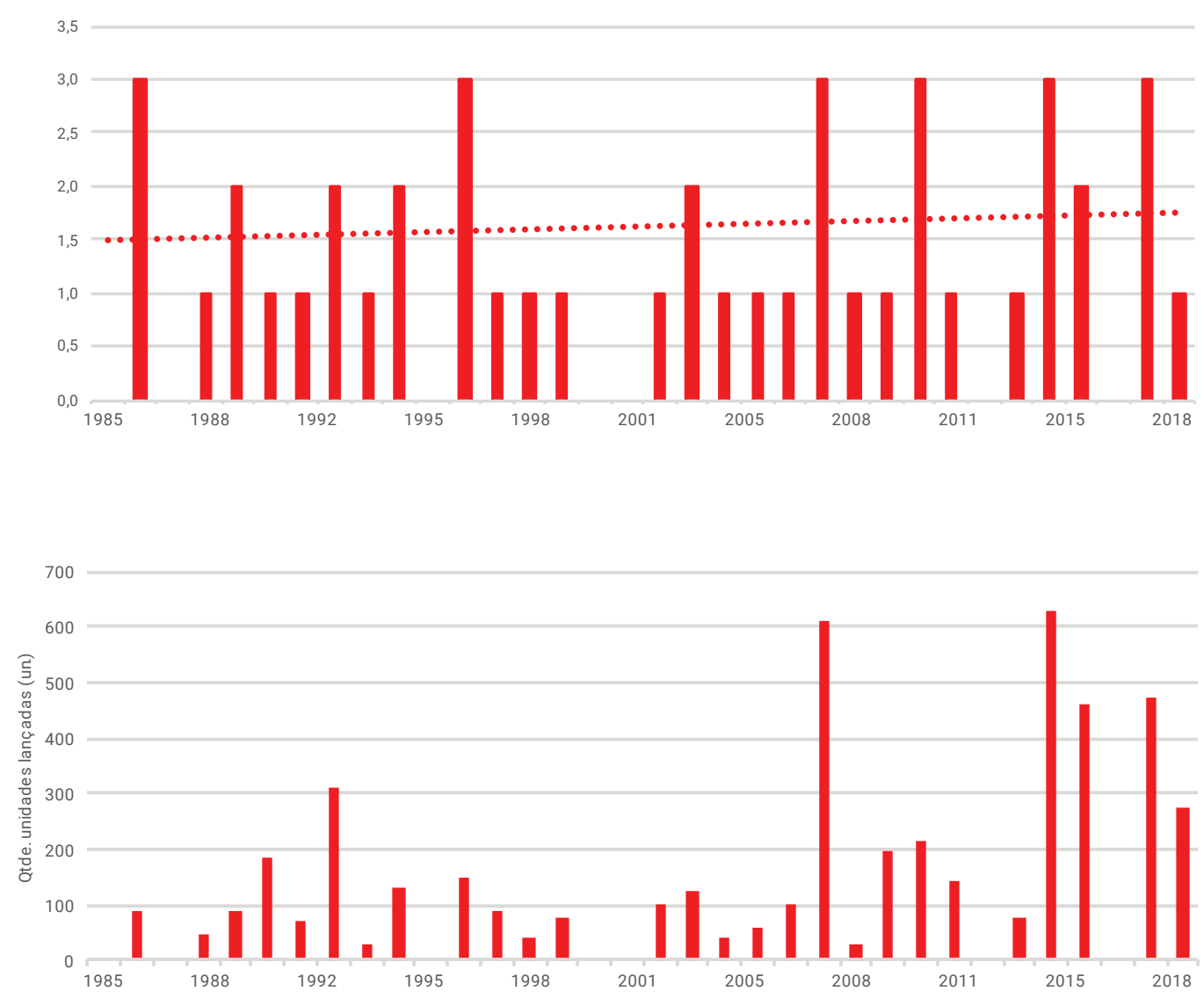

Gráf. 3.2.1

Lançamentos por ano ZEM Minhocão.

Embraesp

... Linha de tendência

Gráf. 3.2.2

Número de unidades lançadas por ano ZEM Minhocão. Embraesp
(2002-2018), temos que no primeiro período foram lançados 19 empreendimentos e no segundo 24 , ou seja, um crescimento de $26 \%$ no número de lançamentos no segundo período, número que podemos associar com seguridade ao contexto macroeconômico que citamos nos itens anteriores. Se, por sua vez, separarmos este segundo período em outros 3 períodos de 5 anos, partindo do final ${ }^{75}$ (2014-2018 / 2009-2013 / 2004-2008), podemos observar que no período mais recentes, entre $2014 \mathrm{e}$ 2018 (abarcando os anos posteriores à promulgação do PDE de 2014), foram lançados 9 empreendimentos, contra 6 no período imediatamente anterior (2009-2013) e 7 com relação ao anterior

75. Escolhemos esta periodização tendo em vista o período entre o fim de nosso banco de dados (2018) e o ano de promulgação do PDE (2014) engloba cinco anos. 
deste último (2004-2008). Ou seja, um aumento de $150 \%$ do período 2014-2018 sobre 2009-2013, e $128 \%$ sobre 2004-2008. Podemos, portanto, dizer com base nestes primeiros dados que há um aumento relativo do número de lançamentos imobiliários no período recente (2014-2018) sobre os dois períodos anteriores, contudo os dados não são conclusivos para dizer com segurança que há um aumento decorrente do novo marco regulatório.

Este número de lançamentos pode ser comparado com o número de unidades lançadas, somando as unidades produzidas em cada empreendimento, na busca por aferir os resultados anteriores. Na mesma linha de raciocínio, nos 44 empreendimentos lançados no período (1985-2018) foram produzidas 4.861 unidades residenciais (gráf. 3.2.2). Se dividirmos este período em 2, um prévio ao PDE de 2002 (1985-2001) e outro posterior (20022018), temos que no primeiro período foram lançados 1.323 unidades e no segundo 3.538 , ou seja, um aumento de $221 \%$ do segundo período sobre o primeiro. Seguindo com o mesmo raciocínio anterior e dividindo o segundo período em três de 5 anos (2014-2018 / 2009-2013 / 2004-2008) obtemos que: entre 2014 e 2018 foram lançadas 1.836 unidades, entre 2009 e 2013 foram lançadas 632 e entre 2004 e 2008 foram lançadas 840 unidades. Se revela portanto um aumento de $290 \%$ do período de $2014-2018$ sobre $2009-2013$ e $218 \%$ sobre $2004-2008$. Aqui os números são mais expressivo.

Buscando levantar hipóteses para tal aumento no número de unidades lançadas, a seguir podemos ver no gráfico (gráf. 3.2.3) que cruza números do total de unidades lançadas na ZEM do Minhocão com o total de unidades lançadas por ano na RMSP e no Centro ${ }^{76}$. De forma geral, podemos ver que existe certo paralelismo entre os três recortes (RMSP, Centro e Minhocão), principalmente se compararmos a região central com a ZEM do Minhocão. Mesmo que por momentos se verifiquem movimentos coordenados, percebe-se que, principalmente a partir de 2008, o movimento de ambas é semelhante, lembrando que o

76. A linha que indica o número de unidades lançadas na RMSP se encontra em escala diferente daquelas que indicam as unidades do Centro e da ZEM Minhocão (verificar legenda à direita do gráfico 3.2.3). 
Elevado corta além da região central, a oeste do Bairro da República, a Santa Cecília, Campos Elíseos e a Barra Funda. Constatamos especificamente que o aumento no número de unidades lançadas visto anteriormente a partir do ano de 2014 também pode ser verificado na região do Centro, de forma ainda mais acentuada. Portanto associamos tal crescimento no Minhocão a um processo mais amplo de aumento da atividade imobiliária na região central.

Podemos ver, também, que ao longo de muitos anos a atividade imobiliária associada ao centro da cidade se manteve baixa ou praticamente nula, tendo em vários momentos mais lançamentos no entorno do Minhocão do que nesta região. Comparando com a trajetória dos lançamentos na RMSP, nota-se que o 'boom' imobiliário, que se observa principalmente a partir de 2007 e se manteve relativamente estável até 2014, não pode ser verificado da mesma forma nem na região central da cidade e nem na ZEM do Minhocão. Pelo contrário, quando o ritmo de produção começa a decrescer na RMSP (2014) verificamos um aumento importante no número de unidades lançadas tanto na região central quanto no Minhocão. Isso não quer dizer que estas duas regiões estejam separadas da dinâmica imobiliária mais ampla da metrópole, e sim que existe aqui certa defasagem entre o boom imobiliário metropolitano e a atividade imobiliária que viria a acontecer no centro da cidade.

Se em termos quantitativos podemos afirmar que há uma mudança nos padrões da produção imobiliária na região, tanto em relação à produção antes e depois do $\mathrm{PDE}$ de 2002, quanto antes e depois do PDE de 2014, passamos aqui a analisar este processo em termos qualitativos, especificamente em termos territoriais. A seguir, podemos, então, analisar o mapa (mapa 3.2.1) com a distribuição dos 44 empreendimentos levantados no entorno imediato do Minhocão (em verde a Zona Eixo de Estruturação da Transformação Metropolitana (ZEM) demarcada no zoneamento).

Devemos destacar, em primeiro lugar, de acordo com os números vistos anteriormente, que mesmo a área do entorno do Minhocão sendo tida como uma área historicamente "degradada" ou 


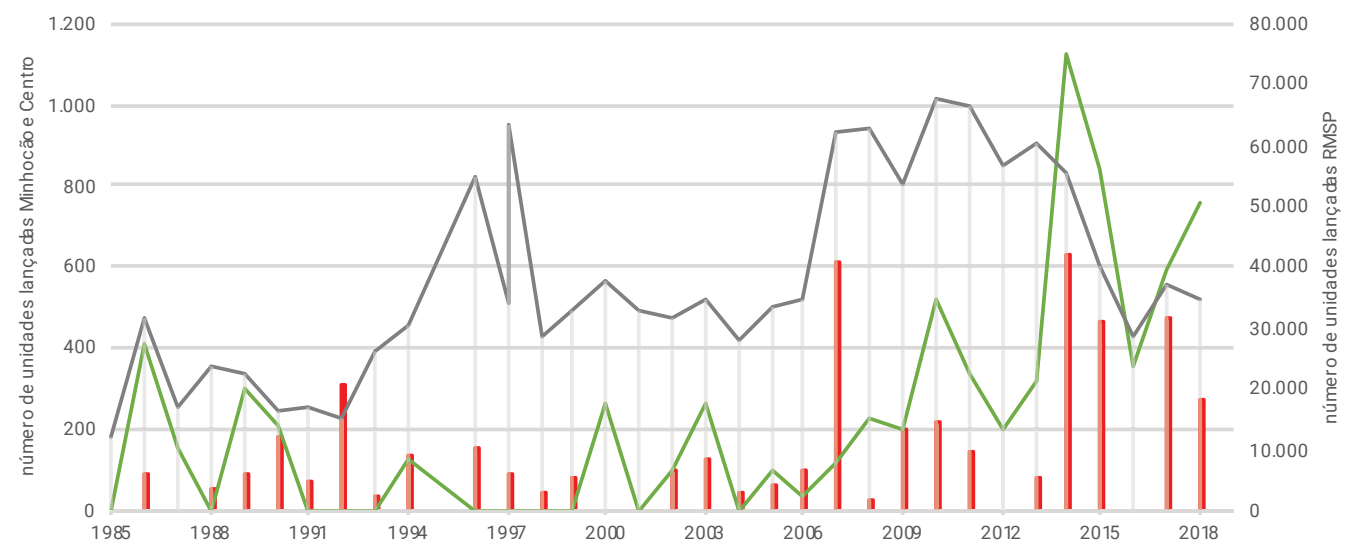

"desvalorizada", a atividade imobiliária se manteve relativamente aquecida em todo o período estudado (1985-2018), porém com manifestações territoriais diferentes ao longo do seu percurso. Podemos verificar, por um lado, que na região entre os bairro de Santa Cecília, Barra Funda e Campos Elíseos, ao norte de Higienópolis, há lançamentos em ambos lados do Elevado ao longo de todo o período analisado. Esta produção coloca em xeque, de

Gráf. 3.2.3

Evolução número de unidades lançadas RMSP, Centro e ZEM Minhocão. Embraesp

- ZEM Minhocão

- Centro

-.. RMSP um lado a ideia de que o mercado imobiliário estaria evitando a região do entorno do Elevado a Oeste; de outro que essa estrutura teria criado uma "cicatriz" na malha urbana, tendo em vista que a produção se realiza em ambas margens e não apenas em uma. $\mathrm{O}$ mesmo não pode ser dito sobre as margens do Elevado entre os bairro Vila Buarque e República, na região mais próxima do centro: até o ano de 2002, portanto ao longo de 17 anos não observamos nenhum lançamento imobiliário realizado nesta porção do território. Nesse sentido, associamos também esse movimento à estagnação da produção imobiliária residencial no Centro da cidade, que verificamos anteriormente.

O primeiro lançamento a ser realizado no entorno do Elevado mais próximo do centro histórico é o Ed. Paradise, na rua Marquês de Itu, 295, produzido em 2002 pela incorporadora Paralela Empreendimentos e Participações Ltda. (fig. 3.2.1). A seguir, podemos ver o anúncio veiculado na Folha de S. Paulo no dia 08 de 


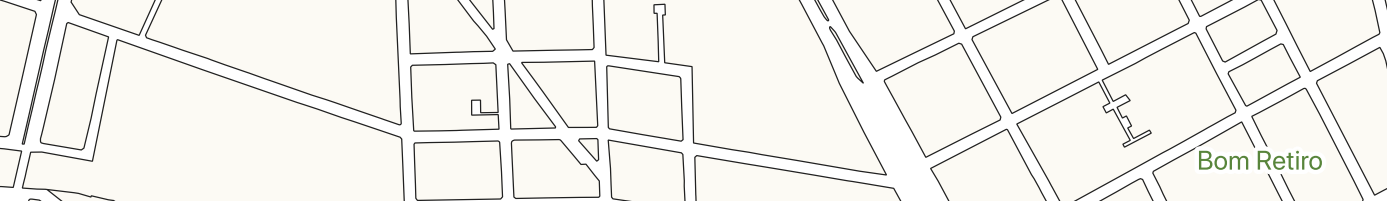


junho de 2002 de dito empreendimento, aqui chamado apenas de "Studio". No anúncio, o empreendimento de 17 andares e 102 unidades de $28 \mathrm{~m}^{2}$ de área útil, tipo "studio", do arquiteto Jonas Birger, é associado aos bairros Vila Buarque / Higienópolis, "prox. ao Shopping Higienópolis" sem fazer menção ao centro de São Paulo do qual ele é constitutivo. $\mathrm{O}$ anúncio nos dá uma pista de como os primeiros empreendimentos buscaram se vincular inicialmente ao bairro nobre de Higienópolis para superar o estigma da degradação criado nas áreas centrais. A superação de uma barreira física é aqui realizada por meio do marketing, que vincula uma região a outra por meio de estratégias discursivas.

Em segundo lugar, podemos dizer que os lançamentos no entorno do Minhocão foram realizados na maioria dos casos a certa distância da estrutura da via expressa elevada, ou seja, poucas vezes implantados imediatamente de frente a ela. Isso corrobora com a ideia da "desvalorização" que os imóveis imediatamente em frente ao Elevado teriam sofrido com a construção da via expressa. No levantamento da Embraesp, podemos ver que esta barreira histórica foi rompida primeiramente com a reforma de um edifício completo, realizada em 1999, no edifício da década de 1950 "Rosemarie e Maria Tereza”, na esquina da rua. Gen. Júlio Marcondes Salgado com a Av. São João. Depois dele, o próximo empreendimento seria o Ed. Cosmopolitan Higienópolis, desta vez um residencial novo, produzido pela MAC Construtora e Incorporadora Ltda. Este prédio de 19 andares e 329 unidades de aproximadamente $35 \mathrm{~m}^{2}$ de área útil, se vale de um térreo com equipamentos condominiais (quadra e salão de festas) para intermediar a relação da torre do edifício com o Elevado, distanciando-o do mesmo. O prédio foi lançado em novembro de 2014 após a promulgação do PDE. Ainda depois dele, foram lançados imediatamente próximos ao Elevado, o Ed. Cosmopolitan Santa Cecília em 2015, também da MAC e o Ed. Bem Viver Consolação, em 2017, da incorporadora Magik JC.

Como vimos no capítulo 1, a produção de unidades habitacionais pequenas não é uma novidade desse período, tendo em vista o número de quitinetes lançadas entre as décadas de 1950
Mapa 3.2.1

Lançamentos na ZEM

Minhocão entre 1985 e

2018. Embraesp

ZEM Minhocão Lançamento

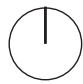




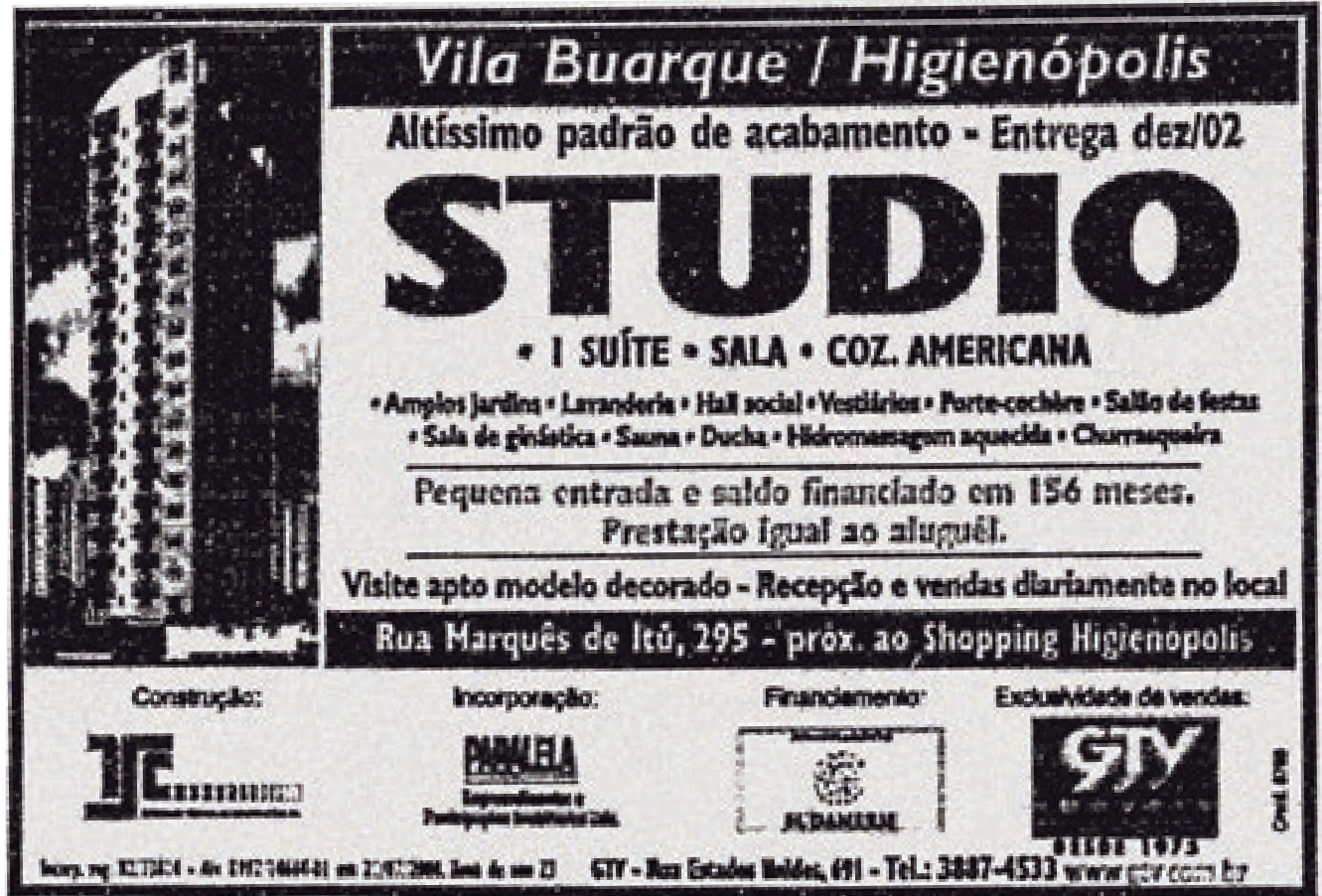

Fig. 3.2.1

Anúncio publicitário do empreendimento "Studio". Folha de S. Paulo, 2002. e 1960. Adiante, observamos (gráf. 3.2.4) a evolução da média das unidades habitacionais lançadas por ano, correlacionando a produção na RMSP com aquela na região central, Santa Cecília, Barra Funda e especificamente na ZEM do Minhocão. Observamos que existe uma diferença grande, principalmente no início da série, entre o tamanho médio das unidades: entre 1985-1989, na RMSP (cor preta) a média das áreas das unidades lançadas era de $122 \mathrm{~m}^{2}$, contra $30 \mathrm{~m}^{2}$ no Centro (cor verde). Podemos ver que na área da região do Minhocão as unidades se encontram quase na média entre a RMSP e o centro, com $62 \mathrm{~m}^{2}$, áreas menores do que na região da Barra Funda (laranja) e Santa Cecília (amarelo). Na medida que nos aproximamos da atualidade, porém, podemos verificar que a diferença entre o tamanho das unidades lançadas na RMSP e aquelas do centro da cidade se comprime. Nos últimos 5 anos do período estudado (20142018), vemos que a área média das unidades na RMSP é de $72 \mathrm{~m}^{2}$, no Centro ainda na faixa dos $36 \mathrm{~m}^{2}$, na Barra Funda $57 \mathrm{~m}^{2}$, na Santa Cecília $39 \mathrm{~m}^{2}$ e na ZEM do Minhocão também $39 \mathrm{~m}^{2}$. Ou seja, a diferênça entre o maior e o menor valor lançado passa 


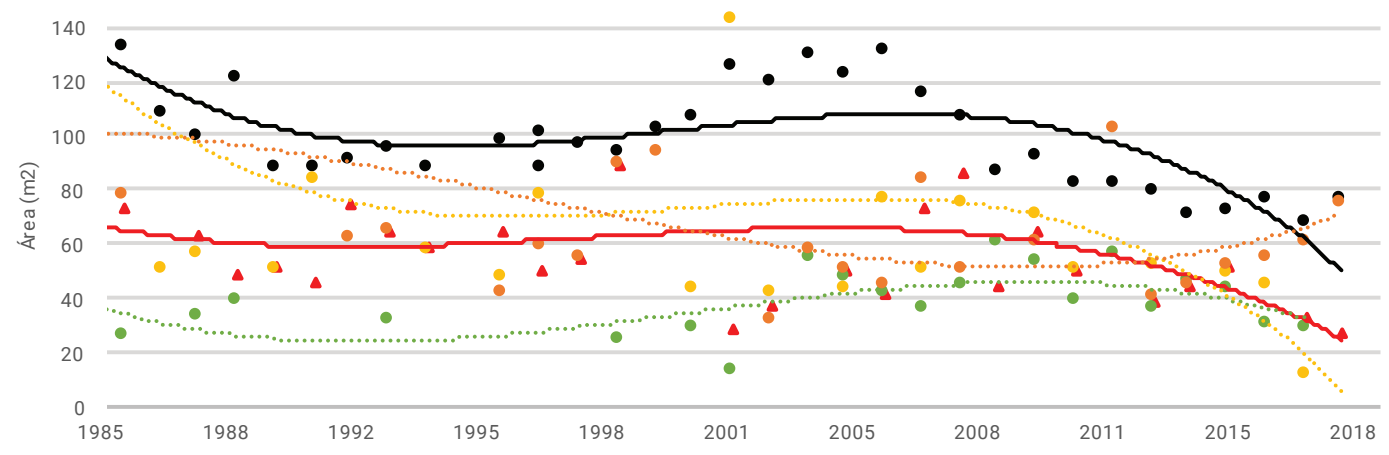

de $92 \mathrm{~m}^{2}$ para $36 \mathrm{~m}^{2}$, demonstrando uma tendência à homogeneização do produto imobiliário em termos de área. Homogeneização que aproxima o produto da metrópole àquele que se realizou historicamente no Centro.

Sob outro ponto de vista, podemos analisar a área média dos terrenos utilizados para a produção dos empreendimentos (gráf. 3.2.5). Em preto, podemos ver a área dos terrenos na RMSP (em tracejado preto a linha de tendência desses valores): apesar de apresentar grandes flutuações verificamos que na região metropolitana, a partir de 1985, há uma tendência ao uso de terrenos maiores que muda partir de 2007 e volta a cair na atualidade para áreas de terreno muito similares ao patamar de 1985. Devemos destacar que a escolha por terrenos maiores ou menores, apesar de, sim, se tratar de um direcionamento intencional do mercado, nos diz também sobre a disponibilidade de terrenos de grandes dimensões em certas localidades. Este gráfico também nos indica um possível movimento do mercado imobiliário rumo às regiões periféricas, em que a quantidade de terrenos de grandes dimensões é maior e um posterior retorno para a centralidade, que poderia estar atrelado aos novos marcos regulatórios. A atratividade, portanto, dos terrenos de menores dimensões também poderia ser uma aproximação da atividade às regiões centrais.

Ao compararmos, ainda em termos quantitativos, os resultados do gráfico que trata das áreas dos terreno com aqueles que tratam das áreas das unidades, podemos concluir que se, antigamente (1985), 


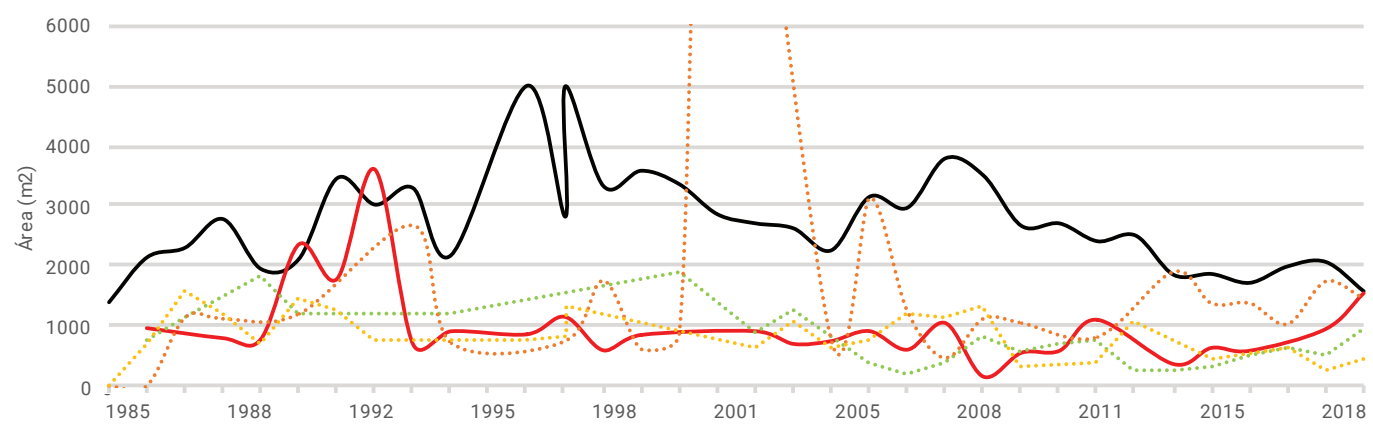

Gráf. 3.2.5

Evolucão da área média dos terrenos utilizados por ano. Embraesp

- ZEM Minhocão

... Centro

... Santa Cecília

... Barra funda

- RMSP na média produzia-se em um certo terreno unidades de um certo tamanho, hoje em dia (2018) o mercado voltou a produzir em terrenos muito semelhantes em área, unidades quatro vezes menores. O resultado nos mostra uma tendência à intensificação do uso do solo não por meio do seu consumo em extensão, mas pela veiculação de um produto imobiliário "novo" ou bem menor que a média de períodos anteriores. Analisando a média do tamanho das unidades na região central (em verde, no gráf. 3.2.4) verificamos que esse "novo" produto talvez não seja tão novo nesta região, como vimos também no primeiro capítulo. Com base nestes dados, podemos levantar a hipótese de que o centro da cidade e consequentemente o Minhocão passam a ser alvo de uma nova produção imobiliária, não só porque o mercado passa por uma reestruturação na qual terrenos menores voltam a ser atrativos para a produção, mas também porque aqui encontramos um produto imobiliário que é historicamente ofertado e consumido na região e que na reestruturação da produção imobiliária ganha interesse.

No sentido de discutir a intensificação do produção imobiliária sobre a terra, ainda com dados da Embraesp, trazemos (gráf. 3.2.6) a evolução do coeficiente de aproveitamento efetivo ${ }^{77}$

77. Diferentemente daquele utilizado nos marcos regulatórios, nos quais o CA trata apenas das áreas computáveis, aqui incluímos no coeficiente de aproveitamento tanto as áreas computáveis como as não computáveis para nos aproximarmos daquele real. 


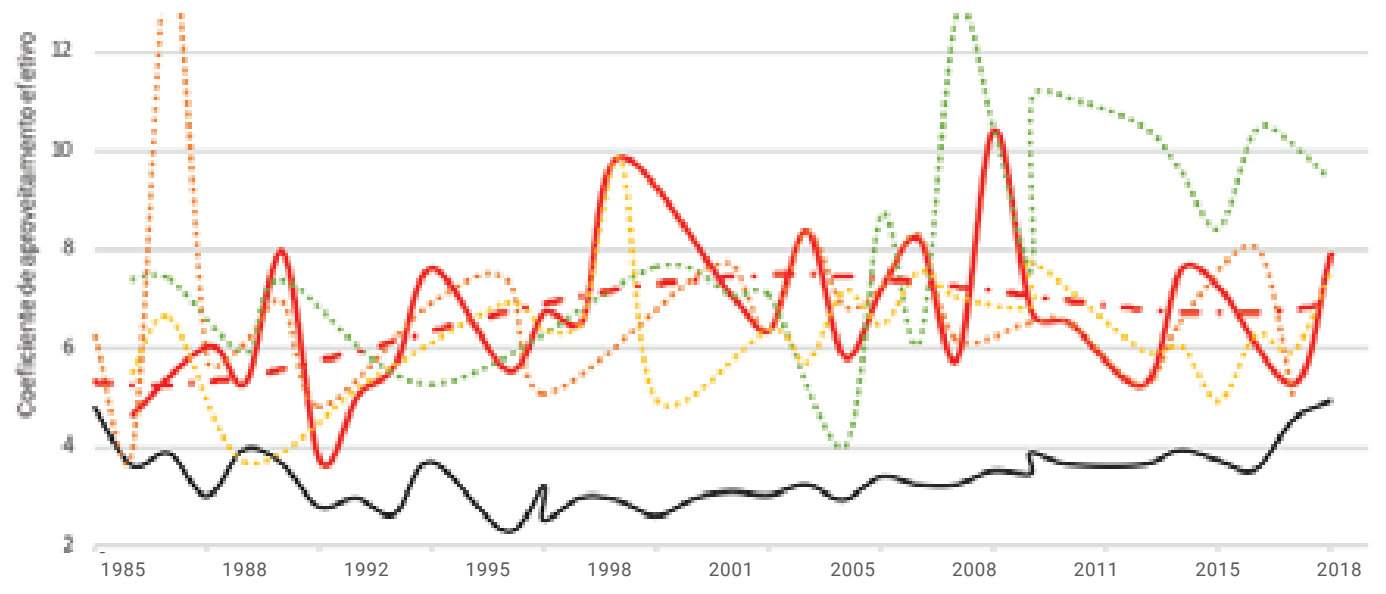

(CAe) do terreno (área total construída sobre a área do terreno). Em preto, a evolução deste índice na RMSP: vemos uma ligeira concavidade no meio do período estudado, inversa (porém mais suave) àquela do gráfico anterior (que trata da área do terreno). Verificamos que a média da metrópole começa com um CAe de, aproximadamente, 5, no meio do período passa por um CAe de 3 para no final do período voltar para o CAe de 5. Portanto, do final da década de 1990 até os dias atuais verificamos um aumento da intensificação da produção imobiliária na metrópole, coerente com a utilização de terrenos menores, que vimos no gráfico anterior. Sobre a região do entorno do Minhocão, verificamos um CAe sempre acima da média da metrópole, cuja linha de tendência varia entre um CAe 5 e um CAe 7. Verificamos em verde o CAe da região central, muito próxima àquela da região do Elevado, mas que a partir de 2006 se eleva de forma importante para um CAe próximo de 10, a partir de 2008.

Devemos lembrar aqui a importância da Operação Urbana Centro, promulgada em 1997, na elevação deste índice na região, ao permitir um Coeficiente de Aproveitamento Máximo ${ }^{78}$ (CAm) de 6 para edifícios de uso residencial sem o pagamento de contrapartida financeira. Mesmo tendo uma adesão do merca-

\section{Gráf. 3.2.6}

Evolucão do coeficiente de aproveitamento efetivo (CAe) RMSP.

Embraesp

$$
\begin{aligned}
& \text { - ZEM Minhocão } \\
& \text {.. Centro } \\
& \text {.. Santa Cecília } \\
& \text {.. Barra funda } \\
& \text { — RMSP }
\end{aligned}
$$




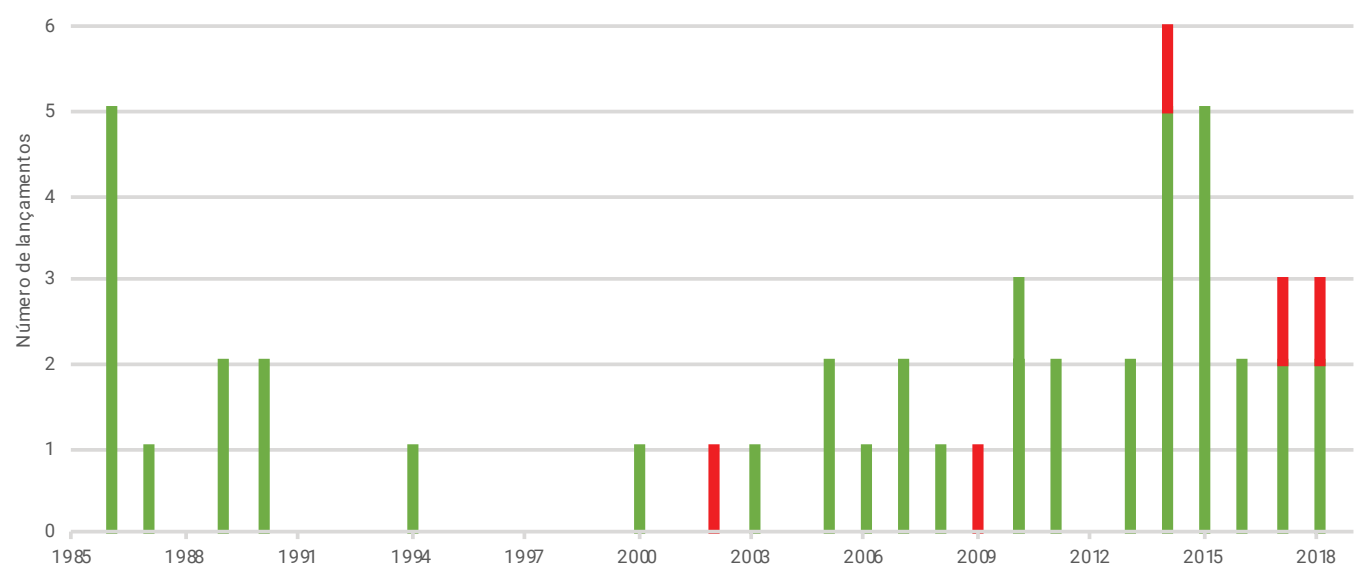

Gráf. 3.2.7

Evolução dos lançamentos no Centro (dist. Sé e República).

Embraesp

- Centro

- Centro e ZEM

Minhocão do relativamente baixa, principalmente quando comparada às Operações Urbanas Consorciadas Faria Lima e Água Espraiada, a partir da promulgação da OU podemos contar com um efetivo aumento do número de empreendimentos, principalmente com relação ao período anterior. No gráfico a seguir, (gráf. 3.2.7) vemos o número de lançamentos na região central no período analisado: podemos contar que antes de 2002 foram lançados 12 empreendimentos nesta região; depois, 35 , dos quais 5 são na ZEM do Minhocão (cor vermelha). Podemos, por aqui, portanto, mensurar a relativa importância da produção imobiliária na região do entorno do Elevado sobre o resto da região central.

Finalmente, cabe analisar a evolução do número de vagas lançadas por empreendimentos ao longo do tempo, tendo em vista que as áreas de garagem representaram historicamente uma importante parte da área total construída. Lembrando ainda que o PDE de 2002 exigia um número mínimo de vagas por área computável e que no PDE de 2014 essa exigência foi retirada, passando para o extremo oposto ao instaurar uma área máxima de garagem passível de ser construída sem ser computável. O gráfico (gráf. 3.2.8) novamente se inverte, nota-se que nas regiões mais centrais, incluindo a ZEM do Minhocão, os lançamentos imobiliários produziram número menor de vagas do que na média da RMSP. Tendo em vista que em terrenos menores a construção de 


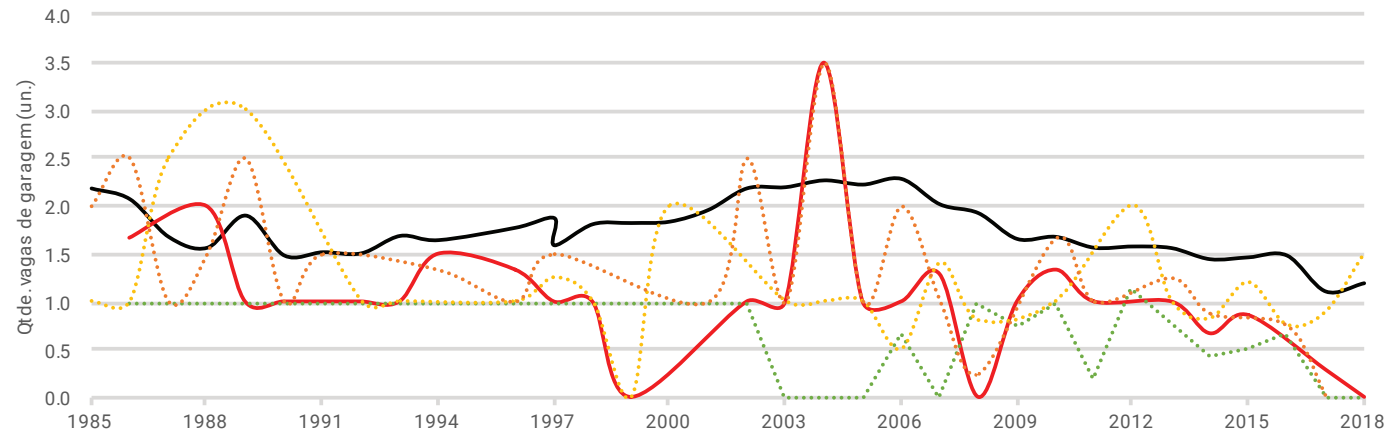

garagens encarece de forma significativa o preço da construção, é esperado aqui que seja construída historicamente uma menor quantidade de vagas. Falando especificamente sobre o Centro, devemos destacar que a OU Centro desobrigava a construção de garagens para os empreendimentos residenciais. Vemos que a partir de 2014, quando a exigência de um número mínimo de garagens foi retirada no PDE, há uma diminuição no número de vagas lançadas em toda a RMSP. Verificamos, ainda, que a partir de 2005 há um uma diminuição geral do número de vagas por empreendimento, que pode ser relacionada tanto ao uso de terrenos menores quanto ao avanço da produção com perfil mais "econômico", com menor quantidade de vagas.

A partir daqui, nos debruçamos especificamente nos lançamentos recentes (2010-2018) no entorno do Minhocão. Neste período, podemos contabilizar 14 lançamentos imobiliários cadastrados na Embraesp, dos quais 13 são edifícios novos, e um é uma reforma completa de um imóvel já existente. Na busca por elencar mudanças na produção do espaço que eles desencadeiam, nos deteremos para discutir as seguintes questões: a sua implantação (sua relação com a rua), seu porte (quantidade de unidades), as tipologias das suas unidades habitacionais (tamanho e número de dormitórios) e as emenidades condominiais que incluídas no edifício.
Gráf. 3.2.8

Evolucão do número médio de vagas por unidade hab. lançada RMSP. Embraesp

- ZEM Minhocão

... Centro

... Santa Cecília

... Barra funda

- RMSP 


\section{Lançamentos recentes no entorno do Minhocão: mercado em reforma}

Iniciaremos a discussão justamente pelas reformas, por entendermos que este segmento do mercado se constituiu historicamente como um pioneiro na produção imobiliária tanto no Minhocão quanto no Centro. Discutimos aqui, portanto, os lançamentos em edifícios construídos em um período anterior que por meio de uma reforma geralmente interna da edificação se constituem enquanto novo lançamento, envolvendo melhorias na infraestrutura e graus diferentes de intervenções na fachada e na planta original do edifício. Na linguagem do marketing imobiliário contemporâneo, estas reformas são chamadas de retrofits. Em 2010, uma matéria da Folha de S. Paulo intitulada "Mercado em reforma", anunciava o aumento da oferta de novas unidades habitacionais no Centro, encabeçadas por este tipo de lançamento, cuja vantagem estaria associada à rapidez na realização do negócio, o valor mais baixo das unidades e uma rentabilidade de até $30 \%$ para o incorporador ${ }^{79}$. Para a análise a seguir, nos valemos dos lançamentos cadastrados na Embraesp, no levantamento realizado por Beatriz Kara José (2010) e no levamento de campo realizado para este trabalho.

$\mathrm{Na}$ região que estamos analisando, verificamos no cadastro da Embraesp apenas dois lançamentos realizados em edifícios produzidos em um período anterior, trata-se de uma reforma realizada em 1999 no edifício "Rosemarie e Maria Tereza" e outra realizada em 2014, no edifício Paulicéia. O primeiro deles, localizado na esquina da R. Gen. Júlio Marcondes Salgado com a Av. São João, do portfólio da incorporadora Ingaí . Esta incorporadora foi fundada em 1949 e a partir 1988, "priorizou a incorporação imobiliária construindo edifícios e condomínios horizontais nos bairros mais nobres da cidade de São Paulo"80 e, ainda mais recentemente, a construção de loteamentos fechados no interior paulista. A Ingaí, em cujo quadro societário figura o atual presidente do SECOVI, Claudio Bernardes, também é

79. De Castro, Letícia. Mercado em reforma. Folha de S. Paulo, 25 de abril de 2010, caderno classificados imóveis 1.

80. Página web da incorporadora Ingaí (link para site na bibliografia). 
responsável por outra reforma, realizada em 2005, na rua Sete de Abril, no centro da cidade, que tirou proveito de um antigo Hotel para oferecer unidades de um dormitório (Kara José, 2010, p. 205). O Ed. Pauliceia, localizado na rua Bento Freitas, foi realizado pela L1 Empreendimentos e lançou unidades de um dormitório em um antigo edifício de escritórios, chamado Ed. Benel. O Pauliceia é o único empreendimento que figura na Embraesp da L1, cujo quadro societário conta com a participação Manuel Otavio Lotufo, sócio de várias outras empresas do setor imobiliário, como a Edge Incorporações, Benel Planejamentos Imobiliários e fundador da Sequoia Desenvolvimento Imobiliário S.A., que, em 2008, foi adquirida pelo fundo Endurance Capital Partners ${ }^{81}$.

Kara José explica que "as pesquisas da Empresa Brasileira de Estudos de Patrimônio (Embraesp) mostram alguns lançamentos oriundos de edifícios reformados, mas não dão a dimensão da quantidade de empreendimentos do tipo que estão acontecendo no Centro" (Kara José, 2010, p. 202) portanto, "foi necessário uma pesquisa de campo da autora para elencar 41 edifícios que foram reformados desde o final dos anos 90"(Kara José, 2010, p. 202). Destes 41, sete encontram-se dentro da ZEM do Minhocão, lançados principalmente por duas incorporadoras: Centro Vivo e Romão Empreendimentos Imobiliários. Da Centro Vivo, ainda podemos citar mais dois empreendimentos na região, ausentes no levantamento de Kara José mas encontrados no site da incorporadora (Ed. Nova Esperança e Cond. Ricardo Marques).

Sintetizamos brevemente certas questões trazidas pela autora sobre estas duas incorporadoras (Kara José, 2010, p. 209-213). Cabe reforçar, a título de exemplo, que segundo a matéria citada anteriormente, a Centro Vivo realizou no centro mais de 20 operações, o que representa um número importante frente ao total dos outros lançamentos imobiliários que vimos nesta região (35). A Centro Vivo foi fundada por Chill Joseph, ex-corretor de imóveis e um dos pioneiros na realização de reformas para ven- 
da em prédios do Centro. Sua atuação tem início em 1996, em imóveis residenciais que não demandavam demasiadas obras, seu público principal são trabalhadores do Centro de classe média, e ele relata que a maior dificuldade na transação relaciona-se com o desmembramento da matrícula associada antigamente ao terreno. A empresa Romão Empreendimentos Imobiliários, por outro lado, foi fundada por Jaime Romão, também pioneiro da reforma de edifícios no Centro. Romão além de já ter comprado imóveis inteiros de "famílias tradicionais", também realiza a compra de unidades separadamente, uma a uma, em edifícios ocupados que envolvem processos de despejo para obter gradualmente a propriedade completa do imóvel e realizar a reforma. Ele relata que os imóveis preferenciais para a compra são os hotéis e seu público envolve pessoas majoritariamente de classe média-baixa. Tanto a Centro Vivo quanto a Romão Empreendimentos Imobiliários procuram fazer reformas simples e rápidas, sem modificações de planta para colocar os imóveis no mercado com rapidez.

Kara José destaca certo pioneirismo neste tipo de empreendedores, associado à produção de imóveis populares. Sobre esse tipo de produção, a autora aponta:

Os empreendedores de reformas acima apresentados são bastante específicos do Centro, e foram atraídos principalmente pela oportunidade de negócio representada na existência de imóveis vazios e ociosos, passíveis de reabilitação. São empresários de menor porte, que trabalham com um capital menor e atendem uma demanda de menor poder aquisitivo - um perfil de investidor diferente daquele enfocado por instrumentos como a Operação Urbana Centro, por exemplo. Eles estão ocupando um nicho de mercado que até agora estava vago, e que é típico do Centro atual: a reabilitação de edifícios ociosos para população de renda abaixo da média (Kara José, 2010, p. 227).

No caso da Ingaí e da L1 Incorporações, empresas presentes no cadastro da Embraesp, podemos verificar um perfil diferente daquele que Kara José trata, Ambas fundadas por incorporadores que trabalham com um leque mais amplo de empreendimentos e ambas 
com produções de edifícios novos de alto padrão e grande porte em áreas nobres da cidade. Neste tipo de empreiteiras, a reforma de edifícios parece como um empreendimento a mais a ser realizado na cidade, oportunidades que são aproveitadas ocasionalmente sem constituir o ramo principal da atividade da empresa.

Na pesquisa de campo, podemos perceber, ainda, novos lançamentos, realizados em edifícios antigos, que não se encontram no cadastro da Embraesp nem no levantamento de Kara José, tratam-se de 3 empreendimentos realizados pela empresa Ilion Partners: o Marajó, o Juliana Torres e o 433. Adiante pode-se verificar o mapa contendo todos estes imóveis (mapa 3.2.2) Como anunciado no seu site "a Ilion Partners é uma empresa de investimento imobiliário especializada em reforma de prédios antigos no Centro expandido"82 cujo slogan é "regeneração urbana pelo investimento imobiliário" ${ }^{\text {"3 }}$. A mesma declara no seu site que "além de buscar retornos financeiros alinhados com as melhores opções do mercado, todos os projetos têm ambição de contribuir positivamente aos entornos urbanos onde estão localizados" ${ }^{\prime 34}$.

Dos três empreendimentos, o Marajó e o Juliana Torres, localizados entre as ruas Major Olímpio da Silveira e a rua Conselheiro Brotero (fig. 3.2.3), um ao lado do outro e de frente ao Elevado, foram realizados para a revenda de unidades habitacionais reformadas. Ambos oferecem unidades de dois e três dormitórios, além de térreo comercial; nenhum dos dois oferece equipamentos condominiais.

Já o empreendimento 433 surgiu da transformação de um antigo hotel (Hotel Jaguar), localizado na Av. Duque de Caxias, em uma residência para estudantes com 125 camas. O empreendimento está anunciado no site Uliving Student Housing, do grupo VBI Real Estate, empresa que pretende lançar 2.000 camas até

82. Página web da incorporadora Ilion Partners (link para site na bibliografia).

83. Idem.

84. Idem. 
Fig. 3.2.2

Capa da página web da empresa llion Partners. Ilion Partners, 2020. o final de $2020^{85}$ e possui empreendimentos em São Paulo, Rio de Janeiro e Ribeirão Preto. No 433, são oferecidos três tipos de unidade: três de uma cama por unidade ( $\mathrm{R} \$ 2.000,00 /$ mês) e uma, cuja unidade é compartilhada entre 6 camas ( $R \$ 1.000,00 /$ cama/mês), na imagem ao lago verificamos duas plantas dessas (fig.3.2.4). Esta estratégia contribui para potencializar as rendas imobiliárias que resultaram, segundo reportagem, em um faturamento de cinco milhões de reais em 2019 e que em 2020 pretende atingir a marcar dos 10 milhões de reais ${ }^{86}$.

No caso do Edifício Juliana Torres, a Ilion contou com a participação da empresa Centro Vivo para fazer a incorporação e as vendas. Cabe destacar que as lojas do térreo deste empreendimento figuram no plataforma Geosampa como de propriedade da Edge Investimentos, empresa de Manuel Otávio Lotufo, sócio da L1 Incorporações. Portanto, trata-se aqui de um pool de empresas atuando "em rede" (Edge Incorporações, Centro Vivo e Ilion Partners). Por outro lado, Ilion contou com a parceria da MMC Investimentos nos empreendimentos Marajó e 433, empresa de sócios franceses que cria, estrutura e gere projetos de desenvolvimento imobiliário com alta liquidez ${ }^{87}$. Ambas trabalham com uma equipe enxuta, de menos de 10 pessoas, envolvendo profissionais com experiência no mercado financei-

85. Fonseca, Mariana. Esta empresa de residência estudantil está transformando as repúblicas. Exame, 28 de setembro de 2019 (link para site na bibliografia).

86. Idem.

87. Página web da empresa MMC Investimentos (link para site na bibliografia). 


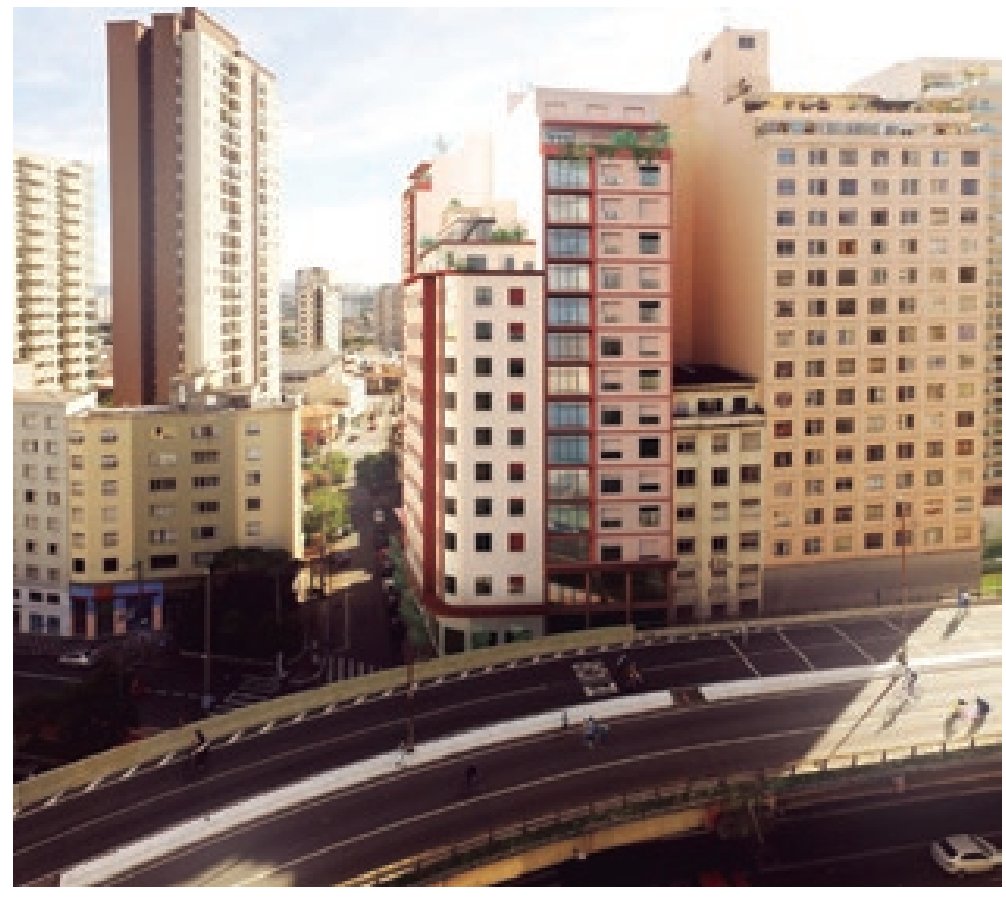

ro atrelado ao imobiliário. Na apresentação da MMC ela define seus objetivos da seguinte maneira.

O objetivo da MMC é identificar oportunidades com potencial de crescimento substancial e auferir um elevado retorno sobre investimento para nossos investidores. A identificação de parceiros locais experientes e com excelente reputação é fundamental para o sucesso dos nossos investimentos. A MMC se apoia nesses parceiros para identificar oportunidades que não estão no mercado, coordenar os aspectos políticos e respeitar as obrigações regulatórias.

(...) A crença da MMC é que o conhecimento local e de rede, associado com a expertise financeira e visão de negócios, são recursos únicos para ter sucesso em seus respectivos mercados. ${ }^{88}$
Fig. 3.2.3

Imagem de divulgação do Ed. Marajó (esquerda) e Juliana Torres (direita). Ilion Partners, 2020.

Conseguimos verificar até aqui uma mudança entre o perfil do empreendedor, levantado por Kara José, os pioneiros, e esses novos 
Fig. 3.2.4

Plantas de divulgação das unidades do empreendimento Uliving 433. Uliving 433, s/d.
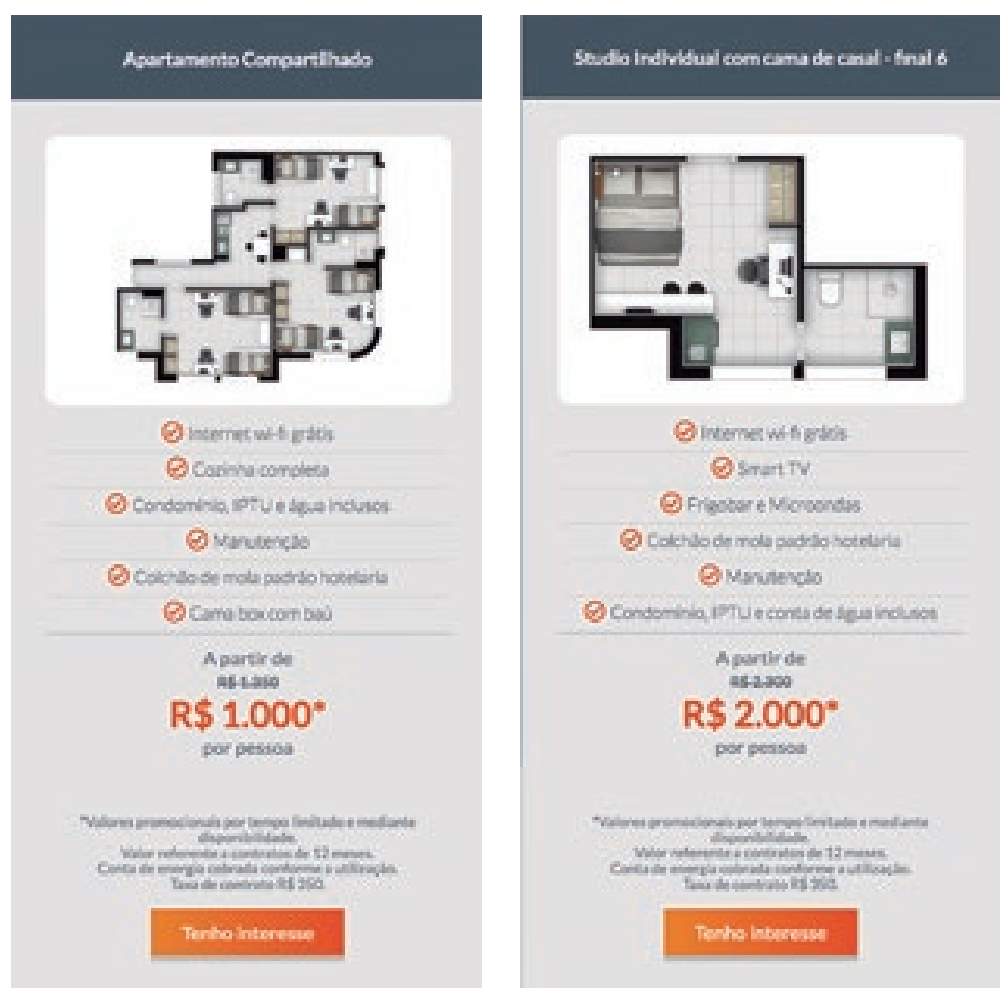

empresários. Por um lado, grande investimento em marketing: perceptível em uma simples visita a cada um dos sites das empresas, além da criação de site específico para cada empreendimento, com o investimento em simulações $3 \mathrm{~d}$ e um clara preocupação com o design. Verificamos ainda que o perfil dos profissionais reforça o conhecimento e a experiência em outros negócios financeiros, e a própria forma de apresentar a empresa procura mais do que demonstrar conhecimentos no setor da (boa) construção, mostrar um bom tato para negócios com alto retorno para os investidores.

Na relação com o Elevado, devemos destacar a ação que a incorporadora realizou sobre o mesmo em abril de 2019, buscando atrair compradores durante o período de fechamento para o tráfego de veículos (fig. 3.2.5). Verificamos pessoas vestidas de vermelho distribuindo bexigas brancas que também podem ser encontradas em uma unidade habitacional do lançamento, voltada para o Elevado. Aqui, podemos ler as placas de "vende-se" e mais abaixo "more no parque Minhocão". 


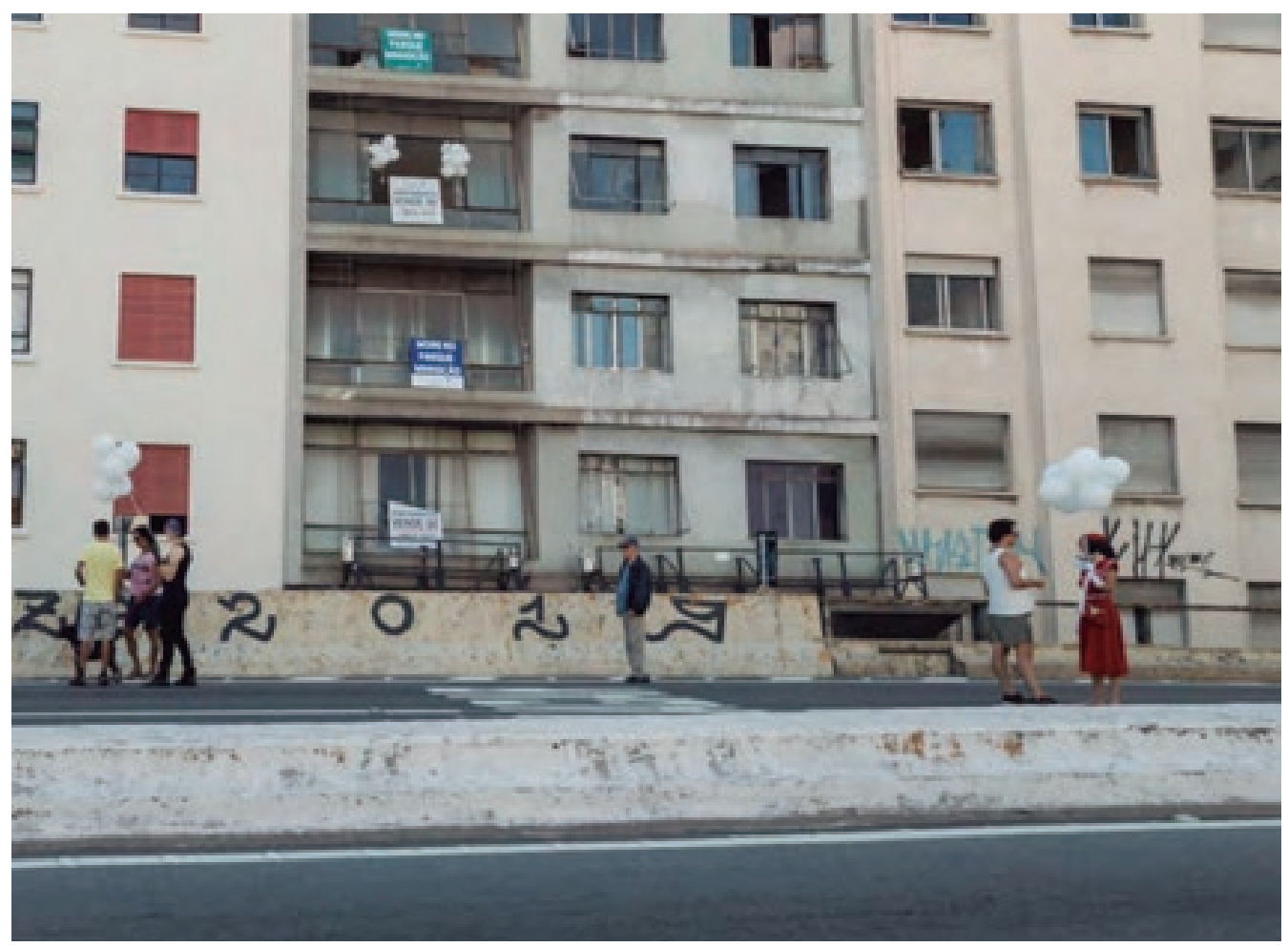

\section{Lançamentos recentes no entorno do Minhocão: mercado dos novos}

A seguir nos debruçamos especificamente sobre os outros 13 empreendimentos "novos" realizados no entorno do Minhocão a partir de 2010 (mapa 3.2.3) e cadastrados na Embraesp. Devemos destacar de início que desses edifícios, um está cadastrado sem nome e não pudemos verificar o seu lançamentos, e 10 estão vinculados a uma marca que engloba um conjunto maior de lançamentos, são eles: Exclusive Higienópolis, Setin Downtown São João, You Newtown, Cosmopolitan Higienópolis e Santa Cecília, Helbor Trend Higienópolis, Smart Santa Cecília, VN Nova Higienópolis, Bem Viver Consolação e Living for Consolação.

Dos 13 edifícios, 10 fazem parte de linhas de produtos que analisamos abaixo para articular a produção específica desta região com movimentos mais amplos do setor. Cabe desde
Fig. 3.2.5

Fotografia de ação para divulgação do Empreendimento Juliana Torres. Alcântara, 2019. 


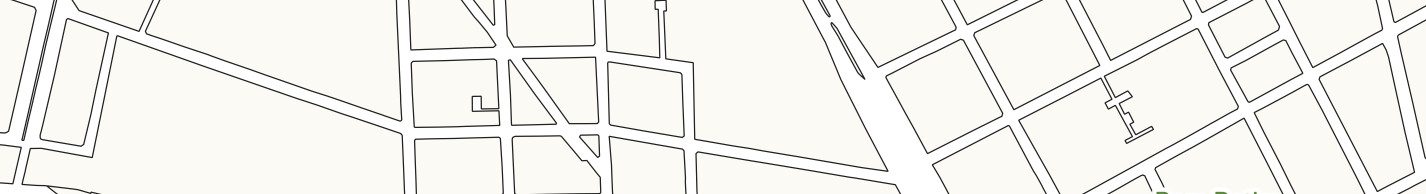


já dizer que a região do Minhocão se caracteriza como um território, no qual algumas empresas estão em concorrência. Levantamos a hipótese de que a criação ou veiculação de um marca associada ao nome do empreendimento sintetiza alguns movimentos simultâneos: (1) aumentar a abrangência do empreendimento, veiculando uma imagem por vários locais da cidade; (2) diminuir gastos com marketing, fazendo um único grande investimento para veicular vários empreendimentos e (3) aumentar a relevância de um certo termo, associado ao novo marketing digital ao aumentar as citações de uma palavra que aumentam o alcance da marca ao atingir um maior número de possíveis compradores. A seguir, analisamos cada uma destas linhas.

\section{Linha Exclusive - Tael Incorporações Exclusive Higienópolis (2010)}

A incorporadora Tael é responsável por esta linha, que inclui 2 empreendimentos, o Exclusive Itaim e o Exclusive Higienópolis, ambos lançados em 2010: o primeiro com 3 dormitórios por unidade, e o segundo com unidades de 2 dormitórios. Ambos tratam-se de edifícios com número total de unidades relativamente baixo, organizados em uma única torre, exclusivamente residencial, isolada das divisas do lote com duas unidades por andar, cada uma de aproximadamente $80 \mathrm{~m}^{2}$ de área útil e duas vagas por unidade. Na mesma região, a Tael também é responsável pelo empreendimento Patricia, lançado em 1986 com unidades de 2 dormitórios e pelo Meridien, lançado em 2004 com 4 dormitórios. Se por um lado o portfólio da Tael conta com 47 empreendimentos, dos quais 4 foram realizados no entorno do Minhocão, por outro a incorporadora não figura no ranking da Embraesp ${ }^{89}$, por isso concluímos se tratar de uma incorporadora menor.
Mapa. 3.2.2

Lançamentos na ZEM

Minhocão a partir de 2010. Embraesp;

Kara José, 2010; llion

Partners; Share Student

Living. Magik JC.

ZEM Minhocão

Lançamento

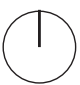



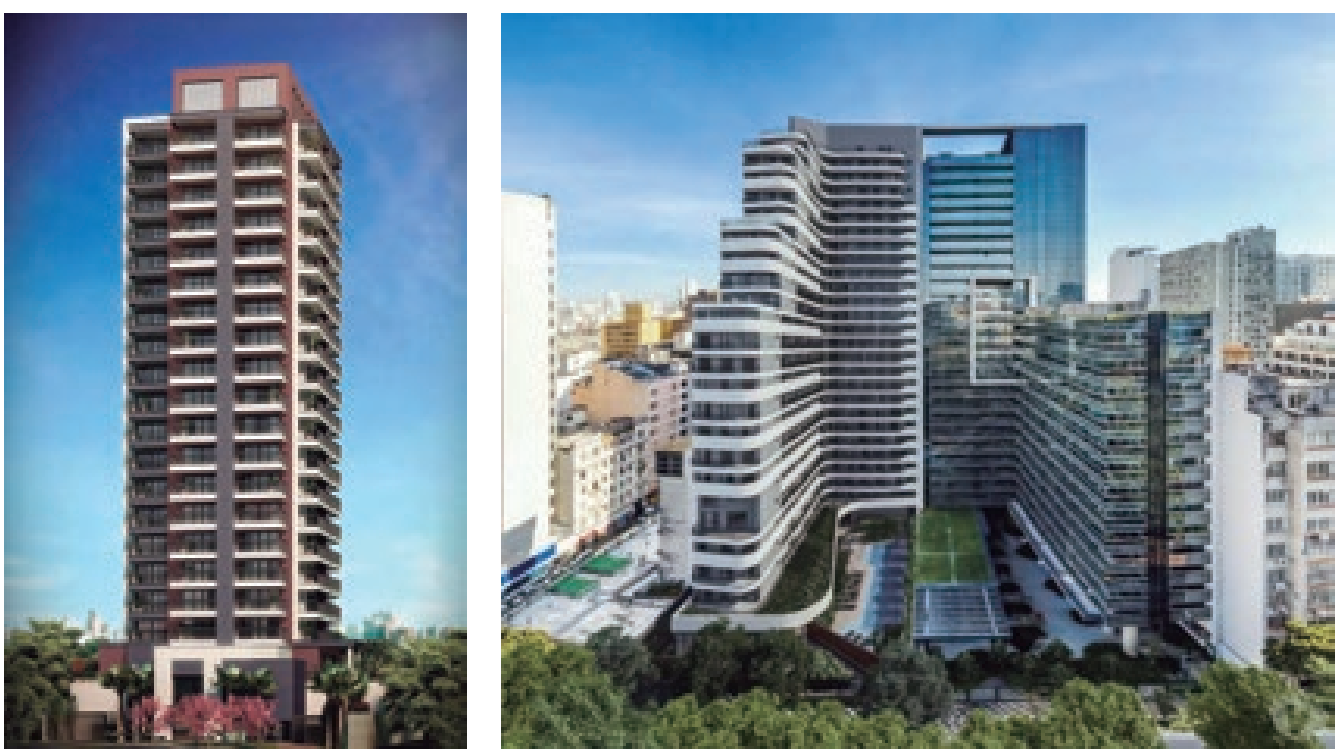

Fig. 3.2.6

Imagem de divulgação do Setin Downtown São João. Setin, s/d.

Fig. 3.2.7

Imagem de divulgação do Setin Downtown Nova República e República. Setin, s/d.

\section{Linha Setin Downtown - Setin Setin Downtown São João (2011)}

Conforme aponta Carmagnani (2019), a linha Downtown da Setin totaliza 7 empreendimentos ${ }^{90}$, todos localizados na região central com número de unidades relativamente alto. Esta linha se caracteriza por assumir a região na qual está inserida, porém traz consigo ideias de renovação e novo "esplendor", todos com unidades tipo studio ou apartamentos de um dormitório, que variam entre $20 \mathrm{~m}^{2}$ e $50 \mathrm{~m}^{2}$. O Setin Downtown São João foi um dos primeiros dessa linha, junto com o Setin Downtown Brigadeiro, ambos com lançamentos cadastrados em dezembro de 2011. O São João é o empreendimento mais barato da linha - a título de comparação, ele foi ofertado por, aproximadamente, $\mathrm{R} \$ 6.500,00 / \mathrm{m}^{2}$ de área útil enquanto que o Setin Downtown Praça de República em 2014, três anos depois, foi ofertado por aproximadamente $\mathrm{R} \$ 14.000 / \mathrm{m}^{2}$.

A linha Downtown é uma das maiores aqui destacadas e uma

90. "São eles: Downtown Brigadeiro, Downtown São João, Downtown República Downtown Genebra, Downtown São Luís, Downtown Estação da Luz e Downtown Praça da Sé. Dos quais estão inseridos no recorte geográfico proposto: Downtown São João, Downtown República e Downtown São Luís" (Carmagnani, 2019, p. 53). 
das que mais assume a sua identidade enquanto um conjunto de empreendimentos, associados a uma localidade. Podemos entender que a incorporadora busca a criação de uma unidade simbólica que no seu conjunto contribui para alavancar cada um dos seus empreendimentos. Conforme aponta Carmagnani (2019), a incorporadora criou para todos os empreendimentos um único stand de vendas, o "espaço ritual" na Av. São Luís com a Av. Ipiranga, "onde reunia corretores, informações, panfletos, maquetes de todos os seus empreendimentos no centro" Carmagnani, 2019, p. 87). Atualmente, a Setin ocupa a posição 25 do ranking de incorporadoras da Embraesp.

Podemos destacar ainda sobre esta linha que 2 dos seus 7 empreendimentos são conjugados a hotéis da linha Uotel Downtown, o São Luís e o Praça da República, com piscina na cobertura, além de apresentar outras amenidades, como salão de festas, jogos, lavanderia coletiva e sauna. Conforme aponta Carmagnani (2019) a Setin é uma empresa já com experiência no ramo hoteleiro, "que passou a atuar neste ramo na década de 1990, como estratégia para enfrentar a crise econômica em que o país se encontrou no início dos anos 1990 com o Plano Collor" (Carmagnani, 2019, p. 122). Ela é responsável junto ao grupo francês Accor pelo "primeiro hotel long stay” de São Paulo (Carmagnani, 2019, p. 122).

Verificamos as imagens de três empreendimentos desta linha (fig.3.2.6 e fig.3.2.7): na primeira imagem, o Downtown São João e na segunda o Downtown República do lado direito do recém-lançado Downtown Nova República. Verificamos um claro deslocamento do primeiro para os dois últimos que trata de uma sofisticação tanto da implantação quanto dos seus elementos construtivos, sendo o primeiro reflexo do PDE de 2002 (edifício isolado no lote e sobre solo de garagens). Verificamos ainda que apesar dos três se tratarem de empreendimentos com alto número de unidades lançadas, o São João lançou 144 unidades, de aproximadamente $40 \mathrm{~m}^{2}$ com uma vaga de garagem, metade das lançadas no Praça da República, com 310 unidades de $30 \mathrm{~m}^{2}$ e $40 \mathrm{~m}^{2}$, sem vagas de garagem. Portanto, além do preço por área útil do primeiro ser praticamente a metade do segundo, notamos nos últimos empreendimentos o dobro de unidades sendo 
Mapa. 3.2.3

Localização dos empreeendimentos da incorporadora You, inc You, Inc, 2020.

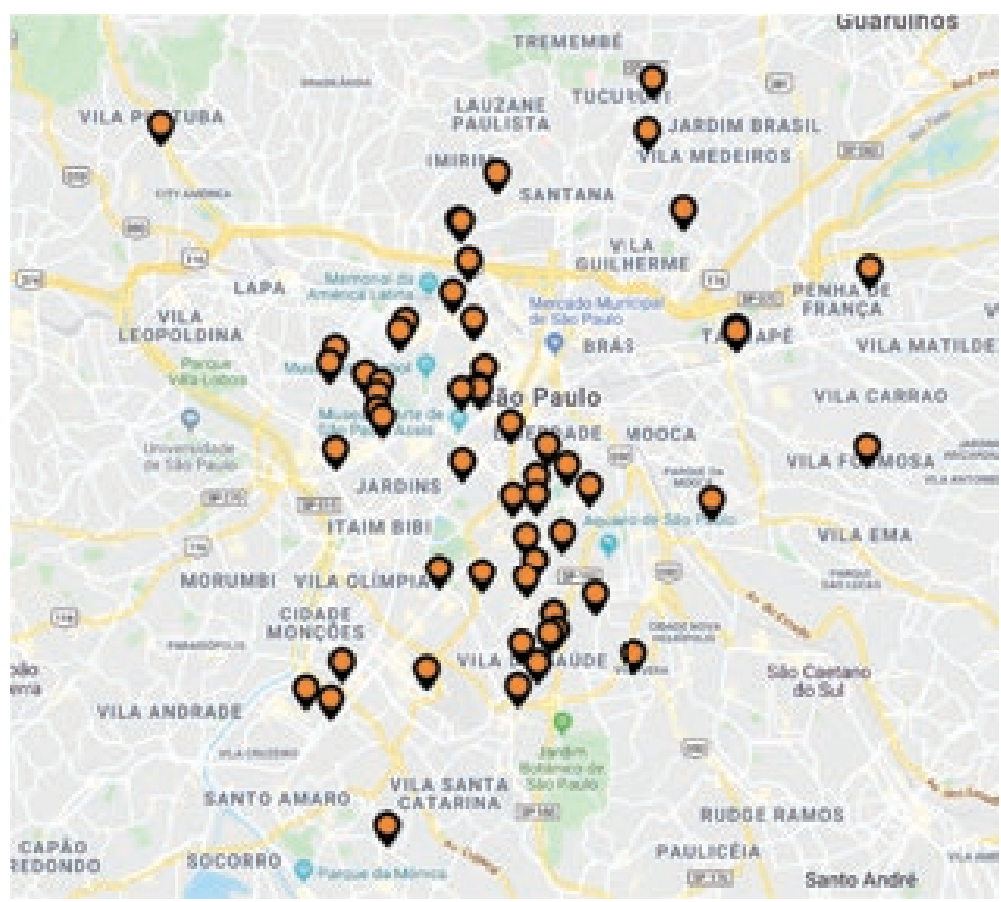

lançadas, sem vagas de garagem e com um edifício muito mais arrochado, o que mais uma vez exemplifica como o preço não está relacionado ao número de unidades unidades ofertado.

\section{Linha You - You, Inc. You Newtown (2013)}

Fundada pelo ex-sócio da Even, Abrão Muszkat, a You, Inc. tem seu foco declarado na "classe média e econômica" não apenas na região central da cidade, mas em um território relativamente amplo, que engloba todas as zonas da cidade como vemos no mapa a seguir (mapa 3.2.3) divulgado pela própria empresa. Computamos nesta apresentação 51 empreendimentos cujos nomes incorporam a identidade da marca, não delimitados numa região, e sim espalhados pela cidade de São Paulo, com apenas um empreendimento localizado fora deste

91. Portal VGV. You, Inc: Fundador e ex-sócio da Even lança incorporadora focada na classe média e econômica com diferencial no atendimento ao cliente. 29 de Setembro de 2010 (link para site na bibliografia). 
município ${ }^{92}$. Conforme aponta a matéria no Portal VGV, portal online de notícias do setor imobiliário, a You, Inc., empresa do tipo sociedade anônima por ações, é "a concretização de um sonho de Muszkat, "criar uma empresa com profissionais gabaritados e experientes, que refletisse suas principais características: empreendedorismo, agilidade, agressividade nos negócios e participação ativa em todo o processo do negócio"93. Atualmente, a You ocupa a posição 34 do ranking de incorporadoras da Embraesp.

Para cada um dos empreendimentos espalhados na cidade, a You oferta condomínios com diferentes tipologias de unidades, que partem dos $20 \mathrm{~m}^{2}$, por exemplo no You, Link Paulista (Bela Vista), até $135 \mathrm{~m}^{2}$, no You Metropolitan (Tatuapé). Na maioria dos casos, são ofertados diferentes tipologias de unidade em um mesmo empreendimento porém no caso do You Newtown a variação é pequena, oferecendo apenas studios e unidades de um dormitório. Na medida em que as áreas das unidades mudam também verificamos uma mudança no valor do metro quadrado de área útil, não necessariamente mantendo uma proporcionalidade.

No empreendimento You Newtown, assim como em muitos outros, a You trabalha em parceria com a Tibério Construções e Incorporações, sendo a Tibério responsável pela construção do empreendimento enquanto a You faz a incorporação. A arquitetura do edifício do arquiteto Jonas Birger guarda muito ainda da fórmula de Adiron, ainda presente no PDE de 2002, com uma torre única isolada no lote, muro no alinhamento, elementos arquitetônicos de linha e grande área de varanda se comparada com o resto da área fechada da unidade. Devemos destacar ainda que a You em duas ocasiões efetivou uma parceria com a empresa de hotéis Ibis, uma em São Caetano e a outra na rua Frei Caneca (Consolação).

92. Trata-se do Hotel You Ibis São Caetano no ABC Paulista.

93. Portal VGV. You, Inc: Fundador e ex-sócio da Even lança incorporadora focada na classe média e econômica com diferencial no atendimento ao cliente. 29 de Setembro de 2010 (link para site na bibliografia). 

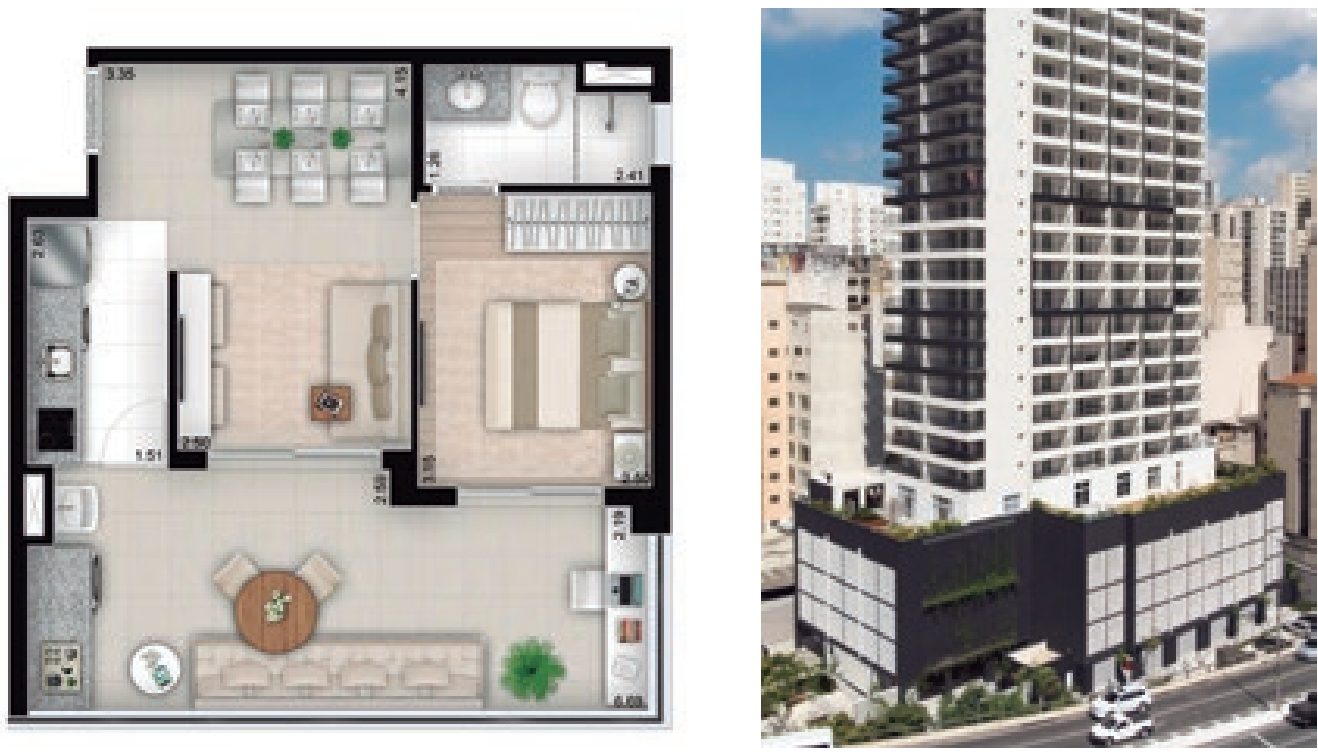

Fig. 3.2.8

Imagem de divulgação da unidade do Emp. Cosmopolitan Santa Cecilia. MAC, s/d.

Fig. 3.2.9

Imagem de divulgação do empreendimento Cosmopolitan Santa Cecília. MAC, s/d.

\section{Linha Cosmopolitan - MAC Construtora e Incorporadora Cosmopolitan Higienópolis (2014) Cosmopolitan Santa Cecília (2015)}

Esta linha de empreendimentos da MAC apresenta três edifícios lançados: Cosmopolitan High Garden (Campo Belo/2013), Cosmopolitan Santa Cecília (Santa Cecília/2014) e Cosmopolitan Higienópolis (Barra Funda/2015). Na época do seu lançamento, a MAC era constituída por uma Joint Venture entre a Mac Investimentos e Participações Ltda. e a Cyrela Brazil Realty S.A. Empreendimentos e Participações, que resultou na Mac Empreendimentos Imobiliários Ltda. Joint Venture, que funcionou do ano de 2006 até abril de 2017 quando o acordo entre ambas deixou de produzir efeitos ${ }^{94}$. A Joint Venture também lançou na região do Minhocão, em 2007, o empreendimento Varanda Expressions, o primeiro empreendimento lançado, aqui, por uma empresa com capital aberto na bolsa de valores ${ }^{95}$. Atualmente, a MAC ocupa a posição 22 do ranking de incorporadoras da Embraesp, e a

94. Cyrela. Comunicado ao mercado. 10 de abril de 2017 (link para site na bibliografia).

95. A Cyrela abriu capital na bolsa de valores em 2006 


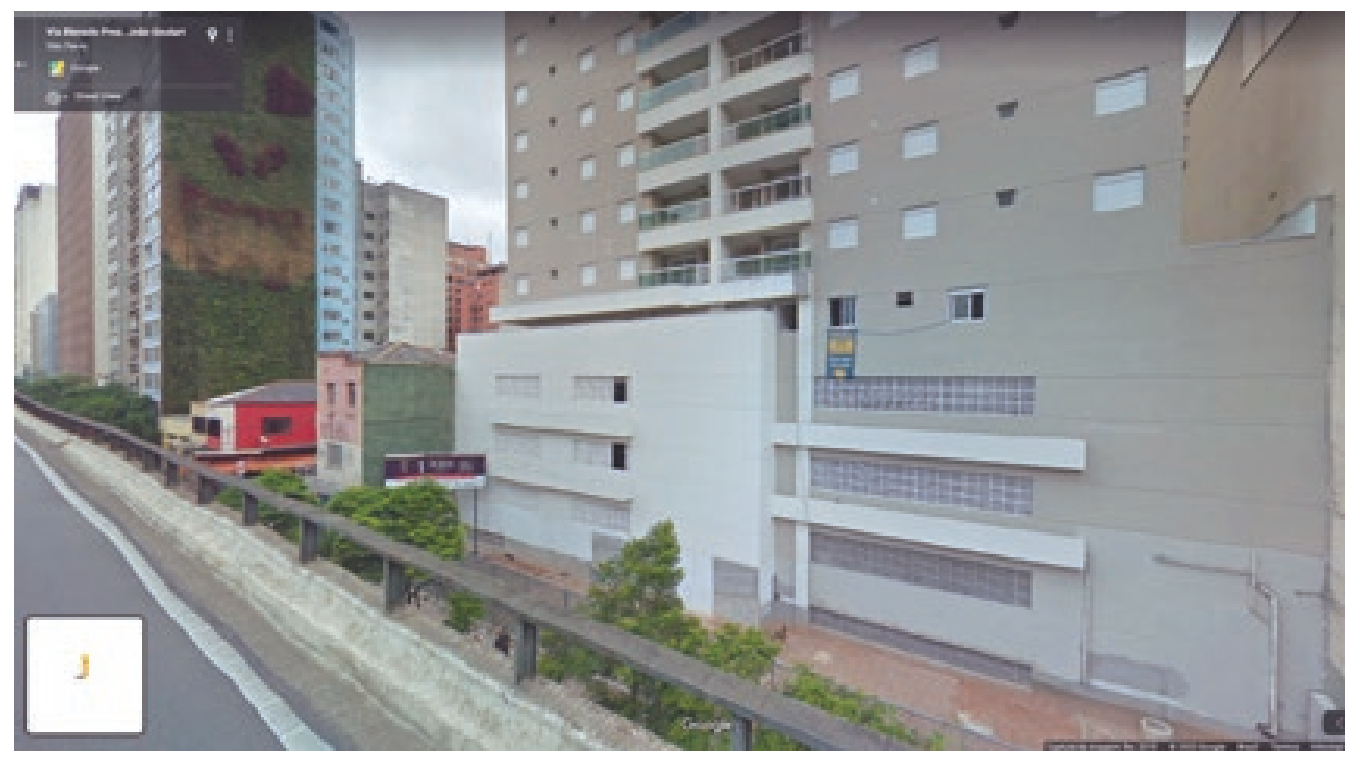

Cyrela S/A ocupa a posição 5, a mais alta posição das empresas que aqui realizaram lançamentos.

Os três empreendimentos ofertam unidades entre os $30 \mathrm{~m}^{2}$ e os

Fig. 3.2.10

Fotografia do Empreendimento Helbor Trend Higienópolis. Google Streetview, 2019. $60 \mathrm{~m}^{2}$ entre o tipo studio, um ou dois dormitórios, sendo que aqueles no entorno do Minhocão lançaram apenas unidades tipo studio ou de apenas um dormitório. Chama a atenção nas unidades a proporção das varandas com relação a área fechada (fig. 3.2.8), os três apresentam grande número de unidades por lançamento, variando entre 220 e 380 unidades, todos com mais de 10 unidades por andar em uma única torre. No embasamento, os três, localizados junto a avenidas e ao lado de corredores de transporte público (Av. Santo Amaro, Av. Gen. Olímpio da SIlveira e Av. São João), se destacam na paisagem por apresentar garagem acima do nível da rua, ocupando a maior parte do terreno e a torre sobreposta à mesma. Portanto se apresentam junto ao passeio público com altos muros cegos, afastando as unidades residenciais do chão da cidade. No caso dos dois empreendimentos junto ao Minhocão, essa elevação do nível térreo, acima das garagens, permite que todas as unidades fiquem acima do tabuleiro do Elevado. Neste térreo elevado, todos os empreendimento implantam piscinas e equipamentos condominiais. 
No caso do Cosmopolitan Santa Cecília (fig. 3.2.9), posicionado a uma distância muito próxima do Elevado e no menor terreno dos três lançamentos, a garagem aflora, além do térreo, três andares, apresentando-se como um paredão até mesmo na cota do Elevado. Ainda devemos destacar que este empreendimento foi lançado em 2015 em um terreno demarcado como ZEIS-3 no PDE de 2014, porém sem se enquadrar como habitação de interesse social (preços acima dos R $\$ 350$ mil). Acreditamos que o mesmo tenha sido permitido pelo direito de protocolo, ou seja por ter dado entrada no pedido de aprovação do projeto junto à prefeitura antes de promulgação do novo Plano.

\section{Linha Helbor Trend - Helbor Empreendimentos S/A Helbor Trend Higienópolis (2014)}

A linha Helbor Trend apresenta, no cadastro da Embraesp, 4 empreendimentos ${ }^{96}$ realizados pela Helbor Empreendimentos S/A. Esta incorporadora, cujo capital foi aberto em 2008, é uma das três empresas listadas na bolsa de valores (BOVESPA) que produziram no entorno do Minhocão na década de 2010. Atualmente, a empresa ocupa a posição 14 do ranking de incorporadoras da Embraesp.

Os três empreendimentos aos quais tivemos acesso no site da incorporadora ${ }^{97}$ também trabalham com garagem acima do nível da calçada, com um leque de equipamentos condominiais presentes em todos eles (salão de festas, salão de jogos, academia, sauna, piscina e área com churrasqueira). No caso do Helbor Trend Higienópolis, isso contribui, assim como na linha Cosmopolitan da MAC, para elevar as unidades residenciais sobre a cota do Minhocão, conforme vemos na imagem feita sobre o tabuleiro do Elevado (fig 3.2.10.). A linha Trend trabalha

\footnotetext{
96. São eles: Helbor Trend Jardins (Bela Vista/2007), Helbor Trend Pacaembu (Higienópolis/2008), Helbor Trend SP (Cambuci/2013), Helbor Trend Higienópolis (Vila Buarque/2014). Além destes listados na Embraesp no site da incorporadora, figura o Helbor Trend Vila da Serra (Belo Horizonte/MG).

97. São eles: Helbor Trend SP, Helbor Trend Higienópolis, Helbor Trend Vila da Serra.
} 

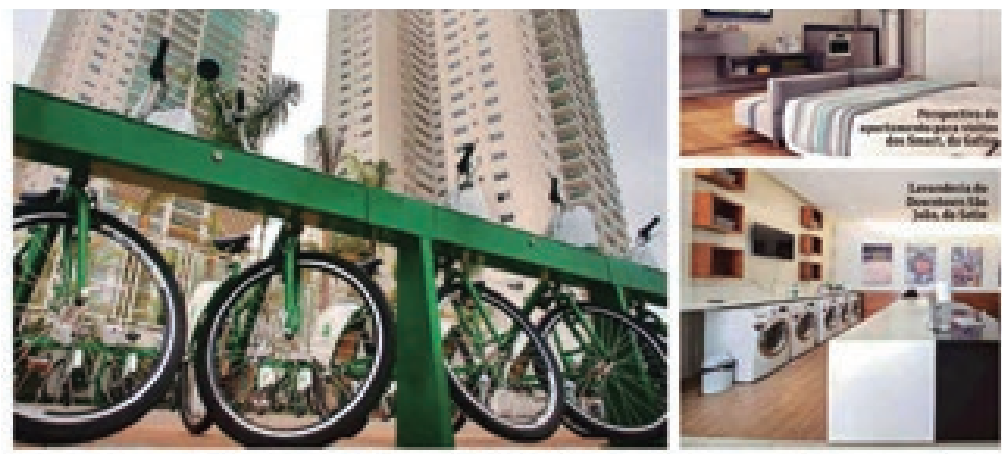

Fig. 3.2.11

Notícia "Van e horta entram na conta do condimínio" Folha de S. Paulo. Nomura, 2016.

\section{VAN E HORTA ENTRAM NA CONTA DO CONDOMÍNIO}

Imperendinentos com servicos compart lhados sko bendincia inevitivel em yandes cldades, afirmam especialistas
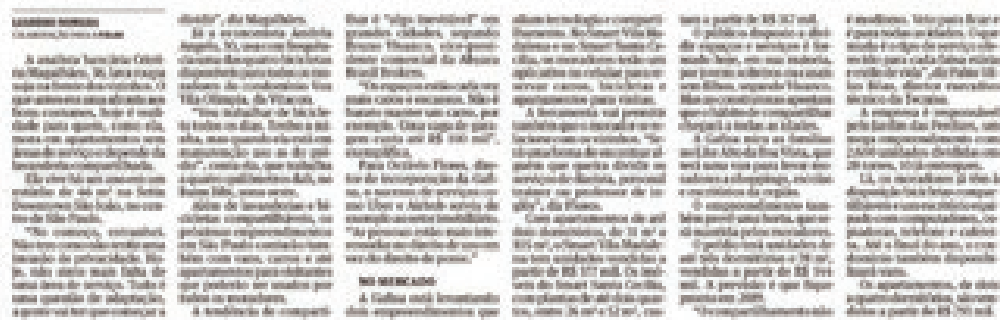

com um leque maior de unidades, variando de empreendimento para empreendimento, com unidades de um a três dormitórios, no caso em questão são ofertadas unidades com um ou dois dormitórios que vão dos $40 \mathrm{~m}^{2}$ aos $52 \mathrm{~m}^{2}$. O empreendimento também oferece unidades tipo "garden" localizadas no térreo elevado; unidades que se apropriam de áreas externas neste térreo para aumentar a sua área de venda, que sobe para, aproximadamente, $90 \mathrm{~m}^{2}$, incluindo o jardim externo.

\section{A linha Smart - Gafisa S/A Smart Santa Cecília (2015)}

A linha Smart da Gafisa apresenta dois lançamentos, ambos realizados no ano de 2015: Smart Santa Cecília e Smart Vila Madalena. A Gafisa também é uma das 3 incorporadoras com capital aberto na bolsa de valores, neste caso no ano de 2006, e uma das mais antigas aqui listadas, com fundação realizada no ano de 1954. A Gafisa se encontra hoje na posição 10 do ranking de incorporadoras da Embraesp. 
Fig. 3.2.12

Captura de vídeo de divulgação do empreendimento Smart Santa Cecília. Gafisa, s/d.

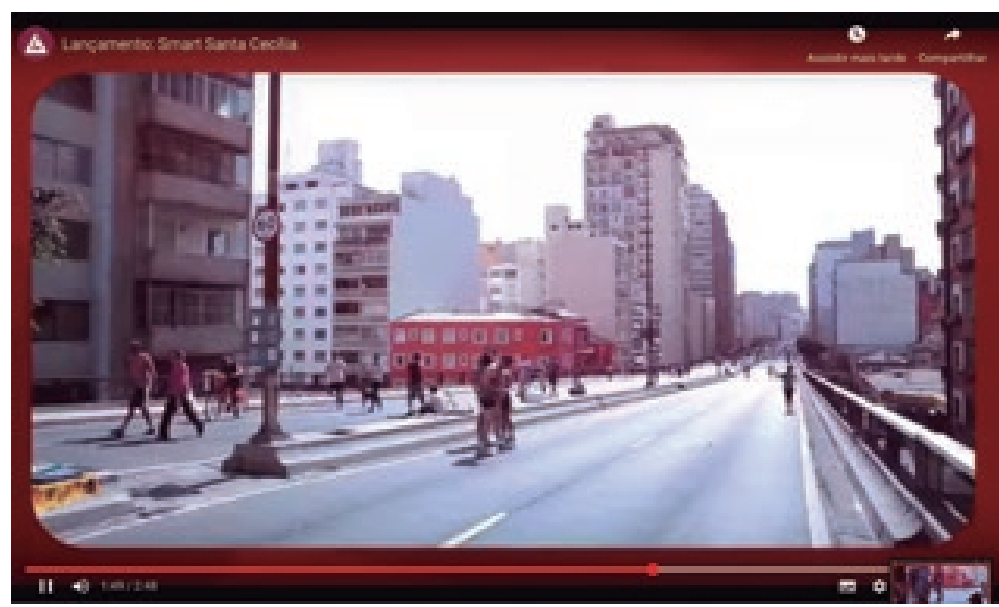

No vídeo publicitário do Smart Santa Cecília, veicula-se este empreendimento como o primeiro "Home and Share" do país, ao incorporar no condomínio serviços de uso compartilhado pagos sob demanda ("pay per use"). Segundo depoimento do vice-presidente da Abyara Brasil Brokers, Bruno Vivanco, em notícia veiculada em 2016 no caderno "Morar" do jornal Folha de S. Paulo" $^{98}$ (fig. 3.2.11), o oferecimento de "serviços compartilhados" trataria-se de uma "tendência inevitável" nas grandes cidades. Este seria um dos diferenciais da linha Smart, que além de oferecer serviços de uso compartilhado, oferece um aplicativo no celular para gerenciar entre os condôminos o uso dos serviços. Cabe aqui reforçar que o acesso a estes serviços se daria mediante pagamento à Gafisa e portanto não se constituem de equipamentos condominiais de propriedade compartilhada entre os condôminos; seu uso depende do pagamento a um terceiro em posição externa ao condomínio. Para explicar este deslocamento, o diretor de incorporação da Gafisa, Octávio Flores, indaga na mesma matéria de jornal que "o sucesso de serviços, como Uber e Airbnb, serviu de exemplo para o setor imobiliário" e afirma que "as pessoas estão mais interessadas no direito de uso em vez do direito de posse". Nesta notícia, além do Smart Santa Cecília também aparece o empreendimento Setin Downtown São João, o Vox Vila Olímpia (Vitacon) e o Like Alto da Boa Vista (Gafisa). No caso do Smart

98. Nomura, Leandro. Van e Horta entram na conta do condomínio. Folha de S. Paulo, 28 de agosto de 2016, caderno "sobre morar", p. 3. 
Santa Cecília, os serviços oferecidos são: locação de bicicleta, carro, espaço de trabalho, salão de eventos, lavanderia e um apartamento para ser alugado "para visitas"; muitos destes já oferecidos com certa frequência em outros lançamentos sem necessariamente se cobrar pelo seu uso.

Os lançamentos da linha Smart ofertam unidades com um ou dois dormitórios, ambos próximos às estações de metrô. Segundo Vivanco, na mesma matéria da Folha de S. Paulo, "o público disposto a dividir espaços e serviços é formado hoje, em sua maioria, por jovens solteiros ou casais sem filhos" ${ }^{\prime 9}$. O Smart Santa Cecília é um dos poucos lançamentos a veicular no material publicitário (fig. 3.2.12) imagens do Minhocão, neste caso aberto para os pedestres.

\section{A linha VN - Vitacon Empreendimentos Vn Nova Higienópolis (2017)}

A empresa, fundada em 2009 por Alexandre Lafer, descendente da família de incorporadores Klabin, apresenta um produto e uma estratégia de crescimento que se destacam sobre as demais aqui. No cadastro da Embraesp, podemos contar 20 lançamentos da marca VN da Vitacon, que se distribuem, principalmente, pelas regiões valorizadas da cidade entre o Centro e o quadrante sudoeste da cidade. Lafer, CEO da empresa, a apresenta não como uma empresa comum de construção e venda de unidades habitacionais, e sim como uma startup, "uma empresa de bytes e não de tijolos" como ele próprio anuncia em depoimento no portal online sobre startups "Startse" ${ }^{100}$. Segundo apresentação no próprio site da incorporadora, trata-se de "uma gestora de ativos imobiliários que tem como tese central o conceito de "living as a service"101, declaradamente vinculada aos novos negócios financeiros. Segundo

99. Nomura, Leandro. Van e Horta entram na conta do condomínio. Folha de S. Paulo, 28 de agosto de 2016, caderno "sobre morar", p. 3.

100. Costa, José E. "Somos uma empresa de bytes e não de tijolos", diz Alexandre Frankel, da Vitacon. Startse, 29 de janeiro de 2019 (link para site na bibliografia).

101. Página web da incorporadora Vitacon (link para site na bibliografia). 
Fig. 3.2.13

Imagem de divulgação do empreendimento VN Nova Higienópolis. Vitacon, s/d

Fig. 3.2.14

Divulgação da plataforma Housi da empresa Vitacon. Vitacon, s/d.
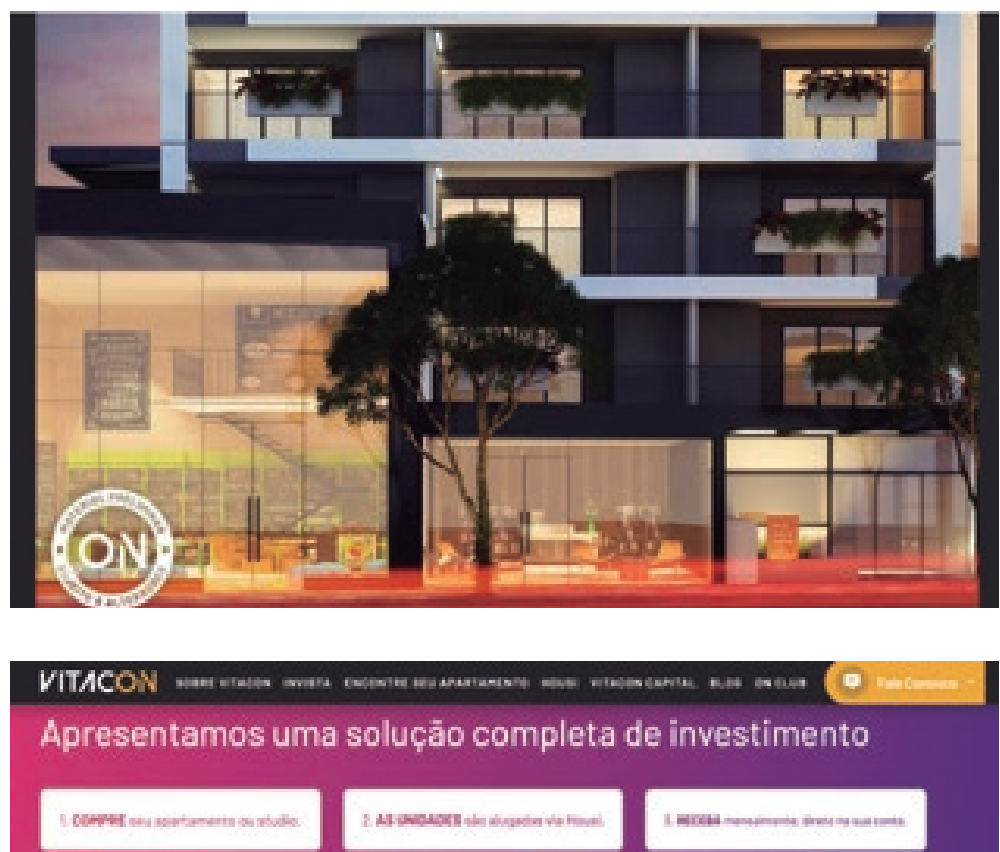

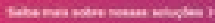

\section{Moradia on demand}

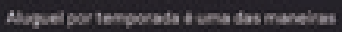

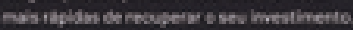

2018

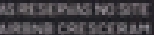

\section{$73 \%$}

Gelower was

we kil mbereots

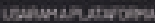

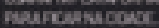

trateresent

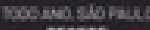

15 MILHÖES

Milliatas

$75 \%$

OOS EVENYos

arecicusopas
$65 \%$

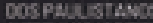

acormoserom

$57 \%$

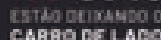

HOUSi

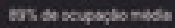

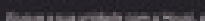

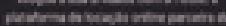

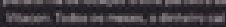

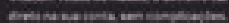

o mesmo site, "os empreendimentos são tratados como serviços e disponibilizados para temporadas de curta, média e longa duração, deslocando a centralidade da produção imobiliária para a sua valorização potencializada por meio da renda imobiliária. Uma vez mais aqui aparece o deslocamento entre direito de posse e direito de uso, atrelado ao pagamento de serviços (rendas).

A produção da Vitacon foca, principalmente, na oferta de unidades tipo studio ou de um dormitório, com menos de $40 \mathrm{~m}^{2}$; 


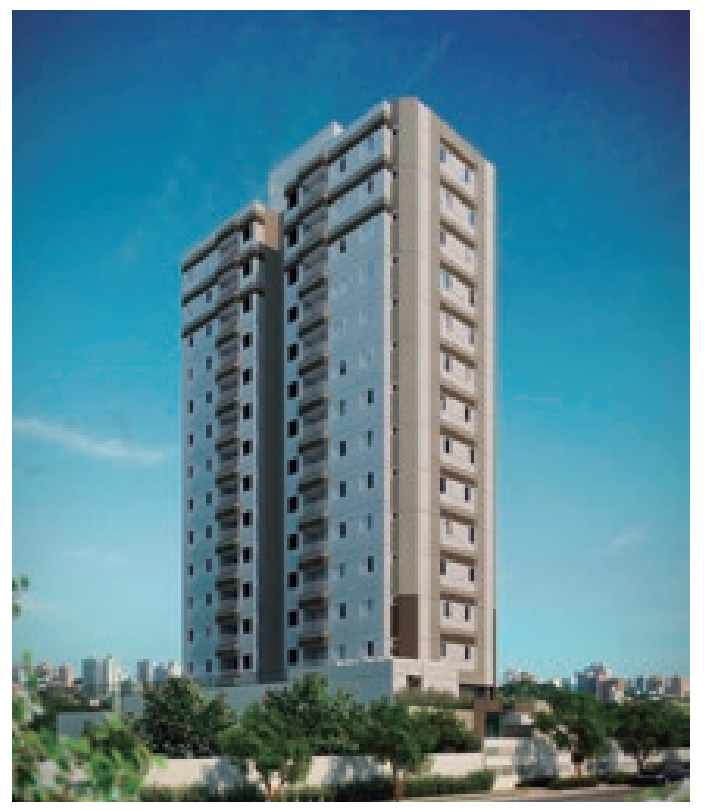

no caso do VN Nova Higienópolis, ele se destaca por oferecer as menores unidades do mercado (e talvez do país), com unidades tipo studio de até $11 \mathrm{~m}^{2}$. Este empreendimento incorpora também novidades do novo Plano Diretor, principalmente no que diz respeito ao incentivo à "fachada ativa" e à desobrigação da construção de áreas de garagem, tratando-se nesta lista do primeiro empreendimento a incorporar estas diretrizes. Verificamos na imagem a seguir (fig. 3.2.13) o térreo do edifício com duas lojas implatadas junto ao alinhamento da rua, situação que diferencia este empreendimentos dos anteriores, caracterizados pela torre isolada no lote ou sobre um embasamento de estacionamento.

A estratégia de marketing é vincular as unidades habitacionais a investimentos que permitem apropriações de rendas imobiliária. Para tal, a empresa também oferece, junto à unidade, uma plataforma online de locação de imóveis por temporada, chamada "Housi" (fig. 3.2.14), que não só oferece imóveis dos clientes da Vitacon mas também de propriedade da empresa, que loca unidades prontas para morar por períodos de até uma diária. Em 2017, a incorporadora fechou uma parceria com o fundo de cingapura Capitaland para investir 1,5 bilhões de reais na incorporação de imóveis voltados unicamente para a locação de unidades, sem
Fig. 3.2.15

Imagem de divulgação do empreendimento Link Residencial Saúde. Vitacon, s/d.

Fig. 3.2.16

Imagem de divulgação do empreendimento On Melo Alves. Vitacon, s/d. 


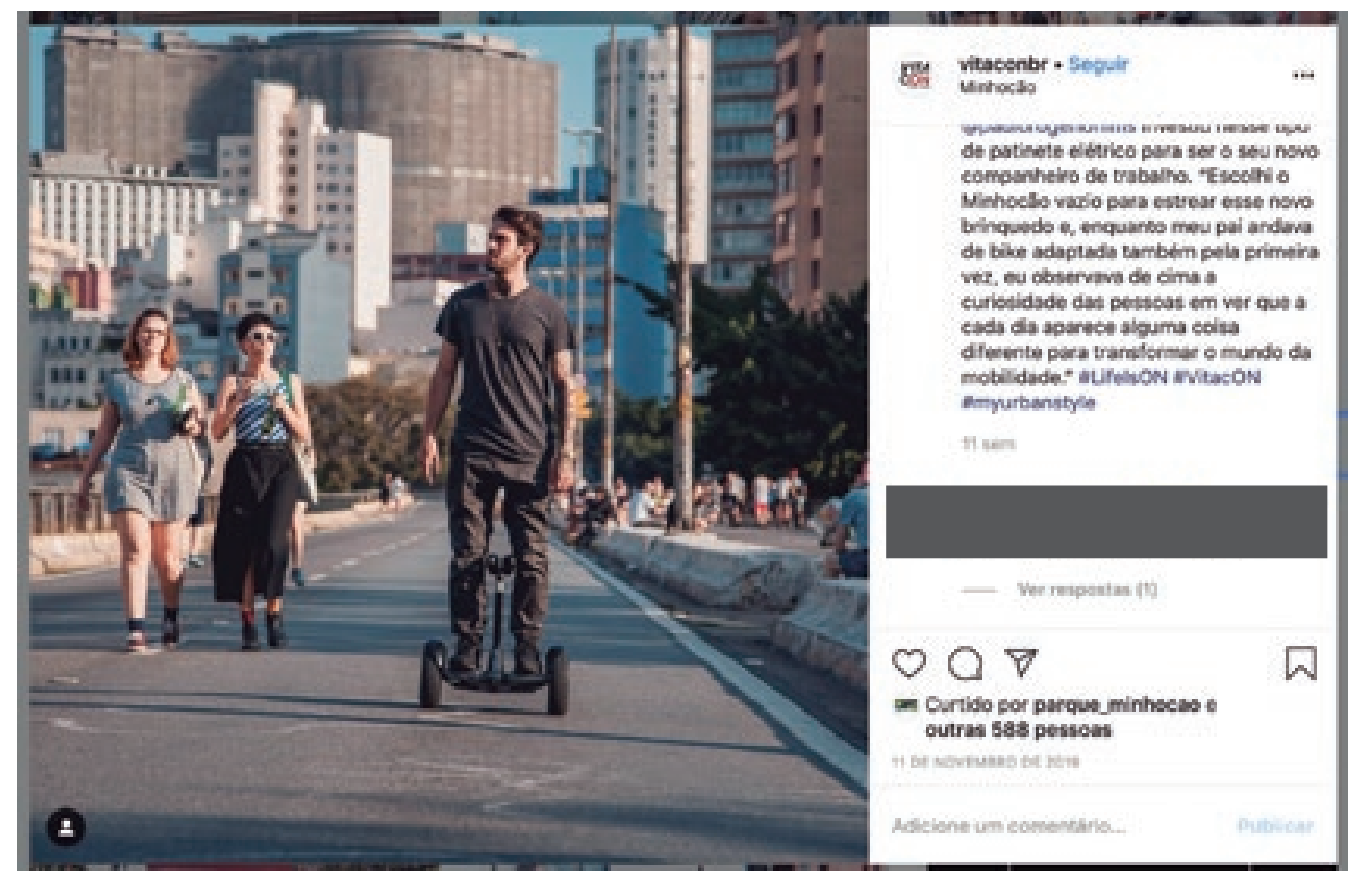

Fig. 3.2.17

Postagem no perfil do Instagram da Vitacon. Instagram, s/d. transferir a propriedade a terceiros ${ }^{102}$. Nesse sentido, a empresa, em 2019, prometeu "transformar os empreendimentos em todos os tipos de produtos financeiros ligados ao mercado imobiliário, como fundos, CRIs e LCIs" ${ }^{103}$. Nesta nova leva de empreendimentos, a Vitacon criou a linha ON, especificamente para compra de unidades que serão disponibilizadas para locação no portal Housi, aproximando-se do antigo mercado dos flats. A empresa ocupa a posição 13 do ranking de incorporadoras da Embraesp, que dado o início recente da sua trajetória destaca a força com que a empresa tem que se posicionado no mercado.

Finalmente, devemos destacar que os empreendimentos da Vitacon foram ganhando sofisticação ao longo dos anos, passando de empreendimentos com componentes padronizados, próximos à média do mercado para apartamento com soluções estruturais mais arrojadas e componentes arquitetônicos singulares (fig.

102. Exame. Construtora Vitacon vai investir R\$ 1,5 bi em parceria com fundo. 19 de novembro de 2019 (link para site na bibliografia).

103.Valor Investe. Vitacon e Easynvest se unem para transformar compactos em fundos. 06 de setembro de 2019 (link para site na bibliografia). 

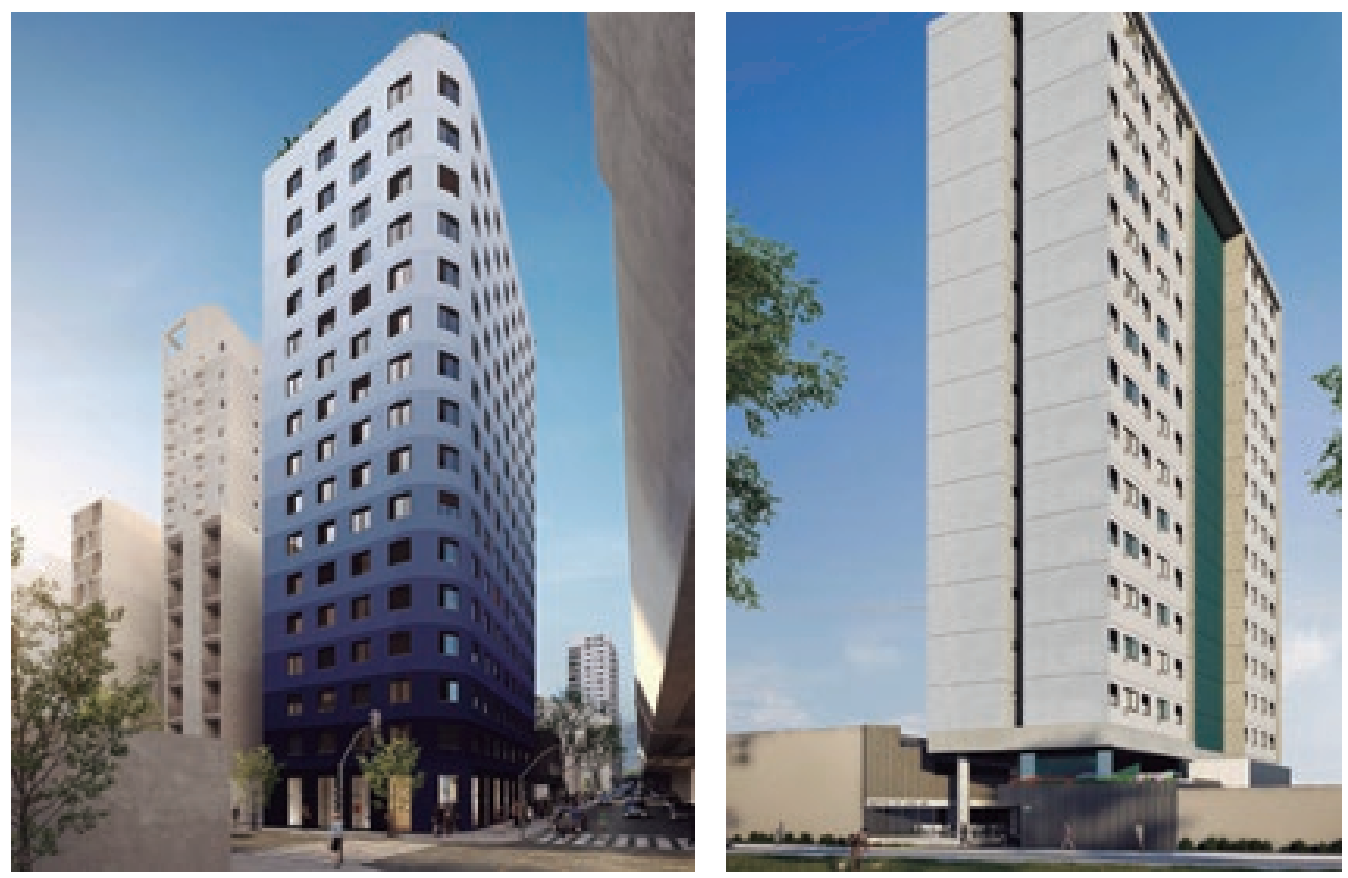

3.2.15 e fig. 3.2.16). Sobre essa incorporadora, vale ainda discutir o seu perfil online na plataforma Instagram. Perfil com mais de 30 mil seguidores que foca, sobretudo, no retrato de pessoas realizando atividades no espaço público, pessoas em momentos de lazer, carregando símbolos de uma nova urbanidade. Vemos em algumas ocasiões imagens de pessoas sobre o Elevado (fig. 3.2.17).

\section{Linha Bem Viver Centro - Magik JC}

Bem Viver Consolação (2017)

A linha Bem Viver da Magik JC tem 5 empreendimentos no cadastro da Embraesp lançados desde 2014, porém no site da incorporadora contamos $11^{104}$ desta mesma linha, alguns deles ainda não lançados. A Magik JC é uma incorporadora fami-

104. São eles: Bem Viver Bela Vista, Bem Viver Marquês de Itu, Bem Viver General Jardim, Bem Viver 9 de julho, Bem Viver Consolação, Bem Viver Frei Caneca, Bem Viver Vila Buarque, Bem Viver Jacuí, Bem Viver Cambuci, Bem Viver Vila Curuçá, Bem Viver Dom Nery. 
Fig. 3.2.20

Imagem de divulgação da unidade do Emp.

Bem Viver General Jardim. Magik JC, s/d.

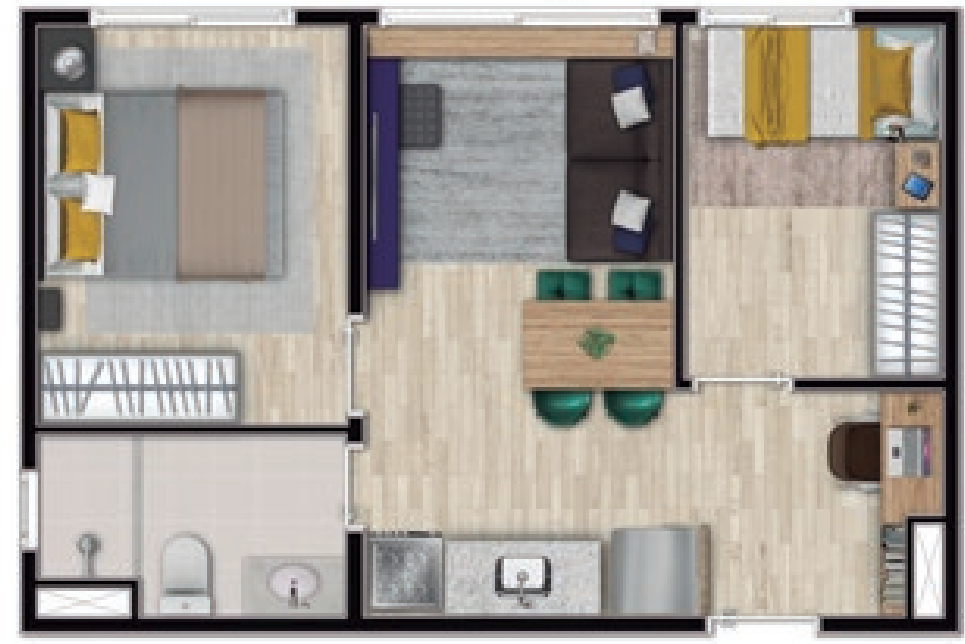

liar, fundada em 1972 com uma trajetória variável de produtos incorporados. Em 2009 ela inicia um processo de parcerias junto a outras grandes incorporadoras, entre elas podemos destacar a Cyrela e a Helbor. Neste sentido, vemos no site da incorporadora que a mesma foi parceira em dois empreendimentos da linha Helbor Trend: o Trend Higienópolis, realizado no entorno do Minhocão e o Trend SP.

A empresa anuncia em todo seu material publicado o certificado "B" de "impacto positivo": uma certificação americana que chancela empresas que "contribuem na solução de problemas sociais e ambientais". No site do Sistema B, a empresa declara contribuir para solucionar o déficit habitacional do país por meio da produção de empreendimentos a preços acessíveis no centro da cidade. Segundo depoimento dado por André Czitrom para este trabalho, diretor da incorporadora e filho do fundador, declara que a certificação "B" ajudou a empresa a se aproximar de parceiros que compartilham da mesma filosofia.

A linha Bem Viver, portanto, realiza empreendimentos para mercado popular com financiamento do Governo Federal do programa Minha Casa Minha Vida, especificamente produz para a faixa HIS 2 (de três a seis salários-mínimos). Se o primeiro empreendimento da linha foi realizado na Vila Curuça (Bem Viver 


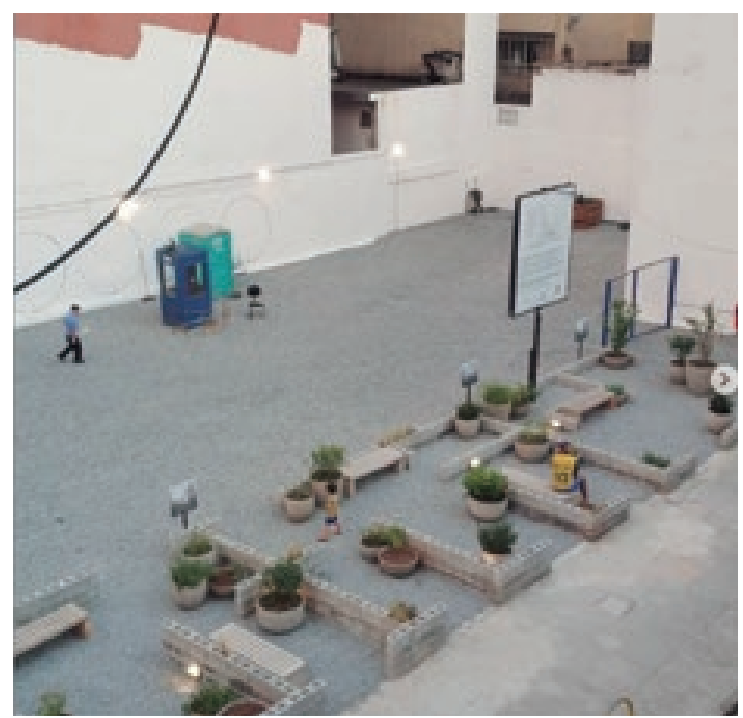

Vila Curuça), no extremo leste da cidade, os empreendimentos seguintes buscaram se aproximar da região central, na qual a incorporadora realiza seus lançamentos atualmente. No entorno do Minhocão, ela é responsável pelo empreendimento Bem Viver Consolação, lançado em 2017 de frente ao Elevado, um dos poucos empreendimentos tão próximos desta estrutura. Fora do cadastro da Embraesp (que vai até 2018) verificamos ainda, no site da incorporadora, o empreendimento Bem Viver General Jardim (fig. 3.2.20) e o Bem Viver Marquês de Itu (fig. 3.2.19), ambos no entorno imediato do Elevado. Esse último também de frente ao Minhocão, com projeto assinado pelo escritório de arquitetura de alto padrão do arq. Isay Weinfeld. Além desses, podemos destacar o empreendimento Bem Viver Major Sertório a apenas $100 \mathrm{~m}$ do Elevado, mas fora da ZEM do Minhocão, portanto dos 11 empreendimentos levantados no site da incorporadora quatro se localizam em regiões muito próximas da estrutura. Outro empreendimento que merece destaque é o Bem Viver 9 de julho, localizado junto ao viaduto da rua Major Quedinho, o que nos faz levantar a hipótese de que a incorporadora procura terrenos relativamente baratos, em locais desvalorizados do Centro, para realizar seus lançamentos

Os empreendimentos da Bem Viver, localizados fora das ZEIS, ofertam unidades tipo studio, com um ou dois dormitórios,
Fig. 3.2.21

Imagem de divulgação do stand de vendas do Emp. Bem Viver Marquês de Itu. Instagram, 2020.

Fig. 3.2.22

Imagem de divulgação do stand de vendas do Emp. Bem Viver Marquês de Itu. Instagram, 2020. 
que giram em torno, na maioria das vezes, de $30 \mathrm{~m}^{2}$ e $40 \mathrm{~m}^{2}$. À medida que a incorporadora procura viabilizar as unidades para faixa de renda que se enquadra dentro do padrão HIS 2 (de três a seis salários-mínimos), os custos de construção são minuciosamente controlados para não superar um certo teto. Consequentemente a planta das unidades resulta numa grande compacidade (fig. 3.2.18): sem varanda, baixa área de circulação e apenas um banheiro. Devemos destacar ainda que nos últimos empreendimentos a incorporadora procura se associar a escritórios de arquitetura com certo reconhecimento no meio arquitetônico, além de também se valer dos incentivos da fachada ativa para incorporar no térreo espaços comerciais voltados para a rua.

Utilizando estratégias de marketing próprias, bastante diferente das outras incorporadoras, a Magik JC procura associar-se a entidades próximas à cultura e educação para promover atividades que aproximam o negócio imobiliário à população, principalmente do entorno. Podemos citar aqui exemplos, como oficina de jardinagem, compostagem, sustentabilidade e bazar de produtos produzidos por "refugiados". Procura também transformar os terrenos antes da construção em espaços de recreação, incorporando a ideia da praça, de estar, para dentro do próprio stand de vendas, espaços que passam a ser palco das atividades culturais acima referidas, além de abrigar rodas de conversas com pesquisadores na área do urbanismo. A seguir, a título de ilustração verificamos a última área de vendas da incorporadora junto ao Elevado no terreno que abrigará o empreendimento Bem Viver Marquês de Itu (fig. 3.2.21 e 3.2.22), vemos uma praça simples e uma placa que anuncia "esta praça é para você", criando um clima de positividade em torno do empreendimento associado ao lazer e à recreação.

Finalmente, sobre a relação da Magik com as rendas imobiliárias, cabe dizer que Czitrom, durante a entrevista, declarou que está avançando com a ideia da locação social independentemente da tramitação de uma lei específica para regulamentar a ideia. Ele declara que justamente o selo Empresa " $\mathrm{B}$ " contribuiu para aproximar a Magik de um conjunto de outras empresas "B" as- 
sociadas a negócios financeiros que estão assessorando o empresário na estruturação deste negócio. Ele cita especificamente a securitizadora Gaia e a Dínamo, consultoria voltada a start ups, empresas que também participaram da estruturação da empresa Vivenda ${ }^{105}$. A Magik JC se encontra na posição 43 do ranking da Embraesp.

\section{Linha Living - Living Incorporação Living For Consolação (2018)}

Por último, verificamos na região do entorno do Minhocão, um imóvel da linha Living, da incorporadora com o mesmo nome, que se soma a outros 22 empreendimentos presentes no cadastro da Embraesp. Espalhados pela região metropolitana, é uma das linhas aqui listadas que mais lançou unidades fora da cidade de São Paulo com grandes empreendimentos localizados em Osasco (753 unidades) e São Bernardo do Campo (348 unidades). Inicialmente, uma marca da Cyrela, criada em 2006, em 2009 a Living ganhou gestão independente, como uma empresa separada, voltada para a produção de unidades na escala nacional focada no "segmento econômico" (Fix, 2011, p.151). Devemos destacar que se inicialmente a Living foi criada com foco no segmento dito econômico, a partir de 2012, ele deixaria de produzir empreendimentos no programa Minha Casa Minha Vida para produzir unidades voltadas para a classe média-alta, de até $\mathrm{R} \$ 700 \mathrm{mil}^{106}$. Na placa obrigatória junto à construção do empreendimento, quem assina a obra é a Cyrela (fig. 3.2.23), a Living aparece como responsável pela construção, neste sentido a Living também não aparece no ranking de incorporadoras da Embraesp ${ }^{107}$.

105. Pamplona, Patrícia; Brant, Danielle. A Vivenda é uma empresa de reforma voltada para o público de baixa renda que em 2018 captou $R \$ 5$ milhões na emissão de debêntures de "impacto social". Folha de S. Paulo, 26 de março de 2018 (link para site na bibliografia).

106. Época Negócios. Cyrela cria nova marca para voltar ao Minha Casa Minha Vida após 6 anos. 28 de setembro de 2018 (link para incorporadora no site).

107. Acreditamos que os lançamentos da Living estejam computados junto aos da Cyrela. 

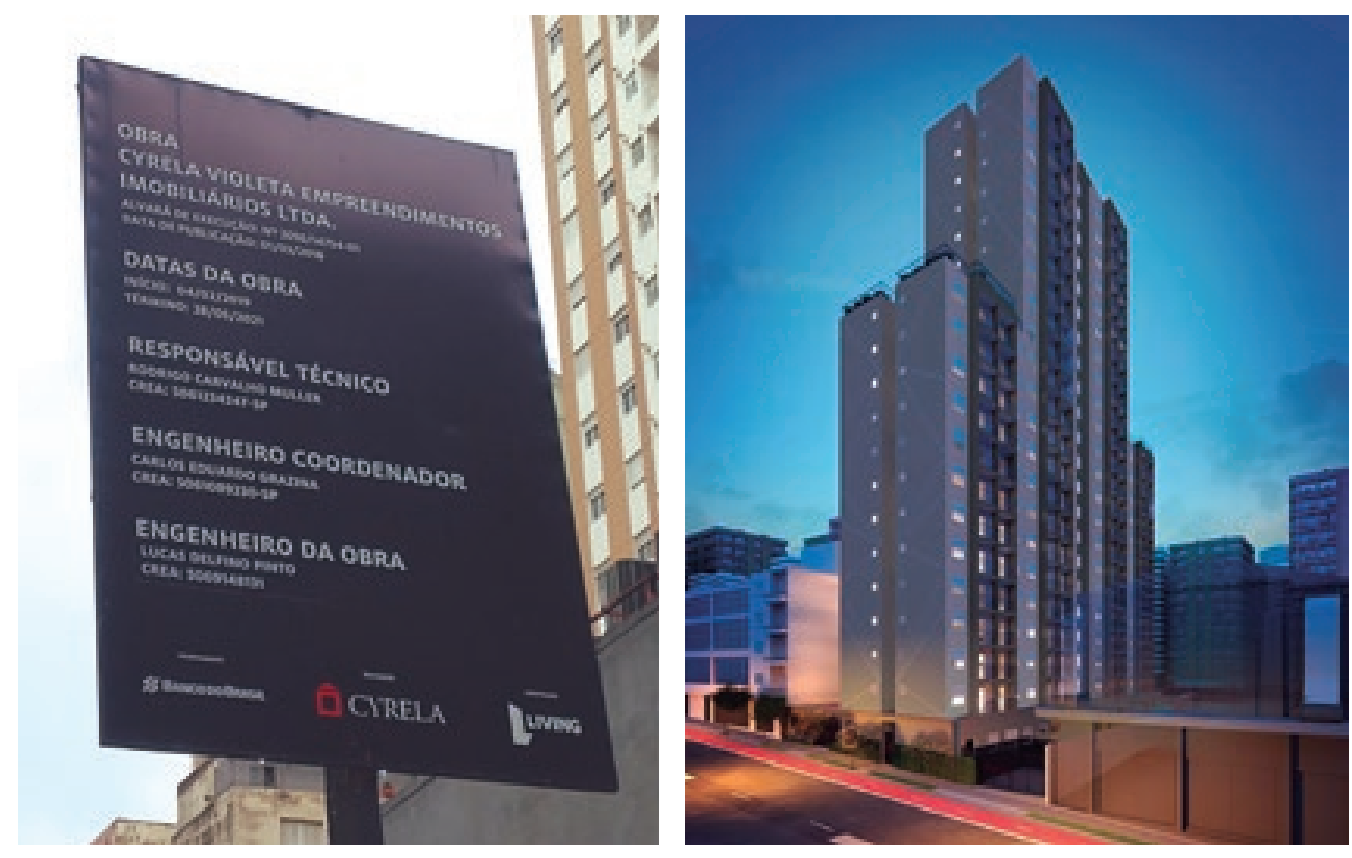

Fig. 3.2.23

Fotografia placa de obras Emp. Living for Consolação. Foto do autor, 2019.

Fig. 3.2.24

Imagem de divulgação do empreendimento Living for Consolação. Living, s/d.
Quase todos os empreendimentos realizados em São Paulo nesta linha apresentam unidades de dois a três dormitórios com ao menos uma vaga. No caso do Living For Consolação (2018), são oferecidas unidades de apenas um dormitório, de $28 \mathrm{~m}^{2}$, sem lavanderia e nem vaga de garagem, o único presente no cadastrado na Embraesp desta linha com essas características. Do ponto de vista da implantação, o empreendimento não tira proveito de incentivos do novo PDE, implantado no alinhamento do terreno, porém sem comércio no térreo (fig. 3.2.24). As áreas condominiais foram também enxugadas, o condomínio oferece apenas um grande bicicletário, salão de festas e lavanderia coletiva; até mesmo a academia foi suprimida, recorrente na maioria dos empreendimentos para a classe média, média-alta.

\section{Share Student Living - Mitre Realty Share Student Living Consolação (2019)}

Além dos empreendimentos até aqui analisados, no sentido de discutir a intensificação da produção imobiliária associada à captação de rendas imobiliárias, destacamos ainda o Share Stu- 
dent Living Consolação, incorporado pela Mitre Realty. Trata-se também de um edifício para moradia estudantil, assim como o 433, mas produzido por outra empresa especializada na produção de residências estudantis, a Share Student Living ${ }^{108}$. A Share surge de uma joint venture do Grupo Mitre, com 58 anos de experiência no setor da incorporação, com a Redstone Residential, "operadora de residências estudantis presente em diversos estados dos EUA e Canadá" ${ }^{109}$. Juntos lançaram um Fundo de Investimento em Participações (FIP) que em 2019 captou 214 milhões de reais para a produção de moradia estudantil ${ }^{110}$. No site da empresa, contamos três empreendimentos; além do Consolação, um no bairro Butantã e outro na Vila Mariana, todos na cidade de São Paulo, sendo que apenas o Consolação está em funcionamento.

Localizado ao lado da Universidade Mackenzie ${ }^{111}$, o Share Consolação, inaugurado em 2018 em um empreendimento construído para este fim, oferece camas compartilhadas em diferentes modalidades com contratos que variam de seis meses e um ano. São seis tipologias de quarto com um valor que vai desde $\mathrm{R} \$$ $1.500 / \mathrm{cama} / \mathrm{mês}$ a R $\$ 4.000 / \mathrm{cama} / \mathrm{mês}$. Aqui, listamos duas tipologias a título de exemplo para ilustrar essa variedade. Na primeira tipologia (fig. 3.2.25), no valor de $\mathrm{R} \$ 2.200,00 / \mathrm{cama} / \mathrm{mês,}$ são oferecidas duas camas em uma única unidade habitacional compartilhada entre duas pessoas, que inclui além do dormitório, banheiro e uma pequena cozinha. Na segunda (fig. 3.2.26), no valor de $\mathrm{R} \$ 2.800,00$, oferece-se dormitórios separados em suíte para um único estudante que compartilha com outros dois um espaço comum com cozinha e copa. Sobre o edifício, cabe reforçar que nas varandas, áreas comumente não computáveis dos empreendimentos, verificamos o seu fechamento e seu aproveitamento para a instalação de cozinha e copa (fig. 3.2.27). Nos

108. Página web da empresa Share Student Living (link para site na bibliografia).

109. Página web do grupo Mitre Realty sobre a empresa Share Student Living (link para site na bibliografia).

110. Quintão, Chiara. Mitre monta FIP para moradias estudantis. Valor, 13 de maio de 2019 (link para site na bibliografia).

111. Universidade Presbiteriana fundada no bairro da Consolação no final do século XIX. 
Fig. 3.2.25

Imagem de divulgação de unidade do Emp.

Share Student Living Consolação.

Share Student Living, s/d.

Fig. 3.2.26

Imagem de divulgação de unidade do Emp. Share Student Living Consolação.

Share Student Living, $\mathrm{s} / \mathrm{d}$.

\section{Fig. 3.2.27}

Imagem de divulgação de unidade do Emp.

Share Student Living Consolação.

Share Student Living, s/d.
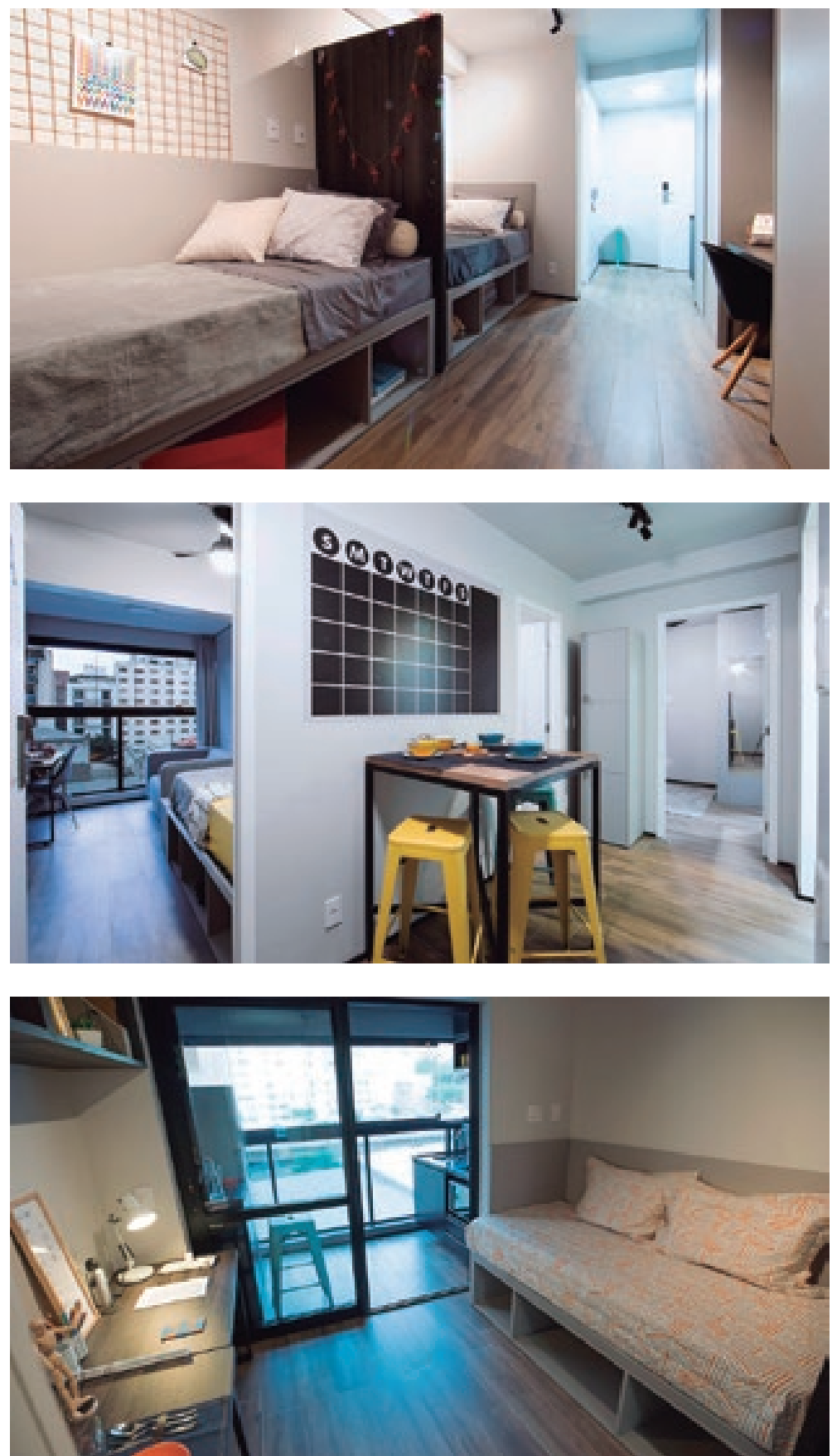
empreendimentos são oferecidos serviços, que incluem espaço de trabalho compartilhado, academia, piscina com churrasqueira, espaço de jogos, lavanderia compartilhada, bicicletas elétricas e serviço de limpeza semanal, alguns deles já incluídos no valor do aluguel. No Instagram da empresa, percebemos a organização de eventos variados para o público estudantil.

A Mitre se encontra na posição 29 do ranking da Embraesp. Devemos destacar que em 2020 a Mitre abriu capital na bolsa de valores por meio de uma IPO que captou R $\$ 1.3$ bilhões se tornando, junto à Cyrela (por meio da Living), MAC, Gafisa e Helbor, a quinta empresa a produzir no entorno do Minhocão, com capital aberto.

Coube neste segundo item do terceiro capítulo discutir a nova produção imobiliária residencial no entorno do MInhocão. Verificamos uma pluralidade de incorporadoras disputando o espaço com diferentes interesses e áreas de atuação: verificamos tanto empresas que estão se especializando na produção de unidades no Centro quanto outras que produzem por toda a metrópole ou majoritariamente nos bairros nobres da cidade. Ainda verificamos certa pluralidade nas estratégias de marketing, ora se aproximando de entidades culturais, ora veiculando novos serviços de uso condominial compartilhado ou apenas realizando ações sobre o Elevado. Na minoria dos casos, o Elevado aparece nos materiais de divulgação dos empreendimentos, às vezes surge de maneira lateral no Instagram da empresa, mas raramente veiculado a um empreendimento específico.

De forma quase unânime, são oferecidas unidades pequenas, entre os studios e unidades de um dormitório. Verificamos que há uma tendência à incorporação de empreendimentos para a locação de unidades com uma diversidade de tipologias habitacionais (residências estudantis, apartamentos minúsculos como os da linha $\mathrm{VN}$, vinculados a hotéis como nos empreendimentos da Setin e no futuro também para locação de interesse social). Da mesma maneira, vemos uma transformação das práticas administrativas das empresas e da composição das suas equipes, muitas se aproximando das práticas associadas às startups, 


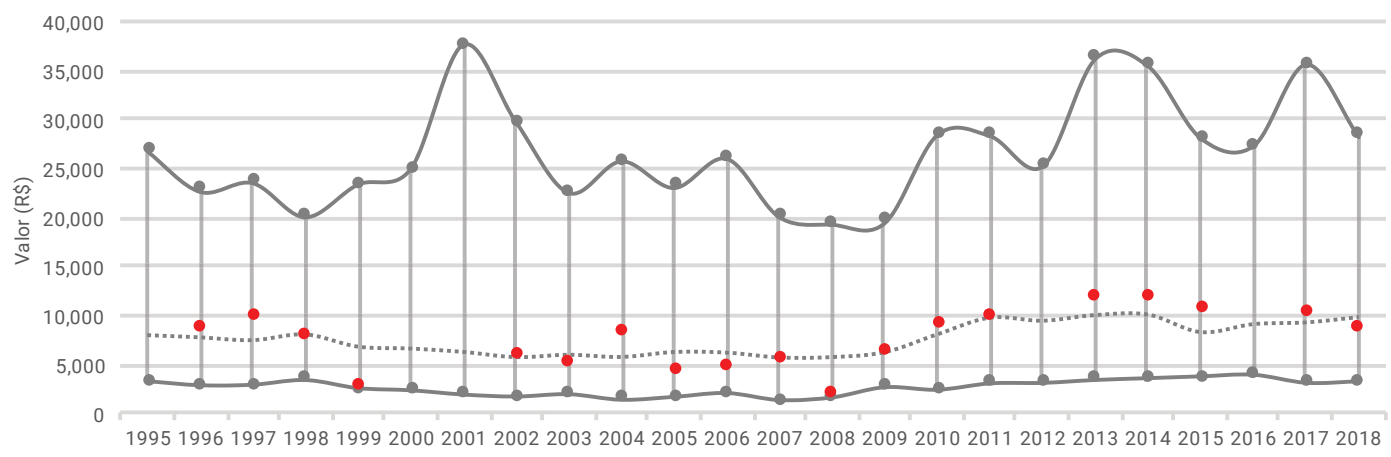

Gráf. 3.2.9

Evolução do preço por $\mathrm{m}^{2}$ de área útil mínima. e máxima. na RMSP e médio na ZEM Minhocão. Embraesp

Mín/Máx RMSP

- Média ZEM Minhocão outras incorporando profissionais oriundos do mercado de capitais. Nesse sentido, verificamos uma importante presença de incorporadoras com capitais abertos na bolsa de valores, junto a outras que pautam a sua valorização na emissão de outros produtos financeiros associados à securitização das rendas imobiliárias. Ao longo destes 10 empreendimentos verificamos também que foram se aproximando do entorno do Minhocão empresas cada vez maiores.

Sobre o preço das unidades lançadas no entorno do Minhocão, no gráfico ao lado (gráf. 3.2.9) verificamos em vermelho o valor por metro quadrado de área útil nas unidades lançadas na ZEM do Minhocão e em preto o valor máximo e o mínimo das unidades lançadas na RMSP com preços atualizados para o ano de 2018. Em pontilhado, vemos a média do preço por metro quadrado de área útil da metrópole. Verificamos que os valores do Minhocão se encontram muito próximos daqueles praticados na média da metrópole, por vezes acima da média e por vezes abaixo. Algumas poucas vezes verificamos que o preço é próximo do mínimo praticado na metrópole, mas nunca vemos que o mesmo se aproxima do máximo. Mais recentemente verificamos uma leve tendência a ficarem por cima da média da metrópole, que nos permite supor que a região está permitindo veicular um produto mais caro, portanto sugerindo o aumento do preço do imobiliário aqui. Sobre o valor dos imóveis, o "Informes 


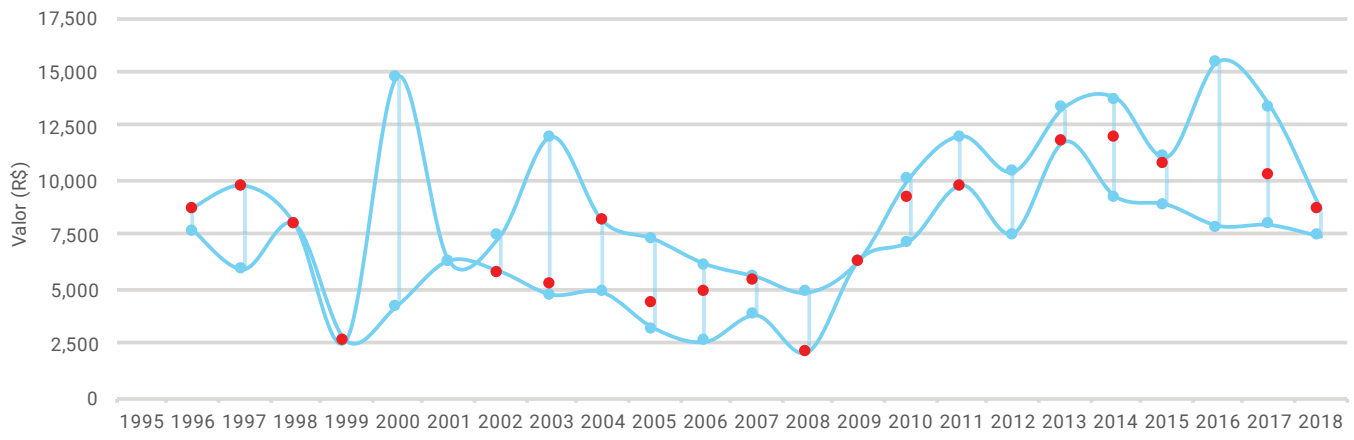

Urbanos" n. 34 divulgado pela Secretaria de Desenvolvimento Urbano (SMDU) da prefeitura esclarece:

\begin{abstract}
Nota-se ainda que a área do apartamento diminui, mas não o preço. Segundo matéria da Folha de S. Paulo, o preço por $\mathrm{m}^{2}$ do imóvel é o mesmo, o tamanho é que encolheu (Folha 05/05/2018). O que se verifica, no entanto, é que ao mesmo tempo em que o tamanho se reduziu os preços tiveram um incremento significativo, em especial a partir de 2009, transformando a Sub Sé desde então em uma das regiões mais caras da cidade para aquisição de imóveis novos (SMDU, 2018, p. 4) ) $^{112}$.
\end{abstract}

\section{Gráf. 3.2.10}

Evolução do preço por $\mathrm{m}^{2}$ de área útil mínimoe máximo nos bairros do entorno e médio na ZEM Minhocão. Embraesp

- Mín/Máx Barrios do entorno

- Média ZEM Minhocão

Na sequência, verificamos o preço da ZEM do Minhocão comparada às Zonas de Valor pelos quais o Elevado cruza (Barra Funda, Santa Cecília e Centro). Nota-se (gráf. 3.2.10) que a distância entre o mínimo e o máximo é menor e que as unidades do Minhocão por vezes estão mais próximas do mínimo e por vezes mais próxima do máximo, não existindo um padrão reconhecível.

Finalmente, analisamos o Valor Geral de Vendas (VGV) dos empreendimentos na ZEM do Minhocão a partir de 1995,

112. Secretaria de Desenvolvimento Urbano da Cidade de São Paulo (SMDU). 0 que está sendo lançado no Centro de São Paulo? Informes Urbanos, São Paulo, n.34, agosto, 2018. 


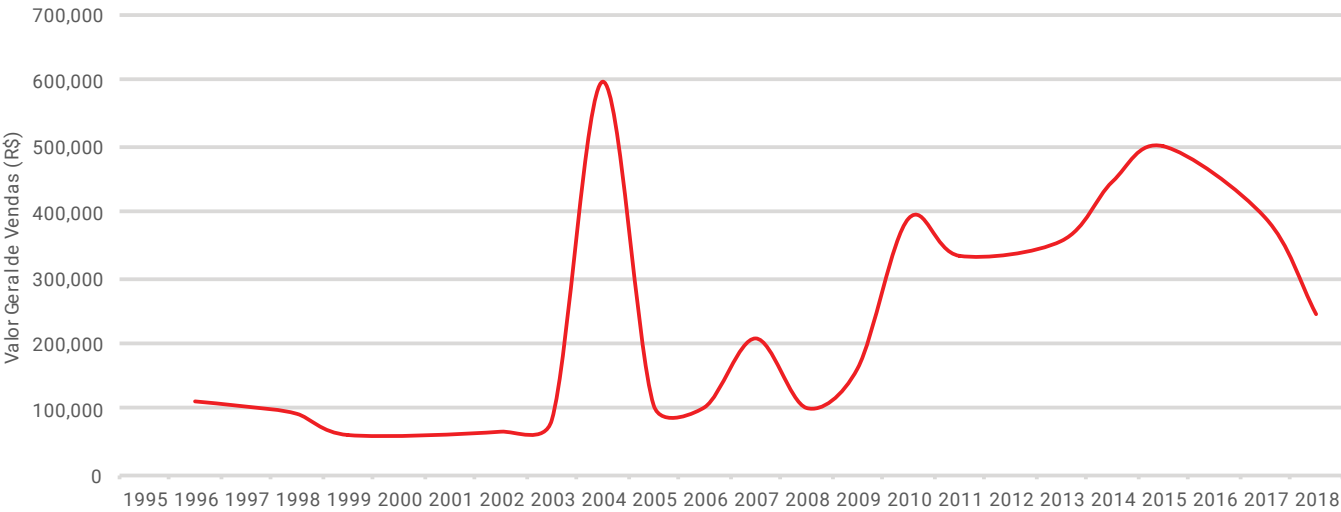

Gráf. 3.2.11

Evolução do VGV dos empreendimentos na ZEM Minhocão (valores atualizados para 2018). Embraesp
pós-Plano Real. Verificamos (gráf. 3.2.11) que a média do VGV no entorno do Minhocão se eleva de forma significativa a partir de 2010; podemos concluir, portanto, que além de um aumento no número de lançamento que vimos no começo deste item há também o aumento do VGV desses empreendimentos, corroborando com a hipótese de que existe aqui uma intensificação da produção em curso. 


\section{3}

\section{Impulsos e limites para a (re)capitalização da propriedade imobiliária: novas e antigas formas de uso do espaço}

\footnotetext{
É o resultado de uma história que deve ser concebida como a atividade de 'agentes' ou 'atores' sociais, de 'sujeitos' coletivos operando por impulsos sucessivos, projetando e modelando de modo descontínuo (relativamente) extensões de espaço. Esses grandes grupos sociais, compreendendo classes e frações de classes, assim como instituições que seu caráter de classe não é suficiente para definir, agem uns com e/ou contra os outros. As qualidades e 'propriedades' do espaço urbano resultam de suas interações, de suas estratégias, seus êxitos e derrotas. (Lefebvre, 1999, p. 117)
}

Neste último item do terceiro capítulo, buscamos traçar um perfil mais amplo da forma como a região do entorno do Minhocão vem sendo transformada, desdobramentos nas formas de consumir o espaço, assim como os limites a este processo de homogeneização e diferenciação. Na primeira parte, discutimos outros impulsos que a propriedade no entorno do Minhocão vem recebendo no sentido de potencializar a valorização da terra por meio da capitalização das rendas imobiliárias, especificamente atrelada aos novos negócios "hipsters". No sentido de mensurar essas transformações, na sequência, nos debruçamos sobre uma análise quantitativa e transversal das transformações da propriedade por meio de mudanças no uso e ocupação do solo nesta porção do território entre o final do século XX e os dias de hoje.

Entendemos até aqui que a região é alvo de um processo de intensificação da produção imobiliária, que tem seus efeitos multiplicados em face de novas formas de se comercializar (o uso da) propriedade, ampliando as possibilidades de projeção e captura de rendas imobiliárias. Produção imobiliária que 
"aguça a contradição entre o uso do espaço como valor de troca, o direito à alienação e o uso do espaço como valor de uso, o direito ao usufruto" (Petrella, 2017, p. 19). Conforme aponta Petrella:

\footnotetext{
Neste processo, a disputa pela valorização e capitalização, a partir de sua privatização, orienta para a reestruturação espacial por meio da renovação urbana, que busca engendrar um novo produto imobiliário, diferenciado, e cujas relações de produção e de reprodução segregam a população existente: uma nova morfologia espacial, meio e resultado da reestruturação dos padrões de acumulação capitalista (Petrella, 2017, p. 266).
}

Recuperando questões do primeiro capítulo, lembramos que a região do entorno do Minhocão passou por um intenso processo de degradação ambiental associado à construção da via expressa elevada, que por sua vez acarretou em um processo imediato de desvalorização dos imóveis posicionados de forma contígua à estrutura. Esta situação possibilitou que esses imóveis fossem ocupados por uma população de baixos ingressos, "uma espécie de periferização do Centro" (Petrella, 2017, p. 19) ou popularização, processo que além de ter se intensificado no entorno do Minhocão, também se verificou em grande parte da região central. Buscamos, portanto, no final deste último item, iluminar este perfil popular da região, espaço de reprodução e socialização das camadas populares.

Ao mesmo tempo, o caráter "desvalorizado" destas regiões abre a possibilidade de uma (re)valorização da propriedade por meio de uma "renovação urbana", enquanto nova "fronteira da lucratividade". Trata-se portanto de uma disputa pelo espaço (produto social): de um lado a resistência à transformação e permanência do seu caráter popular, de outro como plataforma de valorização do capital. Nas palavras de Rufino: "aqui se ilumina uma particularidade da valorização imobiliária, que se constitui como meio de controle social, pois tende a limitar as apropriações possíveis, fragmentar, hierarquizar e homogeneizar usos" (Rufino, 2012 , p. 205). Entendemos que o espaço não é mero recipiente, mas "uma produção social" que nos permite analisar "os con- 
flitos que se estruturam e as lutas que se travam em torno desse ambiente construído socialmente" (Brandão, 2012, p. 65). Cabe na última parte deste item elucidar estes conflitos que até então encontravam-se silenciados.

Iniciamos então com esta outra face do processo de transformação do espaço, que trata do surgimento de novos empreendimentos comerciais e de serviços voltados para um novo público de classe média-alta, que gradativamente passa a circular, consumir e/ou morar no centro. No intuito de articular a discussão específica deste espaço com movimentos mais amplos do capital, nos valemos aqui da descrição de Alcântara (2019), sobre o bairro da Vila Buarque, que associa novos empreendimentos comerciais a uma nova "cena hipster". O autor define este "fenômeno" que ele chama de "hipsterização" da seguinte maneira:

Tal fenômeno, que aqui denomino "hipsterização", é caracterizado por uma crescente atração - tanto para moradia como para lazer e consumo - de jovens adultos urbanos de camadas médias superiores genericamente classificadas como hipsters. O termo se refere a pessoas ligadas a atividades profissionais tidas como "criativas" (tais como comunicação, tecnologia, inovação e artes), majoritariamente alinhadas a um espectro político mais progressista, e que encontram na região central uma infraestrutura, diversidade sociocultural e redes de lazer e sociabilidade que não apenas são importantes para a plena realização de seus estilos de vida, como também não podem ser encontradas em outros bairros da cidade. A pesquisa tem como ponto de partida uma série de novos negócios (tais como restaurantes, bares, livrarias, cafés, lojas de decoração, moda e design) abertos nos últimos anos no bairro e que são voltados a (e foram criados por) pessoas potencialmente classificáveis como hipsters, e que oferecem produtos e ambientes que prometem o alto nível de sofisticação e especialidade buscado por este perfil, que busca produzir formas de distinção por meio da evitação do consumo de massa (Alcântara, 2019, p. 8). 
Gráf. 3.3.1

Número de novos estabelecimentos hipsters na Vila Buarque.

Alcântara, 2019.
30

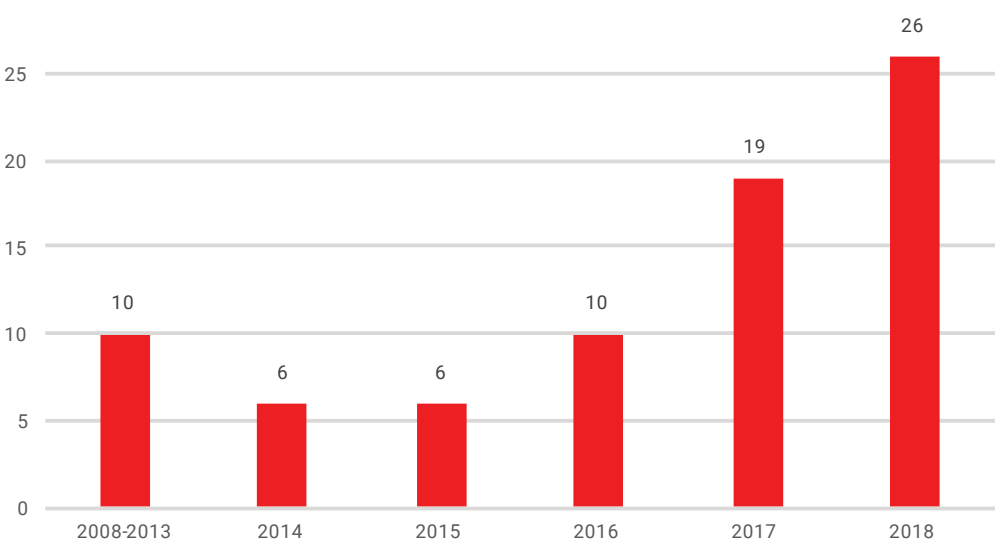

Apesar do autor evitar o enquadramento deste processo, de "hipsterização", enquanto um processo de gentrification ${ }^{113}$, ele próprio aproxima este grupo aos "pioneiros da gentrification"114. Não cabe neste trabalho discutir as diferentes assumpções que o termo gentrification recebeu ao longo do tempo, nem como a sua tradução "gentrificação" é apropriada em termos vulgares ou nos debates teóricos sobre a transformação do espaço. Nos limitamos aqui apenas a analisar outras facetas das transformações no espaço, associadas à ação de pequenos ou médio empresários, "que são ao mesmo tempo produtores e beneficiários desse clima (de certa forma celebratório) das novas experiências vivenciáveis no centro

113. Adoto aqui o termo em inglês, conforme o próprio Alcântara sugere para tratar de "definições analíticas e conceituais disputadas ao longo da ampla bibliografia acerca do tema" (Alcântara, 2019, p. 95) que tratam "de uma epistemologia euroamericana sobre as transformações observadas nas antigas metrópoles industriais do Norte global no pós-fordismo (logo, em contextos muito bem delimitados)" (Alcântara, 2019, p. 74).

114. "Incluem profissionais do mundo da arte, da mídia e outros ramos culturais, acompanhada por uma população considerada pré-profissional, por exemplo, estudantes. Costumam não ser conformistas com o estilo de vida dominante e também com relação a determinados aspectos políticos. A atração que sentem pelas áreas centrais da cidade tem por base sua diversidade cultural e social, e também pelos baixos preços do mercado imobiliário residencial. Apresentam uma diferença importante entre o capital cultural que possuem e o capital econômico de que dispõem: embora o primeiro costume ser importante, já que a maior parte dos pioneiros tem algum tipo de grau universitário, seu capital econômico é muito limitado. Essa diferença se reflete nas moradias reabilitadas com base na decoração e no estilo diferentes daqueles que existiam anteriormente, embora podendo incluir - pelo restauro e realce - elementos construtivos originais, em geral implicando uma solução de baixo investimento de capital" (Martínez-Rigol, 2005, pp. 115-116 apud Alcântara, 2019, p. 69). 


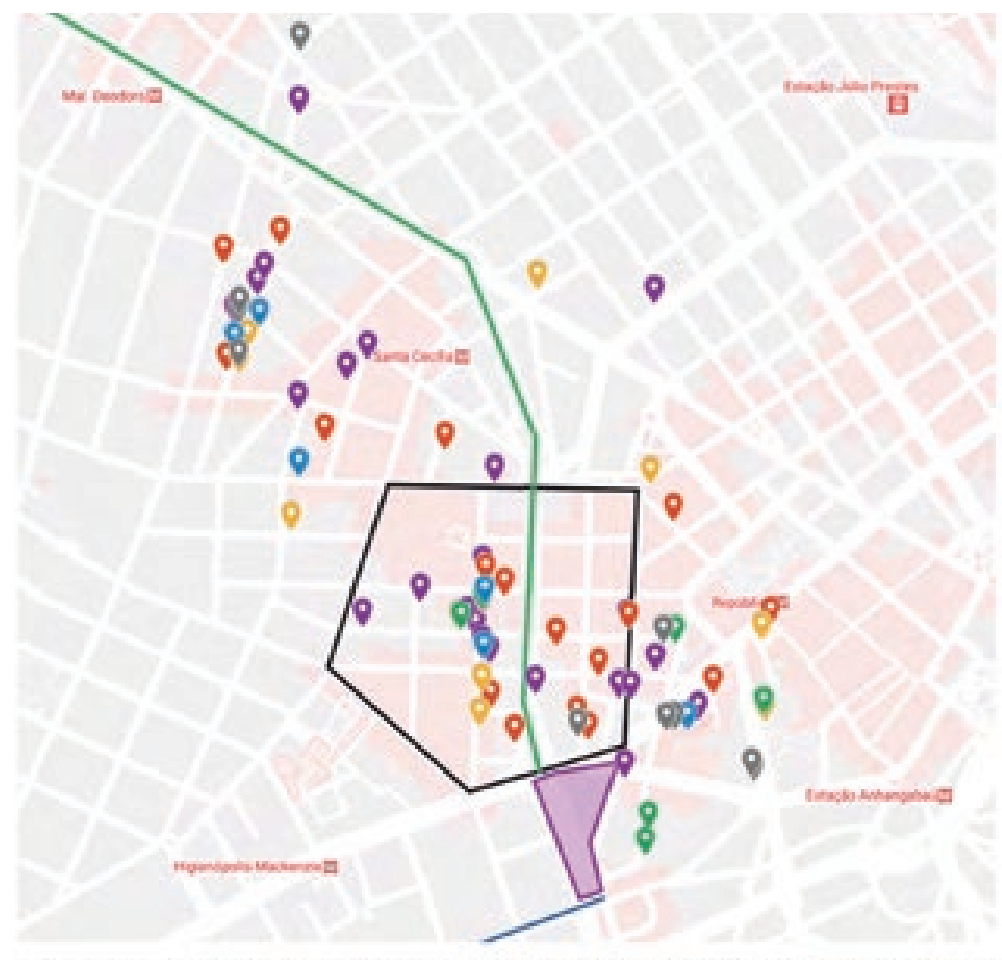

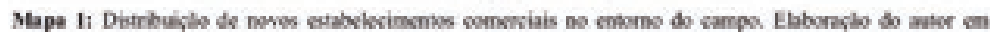
derembeo de 2018. Fonte, Goople Maps (2013)
Fig. 3.3.1

Localização dos empreendimentos hipsters. Alcântara, 2019.

de São Paulo" (Alcântara, 2019, p. 13), ainda, atores econômicos que "beneficiam-se de um privilégio de algum nível de possibilidade de escolha" (Alcântara, 2019, p.13). Queremos dizer com isso que se trata de um público diferente daquele popular que paulatinamente ocupou este espaço nas últimas quatro décadas.

Em levantamento realizado por Alcântara na região da Vila Buarque, o autor aponta uma intensificação no número de "novos estabelecimentos comerciais potencialmente destinados a um público hipster". Podemos observar no gráfico (gráf. 3.3.1) que, se entre 2008 e 2013 foram inaugurados 10 estabelecimentos comerciais com esse perfil, nos cinco anos seguintes (2014-2018) eles somaram 67 novos empreendimentos deste tipo.

No mapa a seguir (fig. 3.3.1), elaborado também por Alcântara (2019), observamos que o Minhocão encontra-se no centro da imagem e se por um lado poucos estabelecimentos se localizam 
imediatamente de frente a ele, por outro eles se realizam em ambas margens do mesmo, superando mais uma vez a ideia de que o Minhocão seria uma barreira para o desenvolvimento destas atividades econômicas. A territorialização dos novos estabelecimentos voltados para este público com alto poder aquisitivo nos mostra que esta região, pouco explorada em um passado próximo ou até mesmo evitada, vive um clima de certa efervescência comercial, que podemos relacionar ao deslocamento de um novo público consumidor. Região em que podemos verificar também, com base no item anterior, o surgimento de novos lançamentos residenciais a partir da virada do século XXI e principalmente a partir da promulgação do último PDE (2014).

Se por um lado o autor evita estabelecer relações de causalidade de cunho "estruturalista" entre novos lançamentos imobiliários, estabelecimentos comerciais e um novo público de alto poder aquisitivo, nos parece que existe uma relação simbiótica entre estas partes. Segundo a matéria publicada no jornal Folha de S. Paulo, intitulada "Novos negócios hipster valorizam imóveis do centro de São Paulo", "bares, restaurantes e espaços culturais" seriam "frequentemente citados nos materiais publicitários que anunciam os novos empreendimentos da região, que se valem de um apelo jovem e descolado, recorrendo com frequência a grafites, decoração moderna e referências a bicicletas"115. O artigo de jornal, portanto, declara que existe, sim, um novo público, atraído pelos estabelecimentos, que também está representado nos anúncios publicitários dos empreendimentos da região e portanto constituem o público-alvo de ambos negócios.

Nesse sentido, Kalichman (2019) ao analisar o material publicitário e os apartamentos decorados nos estandes de venda de lançamentos imobiliários da região central verifica uma presença quase contínua de elementos decorativos de "estilo industrial". Presença que podemos associar a "novas formas de consumo, lazer e sociabilidade de grupos que promovem uma mediação cosmopolita entre os modos de vida locais e referências estéticas

115. Lacerda, Fernanda. Novos negócios hipster valorizam imóveis do centro de São Paulo. Folha de S. Paulo, 27 de novembro de 2019 (link para site na bibliografia). 
de grandes cidades globais" (Kalichman, 2019, p.103). A autora levanta que as transformações recentes na cidade de Nova Iorque, especificamente relacionadas aos bairros industriais como Soho ${ }^{116}$ ou Chelsea, são umas das referências principais na construção destes símbolos ${ }^{117}$. Confome ela aponta, "esse modelo de transformação urbana, ao viajar o mundo, levou consigo uma estética que o faz reconhecível e familiar aos iniciados em certos gostos e padrões de consumo, que por sua vez parecem formar o público-alvo dessa "volta à cidade"(Kalichman, 2019, p.101). Neste sentido, podemos também vincular o próprio Highline como um importante símbolo deste deslocamento, que inclui a promessa de capitalização de um antigo espaço industrial para a construção de um novo paradigma urbano cosmopolita.

O "mapeamento afetivo" (fig. 3.3.2) divulgado pela incorporadora Magik JC contribui para ilustrar a relação simbiótica entre lançamentos imobiliários e novos estabelecimentos comerciais. Resultante de uma oficina organizada pelo grupo Acupuntura Urbana em parceria com a incorporadora, o mapa trata da interseção do bairro da Vila Buarque com o da República posicionando o Minhocão no centro da imagem. Na descrição da atividade que originou este mapa, declara-se "levantar e ilustrar os pontos de interesse culturais (SIC) sociais e históricos, ressaltando o lado afetivo e o senso comunitário, que às vezes podem parecer inexistentes nos dias de hoje"118. No mapa, verificamos

116. A transformação do bairro industrial de Nova lorque Soho associadas à conversão de antigos galpões industriais em lofts inicialmente ocupados pela classe de artistas (pioneiros da gentrification) cunhou o termo Soho Effect.

117. Sobre as transformações na cidade de Nova Iorque, a autora Zukin escreve: "Em alguns bairros, artistas, atores, programadores de softwares de computador, e músicos (...) estão se divertindo em cafés na calçada, comendo brunch às 2 da tarde e saindo à meia-noite para espaços para performances em galpões e bares de música. Em outras áreas da cidade, editores, professores universitários, advogados e escritores estão empurrando carrinhos de bebê, falando em celulares e fazendo compras em pequenas lojas de design. (...) Nas áreas onde os hipsters e gentrifiers vivem, há um novo cosmopolitismo no ar: tolerante, descolado, casual. E isso não é ruim. Mas, aos poucos, os velhos bairros étnicos para onde eles se mudaram estão morrendo. (...) As pessoas que pareciam tão enraizadas nestes bairros estão desaparecendo" (ZUKIN, 2011: p. 7, apud Alcântara, 2019: p. 70).

118. Página web da organização Acupuntura Urbana sobre a atividade Mapeamento afetivo (link para site na bibliografia). 


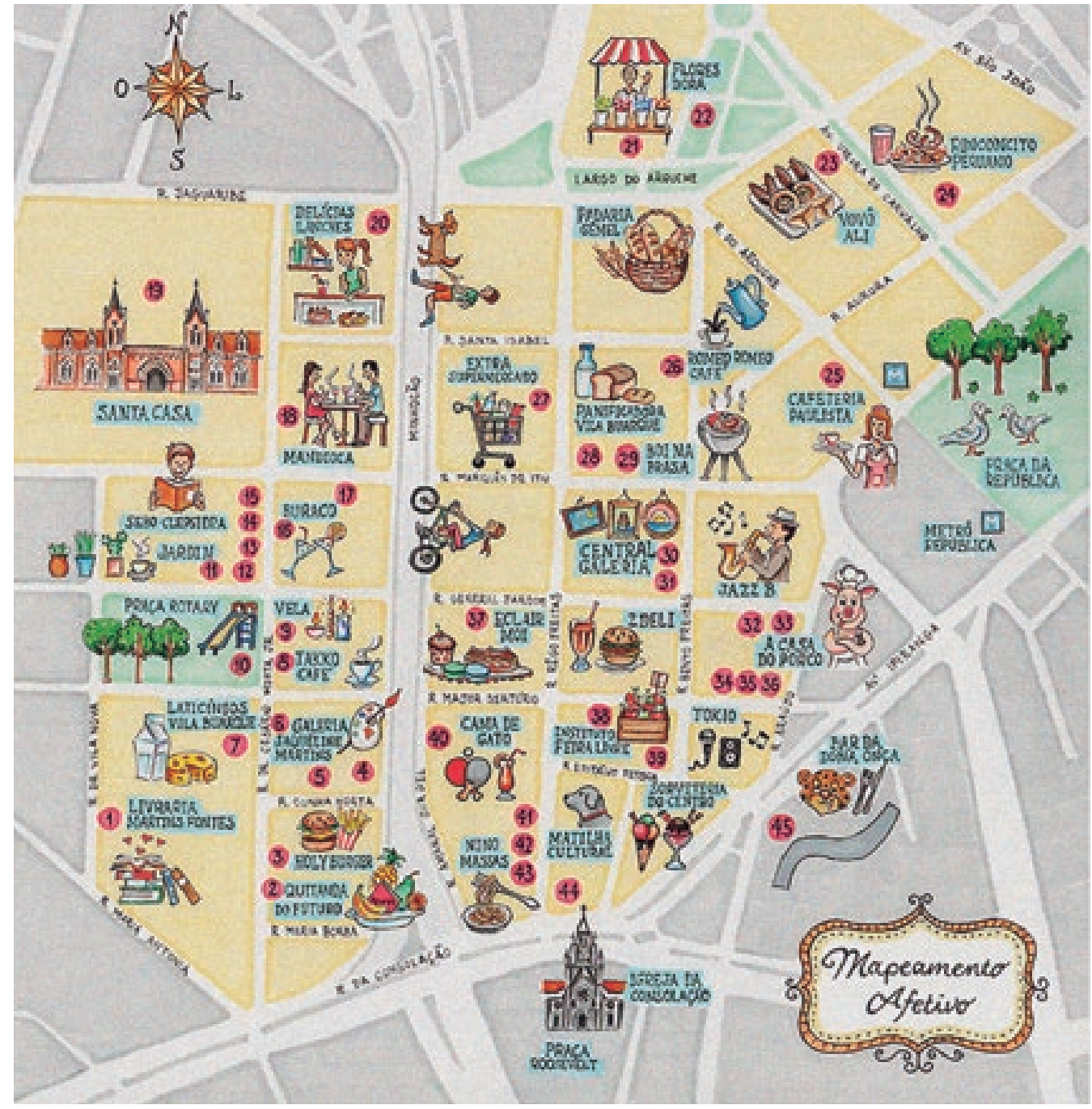

Fig. 3.3.2

llustração

"Mapeamento Afetivo

Região Central de São Paulo". Acupuntura urbana, s/d. que a maioria dos destaques são estabelecimentos comerciais e destes a maioria são voltados para um público com alto poder aquisitivo: não encontramos, por exemplo, o supermercado Futurama, localizado na rua General Jardim, mas encontramos - na mesma rua - o restaurante de uma estrela Michelin "Casa do Porco", reconhecido pelos elevados preços dos seus pratos. Devemos destacar que a incorporadora Magik jC, com a linha Bem Viver Centro, passou a atuar na região central por meio de empreendimentos residenciais voltados para o mercado popular, enquadrado no programa habitacional Minha Casa Minha Vida, incompatíveis com os preços praticados pela maioria dos esta- 
belecimentos destacados no mapa. Verificamos, portanto, que até mesmo nos empreendimentos voltados para habitação social se associa a sua localização a estes estabelecimentos. Colocamos em questão, portanto, a qual público esta transformação do espaço estaria servindo.

Por um lado, Alcântara chama a atenção ao uso recorrente da palavra "gentrificação" entre o público hipster e até mesmo pelos proprietários dos estabelecimentos, demonstrando preocupação com as transformações em curso na região. Por outro, esta simbiose entre estabelecimentos comerciais para as classes média-altas e altas e novos empreendimentos imobilários nos dizem sobre uma disputa por espaço que envolve de um lado a disputa entre diferentes setores, do outro, classes sociais. Estabelecimentos comerciais e empreendimentos imobiliários não necessariamente constituem uma coalizão pactuada pela transformação da região, por vezes os próprios proprietários dos estabelecimentos se mostram preocupados com o desenvolvimento urbano, mas ambos se alimentam da mesma cena. Para elucidar melhor esta transformação em curso iniciamos então uma nova análise quantitativa e transversal das transformações da propriedade por meio de mudanças no uso e ocupação do solo nesta porção do território, entre o final do século XX e os dias de hoje.

Nos valemos aqui das áreas utilizadas para a cobrança do IPTU na cidade de São Paulo, divididas em 16 usos diferentes ${ }^{119}$. O cômputo destas áreas, dividido por quadras e atualizado anualmente ${ }^{120}$, nos dá uma leitura em escala abrangente das transformações em curso a cada quarteirão. Analisaremos primeiramente alguns pontos importantes na escala da cidade para depois nos debruçarmos especificamente sobre as transformações nas quadras que integram a ZEM do Minhocão.

119. São eles: (1) armazéns e depósitos, (2) comércio e serviço horizontal, (3) comércio e serviço vertical, (4) escola, (5) garagens, (6) industrial, (7) residencial horizontal alto padrão, (8) residencial horizontal médio padrão, (9) residencial horizontal baixo padrão, (10) residencial vertical alto padrão, (11) residencial vertical médio padrão, (12) residencial vertical baixo padrão, (13) terrenos vagos, (14) uso coletivo (cinema, teatro, clube, templo, etc.), (15) uso especial (hotel, hospital, cartório, etc.), (16) outros usos (uso e padrão não previsto).

120. A prefeitura disponibiliza online os dados entre os anos de 1995 e 2019. 
Gráf. 3.3.2

Evolução área

construída e

lotes ocupados

Contribuinte Imobiliário

(IPTU).

-.. Lotes ocupados
MSP. Cadastro de

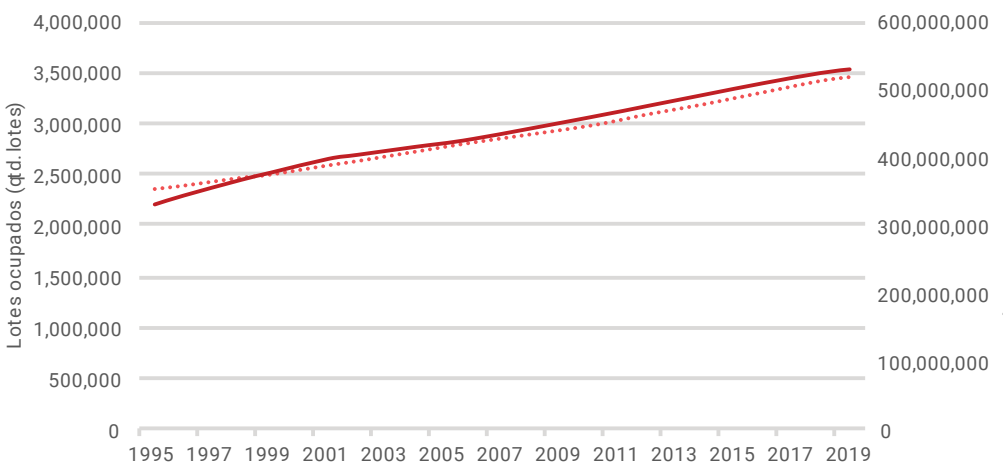

1995199719992001200320052007200920112013201520172019

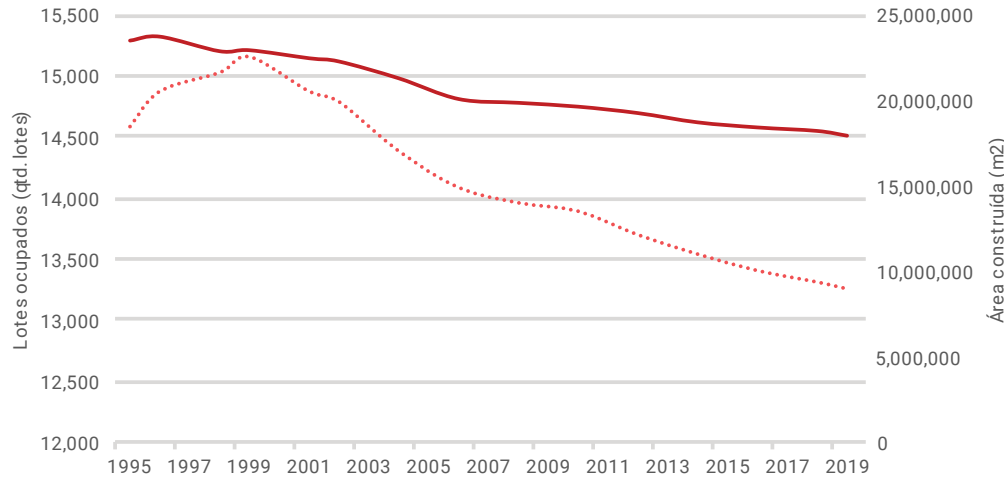

Gráf. 3.3.3

Evolução área construída e lotes ocupados por usos industriais MSP. Cadastro de Contribuinte Imobiliário (IPTU).

- Área construída

... Lotes ocupados

\section{Gráf. 3.3.4}

Evolução lotes ocupados por terrenos vagos MSP. Cadastro de Contribuinte Imobiliário (IPTU).

\section{... Lotes ocupados}

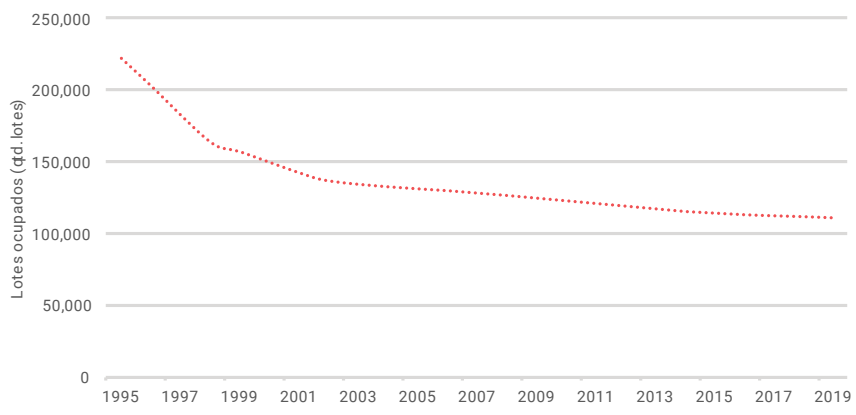



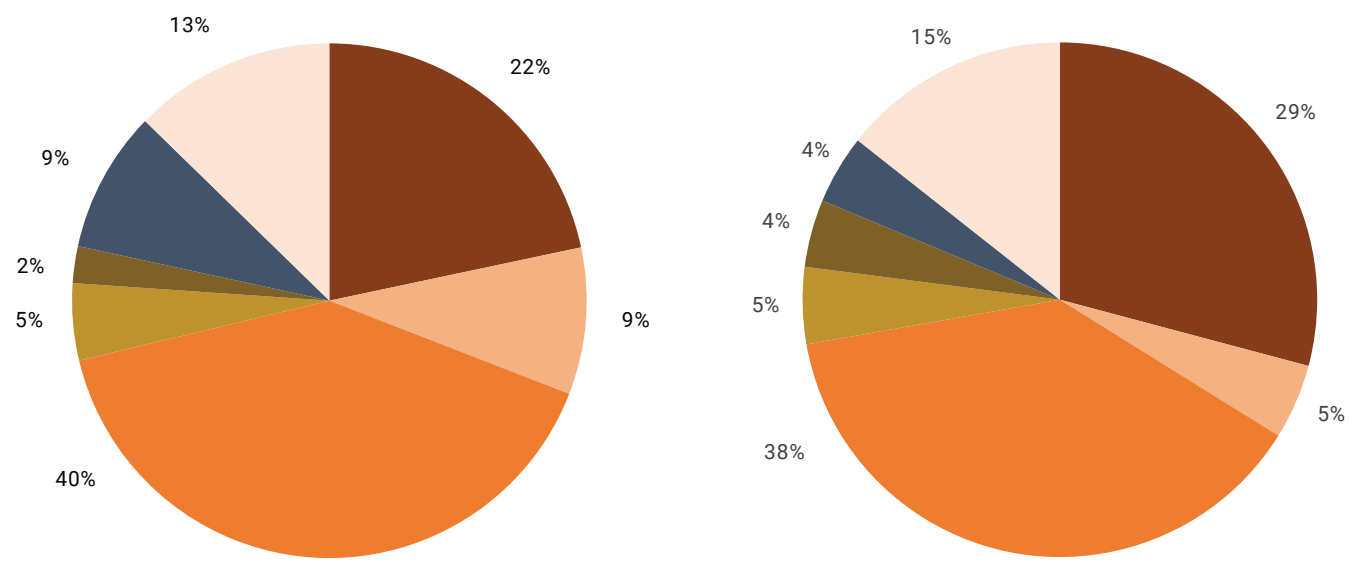

Em primeiro lugar, devemos destacar que ao longo do período estudado há, em termos totais, uma tendência ao aumento do número total de lotes computados na escala da cidade (Gráf. 3.3.2). Podemos supor que à medida que a cidade se desenvolve, lotes maiores são divididos em menores causando um aumento no número total de lotes, que é praticamente constante ao longo de todo o período analisado. Por outro lado, os dois usos que sofrem um movimento contrário a este, de diminuição da quantidade de lotes ocupados por este uso, são o industrial (gráf. 3.3.3) e os terrenos vagos (gráf. 3.3.4). Podemos afirmar, com isso, que a cidade se desenvolve principalmente ocupando terrenos vagos e áreas industriais ${ }^{121}$.

Ao nos debruçarmos especificamente sobre a ZEM do Minhocão, a relação é um pouco diferente, conforme o gráfico que apresenta a porcentagem das áreas de terreno ocupadas por cada uso, o primeiro do ano de 1995 (gráf. 3.3.5), e o segundo de 2019 (gráf. 3.3.6),. O gráfico nos ajuda a quantificar aquilo que observamos de forma fragmentada no nível da rua. Os usos que cresceram em porcentagem de forma significativa sobre o total são: residencial vertical médio padrão (4\%), garagens (2\%), vertical alto padrão (2\%), vertical baixo

121. Curioso observar sobre o uso industrial o aumento no número de lotes ocupados por indústrias até 1999, que poderia ser explicado por uma substituição de indústrias de grande porte por indústrias menores, ocupando com uma mesma área construída um maior número de lotes. 
Gráf. 3.3.7

Evolução áreas construídas e lotes ocupados por uso residencial horizontal baixo padrão ZEM Minhocão. Cadastro de Contribuinte Imobiliário (IPTU).

- Área construída

... Lotes ocupados

\section{Gráf. 3.3.9}

Evolução áreas construídas e lotes ocupados por uso residencial horizontal médio padrão ZEM Minhocão. Cadastro de Contribuinte Imobiliário (IPTU).

\section{Área construída}

... Lotes ocupados
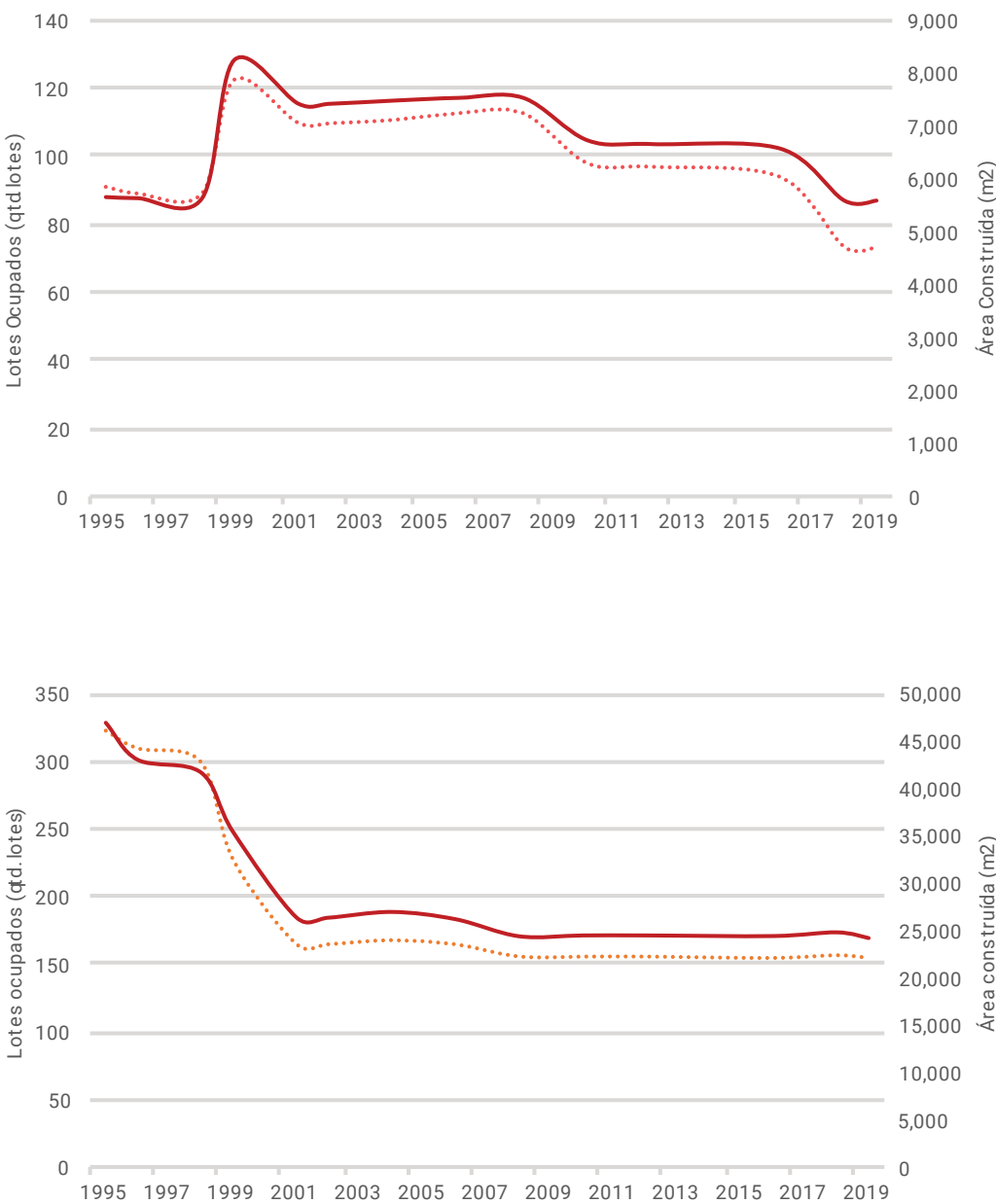

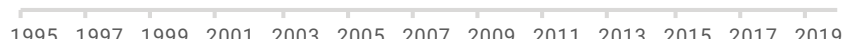

Gráf. 3.3.11

Evolução áreas construídas e lotes ocupados por uso residencial horizontal alto padrão ZEM Minhocão. Cadastro de Contribuinte Imobiliário (IPTU).

\footnotetext{
- Área construída ... Lotes ocupados
}

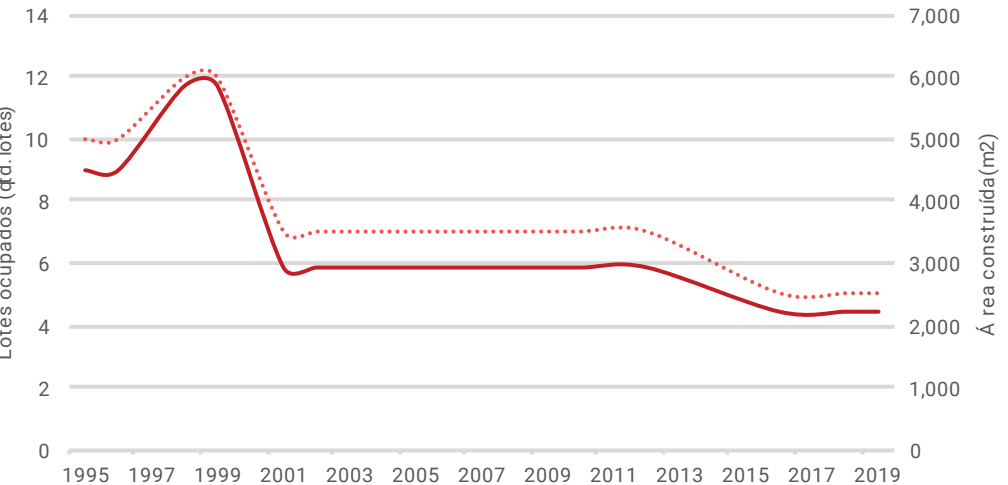

$\begin{array}{lllllllllllll}1995 & 1997 & 1999 & 2001 & 2003 & 2005 & 2007 & 2009 & 2011 & 2013 & 2015 & 2017 & 2019\end{array}$ 

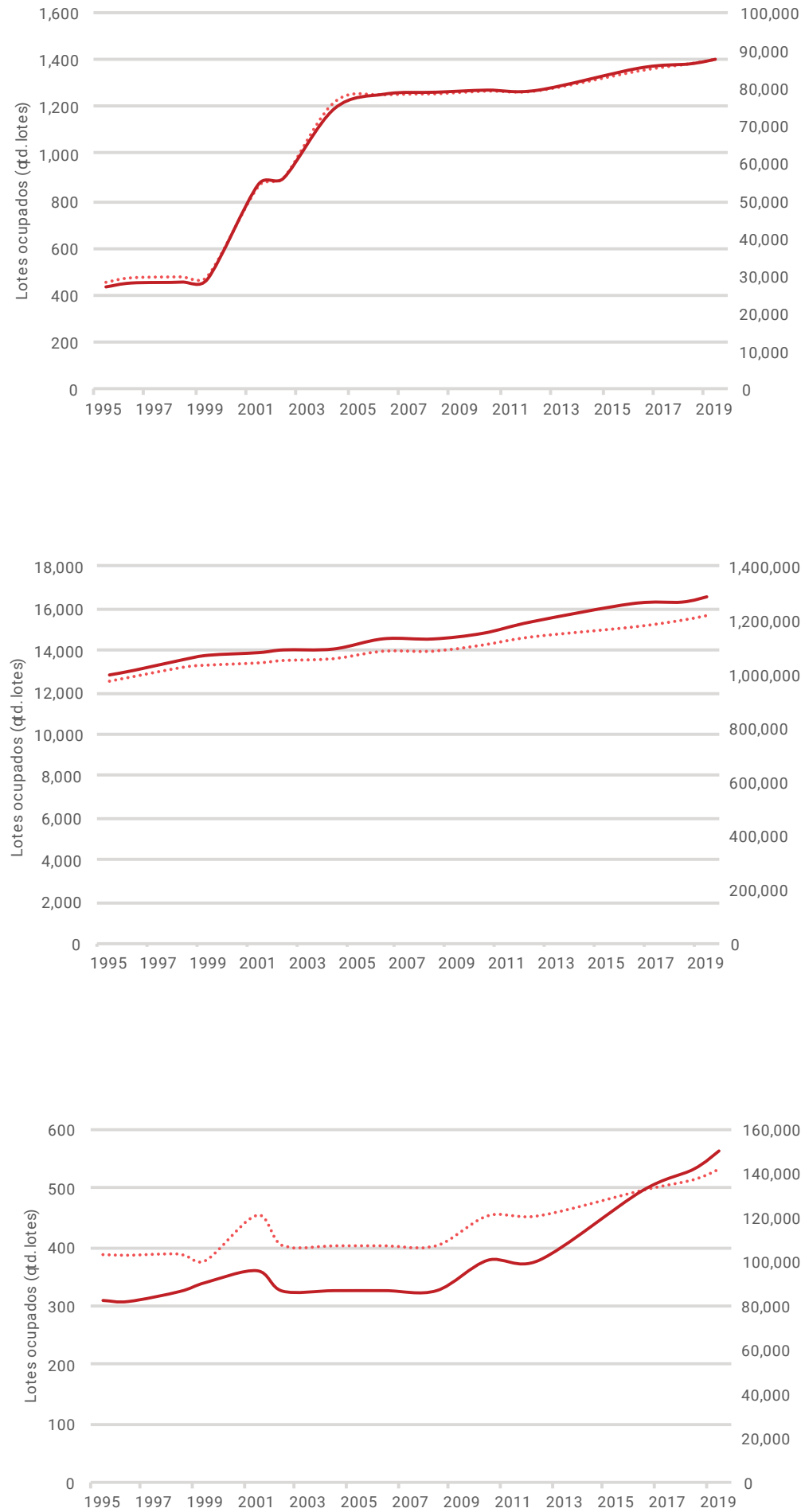

\section{Gráf. 3.3.8}

Evolução áreas construídas e lotes ocupados por uso residencial vertical baixo padrão ZEM Minhocão. Cadastro de Contribuinte Imobiliário (IPTU).

\section{- Área construída \\ ... Lotes ocupados}

Gráf. 3.3.10

Evolução áreas construídas e lotes ocupados por uso residencial vertical médio padrão ZEM Minhocão. Cadastro de Contribuinte Imobiliário (IPTU).

- Área construída

... Lotes ocupados
Gráf. 3.3.12

Evolução áreas construídas e lotes ocupados por uso residencial vertical alto padrão ZEM Minhocão. Cadastro de Contribuinte Imobiliário (IPTU).

\section{- Área construída} ... Lotes ocupados 
Gráf. 3.3.13

Evolução lotes ocupados por terrenos vagos ZEM Minhocão. Cadastro de Contribuinte Imobiliário (IPTU).

.. Lotes ocupados
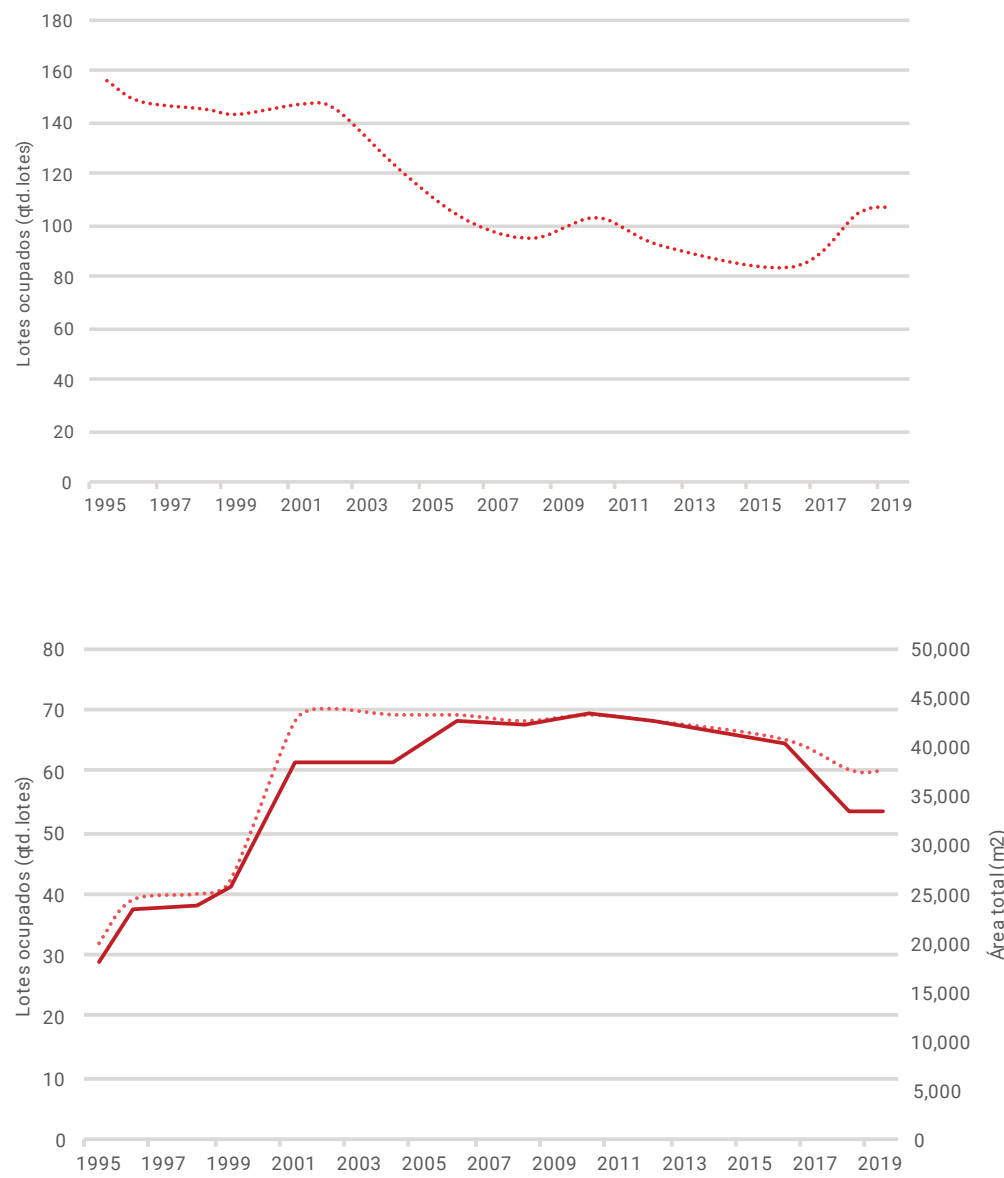

padrão (1\%) e usos especiais(1\%). Já as áreas que diminuíram em porcentagem são: terrenos vagos (-4\%), residencial horizontal médio padrão (-4\%), comércio e serviço horizontal (-2\%), industrial (-1\%), residencial horizontal alto padrão (-1\%). Verificamos, com isso, que de forma geral se trata da substituição de terrenos vagos e construções horizontais por edifícios residenciais de médio, alto e baixo padrão ou por espaços para garagem. Estes últimos atrelados justamente ao aumento de número de edifícios residenciais com vagas de garagem e ao aumento da demanda por espaço de estacionamento.

Nos debruçamos especificamente sobre a elevação da área de edifícios residenciais verticais de todos os padrões $(+7 \%)$ sobre os horizontais (-5\%) (gráf. 3.3.7 a 3.3.12). Verificamos que o aumento dos edifícios verticais de baixo padrão se dá principal- 
mente a partir do ano 2000 e dos edifícios verticais de médio padrão de forma praticamente constante ao longo de todo o período estudado. Por outro lado o aumento da área dos edifícios residenciais de alto padrão pode ser verificado de forma mais intensa a partir de 2012. Como vimos no gráfico anterior, os edifícios verticais de alto padrão passam de representar $1 \%$ do total construído para $3 \%$, portanto verificamos um aumento de $300 \%$. Por outro lado, verificamos que a partir de 2012 há uma clara diminuição, especificamente dos imóveis residenciais horizontais de alto padrão e dos de baixo padrão, este último com diminuição mais expressiva a partir de 2016.

Especificamente nas áreas destinadas a garagens e terrenos vagos valem aqui alguns comentários. De forma coerente com o resto da cidade, verificamos uma diminuição praticamente constante do número de terrenos vagos na ZEM do Minhocão (gráf. 3.3.13), porém a partir de 2016 há uma mudança nesta trajetória, a qual se inverte. Acreditamos que essa mudança possa se dever à demolição de edificações de outros usos (horizontais), criando espaços vazios à espera de um novo uso (vertical). Não podemos afirmar com segurança, com esses dados, que se tratem de processos especulativos de retenção de terras, podendo também se tratar de áreas em processo de incorporação, mas podemos afirmar com segurança que o aumento sinaliza uma transformação na paisagem do lugar.

Finalmente verificamos que o aumento das áreas de garagens é um processo anterior (gráf. 3.3.14), ao qual nos debruçamos neste trabalho, que aconteceu ainda na década de 1990. Recentemente verificamos, pelo contrário, uma diminuição das áreas de garagens, que podemos explicar pela combinação de dois fatores: terrenos antigamente destinados a estacionamentos passando por um processo de transformação e, fruto da nova regulamentação urbanística, a construção de edifícios residenciais sem vagas de garagens.

Em suma, nesta leitura das áreas consumidas por cada uso, verificamos uma mudança do perfil da construção que vai de acordo com a intensificação da produção que vimos no capítulo 
anterior. Poderíamos dizer que a mudança é tímida (7\%), porém em se tratando de uma área consolidada o número nos parece expressivo. Cabe reforçar o expressivo aumento do número de edifícios alto padrão (300\%).

Para mapear a valorização imobiliária, sobretudo nesta região, nos valemos de algumas matérias de jornal que nos ajudam a iluminar este processo ${ }^{122}$. Em uma matéria da Folha de S. Paulo de 2016 sobre o Centro da cidade, anuncia-se logo no título que a "reocupação da região por jovens gera onda de aumento de preços" ${ }^{\prime 23}$. Nela declara-se:

O centro de São Paulo pulsa, apesar da desaceleração vivida pelo mercado imobiliário. Do primeiro trimestre do ano passado para o mesmo período de 2016, o preço médio do aluguel por metro quadrado na cidade caiu 1,9\%, segundo o portal VivaReal. Enquanto isso, os aluguéis na região subiram $10 \%$. ${ }^{124}$

Em 2017, outra matéria anunciava "atrações gastronômicas revitalizam região do centro entre praça da República e Amaral Gurgel". Outra de 2018, intitulada "Apês compactos no centro de São Paulo estão no radar de jovens, recém-casados e apps de aluguel" nota que o centro "é o grande protagonista" da retomada da venda de imóveis na capital paulista traduzindo-se em um aumento de mais de $107 \%{ }^{125}$. Ainda em 2018 , em outra notícia, intitulada "Boom de bares, restaurantes e apês redesenha região do centro conhecida como Nova República”, Fábio Redondo, diretor da rede Buenas Hotéis, declara: "a ideia é atrair visitantes e

122. Nos valemos aqui de notícias de jornal tendo em vista que não tivemos acesso a bancos de dados sobre valor de locação e compra de imóveis que nos permitissem mensurar tal valorização.

123. Yuri, Débora. Reocupação da região por jovens gera onda de aumento de preços. Folha de S. Paulo, 01 de maio de 2016 (link para site na bibliografia).

124. Idem

125. Moura, Eduardo. Apês compactos no centro de São Paulo estão no radar de jovens, recém-casados e apps de aluguel. Folha de S. Paulo, 31 de agosto de 2018 (link para site na bibliografia). 
moradores de São Paulo que não frequentam essa área” ${ }^{126}$. Nesse mesmo sentido, o diretor da Setin em 2015 anunciava também em matéria de jornal que "a chegada de novos empreendimentos tende a criar um círculo virtuoso, que vai melhorar a oferta de serviços e a própria segurança"127.

A história montada com base nas matérias de jornal não pode ser destituídas de uma intenção que narra com clima de otimismo as transformações da região central, conjugando recorrentemente atividade imobiliária a novos estabelecimentos comerciais. O resultado desta relação que traçamos como simbiótica é esse "círculo virtuoso" que o diretor da Setin anuncia. Neste sentido, lembramos o que Brandão fala sobre a potência dos "localismos":

\begin{abstract}
As listas intermináveis de vantagens relativas locais contrapõem um mundo clean, pouco conflituoso, diversificado, de indivíduos talentosos, convivendo proximamente etc., e um mundo dark, pouco solidário, massificado, rígido, politizado de classes sociais antagônicas, etc. (Brandão, 2012, p.43).
\end{abstract}

Tratando especificamente do Minhocão, em 2017, foi publicada uma matéria cuja chamada era: "Novos empreendimentos fazem as pazes com o Minhocão" 128 e nela destaca-se o empreendimento Bem Viver consolação como um dos principais personagens desta "trégua". Em outra matéria, agora de 2019, intitulada "Ainda no papel, renovação do Minhocão já atrai empreendimentos", a jornalista escreve: "quem transita pelos 2,7 km do Elevado Presidente João Goulart, mais conhecido como Minhocão, já nota uma diferença nas placas de vende-se ou aluga-se: afixadas em janelas, elas já mencionam o Parque Minhocão como chamariz" ${ }^{129}$ (fig. 3.3.3). Finalmente, uma matéria de 2019 aponta um

126. Sanchez, Leonardo. Boom de bares, restaurantes e apês redesenha região do centro conhecida como Nova República. Folha de S. Paulo, 31 de agosto de 2018 (link para site na bibliografia).

127. Pfeifer, Ismael. 'Cicatriz', Minhocão inibe empreendimentos ao seu redor. Folha de S. Paulo, 20 de outubro de 2015 (link para site na bibliografia).

128. Rodrigues, Renata H. Novos empreendimentos fazem as pazes com o Minhocão. Folha de S. Paulo, 24 de setembro de 2017 (link para site na bibliografia). dimentos. Folha de S. Paulo, 02 de junho de 2019 (link para site na bibliografia). 


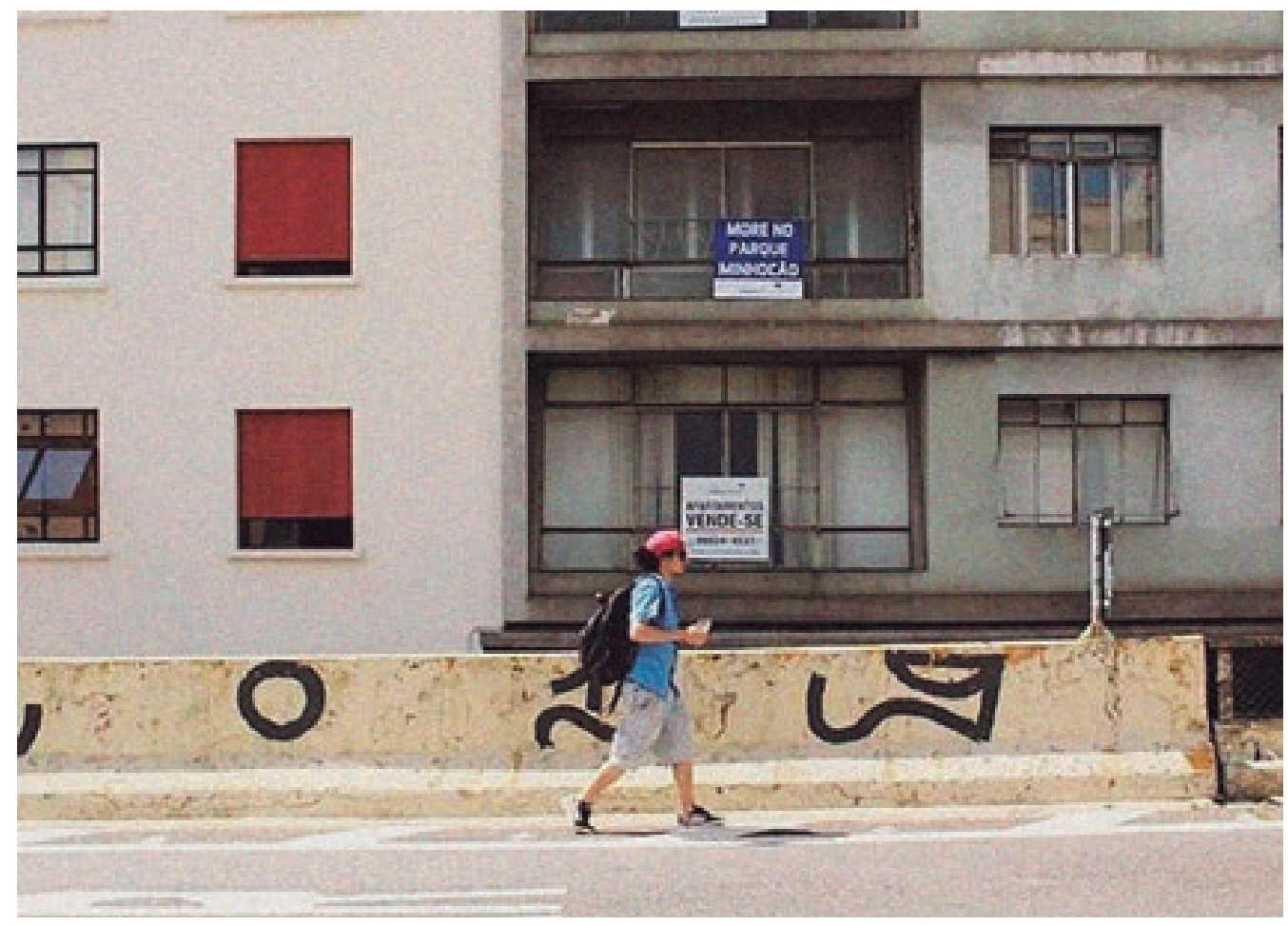

Fig. 3.3.3

Apartamentos à venda de frente para o Elevado. Foto: Gyovana Freire, 2019. período recente de valorização imobiliária no Centro da cidade: constatou uma elevação do preço por metro quadrado de, em média, 52\% a partir de $2010^{130}$ consequência de uma "onda de novos negócios hipster”. As sinergias urbanas, portanto, parecem ganhar sentido de um único movimento de valorização que se realiza no espaço e por meio de agentes que estão pulverizados, e os relatos jornalísticos parecem projetar estes desejos, talvez frutos do consenso que mira na transformação da região. Movimento por um lado motivado pelo mercado imobiliário, por outro por novos estabelecimentos comerciais e de serviços para um novo público, que resulta segundo matéria acima citada no aumento expressivo de 52\% dos valores dos imóveis a partir de 2010. A continuação discutiremos as implicâncias deste processo em termos sócio-espaciais.

130.Lacerda, Fernanda. Novos negócios hipster valorizam imóveis do centro de São Paulo. Folha de S. Paulo, 27 de novembro de 2019 (link para site na bibliografia). 


\section{Limites invisíveis: 0 apagamento do popular}

No sentido de salientar as qualidades populares desta região e reforçar a leitura de que este espaço se trata de um local em disputa pelas camadas ditas "populares", abaixo traçamos um perfil avesso às transformações que discutimos anteriormente. Buscamos iluminar um certo perfil popular desta região, que parece ser apagado tanto pelas notícias de jornal, que celebram a valorização da área, quanto pelo próprio relatório da prefeitura veiculado para os estudos do PIU Parque Minhocão. Cabe aqui discutir como essa porção do espaço se diferencia do resto e qual é a população em situação de maior vulnerabilidade: aquela que sofre mais rapidamente com os processos de renovação urbana.

Conforme vimos, o processo de intensificação da produção imobiliária alavanca processos de valorização da terra, desencadeando a expulsão das populações que não conseguem arcar com a elevação dos preços, tanto da moradia quanto dos outros custos fundamentais para a sua reprodução. Por se tratar de um processo não imediato, mas que leva anos, envolvendo contratos de longa duração entre proprietários e locadores, estas pessoas se tornam agentes da resistência a este processo na disputa pelos rumos da produção do espaço.

O primeiro mapa (mapa 3.3.2) ilustra por meio de dados oficiais do Censo de 2010 o rendimento nominal mensal médio dos domicílios de cada setor censitário. Mapa similar ao exposto pelo grupo de trabalho intersecretarial Parque Minhocão que vimos no capítulo 2 , mas neste caso a segregação das faixas de renda obedece os critérios utilizados na concessão de benefícios à produção imobiliária e ao acesso a programas habitacionais: (1) de um a três salários-mínimos - HIS 1, (2) de três a seis salários-mínimos - HIS 2, (3) de seis a 10 salários-mínimos HMP, (4) e (5) produção sem benefícios (acima de 10 salários mínimos). Na região do entorno do Minhocão, verificamos a presença de rendimentos médios que vão de três a 20 salários-mínimos, com predominância das médias que variam entre $6 \mathrm{e}$ 10 salários-mínimos. Lembrando que o Plano Diretor incentiva a produção de empreendimentos habitacionais para famílias de um a 10 salários-mínimos (HIS 1, HIS 2 e HMP), com benefí- 
Mapa 3.3.1

Rendimento nominal mensal médio por domicílio permanente (em salários-mínimos), IBGE, Censo 2010.

-- ZEM Minhocão $<1$ s.m.

$1-3$ s.m.

3-6 s.m

6-10 s.m.

10-20 s.m.

$>20$ s.m

(1)

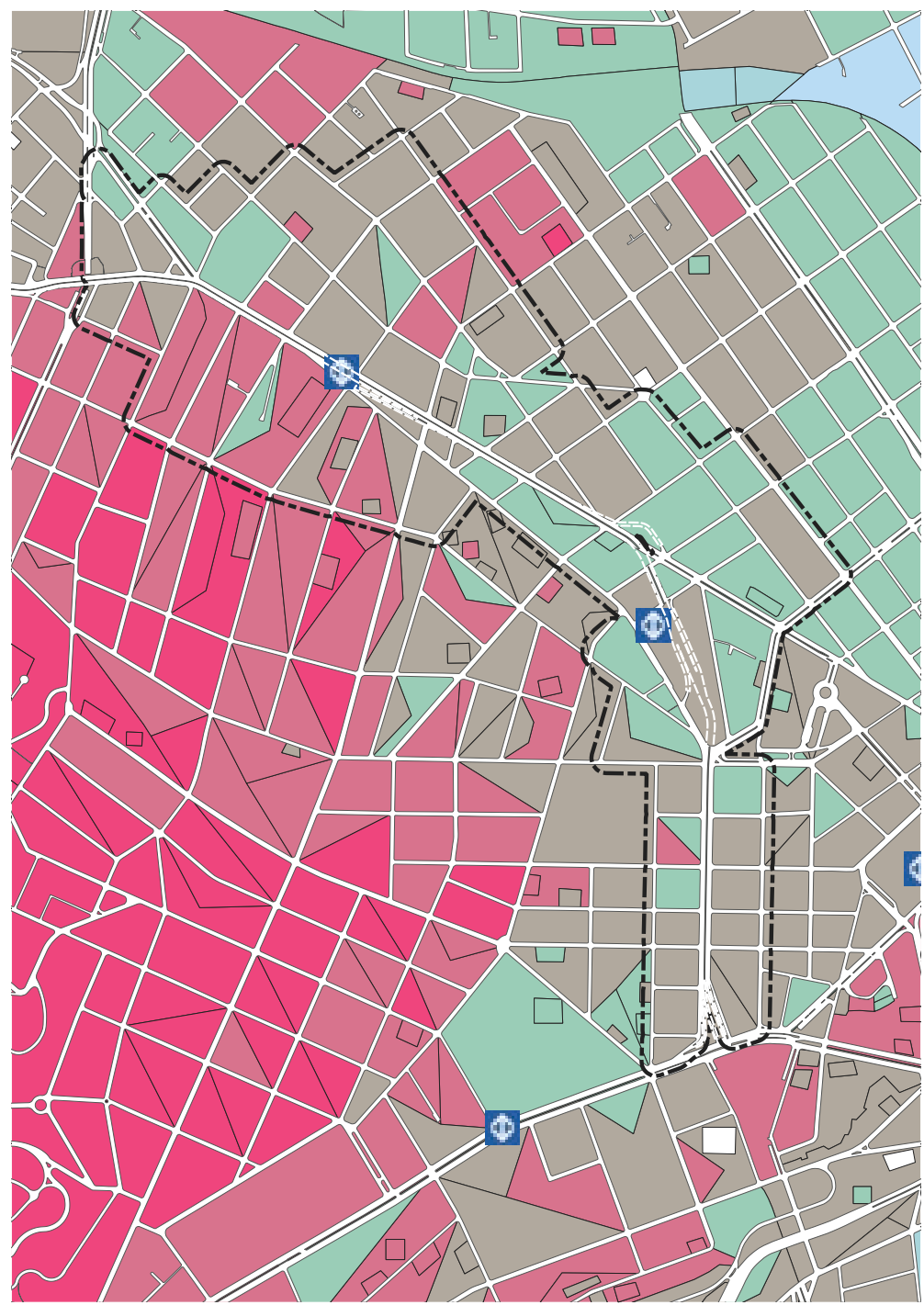

cios ainda maiores para os empreendimentos para famílias de um a 6 salários-mínimos (HIS 1 e HIS 2).

Na sequênca, ilustramos (mapa 3.3.3) a renda média agora dos responsáveis por domicílio particular permanente, organizado em salários-mínimos da época (2010). A situação ilustra agora uma região dominada por representantes de domicílio que recebem entre três e seis salários-mínimos, misturados a alguns setores com responsáveis com rendas médias mais baixas (de um a três salários-mínimos) e outros com rendas mais altas (de 6 a 10 s.m.). 


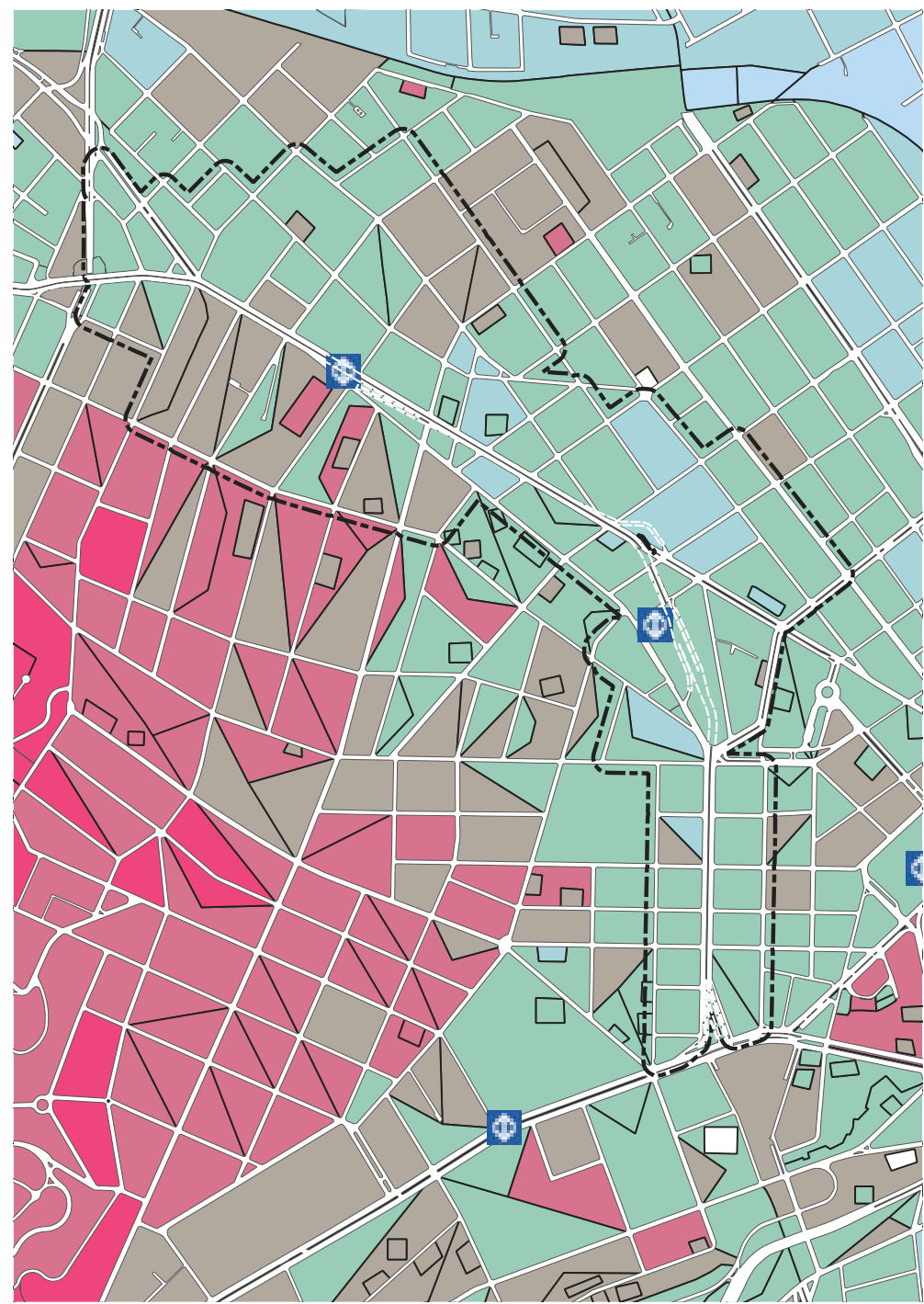

Ambos mapas, evidenciam uma região de fronteira entre populações com altos ingressos, habitantes dos bairros de Higienópolis e Pacaembu, e populações com menores ingressos do outro lado do Elevado, nos bairros de Campos Elíseos e República. Por vezes, o Minhocão parece marcar um limite claro entre diferentes perfis socioeconômicos, como na porção mais a noroeste do Elevado, entre a Santa Cecília e a Barra Funda/Campos Elíseos e por vezes uma fronteira mais diluída como na porção leste, mais próxima do Centro, entre a Vila Buarque e a República.
Mapa 3.3.2

Rendimento nominal mensal médio do responsável pelo domicílio (em saláriosmínimos),IBGE, Censo 2010.

- ZEM Minhocão $<1$ s.m.

1-3 s.m.

3-6 s.m

6-10 s.m.

10-20 s.m.

$>20$ s.m

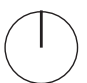


Mapa 3.3.3

Porcentagem de pessoas residentes de cor preta e parda por setor censitário. IBGE, Censo 2010.

-- ZEM Minhocão $<10 \%$

$10 \%-20 \%$

$20 \%-30 \%$

$30 \%-40 \%$

$>40 \%$

(1)

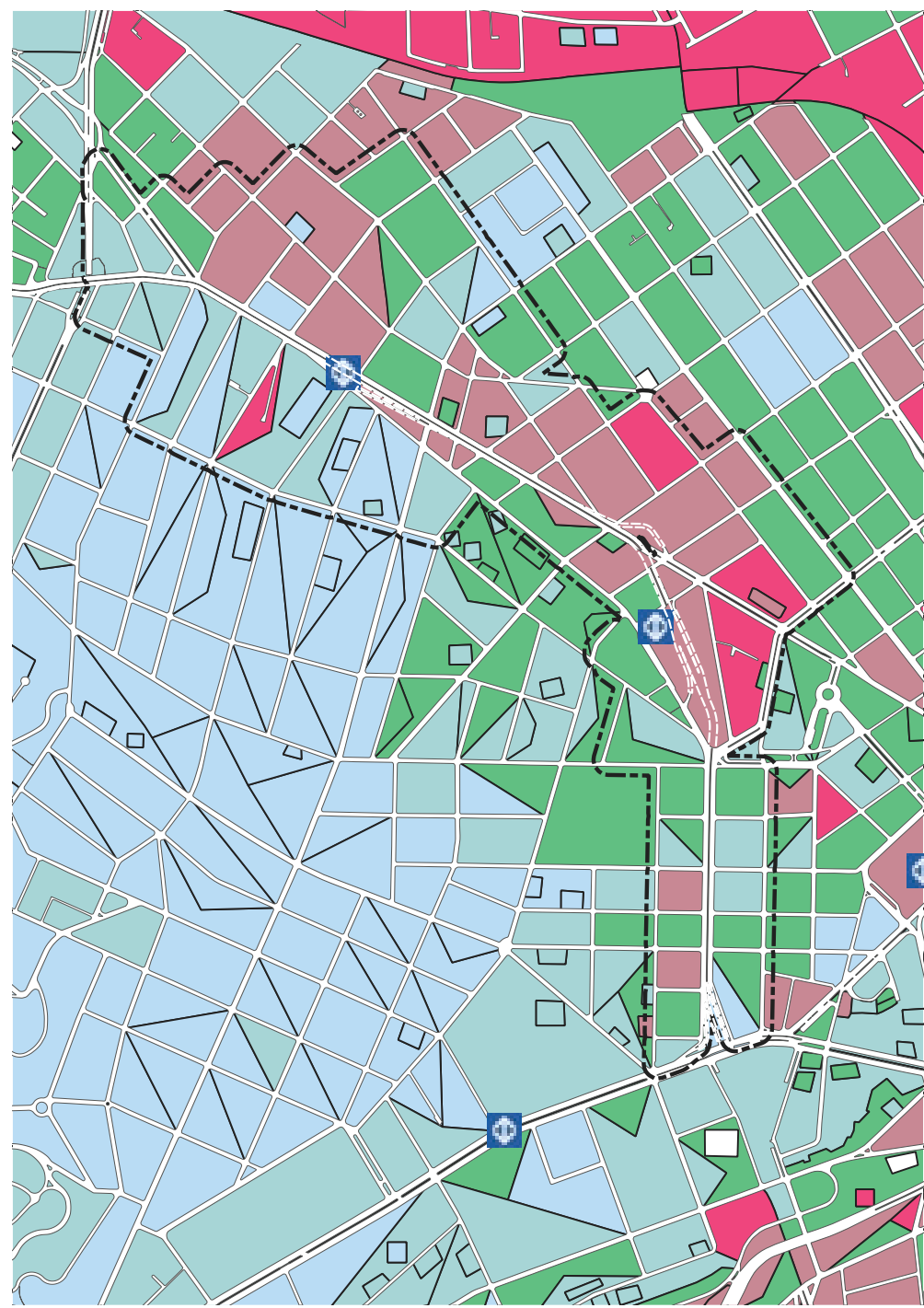

No seguinte mapa (mapa 3.3.4), ilustramos a porcentagem de pessoas que se declararam de cor preta e parda sobre o total da população. Em azul, marcamos aqueles setores censitários no qual a população preta e parda representa menos de $10 \%$ da população residente, localizados, principalmente, nos bairros de Higienópolis e Santa Cecília. Em rosa saturado iluminamos os setores nos quais esta população representa mais de $40 \%$ do total de residentes, presentes em alguns setores da região central, principalmente no bairro de Campos Elíseos. Verificamos que as cores mais próximas ao vermelho, que representam regiões com 
mais de 30\% de residentes da cor preta e parda se concentram: junto à orla ferroviária na região mais próxima da estação Luz, junto ao Elevado, na Av. São João e na região mais próxima da colina histórica. Devemos lembrar ainda que no município de São Paulo pretos e pardos representam 37\% do total da população, de acordo com o Censo 2010, portanto são regiões que se aproximam mais de uma certa média municipal em termos de cor e raça. Podemos dizer, então, que na região do entorno imediato do Minhocão encontramos uma população que, em termos de cor/raça, se aproxima à média do município, com forte presença da população que varia entre 20 e $40 \%$ de pretos e pardos sobre o total.

Estes mapas nos mostram uma correlação evidente entre renda e cor declarada: retrata uma população com renda alta, majoritariamente branca, a sudoeste do Elevado (Bairros Higienópolis e Pacaembu) e uma população mais próxima à média do município no sentido norte e leste, com renda do responsável pelo domicílio abaixo dos 10 salários-mínimos e presença importante de pessoas da cor preta e parda (Bairros Barra Funda, Campos Elíseos e República). O Elevado aqui aparece como uma zona de transição e, portanto, de conflitos de classe; um espaço onde as desigualdades socioterritoriais emergem.

A continuação, ilustramos a concentração de cortiços e a presença de população em situação de rua na região ${ }^{131}$. O mapa (mapa 3.3.5) ilustra a população em situação de maior vulnerabilidade habitacional pela presença de moradias precárias, acessíveis para a população de menores ingressos e daqueles em situação de rua, que se utilizam do Elevado como abrigo. Nele verificamos que existe um alto número de pessoas em situação de rua que se concentra (e se desloca) em lugares próximos ao Elevado: em 2009, foram registradas 132 pessoas em situação de rua no entorno do Minhocão e 141 pessoas em 2015, o que revela certa estabilidade em números. Por outro lado, verificamos a presença de cortiços, tipologias de moradia precária que certamente variam muito e

131. Dados dos cortiços obtidos pelo portal Habitasampa da SEHAB que datam de 2006 e da população em situação de rua do censo específico desta população realizados em 2009 e 2015. 


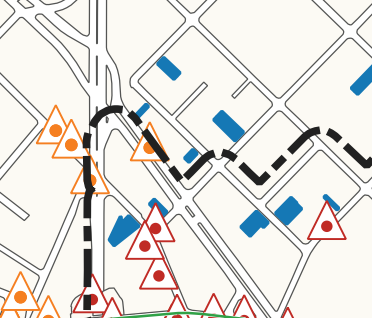

2.0.2. 
conformam uma "região encortiçada"132 que, embora possa perder ou ganhar novos imóveis, tem se perpetuado ao longo das últimas décadas na região. Estes dois levantamentos retratam uma realidade oculta nos dados, mapas e índices apresentados até então nos relatórios da prefeitura sobre a região.

No intuito de nos aproximarmos aos dias atuais, no mapa seguinte (mapa 3.3.6), destacamos as abordagens realizadas pela Operação Baixas Temperaturas em 2017. Nela foram registradas 3.474 abordagens no entorno do Elevado, das quais aproximadamente $60 \%$ das que declararam a cor se tratavam de pessoas da cor preta ou parda. Este dado vem reforçar aquilo que foi registrado no censo população de rua (mapa 3.3.5). Quem frequenta o entorno do Elevado não precisa destes mapas para verificar a forte presença dessa população que apoia-se também em uma rede socioassistencial e de apoio presente na região, como Centros Temporários de Atendimento (CTAs), Centro de Acolhida para População de Rua, diversos equipamentos de saúde, além de equipamentos que servem refeições ao preço de $\mathrm{R} \$ 1,00$. Região também caracterizada pela presença de catadores de materiais recicláveis, trabalhadores eventuais, que orbitam a região face à oferta de oportunidades esporádicas de trabalho e remuneração, ainda que intermitente.

Este detalhamento problematiza o diagnóstico realizado pela Prefeitura sobre o perfil socioeconômico da população que mora no entorno do Minhocão, embasado apenas no índice de vulnerabilidade social (Índice Paulista de Vulnerabilidade Social - SEADE IPVS). Apesar deste índice indicar que a região é de baixa vulnerabilidade, conforme aponta o relatório encaminha-

132. Cabe aqui destacar que o levantamento dos cortiços se trata de um levantamento antigo, de 2006, realizado em apenas alguns bairros da região central. A realização de um censo de cortiços para toda a região central se torna uma pauta importante para iluminarmos a existência deste perfil popular e a real situação de moradia dessa população. A realização do mesmo, pautada na Comissão Executiva Centro a partir de 2016, chegou a carimbar recursos desta operação em 2018. Consequentemente, no começo de 2019 foi realizada a licitação que teve como ganhador o consórcio entre o Instituto Polis e a Peabiru Assessoria Técnica, porém a licitação foi cancelada no mesmo ano por problemas no edital. No ano de 2020, a realização do censo foi novamente inserida dentro da minuta de lei do PIU Setor Central, que deverá incorporar esta demanda.

\section{Mapa 3.3.4}

Localização de cortiços (2006) e da população em situação de rua (2009/2015). SEHAB, Habitasampa 2006; FIPE I CGEO.

\section{- Minhocão \\ -- ZEM Minhocão \\ Cortiços Pop. em situação de rua (2009) Pop. em situação de rua (2015) \\ - Estação de Metrô}

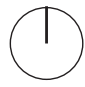




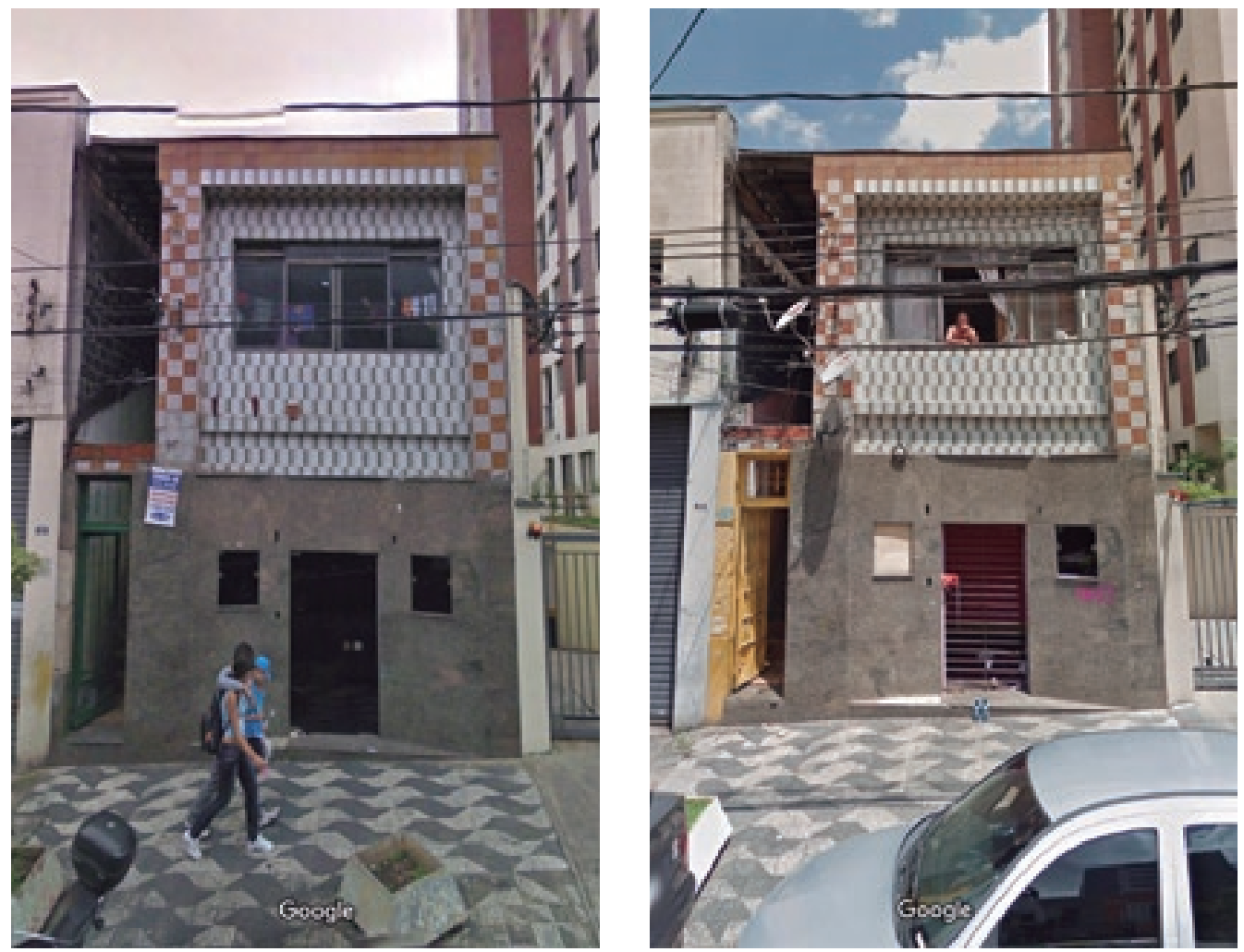

do junto à consulta pública do PIU Parque Minhocão, este mapa retrata uma realidade diferente, indicando forte presença de pessoas em situação de extrema vulnerabilidade.

Em levantamento preliminar por meio de imagens capturadas pela plataforma Google Street View, verificamos a condição recente dos cortiços levantados pela SEHAB naquela data. Nas fotos tiradas por esta plataforma, entre 2017 e 2018, dos 68 cortiços cadastrados na região em 2006, 6 não registram mais habitações em condições precárias evidentes, 5 foram demolidos e encontraram-se vazios, 8 registram placas de "aluga-se quarto" (o que é usado como indicativo de existência de cortiço) e os outros 49 apresentam sinais de que ainda se tratam de moradias precárias, dado o seu estado de conservação, sem nenhuma

\section{Fig. 3.3.4}

Fotografia Al. Ribeiro da Silva, 797 (2010). Google Street View, 2010.

Fig. 3.3.5

Fotografia Al. Ribeiro da Silva, 797 (2010). Google Street View, 2010.

\section{Mapa 3.3.5}

Localização de cortiços (2006) e Abordagens Operação Baixas Temperaturas (2017) SEHAB, Habitasampa 2006; SMDAS I CGEO.

- Minhocão

-- ZEM Minhocão

Cortiços

- Abordagem

- Estação de Metrô 
Fig. 3.3.6

Fotografia Alameda Glete, 1058 (2010) Google Street View, 2010.

\section{Fig. 3.3.8}

Fotografia Avenida Angélica, 41 (2010). Google Street View, 2010.

Fig. 3.3.10

Fotografia Rua

Albuquerque Lins, 350

(2010. Google Street

View, 2010.
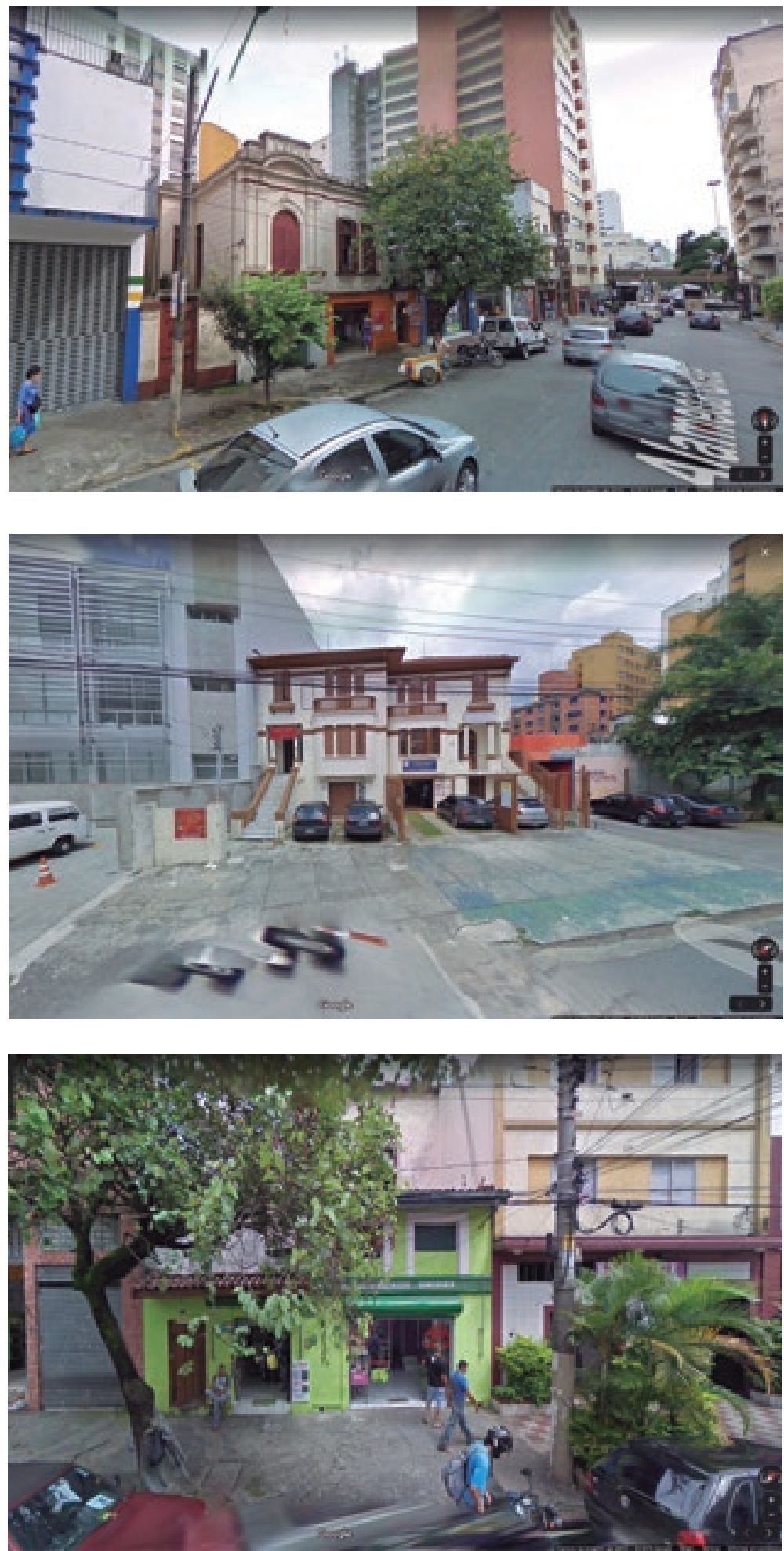


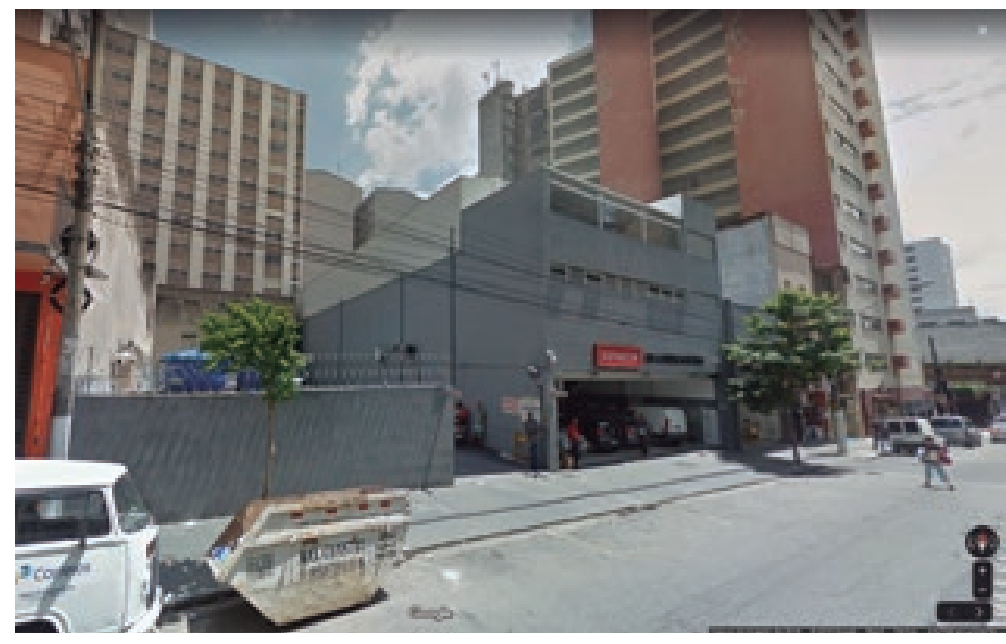

Fig. 3.3.7

Fotografia Alameda Glete, 1058 (2018) Google Street View, 2018.

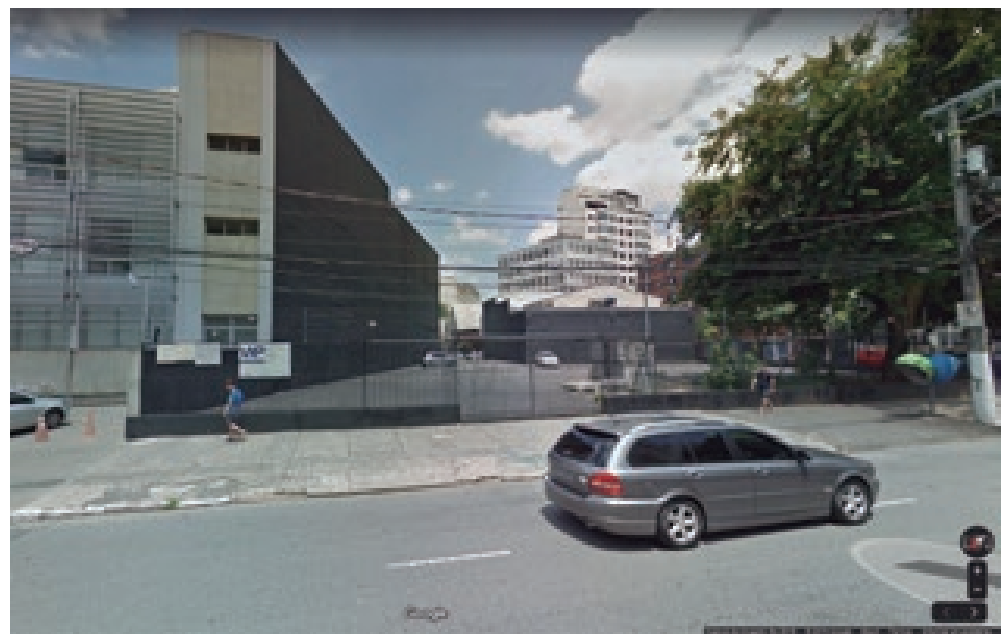

Fig. 3.3.9

Fotografia Avenida Angélica, 41 (2018). Google Street View, 2018.

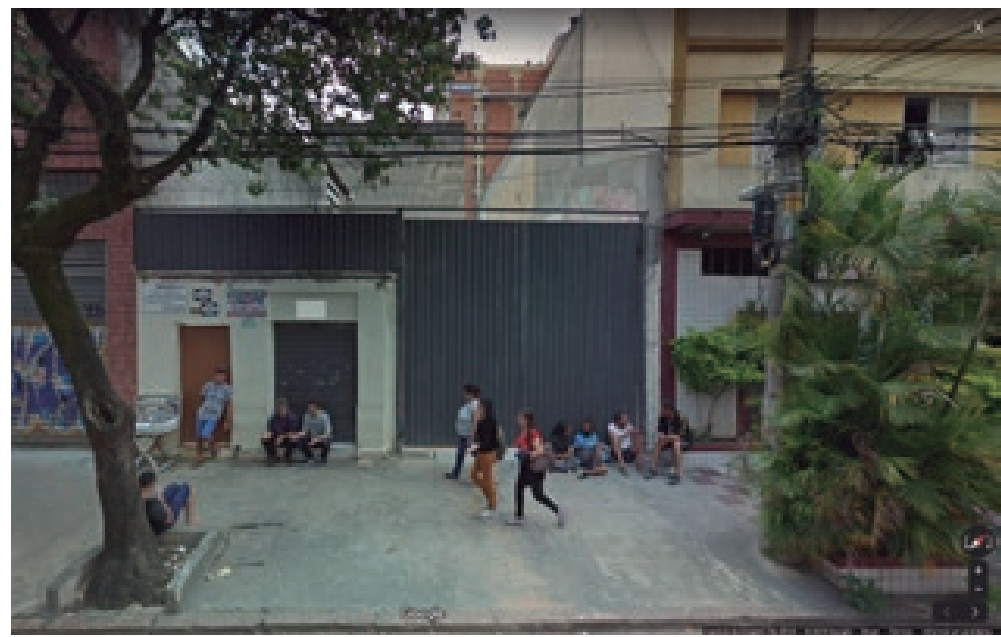

Fig. 3.3.11

Fotografia Rua

Albuquerque Lins, 350 (2018) Google Street View, 2010. 
Fig. 3.3.12

Fotografia Rua Barão de Campinas, 573 (2010) Google Street View, 2010.

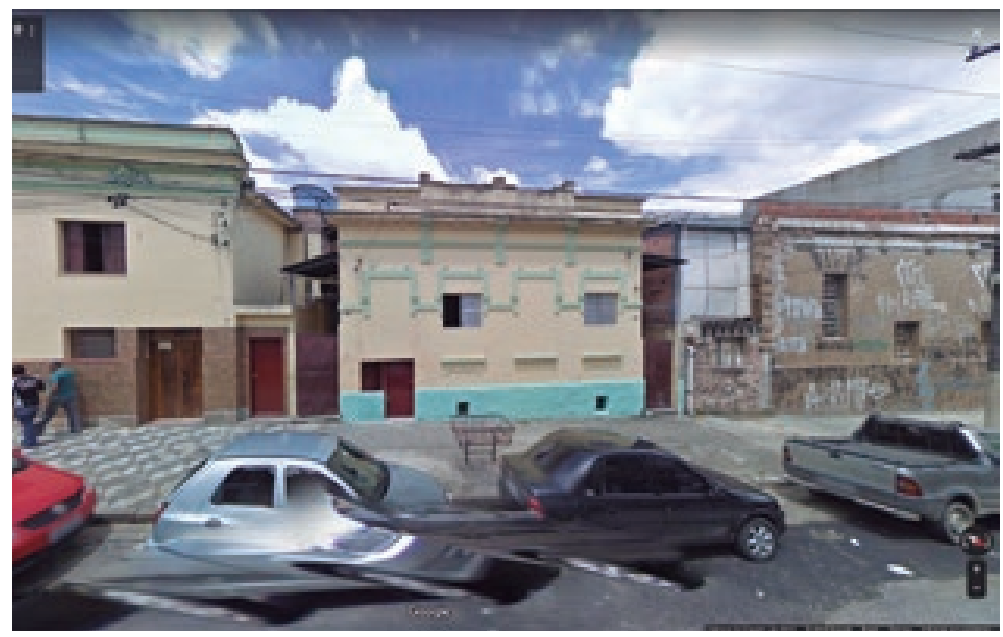

Fig. 3.3.14

Fotografia Rua Barão de Tatuí, 234 (2010) Google Street View, 2010.

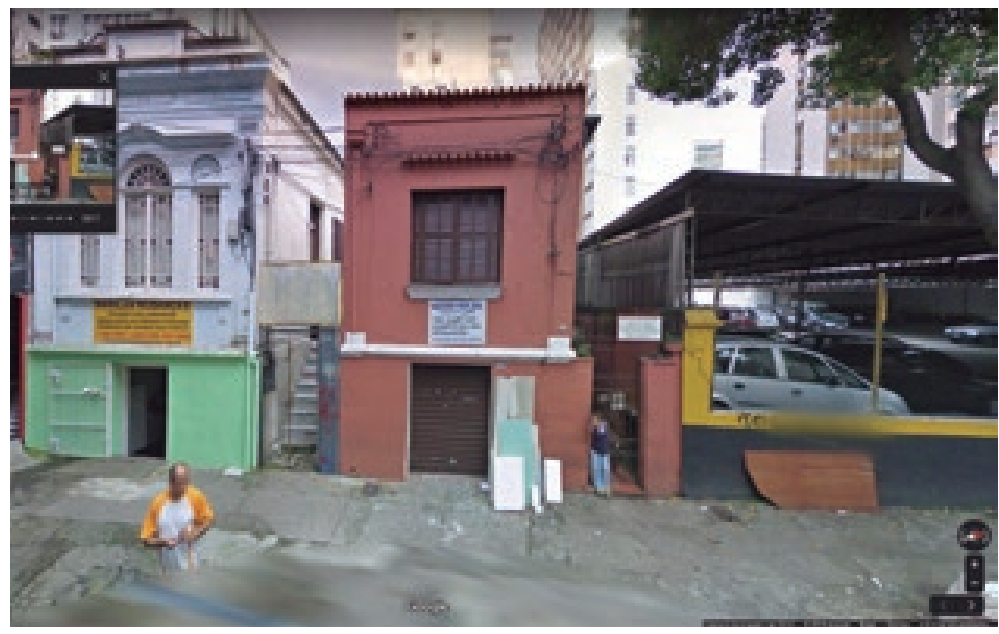

Fig. 3.3.16

Fotografia Rua General Julio Marcondes Salgado, 115 (2010) Google Street View, 2010.

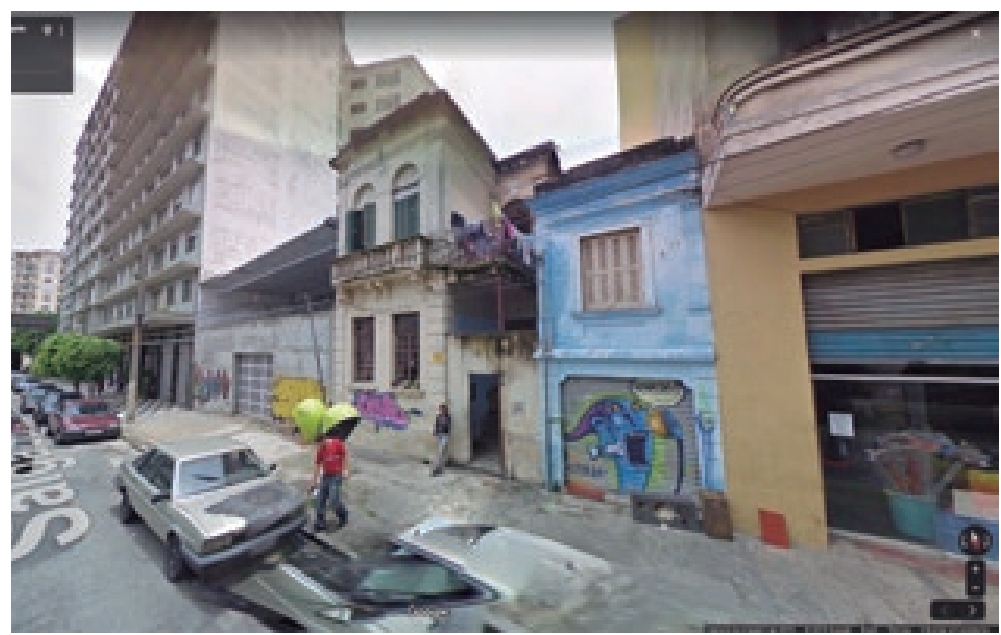



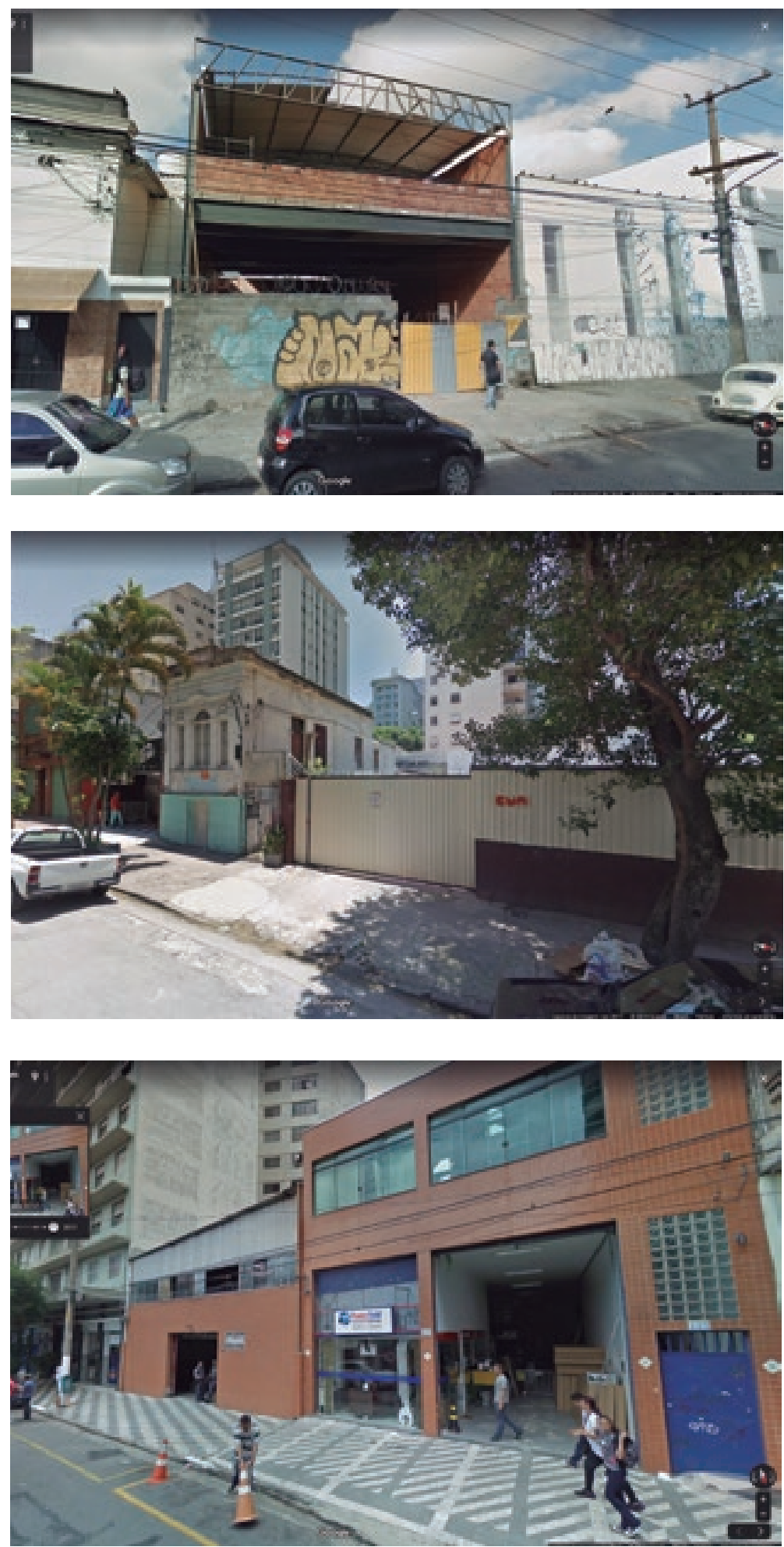

Fig. 3.3.13

Fotografia Rua Barão de Campinas, 573 (2018) Google Street View, 2018.

Fig. 3.3.15

Fotografia Rua Barão de Tatuí, 234 (2014) Google Street View, 2014.

Fig. 3.3.17

Fotografia Rua General Julio Marcondes Salgado, 115 (2017) Google Street View, 2017. 
outra evidência clara sobre isso ${ }^{133}$. Podemos dizer, portanto, que neste levantamento preliminar há sinais da permanência da maioria dos cortiços cadastrados em 2006.

Com base nas fotografias retiradas nesta plataforma podemos realizar outras ponderações sobre a produção do espaço no entorno do Minhocão. Nas primeiras duas imagens, verificamos, por meio de imóvel localizado na Al. Ribeiro da Silva $797-$ datadas de 2010 (fig. 3.3.4) e 2018 (fig. 3.3.5) - a dificuldade de atestar com segurança a situação deste cortiço que no cadastro da SEHAB registrou 41 pessoas morando. Podemos verificar que a placa "aluga-se quarto" não está mais presente, mas não podemos dizer com segurança que não se trata mais de um cortiço. Também é difícil, por meio das imagens, verificar a condição dessa moradia, em quais condições contratuais é ocupada, assim como o perfil das pessoas que nela moram.

Na sequência vemos imagens que datam de 2010 (fig. 3.3.6) e 2018 (fig. 3.3.7) de imóvel localizado na Alameda Glete n. 1058. Na primeira imagem, vemos um "casarão" de início do século $\mathrm{XX}$, no qual foram registradas 21 pessoas morando em situação de cortiço. Na foto seguinte, verificamos que o mesmo foi demolido: o lote que servia ao casarão encontra-se vazio e pintado de cinza. O espaço cinza parece estar sendo utilizado como estacionamento que serve a loja de equipamentos de ar-condicionado que se encontra ao lado, pintada na mesma cor. A situação deste imóvel pode ser verificada de forma muito semelhante em outros dois ${ }^{134}$ imóveis (fig. 3.3.8 a 3.3.11)que a seguir trazemos para ilustrar esta transformação. Em ambos a demolição de sobrados (edificação residencial horizontal) dá lugar a um espaço vazio, à espera por um novo uso, nos três casos pintado de cinza.

133. Nestes 49 edifícios, seria necessária uma série de visitas a campo, incluindo um roteiro de entrevista ou questionário para levantar sua real condição, uma vez que é difícil diferenciar pensões, cortiços, ocupações desorganizadas ou domicílios populares em situação regular apenas por imagens tiradas da rua.

134. Trata-se de imóveis localizados na Avenida Angélica, 41 e na Rua Albuquerque Lins $n$. 350. No primeiro caso, não foram registradas as pessoas que nele habitavam, no segundo foram registradas 39 pessoas morando. 
Na sequência, tratamos de uma transformação análoga, mas aqui já podemos verificar um novo uso ocupando o lote. No primeiro caso (fig. 3.3.12 e fig. 3.3.13), trata-se de um imóvel localizado na rua Barão de Campinas n. 573: a transformação registra o casarão demolido e na sequência um galpão que passa a ocupar este espaço. No segundo caso (fig. 3.3.14 e fig.3.3.17), localizado na rua Barão de Tatuí n. 234, verificamos um sobrado, que é demolido e incorporado a um novo empreendimento residencial, não cadastrado na Embraesp. Trata-se de um lançamento da Construtora Elias Victor Nígri Ltda., incorporadora de alto padrão que lançou historicamente apartamentos acima dos $200 \mathrm{~m}^{2}$ de área privativa com ao menos quatro vagas por unidade. Finalmente, no terceiro caso (fig. 3.3.18 e fig.3.3.19) vemos um casarão desaparecer, e o espaço passa a ser ocupado por um espaço comercial, também de venda de equipamentos de ar condicionado.

Ao tratar das transformações nos espaços anteriormente ocupados por cortiços, ilustramos dois movimentos simultâneos. De um lado, a transformação em curso para além da produção imobiliária de edifícios residenciais, que vimos no item anterior. Vemos um movimento mais amplo de substituição de usos e consequente alteração na paisagem construída, desencadeada por um conjunto difuso de atores. De outro, um processo, mesmo que vagaroso, de expulsão das camadas mais vulneráveis e alteração do perfil popular da região. Por se tratarem de imagens recentes, percebemos que se trata de um processo em curso, que tende a se agravar em face da recente intensificação da produção imobiliária e a gradual elevação dos preços, associada à capitalização das rendas imobiliárias.

A continuação, uma análise realizada em colaboração com o Lab Cidade ${ }^{135}$ de um conjunto de dados relativos a ocupações ${ }^{136}$, remoções, reintegrações de posse e desapropriações, aponta para uma concentração desses processos na porção entre o Elevado e o trilho do trem. Este levantamento (mapa 3.3.7) nos traz a própria disputa pelo espaço travada em instâncias institucionais, outra faceta da

135. Laboratório de pesquisa da Faculdade de Arquitetura e Urbanismo da Universidade de São Paulo (FAU USP).

136. Na legenda do mapa 6, as ocupações estão descritas como "esbulho possessório", o termo jurídico para invasão de terreno ou de edifício alheio. 


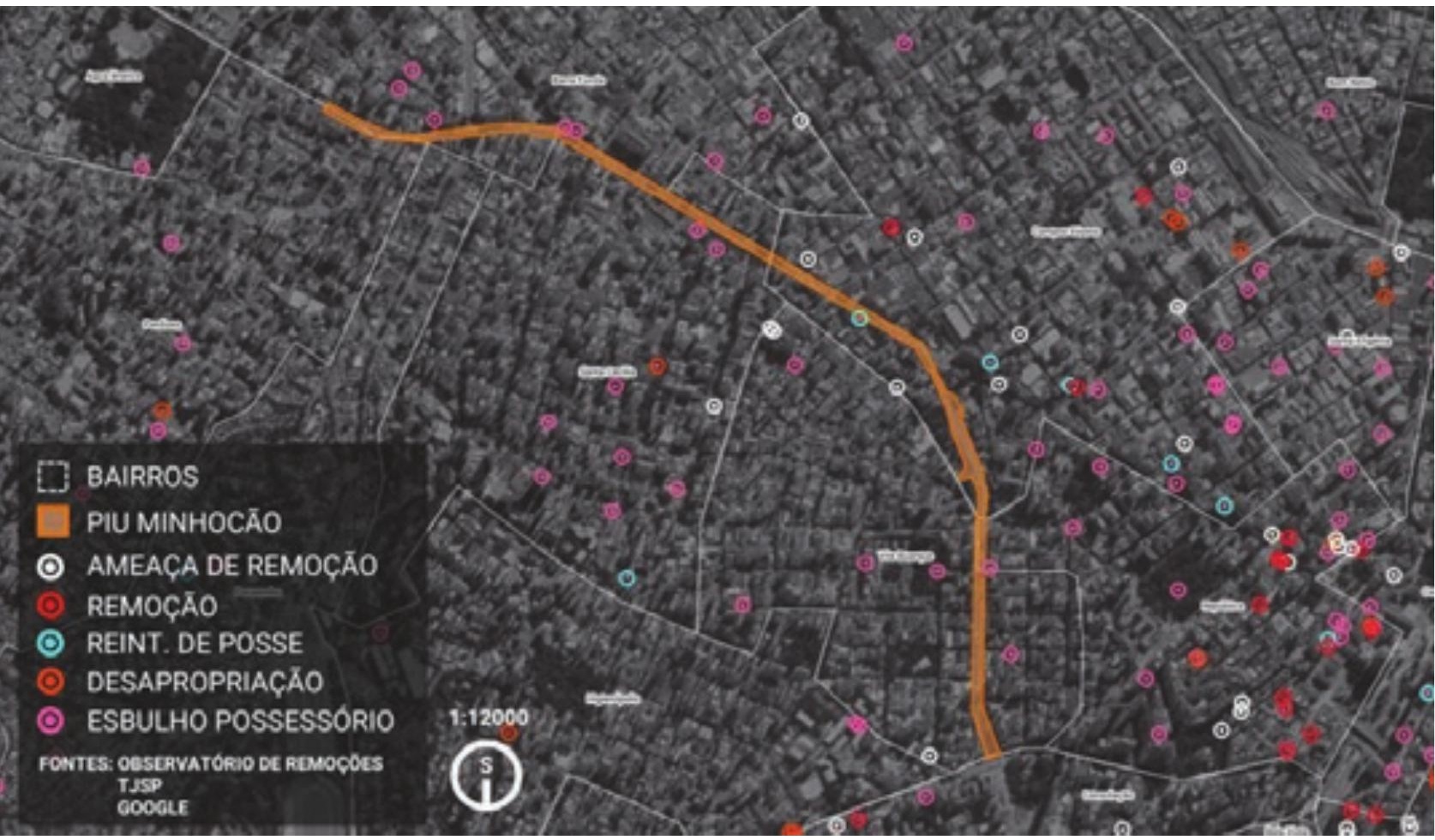

Fig. 3.3.18

Processos de desapropriação, reintegração de posse e ocupações irregulares. LabCidade, 2019. renovação urbana em áreas degradadas que trata de forma direta e institucionalizada da expulsão das populações em situação de maior vulnerabilidade social.

Finalmente e como comentário na busca por reforçar as qualidades populares desta região e marcar a sua permanência, a Rede Paulista de Educação Patrimonial (REPEP) ligada à Universidade de São Paulo (USP), publicou um relatório intitulado Dossiê Participativo Minhocão Contra Gentrificação. Este dossiê identificou e mapeou referências culturais de diversos grupos sociais que fundaram a sua prática no entorno do Elevado, "de forma que seja possível embasar as discussões sobre o direito de permanência dos grupos sociais diversos que ocuparam esse espaço ao longo do tempo" (REPEP, 2019, p.12).

O grupo defende que qualquer transformação no espaço (parque ou demolicação) promoverá a "revalorização espacial" e a consequente expulsão da população de baixa renda. Ele destaca um possível 


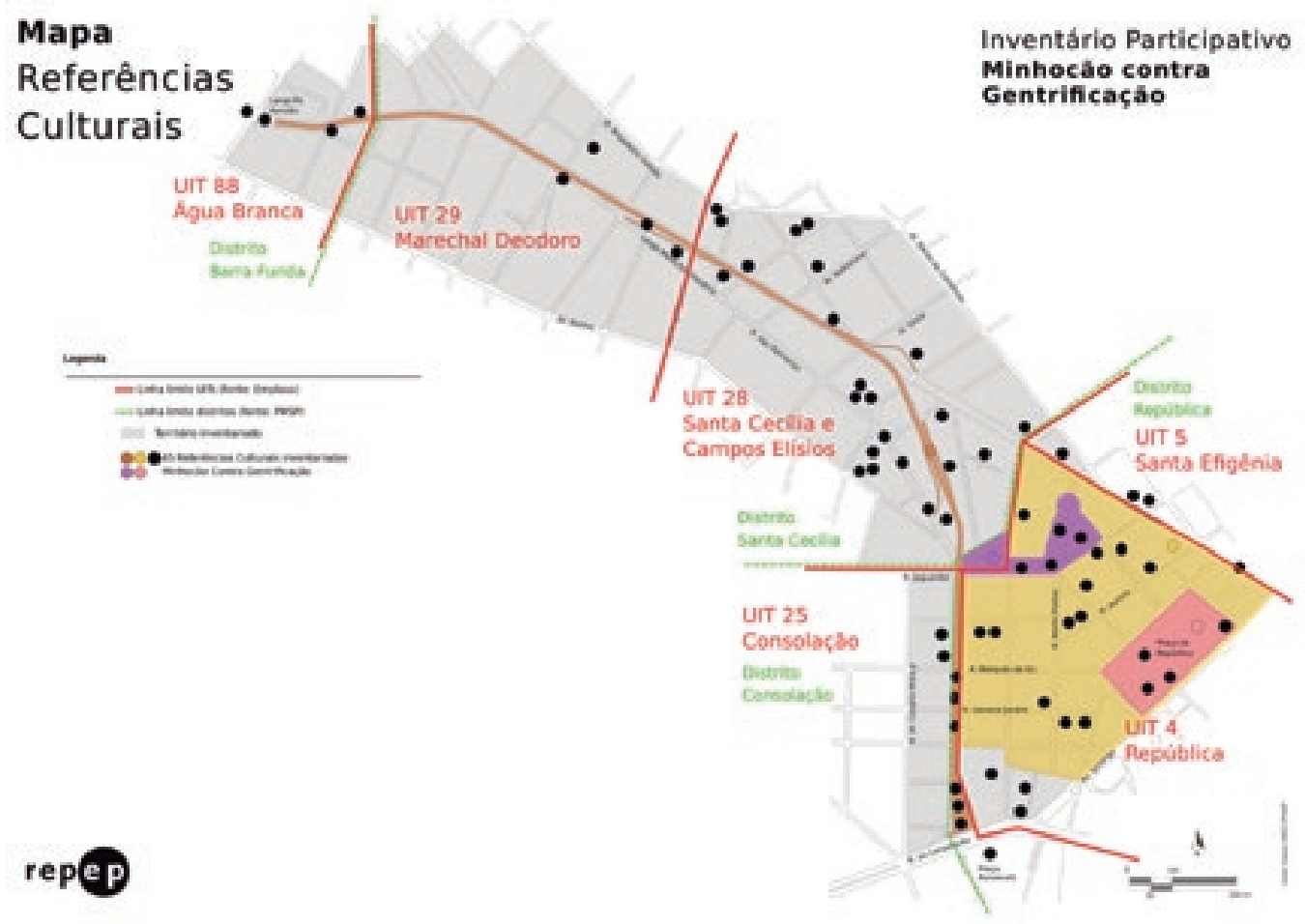

aumento dos aluguéis em 300\% entre 2016 e 2019 "causando risco e perda de referências culturais” (REPEP, 2019, p.13). O relatório nos traz um panorama (fig. 3.3.20) sobre o patrimônio material e imaterial produzido no entorno, "grupos sociais que ressignificam intensamente a região e cuja vida, memória e identidade estão Fig. 3.3.19 Mapa de referências culturais do Inventário Participativo Minhocão contra gentrificação. REPEP, 2019. ligadas ao território" (REPEP, 2019, p.120), celebrações, formas de expressão, saberes que reforçam o espaço como valor de uso sobre o valor de troca.

O dossiê ${ }^{137}$ identificou diferentes grupos sociais envolvidos no território, na busca por levantar sujeitos "em condição mais frágil frente aos efeitos da gentrificação" na "defesa da permanência dos grupos sociais mais vulneráveis no centro". Deste dossiê, que merece análise própria, foram levantados trabalhadores e

137. REPEP. Dossiê do Inventário Participativo Minhocão contra gentrificação. 2019. Grupo de Trabalho Baixo Centro da Rede Paulista de Educação Patrimonial, São Paulo, 2019. 
moradores mais pobres do centro, membros da comunidade LGBT+ (incluindo profissionais do sexo), imigrantes, trabalhadores da cultura e pessoas em situação de rua, além das referências culturais que marcam o território do entorno do Minhocão, aos quais um projeto de intervenção urbana deveria levar em consideração.

Os conflitos iluminados neste item, levantam questões colocadas por Harvey (1982) sobre os conflitos no local de viver do trabalhador, relacionados à produção e uso do ambiente construído. Conforme aponta o autor, se por um lado o capital em geral e os construtores especificamente buscam definir qualidade de vida em termos de mercadorias que podem ser produzidas lucrativamente em certas localidades, por outro, o trabalho luta por definir qualidade de vida apenas em termos dos valores de uso necessários para sua reprodução. A generalização do modo de produção capitalista, a sua sobrevivência, requer que o trabalho seja dominado não apenas no processo e local de produção das mercadorias mas também na esfera do consumo, da qualidade de vida, moldando nela o próprio modo de consumir. De tal forma que a propriedade privada não tributa o trabalho por meio da extração de rendas mas também molda a reestruturação espacial por meio de ferramentas como o Planejamento e o design no sentido da acumulação em detrimento da conservação do ambiente natural e da reprodução da vida destes. Iluminam portanto os limites para o avanço do capital em contraposição à resistência do caráter popular da região, enquanto espaço de reprodução das populações em situação de maior vulnerabilidade. Nesse sentido Brandão (2012) e Rufino (2018) apontam:

\footnotetext{
O movimento da acumulação de capital, sobretudo em sua face homogeneizadora de relações, vai procurar suplantar essa durabilidade das formas, das estruturas, das relações e dos processos preexistentes que soem limitar e dirigir as transformações em curso requeridas por aquele movimento contínuo. Esse é um processo conflitivo e contraditório, que nunca se completa plenamente e "de uma vez por todas..." (Brandão, 2012, p. 53).
} 
A mercantilização e privatização crescente da cidade acaba por elucidar de maneira mais clara uma importante contradição urbana. A cidade consagrada como propriedade passará em última instância a representar um mecanismo (re) produtor de novas desigualdades, subordinando-se à acumulação capitalista em detrimento à reprodução da força de trabalho. Nesse contexto, o Planejamento Urbano, e sua intrínseca relação com a propriedade imobiliária, se revela, por meio de instrumentos específicos, como catalisador da mercantilização da metrópole. Ao centrar sua ação em movimentos de ordenação e coordenação da propriedade e do capital, o Planejamento tem se retirado cada vez mais da efetivação de condições à reprodução da força de trabalho, ou seja, da desmercantilização da cidade (Rufino, 2018, p. 108).

Verificamos ao longo deste capítulo como os novos marcos regulatórios contribuem para colocar em circulação novamente porções do espaço até então à margem deste movimento de mercantilização e valorização imobiliária. Planos que reforçam estas contradições do desenvolvimento capitalista, tanto por meio da delimitação de zonas de incentivo à produção e adensamento construtivo quanto por meio de instrumentos de mobilização de terras e de financiamento público pautados na intensificação desta produção. O verificado avanço da incorporação imobiliária em regiões centrais, antes ditas degradadas e pouco exploradas pelo mercado, certifica a capacidade destes planos de alavancar o avanço do mercado nos espaços onde camadas populares da sociedade se reproduzem.

Mais especificamente sobre o Minhocão o contínuo anúncio de leis, planos e projetos para a sua transformação, principalmente após as discussões do PDE de 2014, contribuem para criar um consenso em torno da necessária transformação do Elevado. Mesmo que discordando enquanto a forma, verificamos como o consenso acaba projetando no horizonte uma imagem virtual desta transformação: o parque. Processo que contribui para a superação dos estigmas históricos sobre a região criando um clima de otimismo que mobiliza novos frequentadores, com alto poder de aquisitivo. 
Conforme vimos, apesar destes projeto terem intervindo pouco em termos efetivos e diretos sobre este espaço, às margens do Elevado a propriedade tem se transformado, capitalizando estas supostas transformações e alavancando processo de espoliação urbana. Verificamos ao longo deste capítulo uma intensificação da produção imobiliária associada à oferta de novos produtos voltados para a locação (de espaços cada vez menores), que reforçam a centralidade das rendas imobiliárias no produto imobiliário. Este processo, que articula interesses monopolísticos, agentes da sociedade civil e do poder público, aproxima a construção de consensos a práticas hegemônicas de controle da produção do espaço. A renovação urbana, enquanto diferenciação espacial e homogeneização das relações de produção, se realiza capitalizando na propriedade as transformações anunciadas pelo poder público antes mesmo que estas aconteçam, alavancando processos de espoliação urbana próprios de desenvolvimento capitalista. 


\section{Considerações finais}

No primeiro capítulo, analisamos as transformações da região do Minhocão ao longo do século XX enquanto determinantes históricas e condicionantes espaciais para a produção do espaço posterior. Por meio de alguns recortes, estudamos ao longo do período a importação de diversos modelos, consagrados internacionalmente, de arquiteturas e urbanismos para validar o desenvolvimento fragmentado da metrópole de São Paulo. Inclui-se nesta análise o adensamento do entorno da Av. São João, que constituiu a chamada Cinelândia Paulista, e a posterior construção da via expressa elevada, então batizada Elevado Costa e Silva.

Verificamos o impacto que o Elevado causou no seu entorno imediato, contribuindo com um movimento mais amplo de "abandono" da região central da cidade, principalmente por parte das camadas abastadas da sociedade e do poder público. Neste processo, por meio de notícias de jornal, verificamos como 
os imóveis contíguos à estrutura sofreram uma desvalorização imediata. Movimento que possibilitou que os mesmos fossem ocupados pela população de baixa renda, que viu na ocupação de imóveis vazios oportunidade solventes de moradia próxima a uma boa rede de serviços básicos; e contribuiu para o processo de popularização do Centro.

A partir da década de 1990, quando o Minhocão passou a ser fechado para o tráfego de veículos motorizados aos domingos, vimos como novas formas de ocupação do espaço passaram a se efetivar sobre o seu tabuleiro de forma mais ou menos espontânea. Vimos como estas formas gradualmente ocuparam a esfera institucional e a tecnocracia estatal, principalmente por meio de eventos oficiais que passaram a se efetivar aqui. A constituição do Minhocão como espaço de lazer tem aproximadamente três décadas, portanto não é nova; o que é novo são os projetos que passaram a ser anunciados a partir do século XXI.

Verificamos no capítulo 2 a publicação de uma série de leis, planos e projetos que inicialmente trouxeram para a esfera institucional estas formas de ocupação espontânea e, posteriormente, passaram a sugerir a transformação desta estrutura. Projetos que pela sua repetição ganharam atenção nos meios de comunicação até se constituírem enquanto consenso, imagens compartilhadas em torno da transformação da estrutura, seja ela qual for. Demonstramos como esta construção (ou persuasão) envolve uma série de atores públicos, coligação de vereadores de diferentes partidos e umas poucas organizações civis, que se debatem sobre especificidades do seu desenho, mas avançam na necessária transformação do espaço.

Constituintes de uma virtualidade, projeção do possível, estes projetos se valem de imagens do passado ou da importação de referências internacionalmente consagradas para criar um consenso em prol da transformação do espaço. O procedimento parece repetir aqueles que vimos ao longo do século XX, agora adaptados a protocolos democráticos: mobilização de arquiteturas e urbanismos no intuito de validar o desenvolvimento fragmentado da metrópole. Virtualidade compatível com o deslocamento 
dos axiomas que regem a acumulação capitalista. Vemos principalmente como a ideia de transformação do Minhocão em parque passa a ser apropriada até mesmo pela publicidade de automóveis, em um momento no qual ganha centralidade a acumulação de capital fictício associado à capitalização da renda imobiliária, provenientes do instituto da propriedade privada, em detrimento do capital valorizado na esfera da produção fabril.

No sentido da efetivação de um programa de intervenções públicas, estes projetos pouco concretizaram seus objetivos, porém à suas margens não observamos a mesma paralisia. Apesar de verificarmos que o mercado imobiliário historicamente produziu de forma regular no entorno do Elevado, de forma diferencial ao longo do seu trajeto; mais recentemente pudemos observar um processo de intensificação da produção. A partir do século XXI, observamos uma série de lançamentos residenciais próximos ao Centro da cidade, produção que a partir da metade da década de 2010 se intensifica, associada a um movimento conjuntural de intensificação da atividade imobiliária na região central.

Produção esta que se diferencia paulatinamente da anterior tanto pela quantidade de empreendimentos lançados em zonas antes pouco exploradas, quanto pelo seu porte em termos de número de unidades e valor geral de vendas. Nestes novos empreendimentos, verificamos transformações tanto na forma de se relacionarem com o entorno quanto na oferta de um novo produto imobiliário: unidades menores que passam de ser comercializadas não como moradia própria, mas como investimento rentável. Nesse sentido verificamos o aumento do número de empreendimentos para locação disponibilizados através de um novo universo de plataformas digitais. Devemos reforçar que o que é novo aqui não é o tamanho da unidade, já que historicamente se produziram unidades pequenas no Centro da cidade, mas a intensificação da produção para locação e a consequente associação a novos negócios financeiros.

Articulamos, portanto, este processo aos efeitos desta virtualidade por meio da observação não do objeto, mas das suas margens. O fio condutor da transformação urbana é o setor da proprieda- 
de que se reproduz aqui, constituído por um número crescente de agentes mais ou menos articulados envolvidos na extração monopolista de retornos. Processo que ganha validade por meio de agentes públicos e organizações da sociedade civil que se articulam para a produção de um consenso: a transformação do espaço. Junto a eles outros grupos ou frações da classe média-alta e alta, que resistem ou não a esta transformação em curso, contribuem por meio da implantação de negócios hipsters para atrair uma nova demanda a esta nova espacialidade, criando um clima local de efervescência e sinergias. A transformação do espaço se constitui então enquanto hegemonia: controle da produção do espaço, do produto socialmente construído.

Em oposição, buscamos por último salientar o caráter popular deste espaço, enquanto espaço para a reprodução dos setores mais vulneráveis da sociedade a fim de iluminar os conflitos que se estruturam em torno deste processo. Problematizamos a visão do poder público de se tratar de um espaço de baixa vulnerabilidade social demonstrando que ele se constitui como fronteira entre dois polos do espectro social, onde um busca se sobrepor ao outro. Elucidamos aqui como a transformação do espaço, que envolve diversos agentes, paulatinamente expulsa aqueles que habitam moradias precárias às suas margens. Pela negação do domínio ao outro, aqui a hegemonia se mostra ferramenta de classe.

Entendemos que o processo de transformação do Minhocão envolve por um lado a recuperação da rua como espaço do encontro. Nesse sentido, espaço enquanto valor de uso, de socialização, de recuperação do tempo (Lefebvre, 199, p.132), local do habitar e do cotidiano; possibilidade de múltiplas apropriações para usos sociais diversos (quiçá libertários). Podemos dizer que desde a década de 1990 este lugar passou a ser palco espontâneo destas utopias, que ampliaram seus horizontes na medida que o horário de fechamento para o tráfego de automóveis aumentou.

Por outro lado ele envolve propriedades que se situam à margem deste movimento: espaços privados que circunscrevem o espaço público. Aqui a transformação do Elevado em parque (re)valori- 
za o seu entorno no sentido da sua mercantilização, negando espaço às pessoas em situação de maior vulnerabilidade. Entendemos portanto como este espaço virtual (abstrato) contribui para a derrubada das barreiras que entravam o movimento espiralar de valorização do capital pela propriedade. Mostramos uma outra faceta da poderosa articulação entre Produção Imobiliária e Planejamento Urbano: aqui o espaço se diferencia reproduzindo as desigualdades do desenvolvimento capitalista.

A transformação da via expressa em parque é um símbolo de que a cidade atual difere daquela que foi no passado. Por um lado a via expressa elevada como resposta a aceleração do deslocamento entre trabalho e moradia, desvalorizou as propriedades posicionadas imediatamente no seu entorno para priorizar o aumento das forças produtivas e o consequente aumento da valorização do capital pelo trabalho na esfera da produção. Por outro, o parque encena seu oposto, como espaço de permanência, substituto da natureza, ele (re)valoriza a propriedade do seu entorno. Visto de perto, ele veicula por meio de uma imagem fragmentada, caleidoscópica, signos que alavancam a acumulação capitalista, ferramentas de controle social e confinamento do habitar. Espaços ditos "degradados" ou "desvalorizados" que se constituem como "fronteiras de expansão da lucratividade" (Smith, 2007) ou "fronteiras infernais da renovação urbana" (Petrella, 2017). A institucionalização do parque, enquanto confinamento e fragmentação da experiência, assim como seu design, a sua geometria abstrata, os seus signos, as suas formas de controle, ameaçam seus horizontes utópicos delegando a produção do espaço aos interesses monopolísticos.

Em suma os projetos do Poder Público se revelam ferramentas para a construção de um consenso que intervém no espaço de forma indireta. Hegemonia com fortes traços de classe que impulsiona o setor da propriedade e seus interesses monopolísticos no controle da produção do espaço para a capitalização da propriedade. Processo este que ameaça a permanência daqueles em situação de maior vulnerabilidade. 


\section{Bibliografia}

ABRAMO, Pedro. La ciudad COM-FUSA. Mercado y la producción de la estructura urbana en las grandes metropolis latinoamericanas. EURE, Santiago, v. 38, pp. 43-59, 2012.

AFFONSO, R. de B. Álvares. Descentralização e reforma do Estado: a Federação brasileira na encruzilhada. Economia e Sociedade, Campinas, n. 14, pp. 127-152, jun. 2000.

ALCÂNTARA, Maurício Fernandes de. "Hipsterização" no centro de São Paulo: consumo, trabalho e produção da cidade. 2019. 174f. Dissertação (Mestrado) - Faculdade de Filosofia, Letras e Ciências Humanas, Universidade de São Paulo, São Paulo, 2019.

ANELLI, Renato L. S.; SEIXAS, Alexandre R.. O peso das decisões: o impacto das redes de infraestrutura no tecido urbano. In: ARTIGAS, Rosa; CASTRO, Ana C.; MELLO, Joana; (orgs). Caminho do Elevado: memória e projetos. São Paulo: Imprensa Oficial do Estado de São Paulo, 2008.

ARANTES, Paulo; MARICATO, Erminia; VAINER, Carlos. A cidade do pensamento único. 8a ed. Petrópolis: Vozes, 2013.

ARANTES, Pedro. 0 ajuste urbano: as políticas do Banco Mundial e do BID para as cidades. Revista Pós, n. 20, 2006.

ARRETCHE, Marta T. S. O sistema de proteção social brasileiro: em direção a um modelo descentralizado. São Paulo: São Paulo em Perspectiva, v. 11, n. 3. 1997. 
ARTIGAS, Rosa; CASTRO, Ana Claudia; MELLO, Joana Mello; (orgs). Caminho do Elevado: memória e projetos. São Paulo: Imprensa Oficial do Estado de São Paulo, 2008.

ASSUNÇÃO, Eduardo L. L. Minhocão e arredores: construção, degradação e resiliência (1970-2016). Dissertação (Mestrado em Arquitetura e Urbanismo) - Universidade Presbiteriana Mackenzie, São Paulo, 2016.

BACHUR, João P.. Federalismo fiscal, atribuições fiscais constitucionais e equalização regional: EUA, Alemanha e Brasil em perspectiva comparada. Brasília: Revista do Serviço Público Brasília, n.56, pp. 377-401, 2005

BERCOVICI, Gilberto; MASSONETTO, Luis Fernando. A constituição dirigente invertida: a blindagem da constituição financeira e a agonia da constituição econômica. Coimbra: Boletim de ciências econômicas, vol. XLIX, 2006.

BIDOU-ZACHARIANSEN, Catherine.; NICOLAS, Daniel H.; D'Arc, Hélene R. (orgs.). De volta à cidade: dos processos de gentrificação às políticas de "revitalização" dos centros urbanos. São Paulo: Annablume, 2006.

BONDUKI, Nabil (org.). A luta pela reforma urbana no Brasil: Do seminário de habitação e Reforma Urbana ao Plano Diretor de São Paulo. São Paulo: Instituto Casa da Cidade, 2017.

BONDUKI, Nabil; ROSELLA, Rossetto. A reforma urbana no Plano Diretor Estratégico de São Paulo de 2002 e 2014. in BONDUKI, Nabil (org.). A luta pela reforma urbana no Brasil: Do seminário de habitação e Reforma Urbana ao Plano Diretor de São Paulo. São Paulo: Instituto Casa da Cidade, 2017.

BRANDÃO, Carlos A. Território e desenvolvimento: as múltiplas escalas entre o local e o global. Campinas: Editora Unicamp, 2012. 
CAMPOS, Candido M. Construção e desconstrução do centro paulistano. Ciência e Cultura, São Paulo, n. 2 (ano 56), 2004.

CAMPOS, Candido M. Eixo da ambiguidade: a região da Avenida São João nas inversões do tempo. in ARTIGAS, Rosa; CASTRO, Ana Claudia; MELLO, Joana Mello; (orgs). Caminho do Elevado: memória e projetos. São Paulo: Imprensa Oficial do Estado de São Paulo, 2008.

CARMAGNANI, Maria Pia Quagliato Egreja. Retornando ao centro: a nova produção imobiliária no distrito da República. 2019. Dissertação (Mestrado em Planejamento Urbano e Regional) - Faculdade de Arquitetura e Urbanismo, Universidade de São Paulo, São Paulo, 2019.

CASTRO, Carolina Maria Pozzi de. A explosão do autofinanciamento na produção da moradia em São Paulo nos anos 90. Tese (Doutorado) - Faculdade de Arquitetura e Urbanismo, Universidade de São Paulo, São Paulo, 1999.

D'ALMEIDA, Carolina H. Como o urbanismo tem sido operado em processos de concessão - A aplicação dos Projetos de Intervenção Urbana (PIUs) em São Paulo. In: Anais do XVIII ENANPUR. 2019.

D'ELBOUX, Roseli M. M. Joseph-Antoine Bouvard no Brasil: Os Melhoramentos de São Paulo e a criação da Companhia City: ações interligadas. Tese (Doutorado em Planejamento Urbano e Regional) - Faculdade de Arquitetura e Urbanismo da Universidade de São Paulo, 2015.

DE MATTOS, Carlos A. Globalização, negócios imobiliários e transformação urbana. Nueva Sociedad: Caracas: n.212, novembro-dezembro de 2007. 
FERREIRA, Pedro B. S. A Avenida de mil vias: conflito, contradição e ambivalência na modernização de São Paulo (18901920). Dissertação (Mestrado em História e Fundamentos da Arquitetura e Urbanismo) - Faculdade de Arquitetura e Urbanismo da Universidade de São Paulo, 2016.

FIX, Mariana. Financeirização e transformações recentes no circuito imobiliário no Brasil. Tese de doutorado, Campinas, UNICAMP, 2011.

FONSECA, Nuno de Azevedo. A arquitetura do mercado imobiliário e seu processo de produção na cidade de São Paulo. Tese (Doutorado) - Faculdade de Arquitetura e Urbanismo da Universidade de São Paulo, 2000.

GOTTDIENER, Mark. A produção social do espaço urbano. $2 a$ ed. São Paulo: Editora da Universidade de São Paulo, 2016.

HARVEY, David. O trabalho, o capital e o conflito de classes em torno do ambiente construído nas sociedades capitalistas avançadas. Espaço e debates, v.6, pp. 7-14, 1982.

HARVEY, David. Do gerenciamento ao empresariamento: a transformação da administração urbana no capitalismo tardio São Paulo, Espaço e Debates, nº 39, 1996.

HARVEY, D. A produção capitalista do espaço. São Paulo: Annablume, 2005.

HARVEY, David. Os limites do capital. 1a ed. São Paulo: Boitempo, 2013.

HARVEY, David. A recusa de Marx da teoria de valor. Trad.: Carine Botelho Previatti. Geousp. Espaço e tempo (Online), v.22, n. 1, p. $257-264,2018$.

ITDP Brasil. Guia de Implementação de Políticas e Projetos de DOTS. ITDP Brasil, 2017. Disponível em:<http://itdpbrasil.org.br/ wp-content/uploads/2017/12/ITDP-BR-DU-GUIADOTS-V2.3.pdfs. 
KALICHMAN, Beatriz F. Vendendo studios no centro das quitinetes: o caso da República pensado a partir da gentrificação e a gentrificação pensada a partir do caso da República. Dissertação (Mestrado em Planejamento Urbano e Regional), Rio de Janeiro: UFRJ - Universidade Federal do Rio de Janeiro, 2019.

KARA JOSÉ, Beatriz. A popularização do centro de São Paulo: um estudo de transformações ocorridas nos últimos vinte anos. Dissertação (Doutorado em Planejamento Urbano e Regional) - Faculdade de Arquitetura e Urbanismo da Universidade de São Paulo, 2012.

KWAK, André. Um entreato progressista na ocupação do espaço público da cidade. Revista pós, FAUUSP. São Paulo, v. 25, n. 46, pp.12-31, mai-ago 2018.

KOWARICK, Lucio. A espoliação urbana. Rio de Janeiro: Paz e Terra, 1979.

LE CORBUSIER. Precisões sobre um estado presente da arquitetura e do urbanismo. São Paulo: Cosac \& Naify, 2004.

LEFEBVRE, Henri. A revolução urbana. Belo Horizonte: Ed. UFMG , 1999.

LENCIONI, Sandra. Reestruturação imobiliária: uma análise dos processos de concentração e centralização do capital no setor imobiliário. Revista EURE - Revista De Estudios Urbano Regionales, 40(120), 2014.

LENCIONI, Sandra. Metrópole e sua lógica capitalista atual face ao regime de acumulação patrimonial. Mercator, Fortaleza, Consequência, v. 14, n.4, Número Especial pp. 149-158, dez. 2015.

LORES, Raul J. São Paulo nas alturas: a revolução modernista da arquitetura e do mercado imobiliário nos anos 1950 e 1960. São Paulo: Três Estrelas, 2017. 
MARQUES, Rosa M.; NAKATANI, Paulo. A finança capitalista: a contribuição de François Chesnais para a compreensão do capitalismo contemporâneo. Salvador: Anais do XXXVI Encontro Nacional de Economia [Proceedings of the 36th Brazilian Economics Meeting].

MARX, Karl. O capital. 2a ed. São Paulo: Nova Cultura, 1985. v. 1, capítulo 1.

MARX, Karl. O capital. 2a ed. São Paulo: Nova Cultura, 1986. v. 5, capítulo 46.

MARX, Karl. Salário, Preço e Lucro. In.: Manuscritos econômico-filosóficos e outros textos escolhidos. 4a Ed. São Paulo: Nova Cultura, 1988. V. 2.

MILES, Mike. E.; NETHERTON, Laurence M.; SCHMITZ, Adrienne. Real Estate Development - Principle and process. $5 \mathrm{a}$ ed. Washington, DC: Urban Land Institute, 2015.

NOBRE, Eduardo A. C. Reestruturação econômica e território: a expansão recente do terciário na marginal do rio Pinheiros. Tese (Doutorado) - Faculdade de Arquitetura e Urbanismo da Universidade de São Paulo, 2000.

NOBRE, Eduardo A. C. Políticas urbanas para o centro de São Paulo: renovação ou reabilitação? Avaliação das propostas da prefeitura do município de São Paulo de 1970 a 2004. Pós. Revista do Programa de Pós-Graduação em Arquitetura e Urbanismo da FAUUSP, v. 0, pp. 214-231, 2009.

NOBRE, Eduardo A. C. A atuação do poder público na construção da cidade de São Paulo: a influência do rodoviarismo no urbanismo paulistano. Anais. Vitória: UFES, 2010.

OTERO, Guido D. Representações da metrópole: um estudo sobre o preço da terra. Trabalho final de graduação - Faculdade de Arquitetura e Urbanismo da Universidade de São Paulo, 2012. 
PAULANI, Leda M. Acumulação e rentismo: resgatando a teoria da renda de Marx para pensar o capitalismo contemporâneo. Revista de Economia Política, vol. 36 (3)/144, pp. 514-535, 2016.

PEREIRA, Paulo C. X. Espaço, técnica e construção: o desenvolvimento das técnicas construtivas e a urbanização do morar em São Paulo. São Paulo: Nobel. 1988.

PEREIRA, Paulo C.X. Dinâmica imobiliária e Metropolização: a nova lógica do crescimento urbano em São Paulo. Scripta Nova. Revista electrónica de geografía y ciencias sociales. Barcelona: Universidad de Barcelona, 1 de agosto de 2005. v. 4, n. 194.

PEREIRA, Paulo C.X.; RUFINO, M. Beatriz C. Segregação e produção imobiliária na transformação da metrópole latinoamericana: um olhar a partir da cidade de São Paulo. In: LENCIONI, Sandra (org.). Transformações sócio-territoriais nas metrópoles de Buenos Aires, São Paulo e Santiago. 1ed. São Paulo: Universidade de São Paulo, pp. 65-84, 2011.

PEREIRA, Paulo C.X. Preço e valor na financeirização da produção do espaço. In: FERREIRA, Alvaro ; RUA, João; DE MATTOS, Regina C. (org.). O espaço e a metropolização: cotidiano e ação. 1ed. Rio de Janeiro: Consequência editora,cap. 7, pp. 171-211, 2017.

PEREIRA, Paulo C. X. (org.). Imediato, global e total na produção do espaço: a financeirização da cidade de São Paulo no Século XXI. São Paulo: FAUUSP, 2018.

PETRELLA, Guilherme. A fronteira infernal da renovação urbana em São Paulo: região da Luz no século XXI. Dissertação (Doutorado em Planejamento Urbano e Regional) - Faculdade de Arquitetura e Urbanismo da Universidade de São Paulo, 2017.

POLANYI, Karl. A grande transformação: as origens da nossa época. 2ed. Rio de Janeiro : Elsevier, 2012, 2000. 
REPEP. Dossiê do Inventário Participativo Minhocão contra gentrificação. 2019. Grupo de Trabalho Baixo Centro da Rede Paulista de Educação Patrimonial, São Paulo, 2019.

ROYER, Luciana. Financeirização da Politica Habitacional: limites e perspectivas. Tese (Doutorado) - Faculdade de Arquitetura e Urbanismo, Universidade de São Paulo, São Paulo, 2009.

RUFINO, M. Beatriz C. A incorporação da metrópole: centralização do capital no imobiliário e nova produção do espaço em Fortaleza. 2012. Tese (Doutorado) - Faculdade de Arquitetura e Urbanismo, Universidade de São Paulo, São Paulo, 2012.

RUFINO, M. Beatriz C. Reestruturação do setor imobiliário e mudanças no padrão espacial de reprodução do capital: a produção imobiliária como elemento central na reconfiguração das cidades brasileiras. In: Anais do XV Encontro da ANPUR ENANPUR, 2013.

RUFINO, M. Beatriz C. A produção imobiliária como chave de interpretação da produção do espaço: considerações sobre a forma incorporação e o processo de metropolização. In: PEREIRA, Paulo C. X. (org.). Produção imobiliária e reconfiguração da cidade contemporânea.. 1ed. São Paulo: FAU-USP, v. 01, pp. 105-122, 2017.

RUFINO, M. Beatriz C. Financeirização do imobiliário e transformações na produção do espaço. In: FERREIRA, Alvaro ; RUA, João; DE MATTOS, Regina C. (org.). O espaço e a metropolização: cotidiano e ação. 1ed. Rio de Janeiro: Consequência editora, cap. 8, pp. 212-240, 2017.

RUFINO, M. Beatriz C. Do Zoneamento às Operações Urbanas consorciadas: planejamento urbano e produção imobiliária na mercantilização do espaço em São Paulo (1970-2017). in PEREIRA, Paulo C. X. (org.). Imediato, global e total na produção do espaço: a financeirização da cidade de São Paulo no Século XXI. São Paulo: FAUUSP, 2018. 
SANFELICI, Daniel. Financeirização e a produção do espaço urbano no Brasil: uma contribuição ao debate. Eure, v. 39 (118), pp.27-46, 2013.

SANFELICI, Daniel. La industria financiera y los fondos inmobiliarios en Brasil: lógicas de inversión y dinámicas territoriales. ECONOMÍA, SOCIEDAD Y TERRITORIO, p. 367, 2017.

SCHOR, S. M; TEIXEIRA, R. A. O mercado de imóveis e os instrumentos urbanísticos para revitalização do centro de São Paulo. Relatório de consultoria da pesquisa do Observatório do Uso do Solo e da Gestão Fundiária do Centro de São Paulo. São Paulo: LABHAB/FAUUSP; Lincoln Institute of Land Policy, 2006.

SHIMBO, Lucia. O aquecimento imobiliário e o mercado de habitação na área central de São Paulo (2001-2010). EURE, Santiago, v. 39, pp. 215-235, 2013.

SILVA, Helena M. B. (cord.). Oportunidades e limites para a produção de habitação social no centro de São Paulo. Lincoln Institute of Land Policy, 2007.

SILVA, Helena M. B. Transformações no quadro imobiliário do centro de São Paulo no início dos anos 2000. Em PEREIRA, Paulo Cesar Xavier (org.). Negócios Imobiliários e transformações sócioterritoriais em cidades da América Latina. São Paulo: FAUUSP, 2011.

SMITH, Neil. Gentrificação, a fronteira e a reestruturação do espaço urbano. Espaço e Tempo, São Paulo, № 21, pp.15-31, 2007.

TOLEDO, Benedito L. São Paulo: três cidades em um século. 2a Ed. São Paulo: Duas cidades, 1983.

TOLEDO, Benedito L. Prestes Maia e as origens do Urbanismo Moderno em São Paulo. São Paulo: Empresa das artes, 1996. 
TONE, Beatriz B. Notas sobre a valorização imobiliária em São Paulo na era do capital fictício. Tese (Doutorado) - Faculdade de Arquitetura e Urbanismo da Universidade de São Paulo São Paulo, 2010.

TOPALOV, Christian. Os saberes sobre a cidade: tempos de crise?. In: Espaço e Debates no 34 Ano XI, pp. 28-38, 1991.

VILLAÇA, Flávio. Espaço intra-urbano no Brasil. São Paulo: Studio Nobel: FAPESP. Lincoln Institute, 1998.

ZUKIN, Sharon. Paisagens urbanas pós-modernas: mapeando cultura e poder. in ARANTES, A. O espaço da diferença. Campinas, Papirus, 2000.

SECRETARIA DE DESENVOLVIMENTO URBANO DA CIDADE DE SÃO PAULO (SMDU). O que está sendo lançado no Centro de São Paulo?. Informes Urbanos, São Paulo, n.34, agosto, 2018. Disponível em: <www.prefeitura.sp.gov.br/cidade/secretarias/ upload/Informes_Urbanos/IU_Centro2_2018_2.pdf>. Acesso em: 13 fev. 2020.

\section{Jornais e revistas}

AGÊNCIA ESTADO. "Depois de 30 anos, aumenta população no centro de SP." São Paulo, 28 de abril de 2011. Disponível em: <http://www.estadao.com.br/noticias/geral,depois-de-30-anosaumenta-populacao-no-centro-de-sp,711954 >. Acesso em: 07 fev. 2020.

ASSIS, Tatiane, et al. "São Paulo do futuro: o que esperar da metrópole nos próximos anos." Veja São Paulo, 25 de janeiro de 2019. Disponível em: <https://vejasp.abril.com.br/cidades/ sao-paulo-do-futuro/>. Acesso em: 07 fev. 2020.

DE CASTRO, Letícia. Mercado em reforma. Folha de S. Paulo, 25 de abril de 2010, caderno classificados imóveis 1 . 
ÉPOCA NEGÓCIOS. Cyrela cria nova marca para voltar ao Minha Casa Minha Vida após 6 anos. 28 de setembro de 2018. Disponível em: <www.epocanegocios.globo.com/Empresa/noticia/2018/09/ epoca-negocios-cyrela-cria-nova-marca-para-voltar-ao-minhacasa-minha-vida-apos-6-anos.html>. Acesso em: 15 fev. 2020.

EXAME. Construtora Vitacon vai investir $\mathrm{R} \$ 1,5 \mathrm{bi}$ em parceria com fundo. 19 de novembro de 2019.Disponível em: <www. exame.abril.com.br/negocios/construtora-vitacon-vai-investir-r15-bi-em-parceria-com-fundo/>. Acesso em: 13 fev. 2020.

EXAME. "Esta empresa de residência estudantil está transformando as repúblicas". Disponível em: <www.exame.abril.com.br/ pme/esta-empresa-de-residencia-estudantil-esta-transformando-as-republicas/>. Acesso em: 12 fev. 2020.

FOLGATO, Marisa. "Demonte pode ser em partes, começando pela São João." O Estado de S. Paulo, 18 ago. 2005.

FOLHA DE S. PAULO. "Minhocão fecha às 21 h30 e abre às 6h30". São Paulo, 24 de novembro de 1989, caderno cidades.

FOLHA DA MANHÃ. "Venda de imóveis permanece em alta." São Paulo, 21 de julho de 1957, caderno assuntos especializados II.

FONSECA, Mariana. Esta empresa de residência estudantil está transformando as repúblicas. Exame, 28 de setembro de 2019. Disponível em: <www.exame.abril.com.br/pme/esta-empresa-de-residencia-estudantil-esta-transformando-as-republicas/>. Acesso em: 12 fev. 2020.

LACERDA, Fernanda. Novos negócios hipster valorizam imóveis do centro de São Paulo. Folha de S. Paulo, 27 de novembro de 2019. Disponível em: <www.folha.uol.com.br/mercado/2019/11/ novos-negocios-hipster-valorizam-imoveis-do-centro-de-sao-paulo.shtml>. Acesso em: 13 fev. 2020. 
MOURA, Eduardo. Apês compactos no centro de São Paulo estão no radar de jovens, recém-casados e apps de aluguel. Folha de S. Paulo, 31 de agosto de 2018. Disponível em: <www.folha. uol.com.br/saopaulo/2018/08/1980372-apes-compactos-nocentro-de-sao-paulo-estao-no-radar-de-jovens-recem-casados-e-apps.shtml>. Acesso em: 19 fev. 2020.

NOMURA, Leandro. Van e Horta entram na conta do condomínio. Folha de S. Paulo, 28 de agosto de 2016, caderno "sobre morar", p. 3.

O ESTADO DE S. PAULO. Vias elevadas, a nova mania. São Paulo, 23 de setembro de 1969.

O ESTADO DE S. PAULO. Elevado o triste futuro da avenida. 01 de dezembro de 1970.

PAMPLONA, Patrícia; BRANT, Danielle. A Vivenda é uma empresa de reforma voltada para o público de baixa renda que em 2018 captou $R \$ 5$ milhões na emissão de debêntures de "impacto social". Folha de S. Paulo, 26 de março de 2018.Disponível em: <www.folha.uol.com.br/empreendedorsocial/2018/03/1962211-titulo-financeiro-banca-reforma-em-favela>. Acesso em: 13 fev. 2020.

PFEIFER, Ismael. 'Cicatriz', Minhocão inibe empreendimentos ao seu redor. Folha de S. Paulo, 20 de outubro de 2015. Disponível em: <http://especial.folha.uol.com.br/2015/morar/ centro-paulista/2015/10/1696298-cicatriz-minhocao-inibe-empreendimentos-ao-seu-redor.shtml>. Acesso em: 19 fev. 2020.

PINHO, Flávia G.. Ainda no papel, renovação do Minhocão já atrai empreendimentos. Folha de S. Paulo, 02 de junho de 2019. Disponível em: <www.folha.uol.com.br/sobretudo/ morar/2019/06/1988019-renovacao-do-minhocao-ja-atrai-empreendimentos.shtml>. Acesso em: 15 fev. 2020. 
QUINTÃO, Chiara. Mitre monta FIP para moradias estudantis. Valor, 13 de maio de 2019. Disponível em: <www.valor.globo. com/empresas/noticia/2019/05/13/mitre-monta-fip-para-moradias-estudantis.ghtml>. Acesso em: 13 fev. 2020.

RODRIGUES, Renata H. Novos empreendimentos fazem as pazes com o Minhocão. Folha de S. Paulo, 24 de setembro de 2017. Disponível em: <www.folha.uol.com.br/ sobretudo/morar/2017/09/1921062-novos-empreendimentos-fazem-as-pazes-com-o-minhocao.shtml>. Acesso em: 15 fev. 2020.

SANCHEZ, Leonardo. Boom de bares, restaurantes e apês redesenha região do centro conhecida como Nova República. Folha de S. Paulo, 31 de agosto de 2018. Disponível em: <www.folha. uol.com.br/saopaulo/2018/08/1980484-boom-de-bares-res taurantes-e-apes-redesenha-regiao-do-centro-conhecida-como-nova-republica.shtml>. Acesso em: 19 fev. 2020.

SANCHES, Valdir. "Minhocão no chão, por R\$ 80 milhões." O Estado de S. Paulo, 18 de agosto de 2005.

VALOR INVESTE. Vitacon e Easynvest se unem para transformar compactos em fundos. 06 de setembro de 2019.Disponível em: <www.valorinveste.globo.com/produtos/fundos-imobiliarios/ noticia/2019/09/06/vitacon-e-easynvest-se-unem-para-transformar-compactos-em-fundos.ghtml>. Acesso em: 13 fev. 2020.

VEJA SP. Comissão da Câmara Municipal aprova fim do Minhocão. 5 de dezembro de 2016. Disponível em: <www.vejasp. abril.com.br/cidades/comissao-da-camara-sao-paulo-aprovafim-do-minhocao>. Acesso em: 02 fev. 2020.

YURI, Débora. Reocupação da região por jovens gera onda de aumento de preços. Folha de S. Paulo, 01 de maio de 2016. Disponível em: <www.especial.folha.uol.com.br/2016/morar/ paulista-centro/2016/05/1766342-reocupacao-da-regiao-porjovens-gera-onda-de-aumento-de-precos. shtml>. Acesso em: 15 fev. 2020. 


\section{Sites}

ACUPUNTURA URBANA: MAPEAMENTO AFETIVO. Disponível em: <wWw.acupunturaurbana.com.br/servicos/mapeamento-afetivo>. Acesso em: 15 fev. 2020.

ANDRADE, Juliana. Conheça o Coletivo Voodoohop. Guia da Semana, 20 de fevereiro de 2014. Disponível em: <https://www. guiadasemana.com.br/turismo/noticia/conheca-o-coletivo-voodoohop>. Acesso em: 09 fev. 2020.

CAIO MIRANDA CARNEIRO. Disponível em: <www.caiomirandacarneiro.com.br>. Acesso em: 03 fev. 2020.

C MARA MUNICIPAL DE SÃO PAULO: JOSÉ PÓLICE NETO. Disponível em: <www.saopaulo.sp.leg.br/vereador/jose-police-neto/>. Acesso em: 03 fev. 2020.

CIDADE DE SÃO PAULO. Projeto Triângulo SP vai revitalizar Centro Velho de São Paulo. 27 de dezembro de 2018. Disponível em: <www.prefeitura.sp.gov.br/cidade/secretarias/obras/noticias/?p=269418>. Acesso em: 19 fev. 2020.

CIDADE DE SÃO PAULO. "Espaços no Centro da cidade." Disponível em: <www.capital.sp.gov.br/noticia/espacos-no-centro-da-cidade-ganham-intervencoes>. Acesso em: 31 jan. 2020.

CIDADE DE SÃO PAULO. Espaços no centro da cidade ganham intervenções urbanas temporárias. 26 de setembro de 2014. Disponível em: <www.capital.sp.gov.br/noticia/espacos-no-centro-da-cidade-ganham-intervencoes>. Acesso em: 31 jan. 2020.

COMOLATTI, Athos; LEVY, Wilson; POSER, Paulo von. Cidade e democracia: Um estudo de caso da Associação Parque Minhocão. Vitruvius, fevereiro de 2014. Disponível em: <www.www. vitruvius.com.br/revistas/read/minhacidade/14.163/5051>. Acesso em: 02 fev. 2020. 
COMOLATTI, Athos; et al. O Parque Minhocão e a alma da cidade. Vitruvius, maio de 2014. Disponível em: <www.www.vitruvius.com.br/revistas/read/minhacidade/14.166/5154>. Acesso em: 02 fev. 2020.

COMOLATTI, Athos. Como o Minhocão me transformou em um ativista acidental. Esquina, 22 de dezembro de 2017 Disponível em: <www.esquina.net.br/2017/12/22/como-o-minhocao-me-transformou-em-um-ativista-acidental/>. Acesso em: 02.fev. 2020.

COSTA, José E. "Somos uma empresa de bytes e não de tijolos", diz Alexandre Frankel, da Vitacon. Startse, 29 de janeiro de 2019. Disponível em: <www.startse.com/noticia/empreendedores/60233/quem-e-alexandre-frankel-da-vitacon>. Acesso em: 13 fev. 2020.

CYRELA. Comunicado ao mercado. 10 de abril de 2017. Disponível em: <www.cyrela.globalri.com.br/upload/ files/2758_Cyrela-Comunicado-ao-Mercado-Parceria-MAC-x-CBR-10.04.2017.pdf>. Acesso em: 13 fev. 2020.

DARK MATTER LABORATORIES. A Smart Commons. 13 de setembro de 2019. Disponível em: <www. provocations. darkmatterlabs.org/a-smart-commons-528f4e53cec2>. Acesso em: 19 fev. 2020.

GUIA DA SEMANA. Conheça o Coletivo Voodoohop. Disponível em: <https://www.guiadasemana.com.br/turismo/noticia/conheca-o-coletivo-voodoohop>. Acesso em: 09 fev. 2020.

HARKOT, Marina K.; OTERO, Guido D.; SANTORO, Paula. A invisibilidade dos mais pobres no PIU Minhocão. LabCidade, 4 de setembro de 2019. Disponível em: <http://www.labcidade.fau. usp.br/a-invisibilidade-dos-mais-pobres-no-piu-minhocao/>. Acesso em: 03.fev.2020. 
INGAÍ. Disponível em: <www.ingai.com.br>. Acesso em: 02 fev. 2020.

Ilion Partners. Disponível em: <www.ilionpartners.com>. Acesso em: 02 fev. 2020.

LEVY, Wilson. Esfera pública, interesse público e o Parque Minhocão. Vitruvius, fevereiro de 2014. Disponível em: <www. www.vitruvius.com.br/revistas/read/arquitextos/14.165/5086>. Acesso em: 02 fev. 2020.

MITRE REALTY: SHARE STUDENT LIVING. Disponível em: <wWW. mitrerealty.com.br/grupo-mitre/share-student-living.php>. Acesso em: 13 fev. 2020.

MMC INVESTIMENTOS. Disponível em: <wWw.mmcinvestimentos.com.br>. Acesso em: 02 fev. 2020.

PORTAL HABITA SAMPA. Disponível em: <www.habitasampa>. Acesso em: 07 fev. 2020.

PORTAL VGV. You, Inc: Fundador e ex-sócio da Even lança incorporadora focada na classe média e econômica com diferencial no atendimento ao cliente. 29 de Setembro de 2010. Disponível em: <www.portalvgv.com.br/site/you-inc-fundador-e-ex-socio-da-even-lanca-incorporadora-focada-na-classe-media-e-economica-com-diferencial-no-atendimento-ao-cliente>. Acesso em: 13 fev. 2020.

RANKING EMBRAESP DE INCORPORADORAS DA RMSP. Ano de base 2018. Disponível em: <www.embraesp.com.br/wp-content/ uploads/2019/06/Rankings-Incorporadoras-2018.pdf>. Acesso em: 02 fev. 2020.

SHARE STUDENT LIVING. Disponível em: <www.sharesl.com. br>. Acesso em: 13 fev. 2020.

VITACON. Disponível em: <www.vitacon.com.br/capital/ quem-somos/>. Acesso em: 13 fev. 2020. 
VIVA O CENTRO: Programa Ações Locais. Disponível em: <www. vivaocentro.org/programaacoeslocais>. Acesso em: 02 fev. 2020.

\section{Legislação}

BRASIL. Lei n. 10.257, de 10 de julho de 2001. Regulamenta os arts. 182 e 183 da Constituição Federal, estabelece diretrizes gerais da política urbana e dá outras providências.

BRASIL. Lei n. 10.931, de 2 de agosto de 2004. Dispõe sobre o patrimônio de afetação de incorporações imobiliárias, Letra de Crédito Imobiliário, Cédula de Crédito Imobiliário, Cédula de Crédito Bancário, altera o Decreto-Lei no 911, de $1^{\circ}$ de outubro de 1969, as Leis no 4.591, de 16 de dezembro de 1964, nº 4.728, de 14 de julho de 1965, e n 10.406, de 10 de janeiro de 2002, e dá outras providências.

CIDADE DE SÃO PAULO. Lei n. 10.928, de 8 de janeiro de 1991a. Dispõe sobre as condições de habitação dos cortiços e dá outras providências. São Paulo: Prefeitura do Município de São Paulo.

CIDADE DE SÃO PAULO, Lei n. 11.090, de 16 de setembro de 1991b. Estabelece programa de melhorias para a área de influência imediata do Vale do Anhangabaú, cria incentivos e formas para sua implantação, e dá outras providências.

CIDADE DE SÃO PAULO. Lei n. 13.430, de 13 de setembro de 2002. Institui o Plano Diretor Estratégico e o Sistema de Planejamento e Gestão do Desenvolvimento Urbano do Município de São Paulo. São Paulo: Prefeitura do Município de São Paulo.

CIDADE DE SÃO PAULO. Projeto deLei n. 664, de 18 de outubro de 2005. Dispõe sobre a criação de um parque linear elevado no elevado costa e silva, entre as ruas traipu e do lavradio e rua ana cintra, nos distritos da barra funda e santa cecília, subprefeituras da lapa e da sé, e dá outras providências. Prefeitura do Município de São Paulo. 
CIDADE DE SÃO PAULO. Lei n. 16.050, de 31 de julho de 2014. Aprova a Política de Desenvolvimento Urbano e o Plano Diretor Estratégico do Município de São Paulo e revoga a Lei no 13.430/2002. São Paulo: Prefeitura do Município de São Paulo.

CIDADE DE SÃO PAULO. Emenda n. 2712/2014 ao projeto de lei n. 467/2014. Diário Oficial da Cidade de São Paulo, São Paulo, SP, 18 dez. 2014. Seção 59, p. 257.

CIDADE DE SÃO PAULO. Lei n. 16.397 de 9 de março de 2016a. Altera a denominação do logradouro que especifica para Parque Minhocão. São Paulo: Prefeitura do Município de São Paulo.

CIDADE DE SÃO PAULO. Decreto n. 56.901/2016b - Projeto de Intervenção Urbana. 2016a.

CIDADE DE SÃO PAULO. Lei n. 16.833 de 7 de fevereiro de 2018. Cria o Parque Municipal do Minhocão e prevê a desativação gradativa do Elevado João Goulart. São Paulo: Prefeitura do Município de São Paulo. 

